\title{
Avaliação do impacto do lançamento de resíduos gerados na estação de tratamento de água em sistemas de lagoas de estabilização
}

\author{
Alexandre Alves de Oliveira
}

Dissertação apresentada ao Programa de Pós Graduação em Saúde Pública da Faculdade de Saúde Pública da Universidade de São Paulo para obtenção do título de Mestre em Saúde Pública

Área de Concentração: Saúde Ambiental Orientadora: Prof . Dra. Silvana Audrá Cutolo

São Paulo

2005

BibliotecaICIR

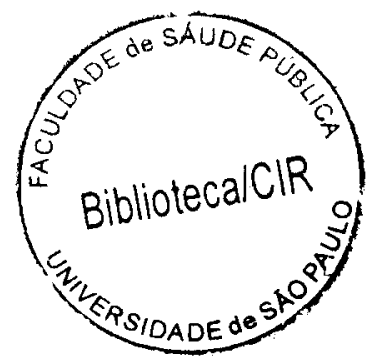


Autorizo, exclusivamente para fins acadêmicos e cientificos, a reprodução total ou parcial desta dissertação, por processos fotocopiadores.

Assinatura:

Data:

4684 22/2006 dV 
“O Futuro pertence àqueles que acreditam na beleza de seus sonhos. " 


\section{AGRADECIMENTOS}

Primeiramente à Deus e aos meus guias espirituais, por toda força, amparo e saúde que me motivam a continuar em busca dos meus objetivos e que acompanham meus passos ao longo de minha vida.

Aos meus pais Sérgio e Deise, pelo incentivo, amor incondicional, confiança e atenção. Vocês são as pessoas mais especiais e maravilhosas que conheço.

À minha esposa Renata, pela compreensão e constante incentivo, sem os quais seria impossivel a conclusão deste trabalho.

Aos meus familiares pelas palavras de carinho, apoio e conforto.

À minha orientadora Dra. Silvana Audrá Cutolo pela orientação, confiança e apoio durante todas as fases deste projeto.

Ao amigo e professor Dr. Roque Passos Piveli do Departamento de Hidráulica da Faculdade Politécnica da USP, pela paciência e orientação no direcionamento e execução deste trabalho.

Ao Dr. Murilo Damato, pela revisão, orientação e sugestões durante o exame de qualificação e pré-banca. 
À contribuição, incentivo, compreensão e apoio do prof Dr. Arlindo Philippi Jr.

À Dra. Maria Aparecida Faustino Pires e Marycel Elena Barboza Cotrim do IPEN, pela confiança e pela oportunidade de meu desenvolvimento profissional.

Ao Dr. Sidney Seckler Ferreira Filho do Departamento de Hidráulica da Faculdade Politécnica da USP, pelas horas de orientação, ajuda e apoio.

Aos colegas: Eng. Jiro Hiroi, Oswaldo Beltrame, Francisco Diniz e demais funcionários da Sabesp de São Lourenço da Serra, pela confiança e paciência nas horas de coleta.

A todos os funcionários da biblioteca, pelo auxílio nas referências e revisões bibliográficas, em especial à: Maria do Carmo $A$. Alvarez, Márcia Regina P. Ribeiro, Antônia do Nascimento, Afra Régia de Lima, Liliane Alessandra da Costa e Gisele Luiza Cano.

As funcionárias Ângela e Marilene Rosa Silva Pereira da Comissão de Pós-graduação/ FSP-USP pelas orientações prestadas.

Aos funcionários do Departamento Saúde Ambiental Nilson Silva Soares e José Etevaldo do Nascimento pelo auxílio na coleta de amostras e ensaios batimétricos. 
As funcionárias do Departamento Saúde Ambiental Maria do Carmo Dória e Francisca Alzira dos Santos e as estagiárias Lícia Natal e Ana Carolina, pelos ensaios e análises das amostras.

A todos os funcionários do Departamento de Saúde Ambiental, em especial Vanda, IIma, Sérgio L. M. Ribeiro, Andrade, Solange Martone Rocha e Célia Pesquero, pelas longas horas de conversa, apoio e contribuições.

A todos os professores da Faculdade de Saúde Pública, em especial ao prof. Dr. Délsio Natal, pelas palavras de incentivo e pela eterna amizade.

Aos amigos da empresa Servsan pelo apoio prestado durante esta nova fase de minha vida e em especial à Samantha Belarmino e ao seu diretor Paulo Afonso Belarmino pela compreensão, confiança e companheirismo.

A todos aqueles que direta ou indiretamente sempre acreditaram no meu trabalho e torceram por mim. 


\section{RESUMO}

Oliveira, AA. Avaliação do impacto do lançamento de resíduos gerados na estação de tratamento de água em sistemas de lagoas de estabilização. São Paulo; 2005 [Dissertação de Mestrado - Faculdade de Saúde Pública da USP].

Objetivo. A disposição de resíduos de ETA em corpos d'água pode causar uma série de problemas ao ambiente aquático. Como alternativa, esses resíduos gerados podem ser dispostos em Estações de Tratamento de Esgotos, sendo transportados em caminhões ou lançados nas redes coletoras. O presente trabalho avalia o impacto do lançamento desses resíduos na Estação de Tratamento de Esgoto do município de São Lourenço da Serra (SP). Métodos. Foram avaliadas as variáveis físicoquímicas e bacteriológicas do esgoto bruto e do efluente das lagoas anaeróbia $\theta$ facultativa, antes $\Theta$ após 0 lançamento desses resíduos. Resultados Durante as duas fases do monitoramento, a análise dos resultados permitiu verificar o excelente desempenho na remoção de material orgânico, com eficiências de remoção de $\mathrm{DBO}_{5,20}$, de $90,5 \%$ na $1^{\mathrm{a}}$ fase e $88,8 \%$ na $2^{\mathrm{a}}$. A eficiência de remoção de nutrientes (nitrogênio e fósforo) apresentou-se dentro dos parâmetros de projeto. Apesar dos altos resultados de remoção de patógenos observados na $1^{\mathrm{a}}$ fase e na $2^{\mathrm{a}}$ fase, 0 efluente final não atendeu os valores exigidos pelo decreto 8468/76 e CONAMA 357/05. Conclusōes. Considerando os resultados experimentais, pode-se verificar que o lançamento dos resíduos gerados na ETA não alterou as características físico-químicas e biológicas do esgoto bruto e não interferiu nos processos biológicos verificados neste tipo de tratamento, mantendo o desempenho da estação dentro dos valores estimados na fase de dimensionamento.

Descritores: Lagoas de Estabilização; Avaliação de desempenho; Avaliação de ETE; Análise de parâmetros físico-químicos e bacteriológicos. 


\section{ABSTRACT}

Oliveira, AA. Evaluation of impact launching of water plant sewages in stabilization lagoons systems. São Paulo; 2005 [Master Degree Thesis Faculdade de Saúde Pública - USP].

Aim. The disposition of water plant sewage in water collections can cause many problems to the aquatic environment. As altemative, this wastes can be disposed in Sewage Treatment Plant (STP), being carried in trucks or launched in sewerages. These works evaluates the impact of these residues that are launching in Sewage Treatment Plant, in São Lourenço da Serra (SP). Methods. The physiochemical and bacteriological characterisitics of the raw wastewater and the effluent of anaerobic and facultative ponds were evaluated, before and after these wastes launching. Results. During the two monitoring phases, the analysis of the results were allowed to verify the excellent performance in the removal of organic material, with efficiencies of BOD $5,20(90,5 \%)$ in $1^{\text {st }}$ phase, and $88,8 \%$ in $2^{\text {nd }}$ phase. The efficiency of nutrients removal (nitrogen and phosphorous) came inside of the project parameters. Despite the high results of pathogens removal observed in first and second phases, the final effluent didn't assist the values demanded by decree 8468/76 and CONAMA 357/05. Conclusion. Considering the experimental results, it can be verified that the launching of generated wastes in water plant did not modify the physiochemical and biological characteristic of the raw wastewater and didn't interfere in biological processes verified in this treatment, keeping the performance of the station inside of the values observed in the project phase.

Descriptors: Stabilization ponds; acting evaluation; STP evaluation; Analysis of physiochemical and bacteriological parameters. 


\section{INDICE}

Agradecimentos

Resumo vi

Abstract vii

Índice viii

Lista de Quadros $\quad$ xii

Lista de Figuras $\quad$ xv

Lista de Tabelas $\quad$ xxi

1. INTRODUÇÃO 1

2. OBJETIVO 6

$2.1 \mathrm{Geral} \quad 6$

2.2. Específicos 6

3. REVISÃO BIBLIOGRÁFICA 7

$\begin{array}{ll}3.1 \text { Generalidades } & 7\end{array}$

3.2 Características da água.

3.2.1 Características físicas 11

3.2.1.1 Turbidez 11

3.2.1.2 Cor 12

3.2.1.3 Sabor e Odor 13

$\begin{array}{ll}3.2 .1 .4 \text { Temperatura } & 14\end{array}$

$\begin{array}{ll}\text { 3.2.1.5 Potencial ZETA } & 15\end{array}$

3.2.2 Características químicas $\quad 17$

$\begin{array}{ll}3.2 .2 .1 \mathrm{pH} & 18\end{array}$

3.2.2.2 Alcalinidade $\quad 19$

$\begin{array}{ll}3.2 .2 .3 \text { Acidez } & 20\end{array}$

$\begin{array}{ll}\text { 3.2.2.4 Dureza } & 20\end{array}$

3.2.2.4 Compostos Orgânicos $\quad 22$

$\begin{array}{ll}\text { 3.2.3 Características biológicas } & 22\end{array}$

3.3 TRATAMENTO DE ÁGUAS DE ABASTECIMENTO 24

$\begin{array}{ll}\text { 3.3.1 Tecnologias de tratamento } & 24\end{array}$ 
3.3.1.1 Tratamento sem coagulação química

3.3.1.2 Tratamento com coagulação química 31

3.3.1.2.1 Filtração direta $\quad 32$

3.3.1.2.1.1 Filtração direta ascendente $\quad 39$

3.3.1.2.1.2 Filtração direta descendente $\quad 41$

3.3.1.2.2 Tratamento em ciclo completo $\quad 43$

3.3.2 Mecanismos de coagulação $\quad 45$

3.3.2.1 Compressão da camada difusa 47

3.3.2.2. Adsorção e neutralização de carga 49

3.3.2.3. Varredura 51

3.3.2.4. Adsorção e formação de pontes 53

4. RESÍDUOS GERADOS NAS ESTAÇÕES DE TRATAMENTO DE ÁGUA 55

4.1 Origem dos lodos $\quad 55$

4.2 Características dos lodos $\quad 60$

4.3 Produção de lodo e balanço de massa 64

5. TRATAMENTO DE ESGOTO

5.1 Organismos presentes no esgoto 75

$\begin{array}{ll}5.2 \text { Lagoas de estabilização } & 77\end{array}$

5.2.1 Histórico 77

5.2.2 Conceito de lagoas de estabilização $\quad 79$

$\begin{array}{ll}\text { 5.2.2.1 Definição } & 79\end{array}$

5.2.2.1.1 Fenômenos naturais incontroláveis $\quad 81$

5.2.2.2.Classificação e princípios biológicos das lagoas de $\quad 82$ estabilização

5.2.2.2.1 Princípios da respiração e fotossíntese. $\quad 82$

5.2.2.2.2 O papel das bactérias $\quad 85$

5.2.2.2.3 O papel das algas $\quad 85$

5.2.2.2.4 Lagoas anaeróbias $\quad 88$

5.2.2.2.5 Lagoas facultativas $\quad 92$

5.2.3 Modelos matemáticos utilizados no dimensionamento de lagoas de $\quad 96$ estabilização. 
5.2.3.1 Modelos empíricos. $\quad 97$

5.2.3.1.1. Lagoas anaeróbias. $\quad 97$

5.2.3.1.1.1 Método da taxa de aplicação volumétrica. $\quad 97$

5.2.3.1.1.2 Método do tempo de detenção hidráulico. 98

$\begin{array}{ll}5.2 .3 .1 .2 . & \text { Lagoas facultativas } \\ & 101\end{array}$

5.2.3.1.2.1 Método da taxa de aplicação superficial $\quad 101$

$\begin{array}{ll}\text { 5.2.3.2 Modelos racionais } & 103\end{array}$

5.2.3.2.1 Modelo proposto por MC GARRY \& PESCOD 104

5.2.3.2.2 Modelo proposto por KAWAI, YANO \& 105

SCHENEIDERMAN

5.2.3.2.3 Modelo proposto por YANEZ 106

5.2.3.2.4 Modelo proposto por CUBILLOS 108

$\begin{array}{ll}\text { 5.2.4 Resíduos gerados nos lagoas de estabilização } & 110\end{array}$

5.2.4.1 Dados e resultados operacionais de lagoas anaeróbias e $\quad 112$ facultativas

5.2.4.2 Produção de lodo em lagoas anaeróbias e facultativas $\quad 115$

5.2.4.2.1 Estimativa da formação de lodo em lagoas $\quad 120$

anaerobias e facultativas

5.2.4.2.1.1 Estimativa através de taxas empíricas $\quad 120$

5.2.4.2.1.2 Estimativa através do modelo de SAQQAR \& $\quad 122$ PESCOD

6. METODOLOGIA $\quad 126$

$\begin{array}{ll}\text { 6.1 Generalidades } & 126\end{array}$

6.2. Caracterização da área de estudo 126

6.3 Descrição da estação de tratamento de água $\quad 129$

6.4 Descrição da estação de tratamento de esgoto 134

$\begin{array}{ll}\text { 6.4.1 Processo de tratamento } & 136\end{array}$

6.5 Pontos de amostragem e coleta das amostras $\quad 138$

6.6 Seções e campanhas batimétricas para determinação da espessura da camada $\quad 140$ de lodo

6.7 Análises e exames laboratoriais 
7.1 Padrões de lançamento de efluentes

7.2 Resultados das características físico-químicas e bacteriológicas do esgoto bruto e efluente das lagoas anaeróbia e facultativa (primeira fase).

\subsubsection{Temperatura}

7.2.2 Potencial hidrogeniônico $(\mathrm{pH})$

7.2.3 Sólidos sedimentáveis

7.2.4 Demanda bioquímica de oxigênio (DBO)

7.2.5 Demanda química de oxigênio (DQO)

7.2.6 Nitrogênio Total Kjedhal (NKT) e Nitrogênio Amoniacal

7.2.7 Fósforo Total

7.2.8 Sólidos em suspensão (SS)

7.2.9 Coliformes totais e coliformes termotolerantes

7.2.10 Estimativa da Produção de Lodo em Lagoas Anaeróbias

7.3. Balanço de massa e avaliação da produção de lodo na ETA.

7.4 Resultados das características físico-químicas e bacteriologicas do esgoto bruto e efluente das lagoas anaeróbia e facultativa (segunda fase).

\subsubsection{Temperatura}

7.4.2 Potencial hidrogeniônico $(\mathrm{pH})$

7.4.3 Demanda bioquímica de oxigênio (DBO)

7.4.4 Demanda química de oxigênio (DQO)

7.4.5 Nitrogênio Total Kjedhal (NKT) e Nitrogênio Amoniacal

7.4.7 Sólidos em suspensão (SS)

7.4.8 Coliformes totais e coliformes termotolerantes

7.4.9 Estimativa da Produção de Lodo em Lagoas Anaeróbias 


\section{LISTA DE QUADROS}

Quadro 3.1 Métodos de Tratamento para garantia da qualidade da água

Quadro 3.2 Alguns Parâmetros físico-químicos e microbiológicos da

Resolução CONAMA 357/05 e Portaria 518 - Ministério da Saúde.

Quadro 3.3 Classificação dos microorganismos em função das

temperaturas de crescimento.

Quadro 3.4 Variação do potencial Zeta em função da dosagem de sulfato de alumínio

Quadro 3.5 Reações físico-químicas de efluentes industriais dependentes de $\mathrm{pH}$.

Quadro 3.6 Reações de dureza temporária e permanente

Quadro 3.7 Distribuição dos tipos de tratamento empregados nas regiōes do Brasil

Quadro 3.8 Classificação dos filtros segundo da velocidade de filtração, taxa de filtração, sentido de fluxo, o meio filtrante e origem da carga do leito Quadro 3.9 Características básicas dos materiais que devem compor os filtros, segundo NB-52.

Quadro 3.10 Tipos de coagulantes e auxiliares de coagulação mais utilizados no tratamento de água.

Quadro 4.1 Porcentagem de lodo gerados nos decantadores e lavagem dos 56 filtros.

Quadro 4.2 Características dos lodos gerados em ETA's.

Quadro 4.3 Características dos lodos gerados através do processo de coagulação com sais de alumínio ou ferro.

Quadro 4.4 Resíduos encontrados durante os processos de tratamento de água.

Quadro 4.5 Valores teóricos da produção de sólidos.

Quadro 4.6 Equações empíricas usadas para o cálculo da quantidade de lodo produzida em uma ETA. 
Quadro 4.7 Parâmetros utilizados para a elaboração de um balanço de massa genérico para um sistema de tratamento de água.

Quadro 5.1 Classificação dos esgotos sanitários domésticos.

Quadro 5.2 Tipos de tratamentos em função eficiência das unidades.

Quadro 5.3 Alguns Grupos de Bactérias Quimiotróficas.

Quadro 5.4 - Gêneros de algas presentes nas lagoas de estabilização do

Estado de São Paulo.

Quadro 5.5 Taxas de aplicação volumétricas para lagoas anaeróbias.

Quadro 5.6 Resultados obtidos com lagoas anaeróbias que tratam despejos domésticos com períodos de detenção inferior a cinco dias.

Quadro 5.7 Porcentagem de redução de $\mathrm{DBO}_{5}$, em função da temperatura da água e do tempo de detenção hidráulico.

Quadro 5.8 Tempos de detenção propostos segundo NBR (1991).

Quadro 5.9 Taxas de aplicação superficial adotadas no Brasil.

Quadro 5.10 Taxas de aplicação superficial para lagoas facultativas, em função das condições ambientais do local da implantação.

Quadro 5.11 Profundidades recomendadas para lagoas facultativas em 103 função das características do esgoto afluente ou das condiçōes climáticas locais.

Quadro 5.12 Correlações entre temperatura média das lagoas facultativas e a temperatura do ar.

Quadro 5.13 Composição química e algumas propriedades típicas de lodo de esgoto.

Quadro 6.1 Características do sistema de esgoto sanitário.

Quadro 6.2 Características das estações elevatórias de esgoto sanitário.

Quadro 6.3 Parâmetros de projeto utilizados no dimensionamento.

Quadro 6.4 Dados de projeto das características físicas das lagoas anaeróbia e facultativa.

Quadro 6.5 Dados de projeto da eficiência total da ETE.

Quadro 6.6 - Características Físico-químicas e bacteriológicas avaliadas nos Pontos de Amostragem e Metodologia Analítica. 
Quadro 6.7 - Equipamentos utilizados na determinação das Características

Físico-químicas e bacteriológicas avaliadas nos Pontos de Amostragem.

Quadro 7.1 Parâmetros utilizados para a elaboração de um balanço de massa genérico para um sistema de tratamento de água. 


\section{LISTA DE FIGURAS}

Figura 3.1 Variação das dimensões das partículas presentes nas águas. 12

$\begin{array}{ll}\text { Figura 3.2 Cor verdadeira em função da absorvância } & 13\end{array}$

$\begin{array}{ll}\text { Figura 3.3 Plano de cisalhamento das partículas. } & 16\end{array}$

Figura 3.4 Classificação e determinação dos sólidos de amostra de água. $\quad 17$

$\begin{array}{ll}\text { Figura 3.5 Relação entre pH e as diversas formas de alcalinidade. } & 19\end{array}$

Figura 3.6 Natureza das impurezas contidas na água bruta 26

$\begin{array}{ll}\text { Figura 3.7 Relação entre várias formas das impurezas e alguns processos } \quad 27 & 27\end{array}$ de tratamento mais utilizados para sua remoção

Figura 3.8 Diversos processos utilizados no tratamento de água bruta, $\quad 28$ comparando os tipos de filtração.

Figura 3.9 Tecnologias de Tratamento sem coagulação química. 29

Figura 3.10 Configurações básicas distintas de filtração direta. 36

Figura 3.11 Fluxograma geral de um sistema de tratamento completo, com $\quad 44$ possíveis variaçōes.

Figura 3.12 Curvas resultantes das energias variando concentração de cargas na camada difusa.

Figura 3.13 Configuração esquemática da dupla camada elétrica.

Figura 3.14 Interações que ocorrem na coagulação, empregando-se como coagulante o sulfato de alumínio.

Figura 3.15 Mecanismos de coagulação por varredura.

Figura 3.16 Reações no mecanismo de adsorção e formação de pontes, utilizando polímeros.

Figura 4.1 Taxa de mortalidade de comunidades bentônicas invertebradas pela adição de lodos de sulfato de alumínio.

Figura 4.2 Esquema do processo de produção de lodo de uma ETA convencional

Figura 4.3 Correlação entre sólidos em suspensão e turbidez para uma 68 fonte de água bruta com baixa cor. 
Figura 4.4 Balanço de massa. Reciclagem integral da água de lavagem sem $\quad 70$ separação de sólidos para a ETA genérica.

Figura 5.1 Composição geral dos despejos domésticos.

Figura 5.2 Processos na digestão anaeróbia (os números referem-se a porcentagens, expressas como DQO).

Figura 5.3 - Variação das Zonas Aeróbias e Anaeróbias.

FIGURA 5.4 Simbiose entre algas e bactérias.

Figura 5.5 Correlação entre fração de nitrogênio amoniacal e taxa de aplicação superficial.

Figura 5.6 Esquema do modelo previsto por SAQQAR e PESCOD.

Figura 6.1 Mapa da UGRHI 11- Ribeira do Iguape e Litoral sul.

Figura 6.2 Mapa do município de São Lourenço da Serra.

Figura 6.3 Esquema da ETA São Lourenço da Serra.

Figura 6.4 Entrada de água bruta.

Figura 6.5 Tanque de coagulação e floculação.

Figura 6.6 Tanque de decantação.

Figura 6.7 Filtros.

Figura 6.8 Tanque de equalização.

Figura 6.9 Volume de água tratada na ETA, utilizado nas lavagens dos filtros 132 e limpeza dos decantadores.

Figura 6.10 Limpeza dos filtros.

Figura 6.11 Concepção do sistema de tratamento da fase sólida gerada na ETA.

Figura 6.12 - Esquema llustrativo da Estação de Tratamento de Esgoto.

Figura 6.13 Coleta de esgoto utilizando balde e corda.

Figura 6.14 Ponto de coleta $n^{\circ} 1$ ( pós caixa de areia).

Figura 6.15 Ponto de coleta $n^{\circ} 2$ (entrada da lagoa facultativa).

Figura 6.16 Ponto de coleta $n^{\circ} 3$ (saída da lagoa facultativa).

Figura 6.17 Pontos de amostragem do lodo e seções batimétricas na lagoa anaeróbia. 
Figura 6.18 Ponto de amostragem da espessura do lodo.

Figura 6.19 Medição da espessura da camada de lodo.

Figura 6.20 Retirada de amostra de lodo.

Figura 7.1 Concentração de DBO do esgoto à entrada e à saída das lagoas anaeróbia e facultativa.

Figura 7.2 Diagramas tipo "boxplot" da concentração de DBO do esgoto à entrada da lagoa.

Figura 7.3 Diagramas tipo "boxplot" da concentração de DBO do esgoto à saída das lagoas anaeróbia e facultativa.

Figura 7.4 Eficiência de remoção de DBO do sistema e da lagoa anaeróbia.

Figura 7.5 Concentração de DQO do esgoto à entrada e à saída das lagoas anaeróbia e facultativa.

Figura 7.6 Diagramas tipo "boxplot" da concentração de DQO do esgoto à entrada da lagoa anaeróbia.

Figura 7.7 Diagramas tipo "boxplot" da concentração de DQO do esgoto à 152 saída das lagoas anaeróbia e facultativa.

Figura 7.8 Eficiência de remoção de DQO do sistema e da lagoa anaeróbia. 153 Figura 7.9 Concentração de Nitrogênio total (NKT) do esgoto à entrada e à 154 saída das lagoas anaeróbia e facultativa.

Figura 7.10 Concentração de Nitrogênio amoniacal do esgoto à entrada e à 154 saída das lagoas anaeróbia e facultativa.

Figura 7.11 Diagramas tipo "boxplot" da concentração de Nitrogênio Total (NKT) do esgoto à entrada e à saída das lagoas anaeróbia e facultativa.

Figura 7.12 Eficiência de remoção de Nitrogênio Total (NKT).

Figura 7.13 Eficiência de remoção de Nitrogênio Amoniacal. 156

Figura 7.14 Concentração de Fósforo Total do esgoto à entrada e à saída das lagoas anaeróbia e facultativa.

Figura 7.15 Diagramas tipo "boxplot" da concentração de Fósforo Total do esgoto à entrada e à saída das lagoas anaeróbia e facultativa.

Figura 7.16 Eficiência de remoção de Fósforo Total.

Figura 7.17 Concentração de SS (mg/L) do esgoto à entrada e à saída das 
lagoas anaeróbia e facultativa.

Figura 7.18 Diagramas tipo "boxplot" da concentração de SS do esgoto à 160 entrada da lagoa anaeróbia.

Figura 7.19 Diagramas tipo "boxplot" da concentração de SS do esgoto à saída das lagoas anaeróbia e facultativa.

Figura 7.20 Eficiência de remoção de SS do sistema e da lagoa anaeróbia.

Figura 7.21 Densidade de coliformes totais do esgoto à entrada e à saída das lagoas anaeróbia e facultativa.

Figura 7.22 Densidade de coliformes termotolerantes do esgoto à entrada e à saída das lagoas anaeróbia e facultativa.

Figura 7.23 Diagramas tipo "boxplot" da densidade de coliformes totais do esgoto à entrada da lagoa anaeróbia.

Figura 7.24 Diagramas tipo "boxplot" da densidade de coliformes totais do esgoto à saída das lagoas anaeróbia e facultativa.

Figura 7.25 Diagramas tipo "boxplot" da densidade de coliformes termotolerantes do esgoto à entrada lagoa anaeróbia.

Figura 7.26 Diagramas tipo "boxplot" da densidade de coliformes termotolerantes do esgoto à saída das lagoas anaeróbia e facultativa.

Figura 7.27 Eficiência de remoção de coliformes totais do sistema e da lagoa anaeróbia.

Figura 7.28 Eficiência de remoção de coliformes termotolerantes do sistema e da lagoa anaeróbia.

Figura 7.29 Espessura da camada de lodo na lagoa anaeróbia

Figura 7.30 Produção média mensal de sólidos no ano de 2004.

Figura 7.31 Balanço de massa da ETA (São Lourenço da Serra).

Figura 7.32 Concentração de DBO do esgoto à entrada e à saída das lagoas anaeróbia e facultativa.

Figura 7.33 Diagramas tipo "boxplot" da concentração de DBO do esgoto à entrada da lagoa anaeróbia.

Figura 7.34 Diagramas tipo "boxplot" da concentração de DBO do esgoto à saída das lagoas anaeróbia e facultativa. 
Figura 7.35 Comparação de eficiências de remoção de DBO do sistema e da lagoa anaeróbia antes e após lançamento do lodo da ETA.

Figura 7.36 Concentração de DQO do esgoto à entrada eà saída das lagoas anaeróbia e facultativa.

Figura 7.37 Diagramas tipo "boxplot" da concentração de DQO do esgoto à entrada da lagoa anaeróbia.

Figura 7.38 Diagramas tipo "boxplot" da concentração de DQO do esgoto à saída das lagoas anaeróbia e facultativa.

Figura 7.39 Comparação de eficiências de remoção de DQO do sistema e da lagoa anaeróbia.

Figura 7.40 Concentração de Nitrogênio total (NKT) do esgoto à entrada e à 179 saída das lagoas anaeróbia e facultativa.

Figura 7.41 Concentração de Nitrogênio amoniacal do esgoto à entrada e à saída das lagoas anaeróbia e facultativa

Figura 7.42 Diagramas tipo "boxplot" da concentração de NKT do esgoto bruto e à saída das lagoas anaeróbia e facultativa.

Figura 7.43 Concentrações médias de NKT e nitrogênio amoniacal à entrada da lagoa anaeróbia.

Figura 7.44 Concentrações médias de NKT e nitrogênio amoniacal à saída da lagoa anaeróbia.

Figura 7.45 Concentrações médias de NKT e nitrogênio amoniacal à saída da lagoa facultativa.

Figura 7.46 Eficiência de remoção de NKT do sistema e da lagoa anaeróbia

Figura 7.47 Eficiência de remoção nitrogênio amoniacal do sistema e da 182 lagoa anaeróbia.

Figura 7.48 Concentração de fósforo total do esgoto à entrada e à saída das lagoas anaeróbia e facultativa.

Figura 7.49 Diagramas tipo "boxplot" da concentração de fósforo total do esgoto à entrada da lagoa anaeróbia.

Figura 7.50 Diagramas tipo "boxplot" da concentração de fósforo total à 184 saída das lagoas anaeróbia e facultativa. 
Figura 7.51 Eficiência média de remoção de fósforo total da lagoa anaeróbia e do sistema.

Figura 7.52 Concentração de sólidos suspensos do esgoto à entrada e à saída das lagoas anaeróbia e facultativa.

Figura 7.53 Diagramas tipo "boxplot" da concentração de sólidos suspensos do esgoto à entrada da lagoa anaeróbia.

Figura 7.54 Diagramas tipo "boxplot" da concentração de sólidos suspensos do esgoto à saída das lagoas anaeróbia e facultativa.

Figura 7.55 Eficiência média de remoção de sólidos suspensos da lagoa anaeróbia e do sistema.

Figura 7.56 Densidade de coliformes totais do esgoto à entrada e à saída das lagoas anaeróbia e facultativa.

Figura 7.57 Densidade de coliformes termotolerantes (NMP/100ml) do esgoto à entrada e à saída das lagoas anaeróbia e facultativa.

Figura 7.58 Diagramas tipo "boxplot" da densidade de coliformes totais do 189 esgoto à entrada da lagoa anaeróbia.

Figura 7.59 Diagramas tipo "boxplot" da densidade de coliformes totais do 190 esgoto à saída das lagoas anaeróbia e facultativa.

Figura 7.60 Diagramas tipo "boxplot" da densidade de coliformes termotolerantes do esgoto à entrada da lagoa anaeróbia.

Figura 7.61 Diagramas tipo "boxplot" da densidade de coliformes

termotolerantes do esgoto à saída das lagoas anaeróbia e facultativa.

Figura 7.62 Eficiência de remoção de coliformes totais do sistema e da lagoa anaeróbia.

Figura 7.63 Eficiência de remoção de coliformes termotolerantes do sistema 192 e da lagoa anaeróbia.

Figura 7.64 Espessura da camada de lodo na lagoa anaeróbia 


\section{LISTA DE TABELAS}

Tabela 3.1 Parâmetros de qualidade de água bruta e de projetos (máximos), sugeridos para tecnologias sem coagulação química.

Tabela 3.2 Principais parâmetros de qualidade da água bruta e de projetos. 40

Tabela 3.3 Principais parâmetros de qualidade e de projetos sugeridos.

Tabela 4.5 Características dos lodos dos decantadores das ETA's da RMSP. 63 Tabela 4.6 Características das águas residuárias de ETA's convencionais, usando $\left[\mathrm{Al}_{2}\left(\mathrm{SO}_{4}\right)_{3}\right]$ como coagulante.

Tabela 5.1 Levantamento de dados operacionais em várias lagoas anaeróbias dos Estados de São Paulo e Paraná.

Tabela 5.2 Lagoas de estabilização de Mairiporã (SP) coleta janeiro de 1976 a março de 1977.

Tabela 5.3 Determinaçāo de série nitrogenada e fosfato solúvel nas lagoas de Mairiporã (SP) - maio 1977

Tabela 5.4 Resultados operacionais lagoas de Mairiporã (SP).

Tabela 5.5 Lagoas de estabilização de Guará (Brasília).

Tabela 5.6 Características e quantidade do lodo produzido em vários sistemas de tratamentos de esgoto

Tabela 5.7 Taxa de produção de lodo.

Tabela 5.8 Características dos lodos acumulados nas lagoas anaeróbias do município de Tatuí.

Tabela 5.9 Características dos lodos acumulados nas lagoas facultativas secundárias do município de Tatuí.

Tabela 5.10 Concentração de sólidos no lodo e taxas de acumulação em diversas lagoas de estabilização.

Tabela 5.11 Estimativa de produção de lodo em diferentes processos de tratamento de esgotos sanitários.

Tabela 7.1 Valores limites estabelecidos para corpo receptor Classe 2 de acordo com Resolução CONAMA 357/05 e Decreto 8468/76, relativos às análises realizadas. 
Tabela 7.2 Valores mínimos, médios e máximos das variáveis analisadas durante monitoramento da ETE.

Tabela 7.3 Resultado de ensaio batimétrico na lagoa anaeróbia.

Tabela 7.4 Variação da turbidez da água bruta, dosagens de coagulantes e produção de sólidos.

Tabela 7.5 Valores mínimos, médios e máximos das variáveis analisadas durante monitoramento da ETE.

Tabela 7.6 Resultado de ensaio batimétrico na lagoa anaeróbia.. 


\section{INTRODUÇÃO}

Ao se estudar a história do homem, MANCUSO (2003) comenta que grande parte da água dos vales fluviais férteis era utilizada pelo homem na irrigação e na agricultura, enquanto somente uma pequena parcela era consumida pela população. Desde então, os conhecimentos sobre a origem das doenças de veiculação hídrica eram limitados e os processos de tratamento de água empregados visavam apenas melhorar o sabor $\theta$ seu aspecto visual.

Ao longo dos anos foram realizados estudos aprofundados sobre as doenças veiculadas pela água e conseqüentemente a forma de se evitálas. Em meados de 1854, após a epidemia ocorrida no distrito de Broad Street, Londres, o médico sanitarista John Snow, através de estudos ligados à epidemiologia, descobriu o modo de transmissão da cólera. Com isso, seu trabalho intitulado "On the Mode of Communication of Cholera" (1865) tomou-se um clássico da literatura médica e da engenharia sanitária (MANCUSO 2003).

Atualmente, mesmo com a implantação de novas tecnologias no tratamento das águas, alguns fatores como: a escassez de mananciais em certas regiōes do Brasil, o aumento da demanda para consumo humano, o elevado grau de poluição e contaminação, em conjunto com as deficiências de saneamento básico, tem cooperado de forma significativa, cerca de $60 \%$, no número de internações hospitalares. (Di BERNARDO 2002).

Segundo BRAGA et al (2003), a Organização Mundial da Saúde (OMS) estima que 25 milhões de pessoas morrem por ano, como conseqüência da qualidade insatisfatória dos recursos hídricos, através de doenças transmitidas pela água (cólera e diarréia), além de outros problemas como metamoglobinemia (elevado teor de nitratos), cáries dentárias (falta de flúor), saturnismo (presença de chumbo). A OMS 
considera também que $70 \%$ da população rural e $25 \%$ da população urbana de países em desenvolvimento não dispõem de abastecimento adequado de água potável.

Portanto, é de fundamental importância que a água, por se tratar de um recurso natural indispensável à vida dos animais $\theta$ vegetais, contenha substâncias essenciais e esteja isenta ou com reduzidas concentrações de outros elementos e microorganismos nocivos à saúde humana e aos organismos que compõem as cadeias alimentares (BRAGA et al 2003).

Um aspecto importante e de certa forma um problema de Saúde Pública citado por Postel (1992), refere-se ao fato de que, mesmo uma parcela da água do planeta ao se transformar em água doce através do processo contínuo de seu ciclo natural e, aproximadamente 40.000 .000 $\mathrm{m}^{3}$ serem transferidos dos oceanos para a terra renovando seu suprimento, o mau uso da água captada, a distribuição desigual de precipitação $\Theta \quad 0$ acelerado crescimento populacional levam aproximadamente 26 países, cerca de 262 milhões de pessoas, a conviverem com escassez deste recurso natural (MANCUSO 2003).

Inúmeras regiões no Brasil também sofrem com a escassez dos recursos hídricos devido principalmente a alterações da qualidade do manancial, ao crescimento populacional, a expansão industrial $\Theta$ a concentração demográfica. Surge então a necessidade da escolha de outros mananciais como fonte de abastecimento ou aplicação de processos de tratamento que garantam os padrões de potabilidade estabelecidos pelo Ministério da Saúde (PROSAB 3 2003).

As Estações de Tratamento de Água (ETA's), ditas convencionais, são constituídas por unidades de coagulação, floculação, sedimentação, filtração seguida de desinfecção. Em diversos países da Europa e nos Estados Unidos os processos utilizados são comparados a processos 
industriais, pois a matéria prima (água bruta), após diversas operações e processos, resulta em um produto final (água tratada), gerando uma certa quantidade de resíduos. Os resíduos (lodo), tanto do ponto de vista quantitativo quanto qualitativo, representam um problema sério para as empresas gerenciadoras $\theta$ são provenientes dos decantadores e águas de lavagem dos filtros que, em função da água bruta e do processo empregado, apresentam características e qualidades variadas (AWWA 1999).

Segundo TSUTIYA (2001), a caracterização do lodo deve estar relacionada à altemativa de disposição final desejada e não apenas na caracterização dos parâmetros estabelecidos pela NBR 10004.

Conforme MONTGOMERY (1985), os resíduos gerados durante o tratamento são calculados a partir do tipo, da dosagem de coagulante utilizada $e$ da qualidade da água bruta. $O$ total de lodo produzido pode ser estimado somando-se a quantidade de sólidos suspensos presentes na água bruta (turbidez) e o lodo gerado pela adição de coagulantes.

Alguns projetos levam em consideração a relação (1:1) entre sólidos em suspensão (SS) e turbidez (TU) pois na análise do balanço de massa, as determinações das concentrações de sólidos presentes nos processos unitários integrantes do sistema de tratamento são trabalhosas (FERNANDES 2002).

GRANDIM (1992) comenta que, ao contrário dos lodos das ETE's, que necessitam estabilização biológica, o lodo das ETA's requerem somente adensamento, condicionamento e desidratação, de tal forma que os custos de transporte e disposição sejam os mais reduzidos possiveis.

Conforme BRATBY (1989), em repouso o lodo apresenta características gelatinosas, tornando-se mais fluido quando 
movimentado, além disso, os resíduos sólidos provenientes de águas brutas com baixa turbidez são compressíveis e resistentes ao adensamento $\theta$ desidratação. Em geral, os lodos das ETA's apresentam baixa quantidade de matéria orgânica biodegradável, relação $\mathrm{DQO} / \mathrm{DBO}_{5}$ da ordem de $15: 1$, sendo a fração de sólidos voláteis cerca de $30 \%$ dos sólidos secos ou totais.

Um aspecto importante quanto ao gerenciamento e disposição final no meio ambiente do lodo da ETA, refere-se ao fato desse material, pela presença de impurezas removidas na água bruta, apresentar grande potencial poluidor, compostos químicos resultantes da incorporação de coagulantes e condicionantes utilizados durante 0 processo de tratamento, contribuindo com aumento da quantidade de sólidos, assoreamento, alterações de cor e turbidez, composição química e demanda de oxigênio (SCALIZE 2003).

A nova tendência das diversas técnicas de tratamento de água consiste em obter um tratamento tão eficiente quanto o convencional, que utiliza decantadores antecedendo o processo de filtração, com significativa redução da quantidade de lodo gerado. A filtração direta é uma dessas técnicas que empregam coagulação química como base para remoção de partículas coloidais. Embora dependa muito da qualidade do manancial, nesse tipo de tratamento são eliminadas unidades de decantação $\theta$, algumas vezes os floculadores, além da redução significativa da quantidade de coagulantes utilizadas em comparação ao tratamento convencional, resultando em menores massas de lodo (REALI 1999).

BAKER (1982) apud TEIXEIRA (1999), revela que a disposição de resíduos contendo alumínio inorgânico com baixos valores de $\mathrm{pH}(<5,5)$ causam uma série de problemas ao ambiente aquático e ao meio ambiente, pois o alumínio empregado no processo pode ser tóxico aos microorganismos aquáticos, bloqueando a respiração dos peixes, além 
de provocar o acúmulo nos leitos dos rios, impossibilitando o crescimento dos organismos que ali se desenvolvem.

Um processo muito aplicado em alguns países da Europa e nos Estados Unidos para minimizar o problema de lançamento do lodo em corpos d água consiste em dispor esses resíduos gerados nas ETA's em Estações de Tratamento de Esgotos (ETE's), sendo transportados em caminhões ou lançados nas redes coletoras (SCALIZE 1999).

Di BERNARDO (2002), ressalta que esta proposta parece ser bastante interessante do ponto de vista econômico, pois haverá redução significativa no custo de operação e manutenção da estação com a simples eliminação de uma unidade de tratamento de resíduos, embora o problema de gerenciamento do lodo estará sendo transferido para a ETE.

Entretanto, CORNWELL \& KOPPERS (1990) alertam que alguns procedimentos devem ser analisados de forma criteriosa antes do lançamento na estação de tratamento de esgoto, principalmente em algumas unidades da estação (digestores de lodo e decantadores primários), que receberão as impurezas dos resíduos da ETA. 


\section{OBJETIVO}

\subsection{Geral}

O presente trabalho tem como objetivo:

D Avaliar o impacto do lançamento dos resíduos gerados na Estação de Tratamento de Água na Estação de Tratamento de Esgoto do município de São Lourenço da Serra (SP).

\subsection{Especificos}

D Realizar revisão bibliográfica em relação ao uso das lagoas como forma de tratamento para comunidades de pequeno e médio porte

$>\quad$ Efetuar o balanço de massa e produção do lodo da estação de tratamento de água

$>$ Caracterizar e comparar segundo parâmetros físicoquímicos e bacteriológicos o esgoto bruto e os efluentes das lagoas anaeróbia e facultativa, antes e após lançamento do lodo gerado na ETA.

$>$ Discutir os resultados obtidos pelas análises em comparação com os parâmetros exigidos pela legislação do Estado de São Paulo (Decreto 8468/76) e legislação federal (CONAMA 357/05). 


\section{REVISÃO BIBLIOGRÁFICA}

\subsection{Generalidades}

Registros relatam que desde 2000 a.C, o ser humano busca melhorar a qualidade da água a ser consumida. Desde aquela época até os dias de hoje, os métodos de tratamento estão constantemente sendo aperfeiçoados levando-se em consideração baixos custos de operação, manutenção e principalmente redução significativa de geração de lodo. Em função das variações sazonais das condições dos mananciais, os padrões de qualidade tem sido obtidos por meio de análises químicas e tecnologias avançadas (AWWA 1990).

O lançamento desordenado de esgoto nos corpos d'água gera conflitos com o uso da água como recurso municipal. Visando assegurar a qualidade e melhorar 0 aproveitamento desse bem natural, seu controle toma-se algo imprescindível. Os mananciais no Brasil são classificados segundo a Resolução do CONAMA $n^{\circ} 357 / 05$, onde são estabelecidos limites dos parâmetros físicos, químicos, biológicos e indicadores específicos para cada classe. Tal medida tem demonstrado ser um instrumento fundamental para garantia da qualidade das águas doces, salobras e salinas (MACÊDO 2004).

O objetivo principal de uma Estação de Tratamento de Água é garantir uma melhor qualidade da água, tomando-a biológica $\Theta$ quimicamente segura para consumo humano e fins higiênicos, com custos de operação e manutenção razoáveis. (AWWA 1990).

Vale ressaltar que o tipo de tratamento exigido depende da natureza e do grau da qualidade do manancial. Por exemplo, se a água captada apresentar padrões aceitáveis de substâncias químicas $\theta$ aspectos físicos favoráveis, um simples processo de desinfecção reduz a contaminação de microorganismos. Caso contrário, se houver cor ou turbidez, serão necessários outros tipos de tratamento como: coagulação 
seguidos de sedimentação, filtração e desinfecção. A seguir no quadro 3.1 são apresentados alguns métodos de tratamento para garantir a qualidade da água (BARNES 1981).

Quadro 3.1 Métodos de Tratamento para garantia da qualidade da água.

\begin{tabular}{|l|l|}
\hline Propriedade & Tratamento Aplicado \\
\hline Cor & $\begin{array}{l}\text { Coagulação e filtração (com carvão ativado) } \\
\text { Oxidação com cloro ou ozônio }\end{array}$ \\
\hline Turbidez & $\begin{array}{l}\text { Coagulação e filtração (coagulação pode ser } \\
\text { dispensada caso a água contenha baixa turbidez) }\end{array}$ \\
\hline Sabor e Odor & $\begin{array}{l}\text { Adsorsão com carvão ativado } \\
\text { Coagulação e filtração } \\
\text { Cloração, Ozonização, Aeração }\end{array}$ \\
\hline pH & $\begin{array}{l}\text { Corrigido com adição de ácido ou } \\
\text { alcali ( } \mathrm{H}_{2} \mathrm{SO}_{4}, \mathrm{HCl}, \mathrm{Na}_{2} \mathrm{CO}_{3}, \mathrm{Ca}(\mathrm{OH})_{2}\end{array}$ \\
\hline Bactérias & $\begin{array}{l}\text { Coliformes menos que } 50 / 100 \mathrm{ml}: \text { desinfecção com } \\
\text { cloro ou ozônio } \\
\text { Coliforme 50-5000/100 ml: coagulação, filtração e } \\
\text { desinfecção } \\
\text { Coliforme > 5000/100 } \mathrm{ml} \quad(\mathrm{E} \text { coli > 2000/100ml): } \\
\text { tratamento avançado }\end{array}$ \\
\hline
\end{tabular}

FONTE: BARNES (1981)

Conforme Di BERNARDO (1993), para se evitar problemas futuros com alterações representativas na qualidade de água, comprometendo assim seu tratamento, é fundamental que antes da escolha do manancial sejam feitos estudos a respeito da bacia hidrográfica, principalmente sobre sua qualidade que pode variar tanto sazonalmente quanto ao longo dos anos $\theta, 0$ autor também ressalta que as tecnologias apresentadas nas literaturas servem apenas como orientação da melhor técnica possível de ser aplicada. Durante seu período de utilização, levantamentos sanitários devem ser executados freqüentemente a fim de se descobrir alterações na qualidade da água. A definição exata do processo empregado depende de ensaios laboratoriais ou projeto piloto. 
Outros fatores além do tecnológico devem ser levados em consideração na implantação do sistema:

$>$ condições sócio-econômicas da comunidade e posição geográfica que ocupa em relação às regiões desenvolvidas em um mesmo país.

$>$ capacidade da estação de tratamento de água;

$>$ disponibilidade de recursos próprios ou capacidade de endividamento através de financiamento;

$>$ mão de obra disponível e qualificada para construção, operação e manutenção da estação;

$>$ disponibilidade de produtos químicos e materiais de construção em regiões próximas ou locais;

$>$ padrão de potabilidade.

Os limites máximos permitidos para inúmeros parâmetros que devem ser respeitados em toda água para consumo podem ser encontrados na Portaria $n^{\circ} 518$, estabelecido pelo Ministério da Saúde em 25 de março de 2004, publicado no Diário Oficial da União em 26 de março de 2004, sob o título Padrão de Potabilidade vigente no Brasil, onde as instituições ou órgãos aos quais se aplicam as normas devem promover as adequações necessárias a seu cumprimento.

Portanto, toda água destinada ao consumo humano deve obedecer aos padrões de potabilidade da Portaria $n^{\circ} 518$ e, fica a cargo das estações de tratamento atingirem os valores considerados, conforme quadro 3.2, onde também são apresentados alguns padrões de qualidade exigidos pela resolução do CONAMA 357/05 em rios classe 1 e classe 2 (AZEVEDO NETTO 1986). 
Quadro 3.2 Parâmetros físico-químicos e microbiológicos da Resolução CONAMA 357/05 e Portaria 518 - Ministério da Saúde.

\begin{tabular}{|c|c|c|c|}
\hline Parâmetro & $\begin{array}{c}\text { Resolução } \\
\text { CONAMA } 357 \\
\text { Classe } 1\end{array}$ & $\begin{array}{c}\text { Resolução } \\
\text { CONAMA } 357 \\
\text { Classe } 2\end{array}$ & $\begin{array}{l}\text { Portaria } 518 \\
\text { Ministério } \\
\text { da Saúde }\end{array}$ \\
\hline Sabor/Odor & $\begin{array}{c}\text { Não } \\
\text { objetável }\end{array}$ & Não objetável & $\begin{array}{c}\text { Não } \\
\text { objetável }\end{array}$ \\
\hline $\mathrm{pH}$ & $6,0-9,0$ & $6,0-9,0$ & $6,0-9,5$ \\
\hline Cor (mg Pt-Co/L e UH) & & 75 & 15 \\
\hline O.D. $\left(\mathrm{mg} \mathrm{O}_{2} / \mathrm{L}\right)$ & $>5$ & $>5$ & - \\
\hline Cor Aparente & & - & 15 \\
\hline Turbidez (UNT) & $<40$ & $<100$ & $<5$ \\
\hline DBO5 (mg O $/ 2 / L)$ & $<3$ & $<5$ & - \\
\hline Cloretos (mg CL'/L) & 250 & 250 & 250 \\
\hline Nitratos (mg N/L) & 10,0 & 10,0 & 10,0 \\
\hline Nitrito (mg N/L) & 1,0 & 1,0 & - \\
\hline Ferro solúvel (mg Fe/L) & 0,3 & 5,0 & 0,3 \\
\hline Manganês (mg/L Mn) & 0,1 & 0,5 & 0,1 \\
\hline $\begin{array}{ll}\text { Sólidos } & \text { dissolvidos } \\
(\mathrm{mg} / \mathrm{L}) & \end{array}$ & 500 & 500 & 1000 \\
\hline Dureza (mg CaCO $3 / \mathrm{L})$ & & - & 500 \\
\hline Sulfatos ( $\mathrm{mg} \mathrm{SO}_{4}{ }^{2-} \mathrm{L}$ ) & 250 & 250 & 250 \\
\hline Cloro residual (mg Cl2/L) & 0,01 & 0,01 & $>0,2$ \\
\hline $\begin{array}{l}\text { Coliformes } \\
\text { termotolerantes } \\
\text { (UFC/100ml) * }\end{array}$ & até 200 & até 1000 & Ausência \\
\hline
\end{tabular}

- Resolução CONAMA 357: deve ser avaliado em $80 \%$ ou mais pelo menos 6 amostras, coletadas durante o período de um ano, com freqũência bimestral.

Portaria 518- M.S.: sistemas que analisam 40 ou mais amostras por més: Ausência em $100 \mathrm{ml}$ em $95 \%$ das amostras examinadas no mês

FONTE: MACÊDO (2004) 


\subsection{Características da água.}

\subsubsection{Características físicas.}

Embora tenham pouca importância do ponto de vista sanitário, as características físicas: cor, turbidez, sabor e odor, temperatura e condutividade elétrica, podem ser determinantes na escolha do tratamento (DI BERNARDO 2002).

\subsubsection{Turbidez}

A turbidez está relacionada à presença de partículas em suspensão e em estado coloidal, provocando difusão $\Theta$ absorção, alterando assim a penetração da luz. Pode ser causada por microorganismos, silte, argila, areia fina em suspensão entre outros, sendo mais difíceis de serem removidas nas ETA's as partículas de menor tamanho com reduzida densidade específica e baixa velocidade de sedimentação. As partículas de maiores dimensões, ao contrário, ao se sedimentarem formam bancos de lodo, criando condições para geração de gás metano e gás carbônico, além de outros gases como: o sulfídrico e o nitrogênio gasoso através do processo de digestão anaeróbia.

Segundo Di BERNARDO (2002), maior será a eficiência da desinfecção, quanto menor for a turbidez da água a ser tratada na ETA. Embora possam ocorrer valores idênticos de turbidez com variações no número $\Theta$ tamanho das partículas, são preferidas as de menores dimensões para garantia de uma melhor desinfecção.

A seguir na Figura 3.1 pode ser observada a variação das dimensões das partículas presentes na água 


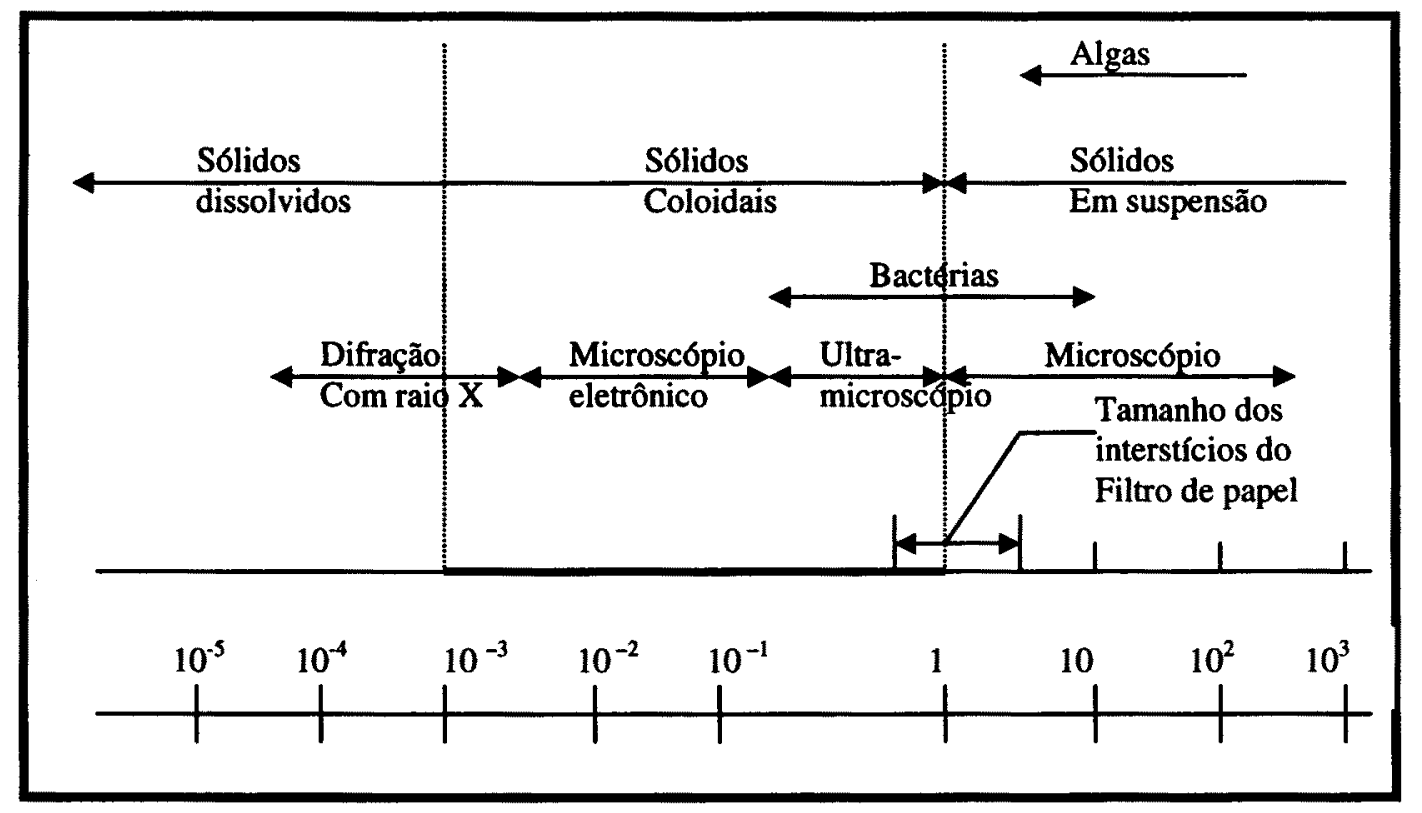

Figura 3.1 Variação das dimensões das partículas presentes nas águas.

FONTE: DI BERNARDO (2002)

\subsubsection{Cor}

A quantificação da cor, do ponto de vista sanitário, é de extrema importância uma vez que, ao entrarem em contato com cloro livre no processo de desinfecção, as substâncias húmicas, que originam cor nas águas através da decomposição de plantas $e$ animais, são as precursoras da formação de trialometanos e organoclorados.

Segundo BRANCO (1991), a cor da água é resultado do processo de decomposição que ocorre no meio ambiente, por esse motivo as águas superficiais estão mais sujeitas a terem cor do que as águas subterrâneas. Alguns íons metálicos como ferro e manganês, plâncton, macrófitas e despejos industriais podem produzir cor nas águas. A partir da centrifugação por $30 \mathrm{~min}$., com rotação de $3.000 \mathrm{~mm}$, ou de água filtrada em membrana de $\mathbf{4 5}$ micrômetro utilizando-se o sobrenadante da amostra de água, obtém-se a cor verdadeira, causada por material dissolvido e colóides. Já a cor dita aparente, pois é como o homem a vê, é resultado da reflexão e dispersão da luz nas partículas em suspensão, nas partículas coloidais e microorganismos, responsáveis pela turbidez . 
De acordo com Di BERNARDO (1993), as substâncias húmicas, geralmente compostas por ácidos húmico e fúlvico em função do seu pH, interferem na medida da cor, pois as dimensões de suas moléculas variam com o pH e com o grau de polimerização (entre 3,5 e 10 ๆm) e, como pode ser visto na figura 3.2 (relação cor verdadeira x absorvância), quanto menor o $\mathrm{pH}$, maior o valor da cor.

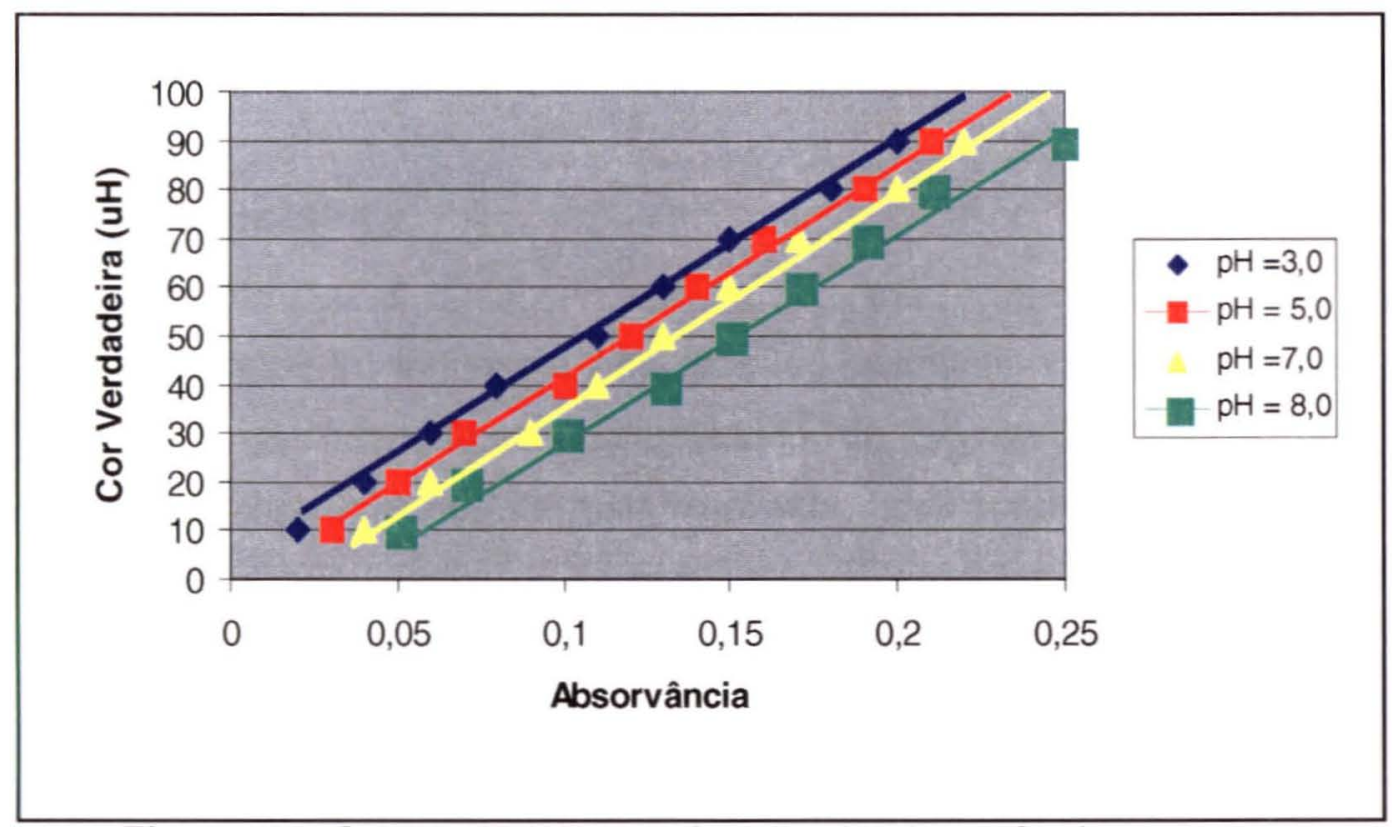

Figura 3.2 Cor verdadeira em função da absorvância

FONTE: DI BERNARDO (2002)

\subsubsection{Sabor e Odor}

As principais fontes geradoras de sabor e odor nas águas são resultantes: da decomposição da matéria orgânica, despejos industriais e atividades biológicas dos microorganismos. Conforme BRANCO (1986), os ácidos graxos presentes nas células das algas são os responsáveis por causar sabor e odor nas águas de abastecimento.

Ainda segundo o autor, a quantificação e deteç̧ão dessas duas propriedades variam muito de indivíduo para indivíduo, dependendo 
exclusivamente da sensibilidade de cada ser humano e do tempo de exposição que tende a diminuir com o tempo.

PIVELI (1996), cita que águas eutrofizadas onde ocorrem florações de algas, devido à presença de grandes quantidades de macronutrientes, quando liberados de compostos orgânicos biodegradáveis manifestam sabor $\Theta$ odor. Como processo de remoção, podem ser empregados: aeração, aplicação de técnicas oxidativas (cloro, peróxido de hidrogênio e ozonização), além do método de adsorção em carvão ativado granular ou em pó.

\subsubsection{Temperatura}

A temperatura influencia nas reações químicas e biológicas, na eficiência na desinfecção, na solubilidade de gases dissolvidos, no desempenho das unidades de mistura rápida, floculação, decantação e filtração. Com o aumento da temperatura, a solubilidade dos gases diminui $\theta$ a dos sais minerais aumenta, interferindo diretamente no crescimento dos microorganismos $\theta$, como pode ser observado no Quadro 3.3, cada microorganismo possui uma faixa ideal de temperatura (BRANCO 1991).

Quadro 3.3 Classificação dos microorganismos em função das temperaturas de crescimento.

\begin{tabular}{|l|c|c|c|}
\hline \multirow{2}{*}{ Grupo } & \multicolumn{3}{|c|}{ Temperatura $\left({ }^{\circ} \mathrm{C}\right)$} \\
\cline { 2 - 4 } & Mínima & Ótima & Máxima \\
\hline Termófilos & $40-45$ & $55-75$ & $60-90$ \\
\hline Mesófilos & $5-15$ & $30-45$ & $35-47$ \\
\hline Psicrófilos & $-5 \mathrm{a}+5$ & $12-15$ & $15-20$ \\
\hline Psicrotróficos & $-5 \mathrm{a}+5$ & $25-30$ & $30-35$ \\
\hline
\end{tabular}

FONTE: ICMSF (1980) 
BABITT, DOLAND E CLEASBY (1976), mencionam que a faixa ideal de temperatura da água para consumo humano situa-se entre 4,4 a $10^{\circ} \mathrm{C}$, tornando-se menos aceitável a valores superiores a $10^{\circ} \mathrm{C}$.

\subsubsection{Potencial ZETA}

É um parâmetro bastante empregado na avaliação da estabilidade e tendência à floculação dos colóides. A medida do potencial zeta corresponde à diferença de potencial entre a camada de íons que circundam a partícula e o ponto onde existam concentrações iguais de ânions e cátions.

De acordo com FERREIRA FILHO (1993), existe uma relação direta do valor do potencial zeta com a velocidade que a partícula coloidal se desloca sob ação de um campo eletrostático. Esta velocidade recebe o nome de velocidade eletroforética.

No Quadro 3.4 são apresentadas variações do potencial zeta em função da dosagem de coagulantes, resultante de ensaios de coagulação realizados por DI BERNARDO (1993) utilizando o sulfato de alumínio PA e água bruta com as seguintes características: turbidez $=10$ $\mathrm{UT}$, alcalinidade total $10 \mathrm{mg} / \mathrm{L}$ de $\mathrm{CaCO}_{3}, \mathrm{pH}=6,7$, potencial zeta $=-16,3$ $\mathrm{mV}$. O autor chegou a conclusão que a coagulação ocorreu por neutralização de cargas das impurezas, uma vez que houve reversão de cargas quando se utilizou dosagem de 6,0 mg/L.

Segundo YOKOSAWA (1994) apud PAVANELLI (2001), o potencial zeta depende do $\mathrm{pH}$ do meio e da espessura da dupla camada elétrica resultante da concentração de íons adsonvidos e da força iônica da suspensão. Dessa forma, se as partículas tiverem cargas resultantes próximas a nula e com a transferência do movimento browniano das partículas ao colóide ocorrerá a aglomeração das partículas e conseqüentemente formação de flocos. Entretanto, se as partículas 
possuírem carga alta, estas são repelidas umas das outras e o colóide toma-se estável.

Quadro 3.4 Variação do potencial Zeta em função da dosagem de sulfato de alumínio

\begin{tabular}{|c|c|}
\hline Dosagem de sulfato de alumínio & Potencial Zeta $(\mathbf{m V})$ \\
\hline 0 & $-16,1$ \\
\hline 2 & $-12,7$ \\
\hline 4 & $-3,0$ \\
\hline 6 & $+3,6$ \\
\hline
\end{tabular}

FONTE: DI BERNARDO (2002)

A figura 3.3 apresenta o plano de cisalhamento, onde geralmente a uma certa distância da superfície da partícula se inicia a camada difusa.

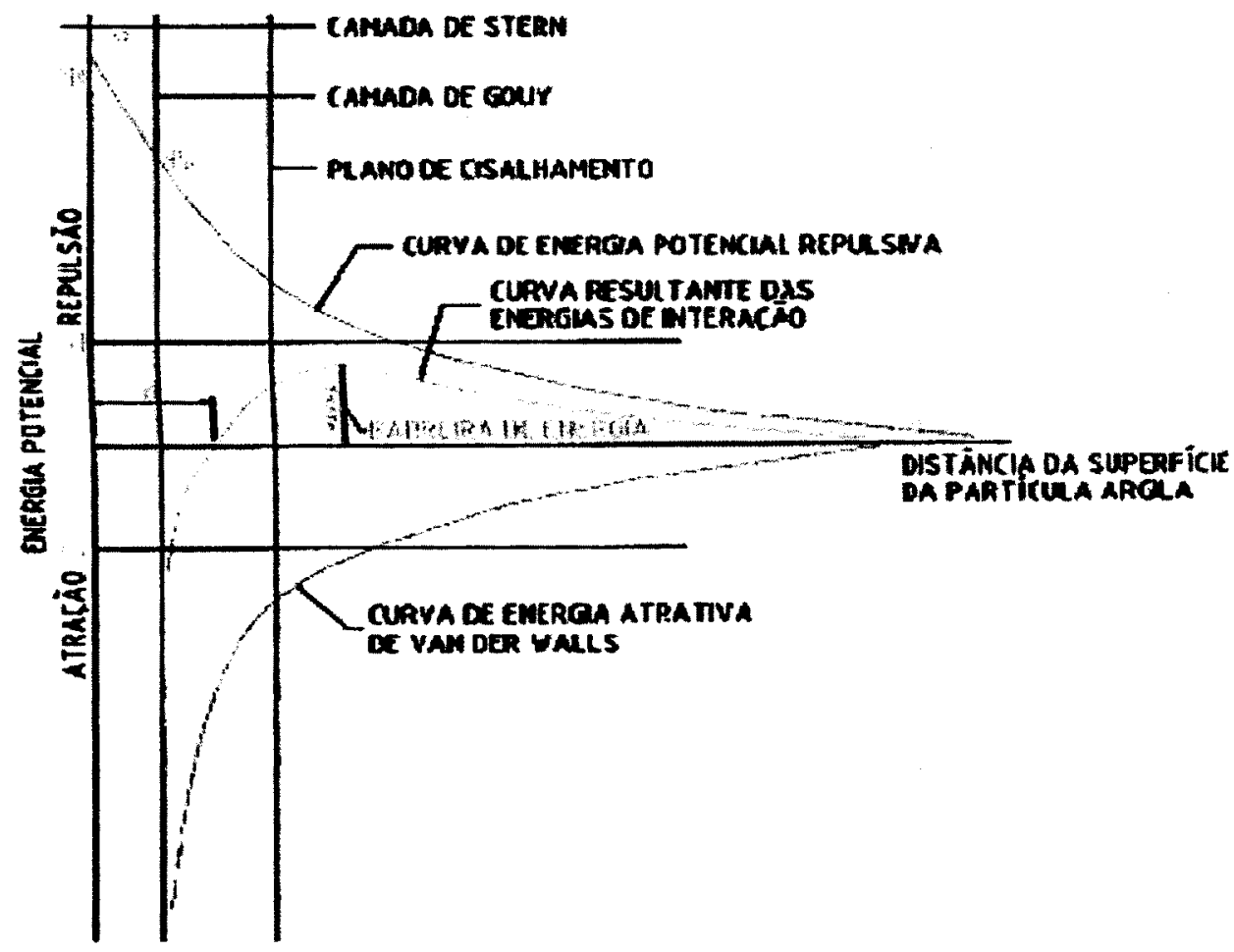

Figura 3.3 Plano de cisalhamento das partículas.

FONTE: Di BERNARDO (1993) 


\subsubsection{Características químicas}

BRANCO (1991) considera os parâmetros químicos como um dos mais importantes na caracterização da qualidade de uma água, pois permitem:

$>$ através dos íons, classificar a água por seu conteúdo natural;

$>$ determinar a origem dos poluentes e seu grau de contaminação;

$>$ identificar possíveis fontes e caracterizar picos de concentração de poluentes tóxicos;

$>$ avaliar o equilíbrio bioquímico, fundamental para manutenção da vida aquática e suas necessidades nutricionais.

A figura 3.4 apresenta a classificação e determinação dos sólidos de amostra de água

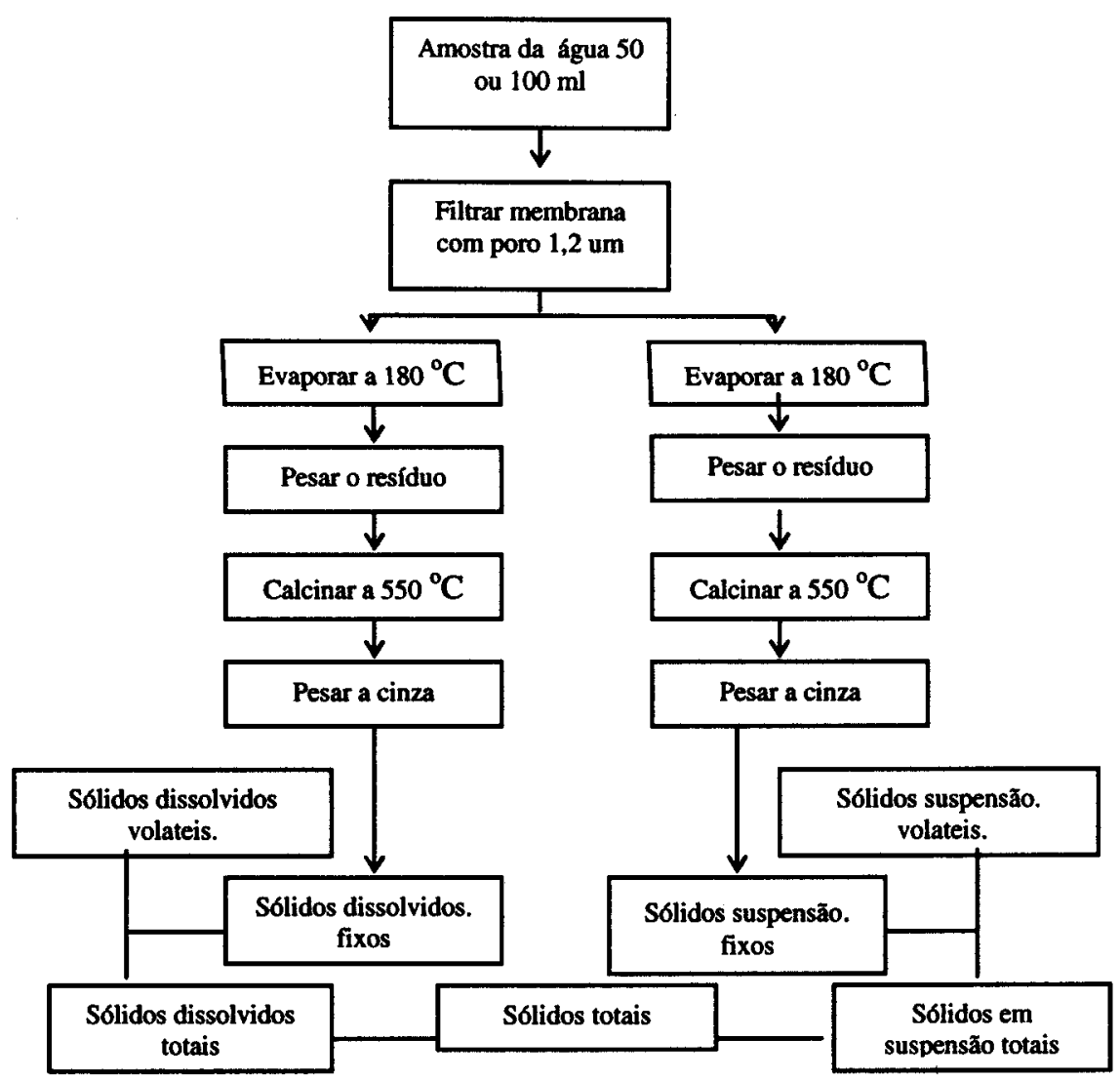

Figura 3.4 Classificação e determinação dos sólidos de amostra de água.

FONTE: MACEDO (2004) 


\subsubsection{1 pH}

Trata-se de importante parâmetro em vários estudos do saneamento ambiental. Utilizado para expressar a acidez de uma solução, representa a atividade do íon hidrogênio na água, na forma de logaritmo, resultante inicialmente da dissociação da molécula da água e acrescida pelo hidrogênio proveniente de outras fontes como: efluentes industriais, dissociação de ácidos orgânicos e outras substâncias que apresentam reação ácida com a água (PIVELI 1996).

Diversas etapas do tratamento dependem dos valores de $\mathrm{pH}$, principalmente nas fases de coagulação e floculação, pois existe uma condição de "pH ótimo", onde as partículas coloidais possuem uma menor quantidade de carga eletrostática superficial, otimizando a floculação. É um importante padrão de potabilidade e, segundo Portaria 518 do Ministério da Saúde, para águas de abastecimento público seu valor deve situar-se entre 6,5 e 8,0.

No Quadro 3.5 são apresentadas reações físico-químicas de efluentes industriais dependentes de $\mathrm{pH}$.

Quadro 3.5 Reações físico-químicas de efluentes industriais dependentes de $\mathrm{pH}$.

\begin{tabular}{|l|c|}
\hline \multicolumn{1}{|c|}{ Reações } & pH \\
\hline Precipitação química de metais pesados & Elevado \\
\hline Oxidação química de cianeto & Elevado \\
\hline Redução de cromo hexavalente a forma trivalente & Baixo \\
\hline Oxidação química de fenóis & Baixo \\
\hline $\begin{array}{l}\text { Quebra de emulsões oleosas mediante } \\
\text { acidificação }\end{array}$ & Elevado \\
\hline Arraste da amônia convertida à forma gasosa & Elevado \\
\hline
\end{tabular}

FONTE: adaptado PIVELI (1996) 


\subsubsection{Alcalinidade}

A alcalinidade pode ser definida como a capacidade da água de neutralizar ácidos, ou seja, reagir quantitativamente com um ácido forte até um valor definido de pH. Devido à atuação ácida dos coagulantes em soluções, a alcalinidade é importante no processo de coagulação e ótimo indicador de coagulante a ser empregado o tratamento de água. Se a alcalinidade da água for alta, provavelmente o sulfato de alumínio não é o coagulante indicado (PAVANELLI 2001).

Nas águas naturais, em função do $\mathrm{pH}$, podem ser encontradas três tipos de alcalinidade: a hidróxido $\left(\mathrm{OH}^{-}\right)$, a carbonato $\left(\mathrm{CO}_{3}{ }^{-}\right)$e a bicarbonato $\left(\mathrm{HCO}_{3}{ }^{-}\right)$, como mostra a Figura 3.5. Entretanto, somente duas formas de alcalinidade podem estar presentes simultaneamente numa mesma amostra, pois haveria reação entre hidróxidos e bicarbonatos, levando a formação de carbonatos segundo a reação abaixo (MACÊDO, 2004).

$$
\mathrm{OH}^{-}+\mathrm{HCO}_{3}^{-} \longrightarrow \mathrm{H} 2 \mathrm{O}+\mathrm{CO}_{3}^{-2}
$$

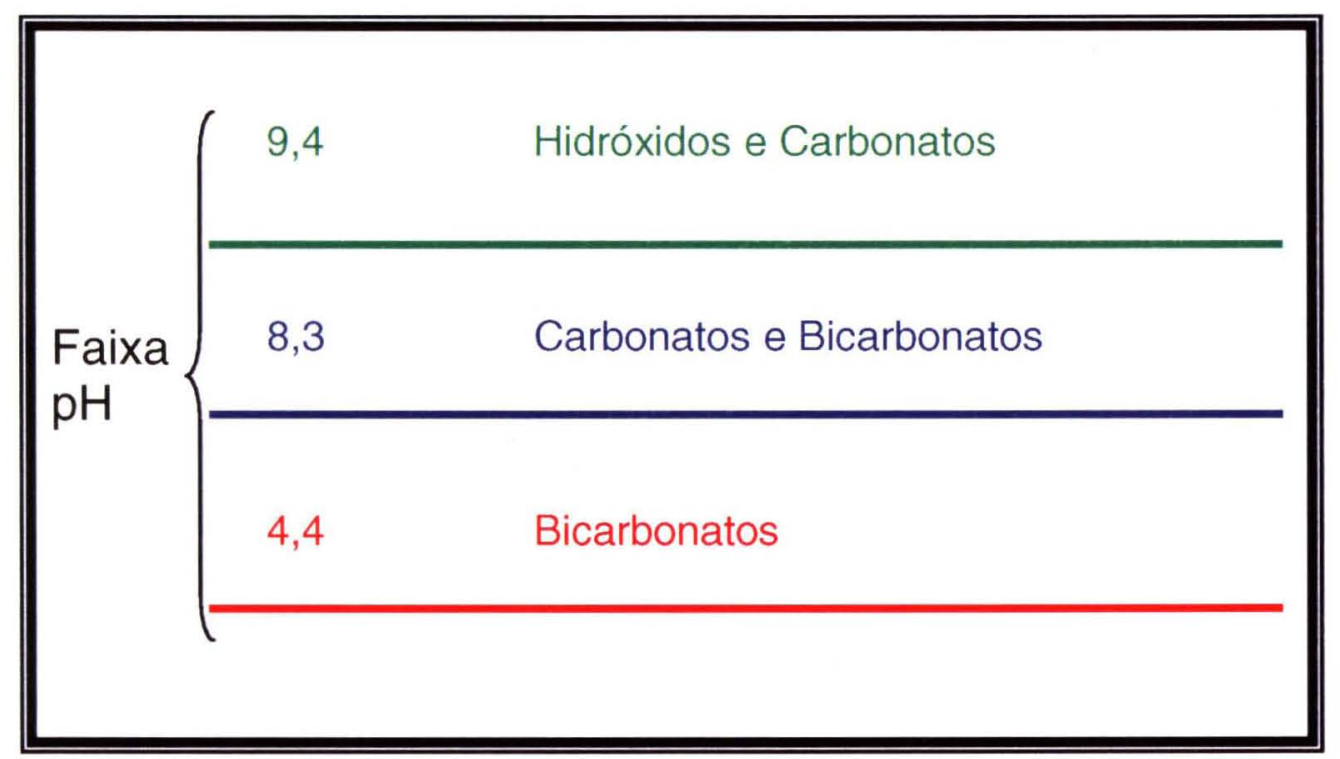

Figura 3.5 Relação entre $\mathrm{pH}$ e as diversas formas de alcalinidade.

FONTE: adaptado MACÊDO (2004) 


\subsubsection{Acidez}

A acidez da água pode ser definida segundo PIVELI (1996), como a capacidade de reagir quantitativamente com uma base forte até um valor definido de $\mathrm{pH}$, devido à presença de ácidos fortes, ácidos fracos, e alguns sais de características ácidas (cloreto férrico, sulfato de alumínio.)

Como nas águas naturais dificilmente são encontrados ácidos fortes, a acidez de uma água ocorre pela dissolução do $\mathrm{CO}_{2}$ presente na faixa de valores de $\mathrm{pH}$ entre 4,5 e 8,3 (DI BERNARDO 2002).

O gás carbônico é um componente natural das águas que, quando dissolvido, leva a formação de acidez carbônica segundo reação mostrada abaixo.

$$
\mathrm{CO}_{2}+\mathrm{H}_{2} \mathrm{O} \longrightarrow \mathrm{H}_{2} \mathrm{CO}_{3}
$$

Já a acidez mineral é resultante da oxidação das sulfobactérias ou pela hidrólise de sais minerais de metais presentes nos despejos industriais, materiais orgânicos ou sintéticos. Do ponto de vista sanitário, a acidez tem pouco significado, sendo importante parâmetro vinculado a problemas de corrosão.

\subsubsection{Dureza}

Definida como a medida da capacidade de precipitar sabão, a dureza de uma água é expressa em termos de quantidade equivalente de $\mathrm{CaCO}_{3}$. Causada pela presença de íons metálicos (cálcio(Ca $\left.{ }^{2+}\right)$ e magnésio $\left(\mathrm{Mg}^{2+}\right)$ ), geralmente associados ao ion sulfato, além de outros cátions que conferem dureza às águas porém em menor grau, por exemplo: ferro e manganês ( $\mathrm{Fe}^{2+}$ e $\mathrm{Mn}^{2+}$ associado ao nitrato), estrôncio $\left(\mathrm{Sr}^{2+}\right.$ associado ao cloreto). 
Di BERNARDO (2002), cita que alguns estudos relacionam a dureza da água com incidência de doenças de problemas cardiovasculares e com aumento do teor do colesterol. Do ponto de vista hidráulico, a dureza das águas está associada a incrustações em sistemas de água quente, causando sérios problemas nos aquecedores.

A dureza de uma água pode ser classificada ainda quanto à associação a íons positivos e negativos. Quanto ao cátion associado, a dureza é classificada como dureza ao cálcio $\theta$ dureza ao magnésio $\theta$, dureza total, resultante da soma da dureza de ambos citados acima, geralmente expressa em $\mathrm{mg} / \mathrm{L} \mathrm{de} \mathrm{CaCO}_{3}$. Quanto ao ânion associado, a dureza é classificada como temporária. Neste caso, o cálcio e o magnésio encontram-se associados a bicarbonatos que, pela ação do calor ou reação com substâncias alcalinas, provocam formação de carbonatos, formando incrustações ao se precipitarem. A dureza permanente resulta da presença de sulfatos de cloretos de cálcio e/ou magnésio em solução, neste caso a ação do calor não influencia sobre esse tipo de dureza, a seguir na quadro 3.6 são apresentadas as reações de dureza permanente e temporária (SHREVE e BRINK JR 1977).

Quadro 3.6 Reações de dureza temporária e permanente.

\begin{tabular}{|c|}
\hline Reaçōes de dureza temporária \\
\hline $\mathrm{Ca}\left(\mathrm{HCO}_{3}\right)_{2}$ (solúvel)+ calor $\longrightarrow \mathrm{CaCO}_{3}+\mathrm{H}_{2} \mathrm{O}+\mathrm{CO}_{2}$ \\
\hline $\mathrm{Mg}\left(\mathrm{HCO}_{3}\right)_{2}$ (solüvel) + calor $\longrightarrow \mathrm{MgCO}_{3}+\mathrm{H}_{2} \mathrm{O}+\mathrm{CO}_{2}$ \\
\hline$\longrightarrow \quad \mathrm{Mg}(\mathrm{OH})_{2}+\mathrm{CO}_{2}$ \\
\hline$\Longrightarrow \quad \mathrm{CaCO}_{3}+\mathrm{Na}_{2} \mathrm{CO}_{3}+2 \mathrm{H}_{2} \mathrm{O}$ \\
\hline $\mathrm{MgCO}_{3}+\mathrm{Na}_{2} \mathrm{CO}_{3}+2 \mathrm{H}_{2} \mathrm{O}$ \\
\hline Reações de dureza permanente \\
\hline$\Longrightarrow \mathrm{CaCO}_{3}+2 \mathrm{NaCl}$ \\
\hline$\longrightarrow \mathrm{Mg}(\mathrm{OH})_{2}+\mathrm{CaCl}_{2}$ \\
\hline $\mathrm{CaSO}_{4}+\mathrm{Na}_{2} \mathrm{CO}_{3} \longrightarrow \mathrm{CaCO}_{3}+\mathrm{Na}_{2} \mathrm{SO}_{4}$ \\
\hline $\mathrm{MgSO}_{4}+\mathrm{Na}_{2} \mathrm{CO}_{3}+\mathrm{Ca}(\mathrm{OH})_{2} \longrightarrow \mathrm{Mg}(\mathrm{OH})_{2}+\mathrm{CaCO}_{3}+\mathrm{Na}_{2} \mathrm{SO}_{4}$ \\
\hline
\end{tabular}

FONTE: adaptado SHREVE e BRINK JR (1977). 


\subsubsection{Compostos Orgânicos}

Os compostos orgânicos surgem nas águas a partir de três fontes: a primeira pela presença substâncias húmicas, microrganismos e seus metabólitos e hidrocarbonetos aromáticos a partir da quebra de moléculas de substâncias orgânicas naturais, a segunda como resultado das atividades antrópicas, com lançamento de despejos domésticos ou industriais tratados ou não, escoamento superficial urbano ou rural $e$, por último, nas reações que ocorrem em ETA's, podendo haver formação de trialometanos e halo-acetonitrilas (Di BERNARDO 1993).

Segundo Di BERNARDO (2002), para uma rápida e precisa determinação da concentração de compostos orgânicos impostos pela legislação, a exigência de equipamentos sofisticados e operadores especializados representam sérias dificuldades para órgãos de controle de poluição e operadores de ETA's. Em mananciais sujeitos a contaminação de compostos nocivos à população, devem ser empregados carvão ativado no tratamento $\Theta$ evitar a captação da água de superfície e do lodo sedimentado no fundo, pois podem apresentar elevados compostos orgânicos indesejáveis.

\subsubsection{Características biológicas}

Somente por meio de exames bacteriológicos e hidrobiológicos, são conhecidas as características sanitárias da água. Em geral esses exames visam identificar e qualificar organismos microscópicos como: algas, protozoários, rotíferos, vermes e larvas de insetos. Esses exames auxiliam ainda no controle de poluição das águas e na prevenção do desenvolvimento de organismos indesejáveis no processo de tratamento de água (BRANCO 1986).

Ainda segundo o autor, um dos indicadores biológicos de poluição bastante utilizado são os coliformes, que demonstram a contaminação 
recente das águas por excretas de origem humana e animal, sendo que apenas os coliformes termotolerantes indicam a poluição por excretas de animais homeotermos.

Embora não haja relação entre coliformes $\theta$ organismos patogênicos, existe uma correlação baseada na probabilidade de que, quanto maior o número de coliformes, maior o número de organismos patogênicos (Di BERNARDO 2002).

Este autor ressalta ainda que, cuidados especiais na escolha do tratamento das águas de abastecimento devem ser levados em consideração na presença de coliformes totais ou termotolerantes, por existir uma relação que, quanto menor a turbidez da água filtrada, menor o número de coliformes, contribuindo assim no processo de desinfecção. E a presença de algas nas ETA's causa sérios problemas aos sistemas, pois ao flotarem nos decantadores são carreadas aos filtros, obstruindoos após algumas horas. 


\subsection{TRATAMENTO DE ÁGUAS DE ABASTECIMENTO}

\subsubsection{Tecnologias de tratamento}

Os órgãos de abastecimento público devem sempre fornecer água de boa qualidade, efetuando análises e exames periódicos das águas captadas e distribuídas, que revelarão a necessidade de intervenções de qualquer processo corretivo (AZEVEDO NETTO 1987).

KAWAURA (2000), estabelece que as altemativas de processos de tratamento são fundamentadas pelas características da água bruta captada e também pela qualidade e destino final da água tratada.

AZEVEDO NETTO (1987), considera que a localização da ETA entre o ponto de captação $\theta$ a área a ser distribuída, assim como a seleção das altemativas e critérios de projeto são influenciados pelos seguintes fatores:

$>$ ser eficiente, atendendo os padrões da legislação estadual e federal, $e$ as necessidades da população

$>$ facilidade de acesso e transporte;

$>$ disponibilidade de energia elétrica;

$>$ facilidades para afastamento de águas de lavagem;

$>$ disponibilidade de terreno com área suficiente para ampliações futuras;

$>$ cota topográfica favorável para adução;

$>$ custo razoável do terreno;

$>$ capacidade de alterações do projeto, em caso de mudanças de qualidade do manancial e/ou padrões da legislação;

$>$ custos razoáveis de operação e manutenção;

$>$ apresentar facilidades para reparos e reposição de peças e produtos químicos. 
De um modo geral, a estação de tratamento de água de abastecimento pode ser definida como conjunto de processos e operações, com o objetivo de fornecer água tratada que não ofereça riscos à população e atenda aos padrões de potabilidade dos órgãos ambientais por intermédio da legislação, no Brasil, especificada pela Portaria 518 do Ministério da Saúde que entrou em vigor em 2004, substituindo a Portaria 1469 de 2002.

Segundo dados do IBGE (2002), na Pesquisa Nacional de Saneamento Básico, as tecnologias de tratamento são classificadas em: convencionais (coagulação, floculação, decantação e filtração), não convencionais (incluindo filtração direta ascendente e descendente, dupla filtração e filtração lenta). A simples desinfecção é aplicada somente para águas subterrâneas que apresentam condições naturais sanitárias seguras. (Di BERNARDO 2003)

No quadro 3.7 é apresentada a distribuição dos tipos de tratamentos empregados nas regiões do Brasil

Quadro 3.7 Distribuição dos tipos de tratamento empregados nas regiões do Brasil

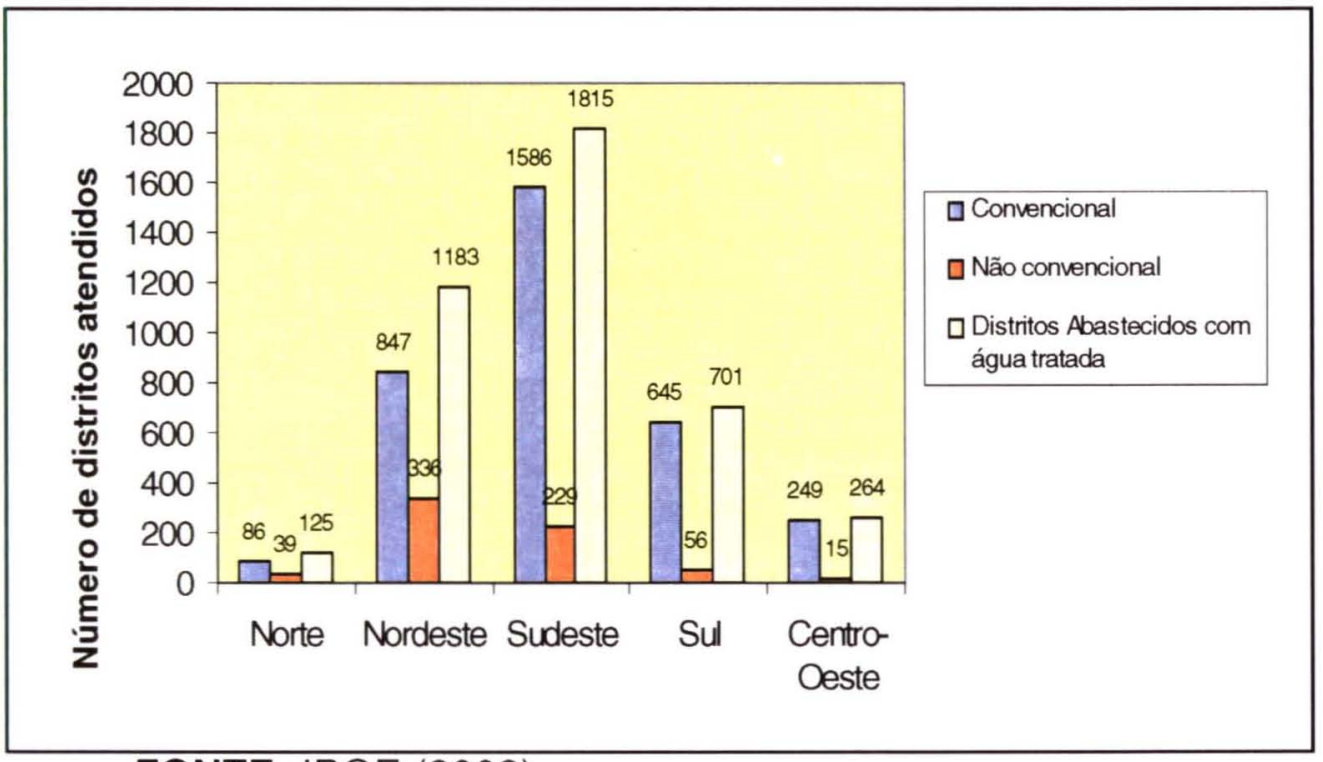

FONTE: IBGE (2002) 
Todo projeto deve ser precedido por experiências e ensaios de laboratório, pois auxiliam na escolha da técnica a ser adotada, reduzem custos, oferecem maior segurança às soluções propostas. No caso de projetos de grandes estações de tratamento, em que não exista nenhum tipo de avaliação da água a ser tratada, devem ser utilizados projetos piloto, que em escala adequada, reproduzam os processos $\theta$ as unidades de tratamento que serão empregadas, possibilitando assim, a obtenção de parâmetros mais vantajosos e conseqũentemente melhores soluções para o tratamento (AZEVEDO NETTO 1987).

No processo de escolha de tratamento, é de grande importância o conhecimento das formas físicas, químicas e biológicas das impurezas a serem removidas. $O$ tratamento adequado na remoção das impurezas são classificados em: processos químicos, físicos e biológicos, considerando-se o tamanho das partículas A seguir na figura 3.6 é apresentada a classificação das impurezas contidas na água bruta $\theta$, na figura 3.7, a relação entre várias formas das impurezas $\theta$ alguns processos de tratamento mais utilizados para sua remoção. (BARNES et al 1981).

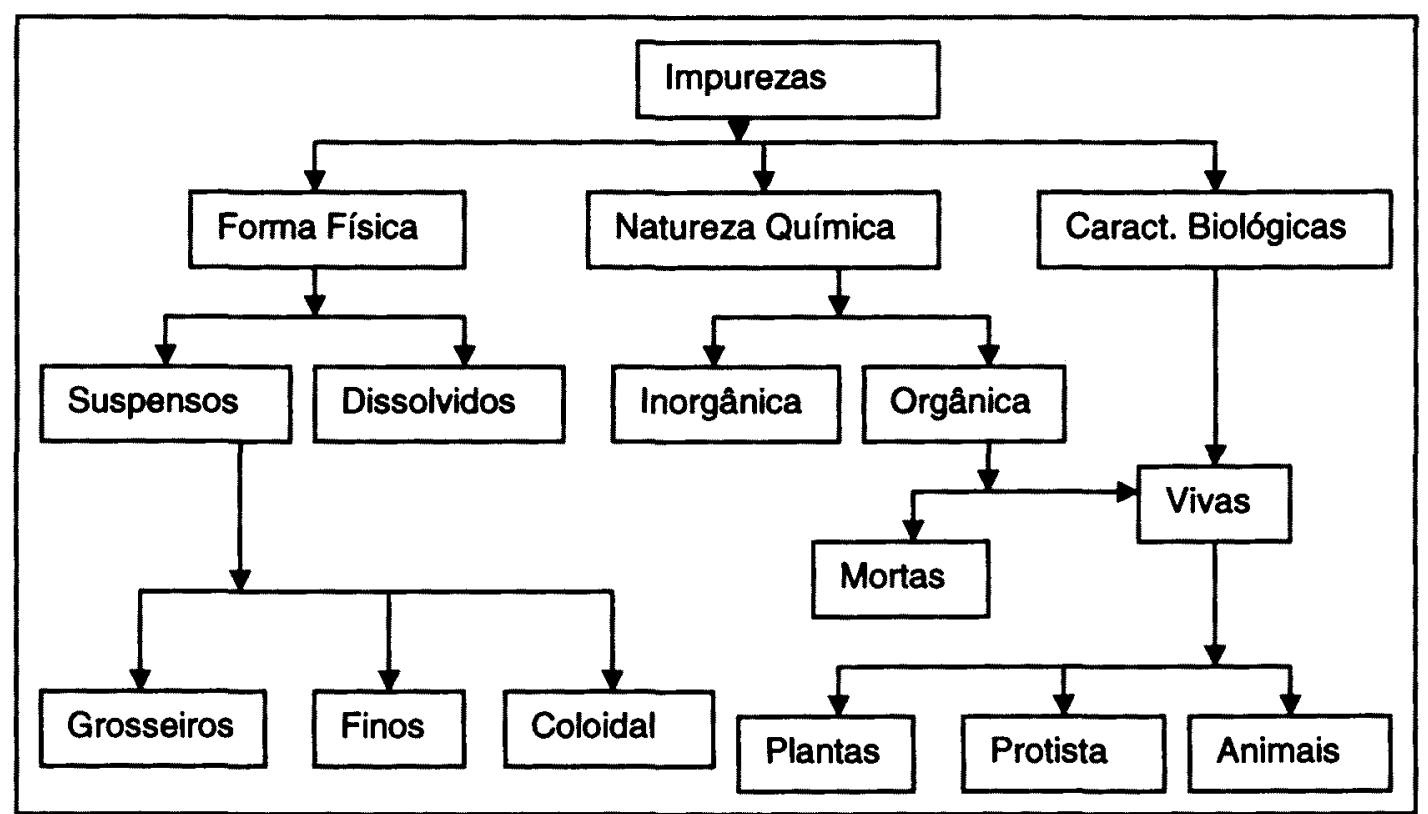

Figura 3.6 Natureza das impurezas contidas na água bruta

FONTE: BARNES et al (1981) 


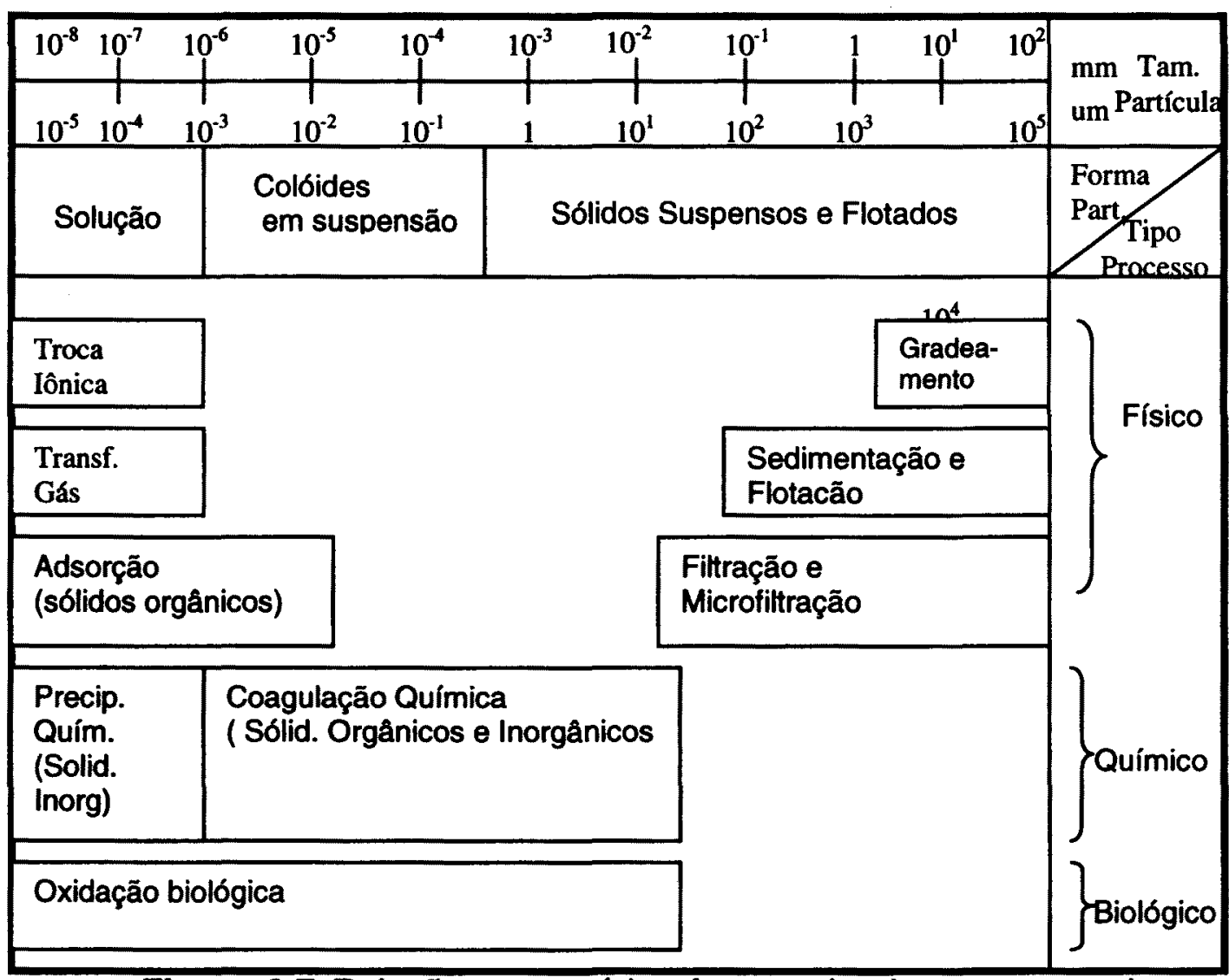

Figura 3.7 Relação entre várias formas das impurezas $\theta$ alguns processos de tratamento mais utilizados para sua remoção

FONTE: BARNES et al (1981)

Conforme FERNANDES (2002), as tecnologias de tratamento podem ser diferenciadas entre as que utilizam e não utilizam coagulação química. Entre aquelas que utilizam coagulação química podem ser citadas as de tratamento convencional completo, tratamento convencional completo de alto nível, filtração direta, filtração em linha, dupla filtração. Já o tratamento que não utiliza coagulação química é conhecido como filtração lenta que, dependendo da qualidade da água bruta, pode ou não preceder de unidades de pré-tratamento.

Di BERNARDO (1993), classifica as tecnologias de tratamento em função do uso de coagulantes ou em função da filtração lenta ou rápida. 
No tratamento de filtração lenta não há necessidade de coagulação química.

Na figura 3.8 são apresentados, segundo Di Bernardo (1993), os diversos processos utilizados no tratamento de águas brutas, comparando os tipos de filtração.

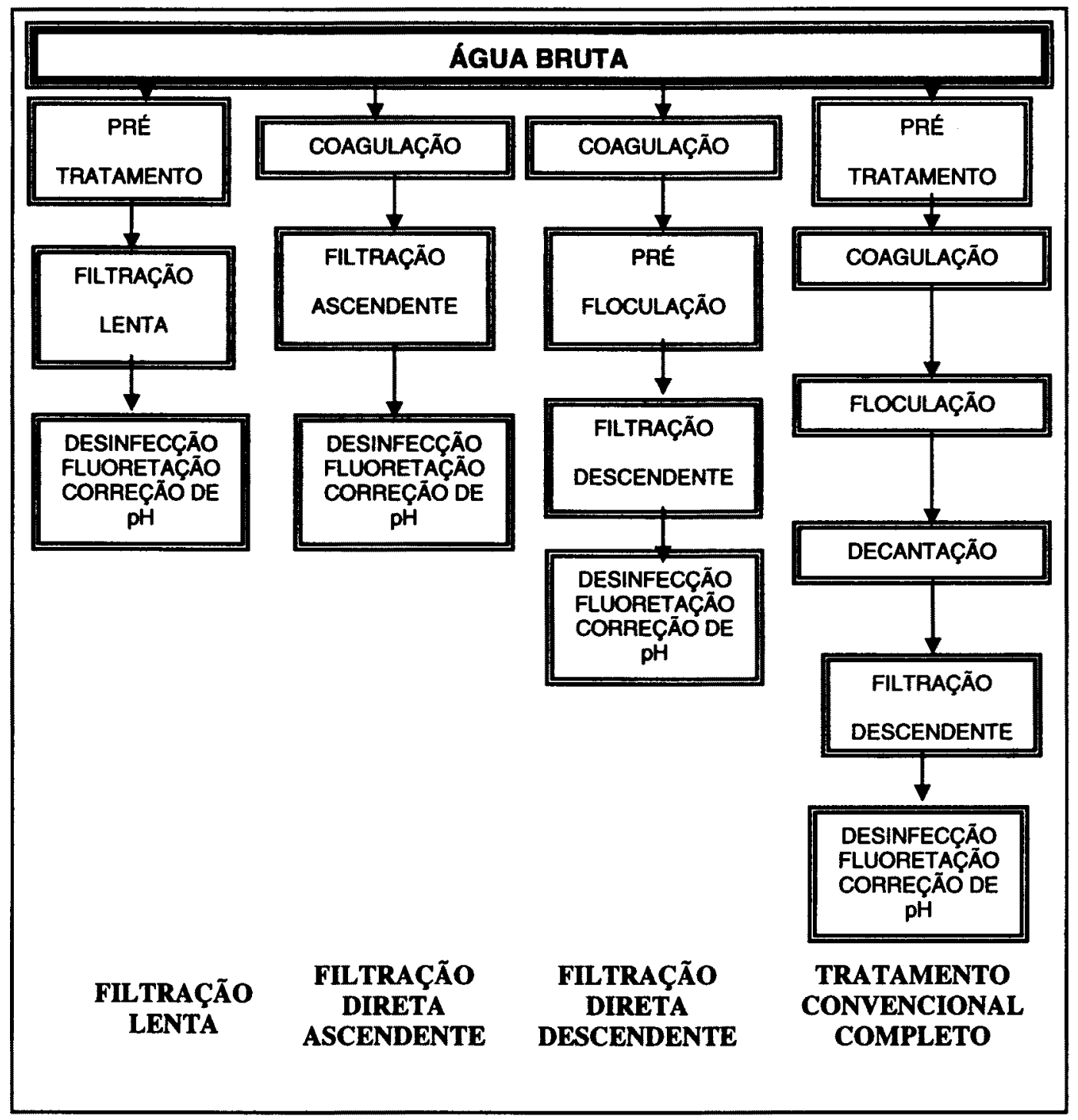

Figura 3.8 Diversos processos utilizados no tratamento de água bruta, comparando os tipos de filtração.

FONTE: Di BERNARDO (1993) 


\subsubsection{Tratamento sem coagulação química}

Em diversos países como: Colômbia, Peru, Estados Unidos e alguns países da Europa têm sido empregada em grande escala, tecnologias sem adição do processo de coagulação química. A seguir na figura 3.9 são apresentadas em forma de blocos as possiveis combinações para o tratamento de água, em função das inúmeras pesquisas experimentais realizadas nos últimos anos (Di BERNARDO 1993).

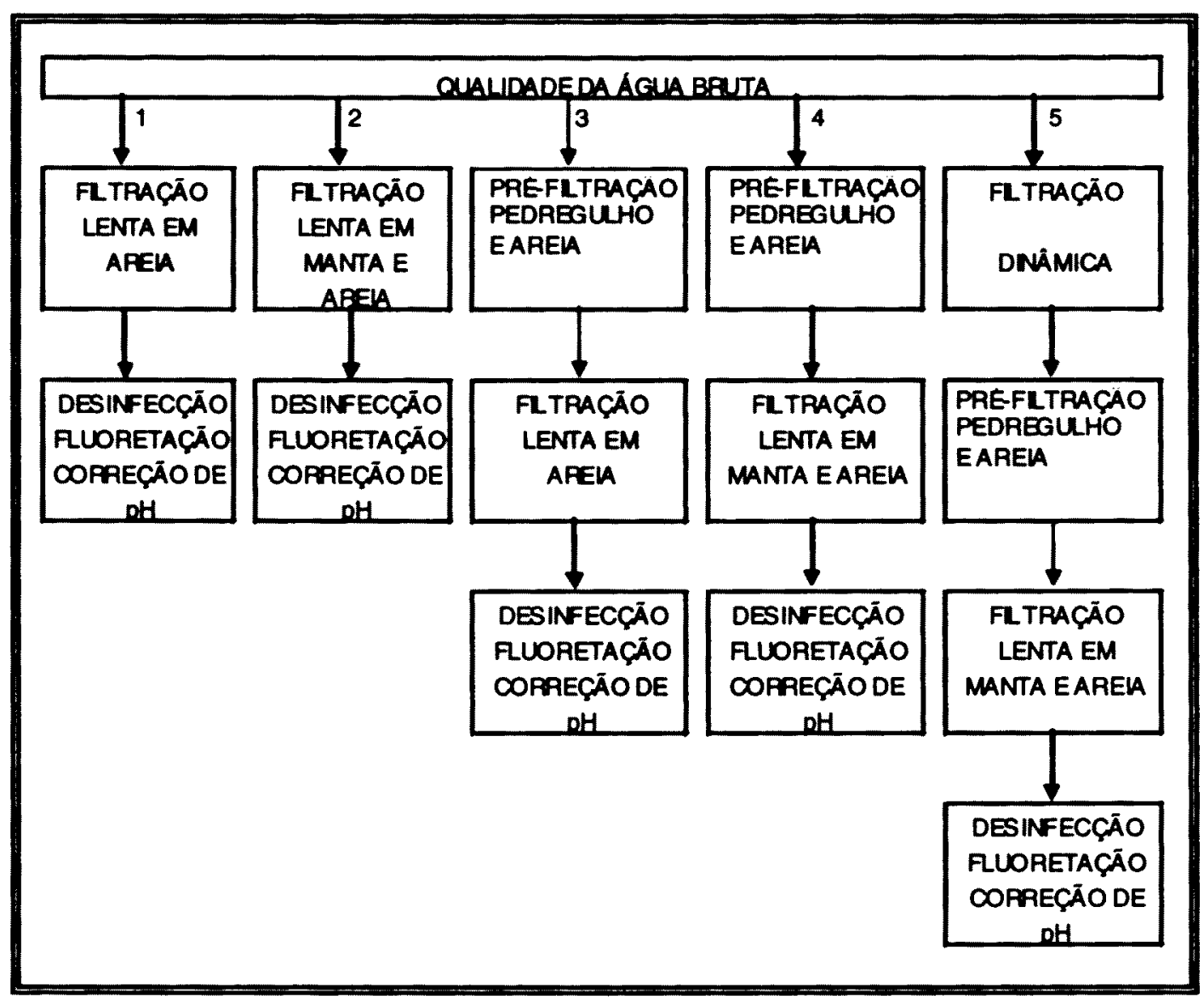

Figura 3.9 Tecnologias de Tratamento sem coagulação química.

FONTE: Di BERNARDO (1993) 
Di BERNARDO (1993), comenta que os parâmetros de qualidade da água bruta e de projetos apresentados na Tabela 3.1 poderão sofrer alterações em decorrência de novas descobertas que possam ocorrer a respeito desse tipo de tratamento assim como nos processos de filtração dinâmica e pré-filtração que estão sendo estudados em diversos centros universitários: EESC-USP - Escola de Engenharia de São Carlos Universidade de São Paulo - Brasil, ICSTM - Imperial College of Science, Tecnology and Medicine - Londres - Inglatera, IRCWD International Reference Centre for Waste Disposal - Duebendorf Suíça, Universidad Nacional de Rosario - Argentina.

KAWAMURA (2000), ressalta que esse processo apresenta vantagens e desvantagens. Por se tratar de um processo intermitente, os filtros devem ser limpos periodicamente e, para obtenção de uma água tratada com qualidade aceitável, é necessária a formação de uma camada biológica, o que ocorre geralmente em um período superior a uma semana, após a limpeza do leito de areia. As Estações que utilizam o tratamento de filtro lento $\theta$, sazonalmente captam águas brutas com faixas altas de turbidez e crescimento exagerado de algas, devem operar - sistema utilizando pré-tratamento com floculação seguida de sedimentação, em conjunto com pré-cloração.

Vantagens do processo de filtração lenta:

$>$ simples construção, custos baixos de manutenção e operação;

$>\quad$ o sistema de filtração é seguro e produz água potável de boa qualidade;

$>\quad$ processo não exige operadores altamente treinados

$>\quad$ filtros, desde que não em excesso, admitem choques de carga hidráulica e de sólidos.

Desvantagens do processo de filtração lenta:

$>\quad$ são necessárias grandes quantidades de areias; 
$>$ os filtros são facilmente comatados, devido a grande quantidade de algas;

a operação intermitente dos filtros prejudica a qualidade do efluente filtrado devido a promoção das condições anaeróbias no interior do leito.

Tabela 3.1 Parâmetros de qualidade de água bruta e de projetos (máximos), sugeridos para tecnologias sem coagulação química.

\begin{tabular}{|c|c|c|c|c|c|}
\hline \multirow[t]{2}{*}{ DISCRIMMNAÇÃo } & \multicolumn{3}{|c|}{ TECNOLOGIA } & \multicolumn{2}{|l|}{ TRATAMENTO } \\
\hline & 1 & & 3 & & 5 \\
\hline \multicolumn{6}{|l|}{ Caracteriaticas da Água Bruta } \\
\hline - Turbidez (UT) & 10 & 10 & 25 & 50 & 100 \\
\hline - Cor Verdadeira (UH) & 5 & 5 & 5 & 5 & 10 \\
\hline - Ferro total (mg Fe/L) & 1 & 1 & 3 & 3 & 3 \\
\hline - Manganés (mg Mn/L) & 0,2 & 0,2 & 0,3 & 0,3 & 0,5 \\
\hline $\begin{array}{l}-\mathrm{pH} \\
-\mathrm{DBO}_{5}(\mathrm{mg} / \mathrm{L})\end{array}$ & $\begin{array}{c}6-9 \\
5,0\end{array}$ & $\begin{array}{c}6-9 \\
5,0\end{array}$ & $\begin{array}{l}6-9 \\
10,0\end{array}$ & $\begin{array}{l}6-9 \\
10,0\end{array}$ & $\begin{array}{l}6 \cdot 9 \\
10,0\end{array}$ \\
\hline.$O D(m g / L)$ & $\geq 5,0$ & $\geq 5,0$ & $\geq 4,0$ & $\geq 4,0$ & $\geq 4,0$ \\
\hline - NMP colif. totais $/ 100 \mathrm{~mL}$ & 1000 & 2000 & 5000 & 10000 & 20000 \\
\hline - NMP colif. fecais/100mL & 500 & 500 & 1000 & 3000 & 5000 \\
\hline - Densidade algal (UPA/mL) & 250 & 250 & 1000 & 1000 & 2000 \\
\hline $\begin{array}{l}\text { - Substâncias potencialmente } \\
\text { prejudiciais à saúde pública }\end{array}$ & \multicolumn{5}{|c|}{$\begin{array}{l}\text { mesmos valores exigidos para a Água de Classe } 2 \\
\text { estipulados pela Resoluçáo CONAMA número 20/1986 }\end{array}$} \\
\hline \multicolumn{6}{|c|}{ Parâmetros de Projeto e Operaçāo } \\
\hline - Taxa no Filt. Dinâmico (m/d) & "--" & "--." & "---" & "-.." & 18 \\
\hline - Taxa Pre-filtro (m/d) & "-.." & "-.." & 36 & 24 & 18 \\
\hline - Taxa Filtro Lento (m/d) & 4 & 6 & 4 & 6 & 6 \\
\hline
\end{tabular}

FONTE: Di BERNARDO (1993)

\subsubsection{Tratamento com coagulação química}

Os processos de tratamento que utilizam coagulação têm como objetivo principal, por meio de adição de coagulantes, desestabilizar as partículas coloidais e os sólidos em suspensão, otimizando a agregação 
das partículas de menores dimensões para posterior remoção por sedimentação e/ou filtração.

A operação de sistemas com coagulação química exige mão de obra qualificada, pois tanto a coagulação quanto a floculação, constituem as partes mais delicadas do tratamento, exigindo testes em laboratório e qualquer falha nessa etapa do processo acarreta em grandes prejuizos na qualidade e custo da água tratada (POVINELLI 1987).

\subsection{Filtração direta}

Dentre as tecnologias empregadas para tratamento da água bruta, a filtração direta é a que apresenta menor custo de implantação e operação, pois as etapas de decantação (ou flotação) e, em alguns casos floculação, são excluídas do processo. A água quimicamente coagulada então é encaminhada diretamente para os filtros rápidos, com utilização de menores quantidades de coagulantes, possibilitando assim considerável redução do volume de lodo produzido. (Di BERNARDO 2003).

Contudo, AZEVEDO NETTO (1987) considera que para o bom funcionamento do processo, a água bruta não pode apresentar valores elevados de turbidez e/ou cor, pois o curto período de detenção da água na ETA, dificulta ao operador decidir quais medidas corretivas devem ser empregadas quando ocorrer variações bruscas na qualidade da água.

No Seminário realizado na Califómia (EUA) em 1976, a AWWA apresentou as seguintes indicações sobre a qualidade da água bruta a ser tratada pelo processo de filtração direta:

$>$ cor e turbidez com valores relativamente baixos, podendo ser removidas com pequenas quantidades de coagulantes, reduzindo geração de lodo;

NMP (número mais provável) de coliformes inferior a 90 por $100 \mathrm{ml}$; 
$>$ ausência de quantidades significativas de diatomáceas e de fibras de papel

Além disso, é de extrema importância a realização de ensaios de coagulação em laboratórios para verificar o efeito dos reagentes $\theta$ as dosagens necessárias que não podem ser elevadas (AZEVEDO NETTO 1986).

O processo de filtração consiste em remover da água bruta as partículas suspensas, coloidais e microorganismos através de um meio poroso sob duas formas: com ação de profundidade $\theta$ de ação superficial. Os mecanismos responsáveis pela filtração com ação de profundidade são complexos e, dependem: das características físicas $\theta$ químicas das partículas da água, do meio filtrante, da taxa de filtração e do método de operação dos filtros, resultado de uma ação de três mecanismos: transporte, aderência e desprendimento. Em contrapartida na filtração com ação superficial, a retenção do material é significativa apenas no topo do meio filtrante (Di BERNARDO 2004).

HELLER e LIBÂNIO (1996), classificam os filtros utilizados em função da velocidade de filtração, taxa de filtração, sentido de fluxo, o meio filtrante e origem da carga do leito, como mostra o quadro 3.8 .

Na NB-592 (ABNT 1989), são descritas as características básicas dos materiais que devem compor o filtro (quadro 3.9) $\Theta$, caso não possam ser efetuados ensaios em filtros piloto, a Norma estabelece em relação às taxas de filtração osseguintes valores:

$>$ FILTROS LENTOS: menor que $6 \mathrm{~m}^{3} / \mathrm{m}^{2}$.dia

$>$ FILTROS RÁPIDOS:

filtro de camada simples : $180 \mathrm{~m}^{3} / \mathrm{m}^{2}$.dia

$>$ filtro de camada dupla: $360 \mathrm{~m}^{3} / \mathrm{m}^{2}$.dia

$>$ filtro de fluxo ascendente: $120 \mathrm{~m}^{3} / \mathrm{m}^{2}$.dia 
Quadro 3.8 Classificação dos filtros segundo da velocidade de filtração, taxa de filtração, sentido de fluxo, o meio filtrante e origem da carga do leito

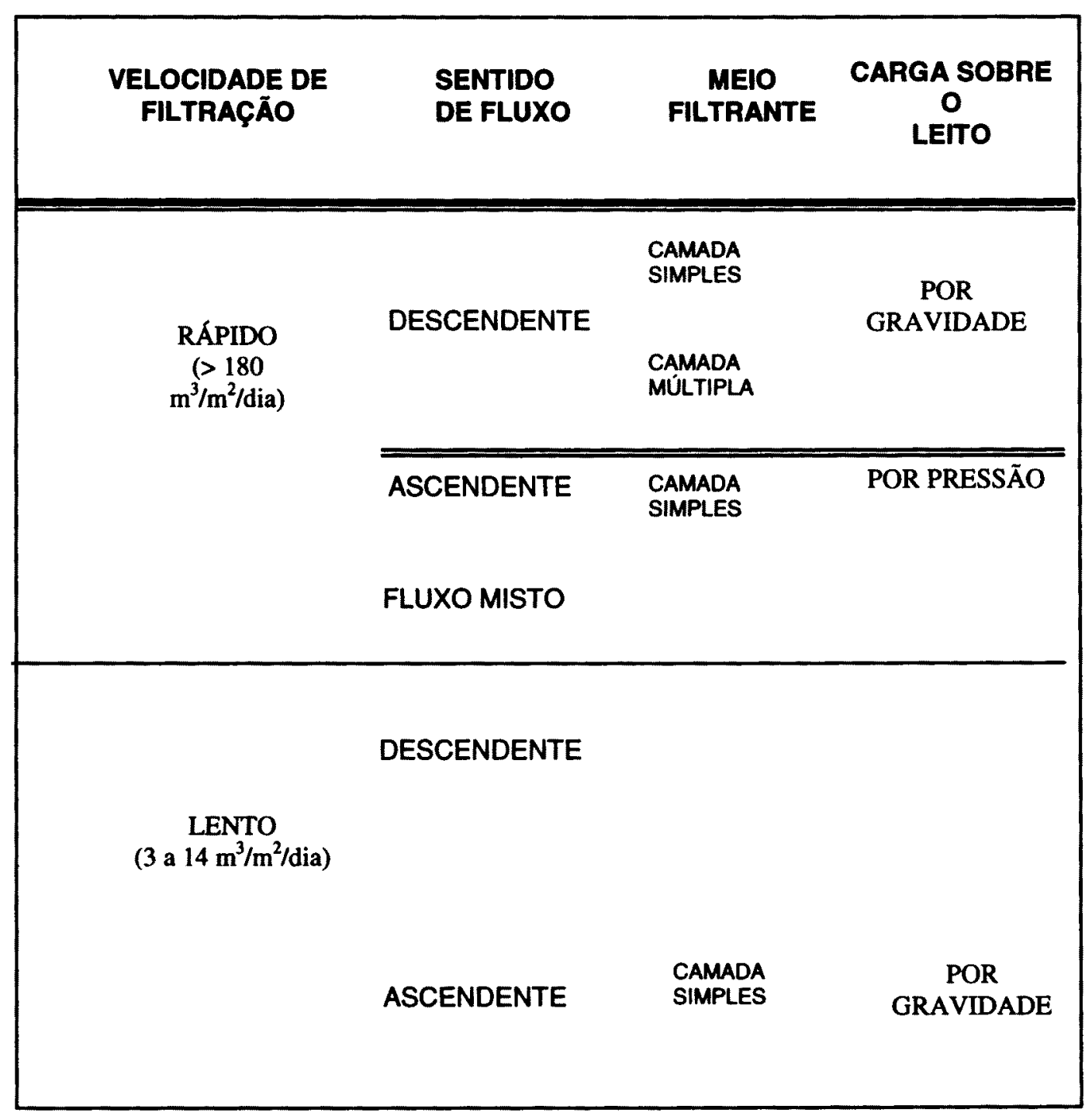

FONTE: HELLER @ LIBÂNIO (1996).

De acordo com RICHTER e NETTO (1991), o número de filtros depende da capacidade de tratamento da ETA e das taxas de filtração, sendo previstas em uma primeira fase pelo menos três filtros que geralmente não excedem $170 \mathrm{~m}^{2}$ de área 
Quadro 3.9 Características básicas dos materiais que devem compor os filtros, segundo NB-52.

\begin{tabular}{|c|c|c|c|}
\hline Tipo de Filtro & $\begin{array}{c}\text { Tamanho } \\
\text { Efetivo }\end{array}$ & $\begin{array}{c}\text { Coeficiente } \\
\text { de } \\
\text { Uniformidade }\end{array}$ & $\begin{array}{c}\text { Espessura } \\
\text { mínima }\end{array}$ \\
\hline Areia para filtros lentos & 0,25 a 0,35 & Menor que 3 & 0,90 \\
\hline $\begin{array}{c}\text { Areia para filtros } \\
\text { rápidos de fluxo } \\
\text { descendentes de } \\
\text { camada simples }\end{array}$ & 0,45 a 0,55 & 1,4 a 1,6 & 0,45 \\
\hline $\begin{array}{c}\text { Areia para filtros } \\
\text { rápidos de fluxo } \\
\text { ascendentes }\end{array}$ & 0,7 a 0,8 & $\begin{array}{c}\text { Inferior ou } \\
\text { igual a 2 }\end{array}$ & 2,0 \\
\hline $\begin{array}{c}\text { Areia para filtros } \\
\text { rápidos de fluxo } \\
\text { descendentes de } \\
\text { camada dupla }\end{array}$ & 0,40 a 0,45 & 1,4 a 1,6 & 0,25 \\
\hline $\begin{array}{c}\text { Antracito para filtros } \\
\text { de fluxo descendente, } \\
\text { de camada dupla. }\end{array}$ & 0,80 a 1,0 & $\begin{array}{l}\text { Inferior ou } \\
\text { igual a } 1,4\end{array}$ & 0,45 \\
\hline
\end{tabular}

FONTE: VIANNA (1992) apud MACEDO (2004) 
$\mathrm{Na}$ figura 3.10 são apresentadas três configurações básicas distintas como a filtração direta pode ser empregada para o tratamento de água.

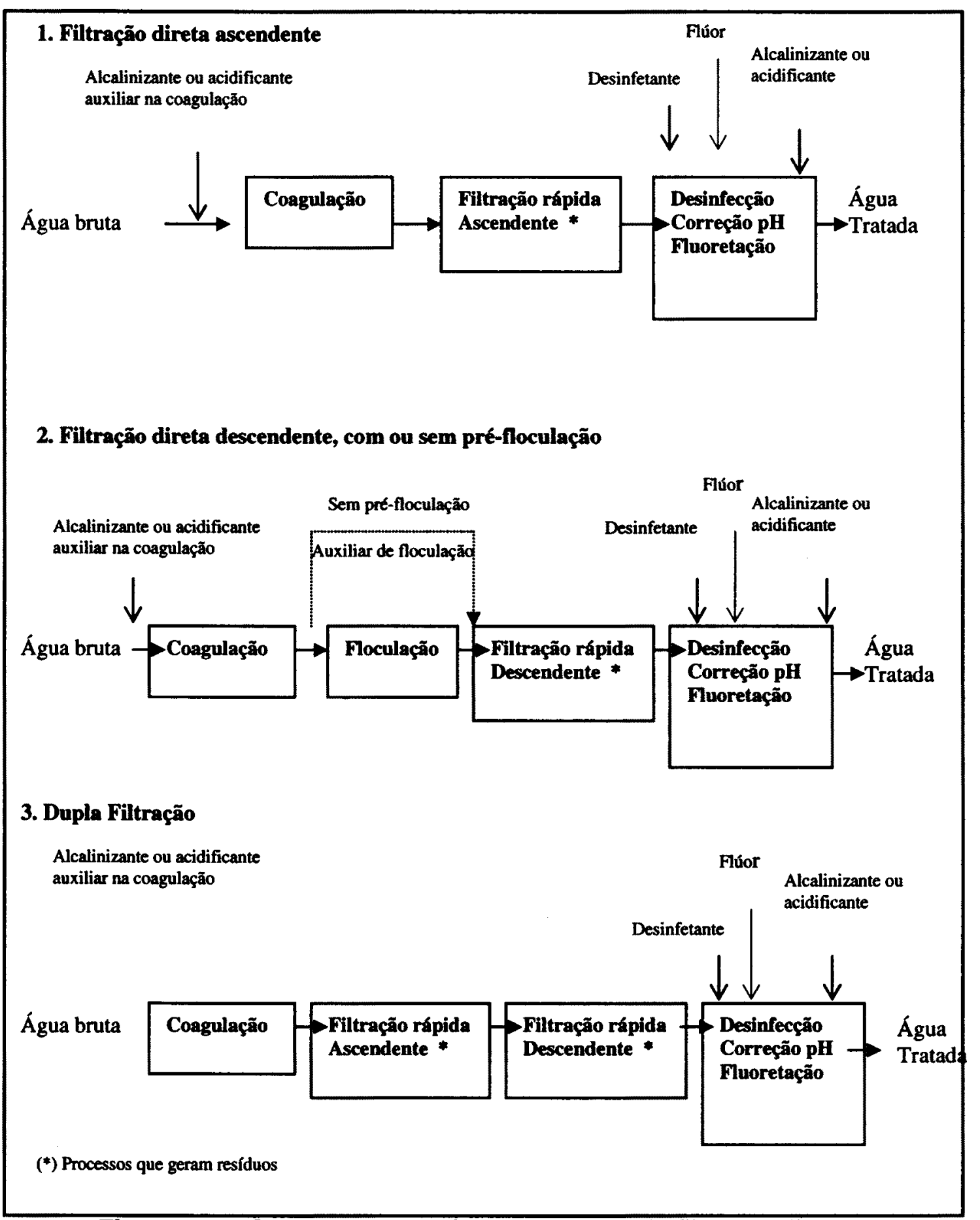

Figura 3.10 Configurações básicas distintas de filtração direta.

FONTE: Di BERNARDO (2003)

Segundo Di BERNARDO (2004), algumas variações podem ser implementadas para as configurações citadas acima: 
$>$ Filtração direta ascendente (FDA):

$>$ com camada filtrante constituída de areia e pedregulho;

$>$ com descargas de fundo intermediárias (DFI) e introdução de águas na interface (|A|);

$>$ operação com taxa constante e lavagem com água;

\section{Filtração direta descendente (FDD):}

$>$ com camada filtrante única, constituída de areia praticamente uniforme:

- operação com taxa constante e lavagens com água + auxiliar;

- operação com taxa declinante e lavagens com água + auxiliar;

$>$ com camada filtrante única, constituída exclusivamente de antracito:

- operação com taxa constante e lavagens com água + auxiliar;

- operação com taxa declinante e lavagens com água + auxiliar;

$>$ com camada filtrante dupla, de antracito e areia:

- operação com taxa constante e lavagens com água + auxiliar;

- operação com taxa declinante e lavagens com água + auxiliar;

\section{Dupla Filtração (DF)}

$>$ com filtros ascendentes de areia grossa(FAAG) e descendentes em areia (FD):

- FAAG com DFI e IAI, operados com taxa constante;

- FD com taxa constante e lavagem com água; 
- FD com taxa constante e lavagem com água + auxiliar;

- FD com taxa declinante e lavagem com água;

- FD com taxa declinante e lavagem com água + auxiliar;

$>$ com filtros ascendentes em pedregulho (FAP) e descendentes em areia (FD):

- FAP com DFI, operados com taxa constante;

- FD com taxa constante e lavagem com água;

- FD com taxa constante e lavagem com água + auxiliar;

- FD com taxa declinante e lavagem com água;

- FD com taxa declinante e lavagem com água + auxiliar,

$>$ com filtros ascendentes em pedregulho (FAP) $\theta$ descendentes em antracito e areia (FD):

- FAP com DFI, operados com taxa constante;

- FD com taxa constante e lavagem com água;

- FD com taxa constante e lavagem com água + auxiliar;

- FD com taxa declinante e lavagem com água;

- FD com taxa declinante e lavagem com água + auxiliar;

Conforme AZEVEDO NETTO (1987), são apresentadas a seguir as vantagens e desvantagens da filtração direta.

\section{Vantagens da filtração direta:}

$>$ estações mais compactas;

$>$ custo de construção 15 a $35 \%$ menor que o custo das estações convencionais; 
$>$ menores despesas com reagentes;

$>$ menor geração de lodo.

\section{Desvantagens da filtração direta:}

$>\quad$ aplicabilidade limitada $\theta$ dependente das características da água bruta;

$>\quad$ são exigidos operadores mais hábeis e operação mais cuidadosa, em função das variações da qualidade da água;

$>\quad$ lavagem mais freqüente dos filtros e conseqüentemente maior gasto com água;

$>\quad$ menor flexibilidade do processo.

\subsection{Filtração direta ascendente}

Foi atribuído ao médico italiano Porzio, em meados de 1865, a primeira menção ao uso de filtro de fluxo ascendente para o tratamento de água. Por volta de 1827 na cidade de Greenock, Escócia, foi instalada a primeira unidade de filtração direta que funcionava com fluxos ascendente e descendente, porém nos Estados Unidos, no município de Richmond, em razão do elevado grau de turbidez da água bruta, o uso dessa tecnologia não foi bem-sucedida.

A partir da metade do século XX na Europa, mais precisamente na União Soviética e na Holanda, a filtração direta ascendente passou a ser muito utilizada, surgindo, no primeiro país, o filtro $\operatorname{AKX} \theta$, no segundo, o filtro Immedium, resultado das inovações propostas para essa tecnologia. A partir de 1953, em cidades como Moscou, Leningrado, Cheliabinsk, Gorki, Kiev, Rostov, entre outras, foram construídas as ETA's com filtração ascendente, que os soviéticos denominaram "clarificação de contato".

No Brasil, a primeira experiência com filtro de fluxo ascendente foi realizada na cidade de Colatina, ES, pelo engenheiro Bemardo Grinplasht, no ano de 1971, entretanto, em função da alta turbidez da 
água bruta no filtro eram utilizadas água coagulada ou decantada. Depois de visitar a União Soviética, o Professor Azevedo Netto publicou em 1974, capítulo específico sobre a filtração ascendente, citando as principais recomendações referentes ao projeto dos clarificadores de contato, designando-os de "filtros russos" (Di BERNARDO 2004).

A tabela 3.2 apresenta os principais parâmetros de qualidade da água bruta $\Theta$ de projetos (máximos) sugeridos para filtração direta ascendente (Di BERNARDO, 1993)

Tabela 3.2 Principais parâmetros de qualidade da água bruta e de projetos.

\begin{tabular}{|c|c|c|c|c|}
\hline \multirow[t]{2}{*}{ DiscRim IN AC } & \multicolumn{4}{|c|}{ TECNOLOGIA DETRATAMENTO } \\
\hline & 1 & 2 & 3 & 4 \\
\hline \multicolumn{5}{|l|}{ Caracteristicas da $\boldsymbol{A g u}_{\mathrm{a}}$ Bruta } \\
\hline - Turbidez (UT) & 20 & 20 & 100 & 200 \\
\hline - Cor Verdadeira (UH) & 20 & 20 & 100 & 150 \\
\hline - Ferro total (mg $\mathrm{Fe} / \mathrm{L}$ ) & 2,5 & 2.5 & 15 & 15 \\
\hline - Manganos (mg Mn/L) & 0,2 & 0,2 & 1,5 & 2,5 \\
\hline $\begin{array}{l}-\mathrm{pH} \\
-\mathrm{DBO},(\mathrm{mg} / \mathrm{L})\end{array}$ & $\begin{array}{c}5-9 \\
5,0\end{array}$ & $\begin{array}{c}5-9 \\
5,0\end{array}$ & $\begin{array}{c}5-9 \\
5,0\end{array}$ & $\begin{array}{l}5-9 \\
10,0\end{array}$ \\
\hline - NMP colif. totais $/ 100 \mathrm{~mL}$ & 2500 & 2500 & 5000 & 20000 \\
\hline - NMP colit. fecais/100m L & 500 & 500 & 1000 & 5000 \\
\hline - Carbono organ. total (m g/L) & 2,0 & 2,0 & 3,0 & 5,0 \\
\hline - Densidade algal (UPA/m L) & 500 & 500 & 2500 & 5000 \\
\hline $\begin{array}{l}\text { Substancias potencialmente } \\
\text { prejudiciais a saúde pública }\end{array}$ & \multicolumn{4}{|c|}{$\begin{array}{l}\text { mesm os valores exigidos para a Agua de Classe } 2 \\
\text { estipulados pela Resoluça CONAMA número } 20 / 1986\end{array}$} \\
\hline \multicolumn{5}{|c|}{ Parimetros de Projeto o Operagio } \\
\hline - Taxa de tilt. ascend. (m/d) & $200(*)$ & 240 & 240 & 300 \\
\hline - Taxa de tilt. descend. (m/d) & "..." & "..." & "..." & 400 \\
\hline - Descargas de fundo intermed. & $(*)$ & $(*)$ & $(* * *)$ & $(* * *)$ \\
\hline - Mecanismo de coagulaqăo & adsorgăo. & neutralizaçăo de & cargas & \\
\hline
\end{tabular}

(") a taxa média de filtraçăo lim itada a $200 \mathrm{~m} / \mathrm{d} \theta$, a maxima, a $300 \mathrm{~m} / d$;

(*") deve ser reallzada uma, pelo menos, antes da lavagem do filtro; sea operaça for qualificada, pode-se executar ate quatro descargas de fundo em cada filtro, se houver entrada de água na intertace pedregulho-areia;

("**) o numero de descargas intermediarias durante a carreira de filtraça, no filtro de escoamento ascendente, dependerá da qualidade da água bruta, recomendando-se, no $\mathrm{m}$ inimo, 4 descargas por dia em cada filtro;

(1) filtração ascendente com taxa declinante

(2) filtração com taxa constante

(3) filtração com taxa constante $\theta$ descargas de fundo intermediárias

(4) filtração ascendente com taxa constante e descarga de fundo seguido de filtração descendente com taxa constante ou declinante

FONTE: Di BERNARDO (1993) 


\subsection{Filtração direta descendente}

No início da década de setenta, os pesquisadores e projetistas se preocuparam em dar atenção especial ao processo de filtração direta descendente. Em cidades próximas a grandes lagos nos Estados Unidos e Canadá, sistemas de grande e médio porte já estavam em funcionamento operando com vazões de 18 a $27 \mathrm{~m}^{3} / \mathrm{s}$.

A filtração direta descendente, segundo Di BERNARDO (2004), é definida como uma tecnologia que prescinde da sedimentação ou flotação e pode ser realizada de duas maneiras:

$>\quad$ Filtração direta descendente sem pré-floculação: mistura rápida e encaminhamento da água coagulada diretamente ao filtro;

$>\quad$ Filtração direta descendente com pré-floculação: composto por unidades de mistura rápida, floculação e filtros.

Ao se comparar à filtração direta descendente com o método convencional, podem ser destacadas algumas vantagens como: redução no custo da construção ( $30 \%$ a $50 \%$ menor); redução de custos de operação, manutenção, menor consumo de coagulantes e energia elétrica, conseqüentemente, menor geração de lodo. Em contrapartida, alguns cuidados devem ser levados em consideração: necessidade de controle mais rigoroso da dosagem de produtos químicos quando não se tem pré-floculação, dificuldades no tratamento de águas com altos valores de turbidez e cor verdadeira, tempo de detenção curto para oxidação de matérias orgânicas, ação rápida na alteração da dosagem de coagulantes durante a mudança da qualidade da água em função do tempo de detenção bastante curto.

Na Tabela 3.3 são apresentados os principais parâmetros de qualidade e de projetos sugeridos, que em função da qualidade da água a ser captada poderão variar consideravelmente. 
Tabela 3.3 Principais parâmetros de qualidade e de projetos sugeridos.

\begin{tabular}{|c|c|c|c|}
\hline DISCFIMANAÇÃO & $\begin{array}{c}\text { TECNOLOGIA } \\
1\end{array}$ & DE & TRATAMENTO \\
\hline
\end{tabular}

\section{Caracteristicas da Água Bruta}

- Turbidez (UT)

- Cor Verdadeira (uH)

$-\mathrm{pH}$

- $\mathrm{DBO}_{5}$ (mgl)

- NMP colif. totais $/ 100 \mathrm{~mL}$

- NMP colif. fecais/100mL

- Carbono orgån. total (mgll)

- Densidade algal (UPAmL)

- Substâncias potencialmente prejudiciais à saúde pública

$\begin{array}{cc}25 & 50 \\ 25 & 50 \\ 5-9 & 5-9 \\ 5,0 & 5,0 \\ 2500 & 5000 \\ 500 & 1000 \\ 1,0 & 2,5 \\ 500 & 1000\end{array}$

mesmos valores exigidos para a Água de Classe 2 estipulados pela Resolução CONAMA número 20/1986

\section{Parêmetros de Projeto e Operaçäo}

- Taxa de filtração (m/d)

- Pré-floculação

- gradiente de velocidade $\left(s^{-1}\right)$

- tempo de agitação (\$)

- Mecanismo de coagulação

$\begin{array}{cc}\left.600()^{*}\right) & \left.600()^{*}\right) \\ & 400 \\ ---" & 50-200\left(^{(* *}\right) \\ --" & 200-900\left(^{* * *}\right) \\ \text { utralização de cargas } & \end{array}$

adsorção - neutralização de cargas

(") dependendo da qualidade da água bruta e das características do meio filtrante; no caso da filtração com taxa declinante, a taxa minima também poderia ser limitada a $600 \mathrm{~m} / \mathrm{d}$, comumente, são utilizados valores entre 200 e $400 \mathrm{~m} / \mathrm{d}$.

("*) depende da qualidade da água bruta e uso de auxiliar de floculação

(***) depende da qualidade da água bruta, tipo de coagulante primário, uso de auxiliar de coagulação ou floculação e gradiente de velocidade.

(1) filtração com taxa constante ou declinante

(2) pré-floculação precedida de filtração com taxa constante ou declinante

FONTE: Di BERNARDO (1993) 


\subsection{Tratamento em ciclo completo}

O tratamento em ciclo completo, segundo Di BERNARDO (1993), deve ser empregado quando a qualidade da água tratada submetida aos tratamentos citados anteriormente não atender aos padrões da legislação. Neste método de tratamento são aplicados os seguintes processos unitários: coagulação, floculação, sedimentação, filtração antes do condicionamento final para posterior distribuição.

AZEVEDO NETTO (1987), ressalta a importância da disposição das diversas unidades de purificação em uma estação de tratamento, pois os resultados dependem diretamente do arranjo das partes que integram o processo. Apesar das estações serem projetadas de forma compacta, essa compacidade não deve interferir, principalmente em estações de ciclo completo na facilidade de operação.

FERNANDES (2002), comenta que a idéia de preservação dos corpos d'água implica diretamente no desempenho de uma estação de tratamento e no consumo de produtos químicos.

Em função das atividades antrópicas, através do lançamento de águas residuárias domésticas $\theta$ industriais que acarretam na degradação da qualidade das águas dos mananciais, Di BERNARDO (1993) propõe que para garantir a qualidade da água a ser distribuída é necessário que sejam aplicados outros processos, além dos citados anteriormente, como por exemplo: adsorção em canão ativado, oxidação com permanganato de potássio e pré-desinfeç̧ão com ozônio e dióxido de cloro. Na figura 3.11 é apresentado um fluxograma geral de um sistema de tratamento completo com possiveis variações 


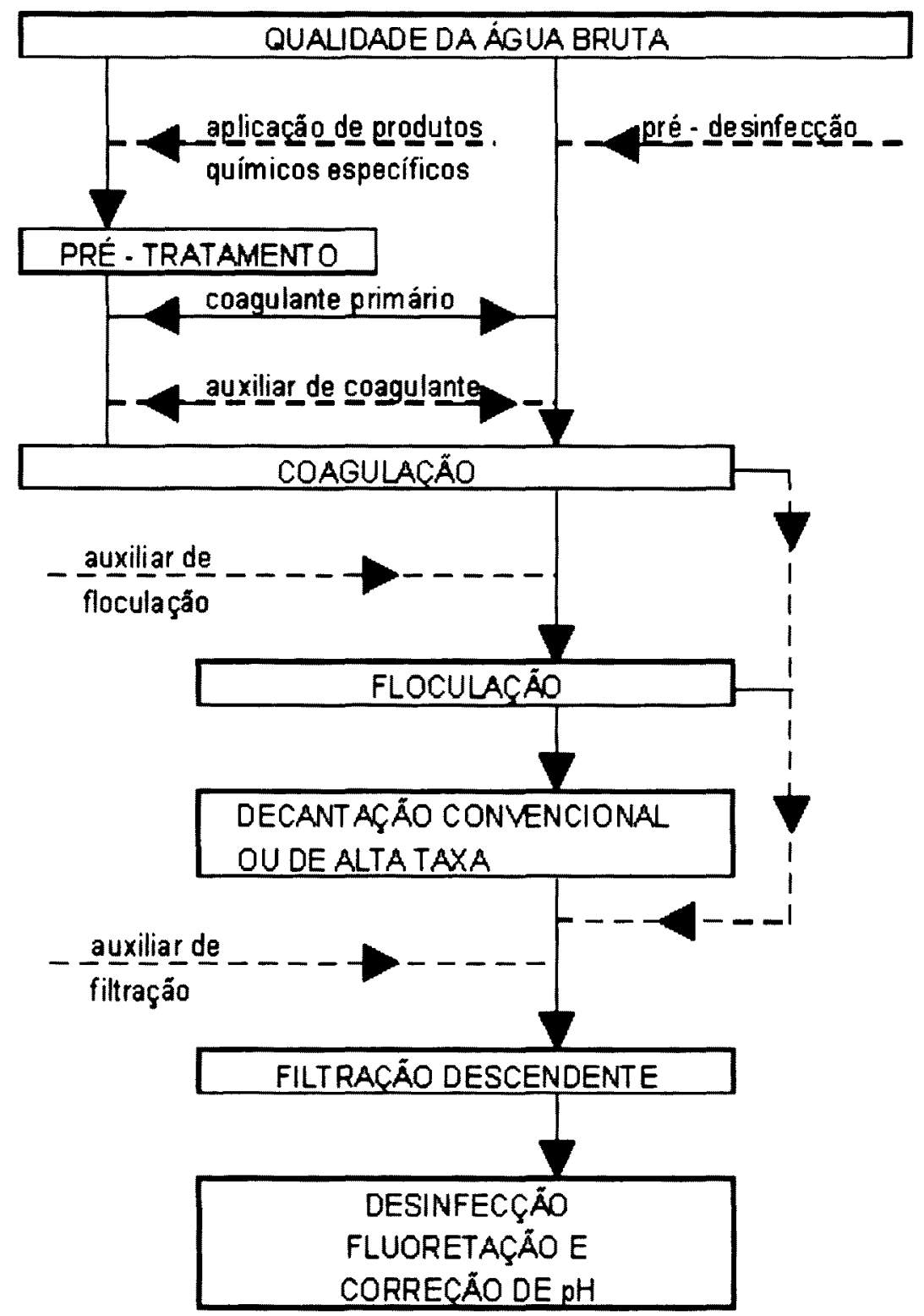

Figura 3.11 Fluxograma geral de um sistema de tratamento completo, com possiveis variações.

FONTE: Di BERNARDO (1993) 


\subsubsection{Mecanismos de coagulação}

O processo de coagulação é a primeira operação unitária no processo de tratamento convencional e seu objetivo principal é promover a desestabilização das cargas dos colóides, dos sólidos em suspensão, inclusive vírus e bactérias, por meio de adição de coagulantes (KAWAMURA 2000).

Para uma perfeita remoção das impurezas presentes na água bruta, é necessário que ocorra a alteração de suas características físicoquímicas, através da adição de produtos químicos, coagulantes, que consiste em desestabilizar as partículas coloidais, contribuindo para a formação de flocos maiores e mais densos, sendo removidos posteriormente no processo de sedimentação (STUMM et al 1968).

De um modo geral, segundo MONTGOMERY (1985) a coagulação depende fundamentalmente das características dos coagulantes, das impurezas e características das águas, conhecidas através de parâmetros como: $\mathrm{pH}$, alcalinidade, turbidez, temperatura, força iônica, sólidos totais dissolvidos e distribuição de tamanhos de partículas em estado coloidal. Os dois principais produtos inorgânicos utilizados no processo de coagulação são os sais de alumínio e ferro.

Di BERNARDO (1993), afirma que a coagulação é o resultado de dois fenômenos: o primeiro químico, quando são adicionados na água bruta sais de alumínio e ferro, ocorrendo assim reações de coagulantes com as partículas da água, contribuindo para formação de espécies hidrolisadas com carga positiva e, em seguida, o fenômeno físico, que consiste em transportar as espécies hidrolisadas, para que na unidade de mistura rápida, possam entrar em contato com as impurezas a serem removidas. Há posteriormente a necessidade de agitação lenta para que ocorram choques entre as impurezas que ao se aglomerarem formam partículas maiores denominadas flocos. 
LORENZ (1995) apud TEIXEIRA (1999), cita que o alumínio vem sendo muito utilizado como coagulante por se tratar de um sal de alta solubilidade, fácil transporte e por possuir uma faixa de $\mathrm{pH}$ próximo das águas naturais. Em contrapartida, os sais de ferro vêm ganhando uma maior atenção e espaço no mercado, por ter um custo inferior ao sulfato de alumínio, maior faixa de trabalho de $\mathrm{pH}$, características dos flocos formados, reduzido volume de lodo gerado e à melhoria nas características de desidratação do resíduo resultante.

A seguir são apresentados os tipos de coagulantes $\theta$ auxiliares de coagulação mais utilizados no tratamento de água (Quadro 3.12).

Quadro 3.12 Tipos de coagulantes e auxiliares de coagulação mais utilizados no tratamento de água.

\begin{tabular}{|c|c|}
\hline \multirow{7}{*}{ Coagulantes } & Sulfato de Alumínio $-\mathrm{Al}_{2}(\mathrm{SO} 4)_{3 .} 14 \mathrm{H}_{2} \mathrm{O}$ \\
\hline & Cloreto Férrico - $\mathrm{FeCl}_{3} .6 \mathrm{H}_{2} \mathrm{O}$ \\
\hline & Sulfato Férrico $-\mathrm{Fe}_{2}\left(\mathrm{SO}_{4}\right)_{3}$ \\
\hline & Sulfato Ferroso - $\mathrm{FeSO}_{4} .7 \mathrm{H}_{2} \mathrm{O}$ \\
\hline & Óxido de Cálcio - Cão \\
\hline & Policloreto de alumínio \\
\hline & Hidróxido de cálcio - $\mathrm{Ca}(\mathrm{OH})_{2}$ \\
\hline $\begin{array}{l}\text { Auxiliares } \\
\text { de }\end{array}$ & $\begin{array}{l}\text { Polímeros (catiônicos, aniônicos ou não } \\
\text { iônico) }\end{array}$ \\
\hline Coagulação & Aluminato de sódio $-\mathrm{Na}_{2} \mathrm{OAl}_{2} \mathrm{O}_{3}$ \\
\hline
\end{tabular}

FONTE: AWWA (1991) apud TEIXEIRA (1999)

Segundo AWWA (1991), existem quatro formas de desestabilizar as partículas coloidais: compressão da camada difusa, adsorçãoneutralização, varredura, adsorção e formação de pontes. E conforme Di BERNARDO et al (1987) apud FERREIRA FILHO (1996), os 
mecanismos de adsorção-neutralização $\Theta$ varredura são os mais importantes quando são utilizados sais de alumínio e ferro.

\subsubsection{Compressão da camada difusa}

Di BERNARDO (1993) comenta que, desde o final do século XIX era de conhecimento dos pesquisadores que, para a desestabilização de um sistema coloidal bastava adicionar íons com carga contrária à das partículas coloidais. Ao se introduzir em um sistema coloidal eletrólitos indiferentes, como por exemplo, cloreto de sódio, que não possuem características de hidrólise ou de adsorção, ao contrário dos sais de alumínio e ferro, ocorrerá um aumento da densidade de cargas na camada difusa, diminuindo a esfera de influência das partículas, ocorrendo coagulação por compressão da camada difusa.

Segundo FERNANDES (2002), a coagulação por compressão da camada difusa ocorre pela presença de grandes quantidades de eletrólitos indiferentes, provocando assim um aumento na concentração de íns positivos a negativos (forças iônicas) da camada difusa. São então atraídos para as proximidades da superfície do colóide que, para se manter eletricamente nula tem seu volume reduzido de forma que as forças resultantes (forças de Van der Waals) de atração entre as partículas sejam dominantes $\theta$, ao eliminar a estabilização eletrostática, resulte no processo de coagulação.

Conforme Di BERNARDO (1993), a estabilidade do sistema é obtida através da interação entre as forças de repulsão de origem elétrica e da força de atração de Van der Waals, cujas partículas se movimentam de forma contínua devido ao Movimento Browniano. 
$\mathrm{Na}$ figura 3.12, são apresentadas as curvas resultantes das interações entre partículas coloidais semelhantes.

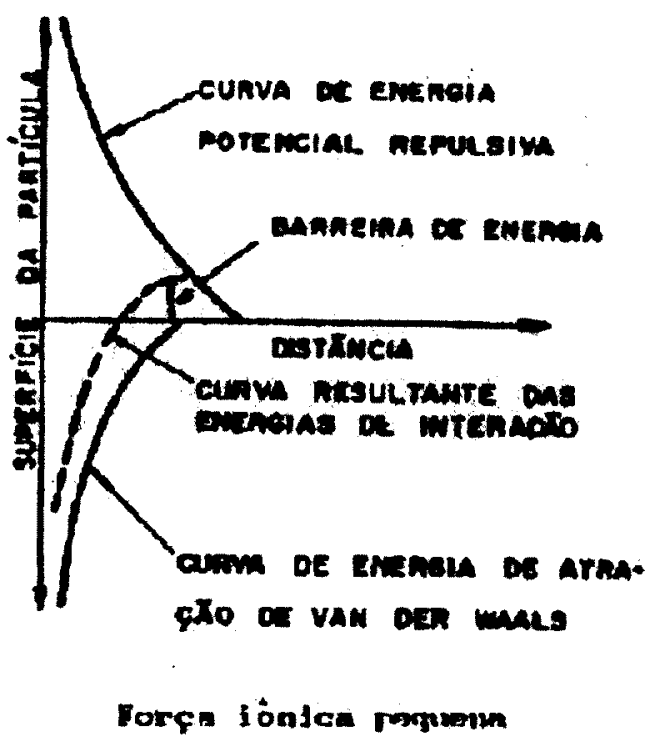

Figura 3.12 Curvas resultantes das energias variando concentração de cargas na camada difusa.

FONTE: Di BERNARDO (1993)

A configuração esquemática da dupla camada elétrica a partir de uma partícula coloidal negativa com acúmulo de íons positivos na interface sólido-líquido formando juntamente com as cargas negativas da partícula a Dupla Camada Elétrica, é apresentada na figura 3.13.

A Camada Difusa é basicamente formada pela força de atração dos íons negativos e positivos presentes na camada compacta, pela repulsão eletrostática de íons negativos e pela difusão térmica. Tal camada tem sua origem a partir da também denominada Camada de Stem, onde existe uma elevada concentração de íns positivos próximos à superfície do colóide. 


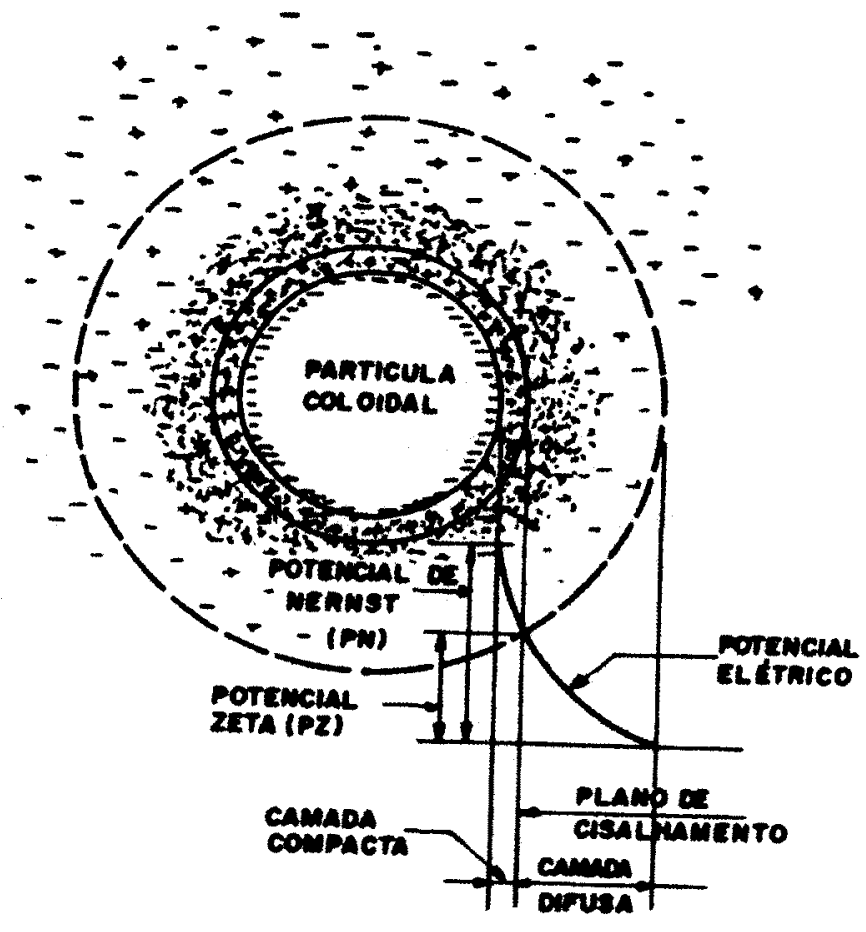

Figura 3.13 Configuração esquemática da dupla camada elétrica.

FONTE: Di BERNARDO (1993)

\subsubsection{Adsorção e neutralização de carga}

Na natureza, segundo Di BERNARDO (2002), algumas espécies por possuírem carga contrária à da superfície das partículas coloidais são capazes de serem adsorvidas pelos colóides, ocorrendo desestabilização dos mesmos. Tal atração é resultado de interações como ligação de hidrogênio, ligações covalentes e reações de troca iônica.

No processo de adsorção e neutralização de cargas, espécies poliméricas hidrolisadas são produzidas ao serem adicionados coagulantes como sais de alumínio ou ferro, resultantes das reações de compostos trivalentes com a água. Tais espécies são adsorvidas na 
superfície dos colóides neutralizando parte dos mesmos. Segundo O'MELIA et al (1967), os íons hidrolisados possuem um maior poder de adsorção e redução de cargas dos colóides quando comparados com ions metálicos não hidrolisados.

FERREIRA FILHO (1993) cita que, em intervalos de pH utilizados nos processos de coagulação de águas de abastecimento, as espécies hidrolisadas estão presente em maior concentração quando comparadas com íons metálicos não hidrolisados. Portanto, o grau de redução da carga da partícula é função da concentração de colóides e da dosagem do coagulante para um mesmo pH, contradizendo a Teoria da Dupla Camada, que afirma que a redução de carga da partícula para uma mesma dosagem de coagulante é independente da concentração de colóides.

De acordo com Di BERNARDO (1993), na coagulação de águas com turbidez relativamente elevada comparada à cor verdadeira, quando são empregados sais de ferro $(+3)$ ou alumínio predominam os mecanismos de adsorção e neutralização de cargas $\theta$ de varredura, formando assim espécies hidrolisadas, que devem encontrar partículas coloidais para se obter uma melhor eficiência no processo de coagulação.

A adsorção e neutralização de cargas é um mecanismo muito importante quando são empregados no tratamento de água de abastecimento processos de filtração direta, pois não há necessidade de formação de flocos para posterior sedimentação, mas deve ocorrer a desestabilização de partículas que serão removidas no meio filtrante (Di BERNARDO, 2002).

$\mathrm{Na}$ figura 3.14 são apresentadas as interaçōes que ocorrem na coagulação, empregando-se como coagulante o sulfato de alumínio. 


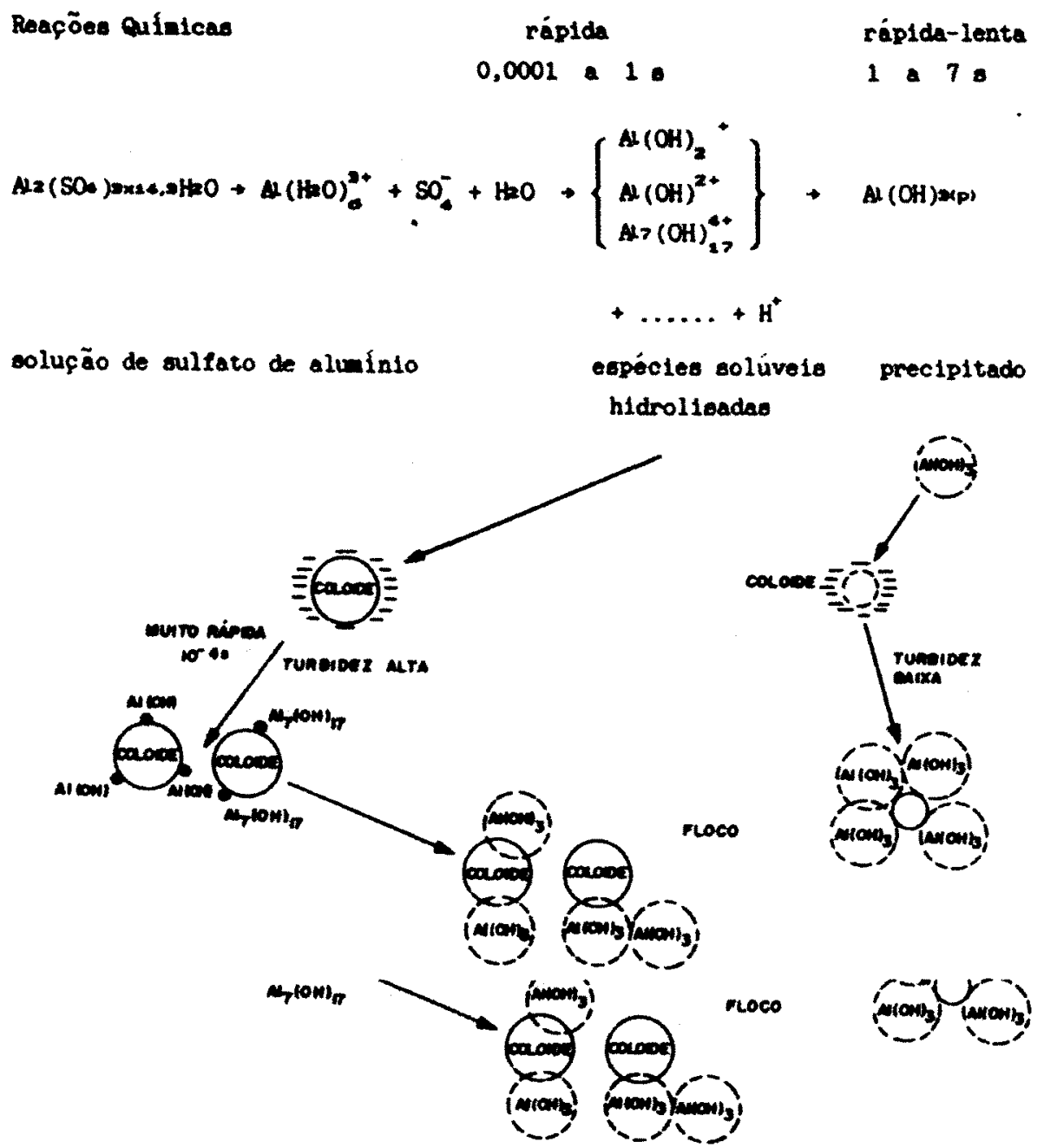

Figura 3.14 Interações que ocorrem na coagulação, empregandose como coagulante o sulfato de alumínio.

FONTE: Di BERNARDO (1993)

\subsubsection{Varredura}

No mecanismo de varredura, a desestabilização das partículas coloidais ocorre a partir da adição de coagulantes em meio aquoso, que dependendo da quantidade adicionada, do $\mathrm{pH}$ da mistura $\Theta$ da concentração de alguns ions na água, acarretará na formação de precipitados $\mathrm{Al}(\mathrm{OH})_{3}(p)$ e $\mathrm{Fe}(\mathrm{OH})_{3}(p)$ (FERREIRA FILHO 1993). 
Em função da formação de flocos de maiores dimensões e velocidades de sedimentação relativamente altas quando comparados com flocos resultantes do processo de adsorção-neutralização, o mecanismo por varredura é muito utilizado em estações de tratamento de água onde são empregados os processos de floculação e sedimentação antecedendo filtração. A figura 3.15 ilustra o mecanismo de coagulação por varredura.

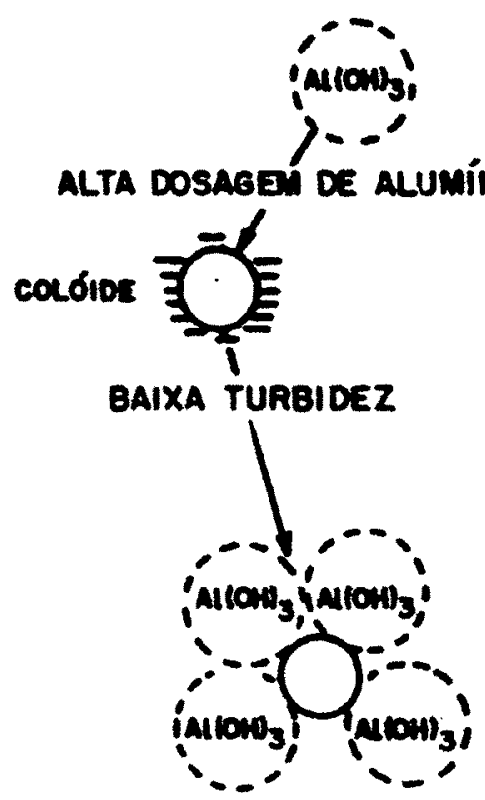

Figura 3.15 Mecanismos de coagulação por varredura.

FONTE: AMIRTHARAJAH. et al (1982) apud TEIXEIRA (1999).

Estudos realizados por Di BERNARDO (1987) utilizando água com cor verdadeira alta $(100 \mu \mathrm{H})$ em relação a turbidez $(5 \mu \mathrm{T})$ e outra com cor verdadeira baixa $(5 \mu \mathrm{H})$ com turbidez $(200 \mu \mathrm{T})$ e alcalinidade de 30 a $40 \mathrm{mg} / \mathrm{L}$ de $\mathrm{CaCO}_{3}$, coaguladas respectivamente nos mecanismos de adsorção-neutralização e varredura, demonstraram que:

a região de adsorção é caracterizada por valores baixos de $\mathrm{pH}$ e dosagens de coagulantes inferior que os da região da varredura;

a faixa de valores de dosagem de coagulantes e $\mathrm{pH}$ da mistura que produz resultados satisfatórios é bem mais estreita no 
mecanismo de adsorção-neutralização quando comparados com mecanismo de varredura;

$>\quad$ as condições de mistura rápida $e$ de floculação não são necessariamente as mesmas quando são diferentes os mecanismos de coagulação.

Segundo JAMES et al (1982) apud FERNANDES (2002), a utilização de polimeros no processo de coagulação pode levar a redução das quantidades de coagulantes empregados, com considerável redução do volume de lodo gerado que, em função da precipitação do hidróxido de alumínio ou ferro produz um resíduo bastante volumoso e gelatinoso. Neste caso o coagulante auxiliará na desestabilização das partículas e, os polímeros de alto peso molecular auxiliarão na adsorção dos flocos aumentando seu tamanho, garantindo assim boas condições de sedimentabilidade.

\subsubsection{Adsorção e formação de pontes}

No mecanismo de adsorção e formação de pontes são utilizados diversos compostos naturais e sintéticos, denominados polímeros, sendo introduzido o termo polieletrólitos por Fuoss em 1947, caracterizados por apresentar grandes estruturas moleculares com carga ao longo de sua cadeia e capazes de agir como eficiente coagulante. Podem ser classificados aniônicos (carga negativa), catiônicos (carga positiva) $\theta$ não-iônicos (carga neutra) (FERREIRA FILHO 1993).

MONTGOMERY (1985), explica que por se tratar de um mecanismo de adsorção, a dosagem ótima de polieletrólito é proporcional à concentração das partículas coloidais. Polímeros aniônicos, catiônicos e não-iônicos devem funcionar como formadores de pontes químicas, entretanto, os polímeros mais usados como coagulantes primários na desestabilização de partículas coloidais são tipicamente catiônicos e de baixo peso molecular (AWWA 1989). 
Conforme O'BRIEN @ NOVAK (1977) apud MONTGOMERY (1985), a escolha do polímero exige testes empiricos em razão da complexidade das interações que ocorrem durante o mecanismo. De um modo geral, polímeros aniônicos tem sido empregados como um eficiente auxiliar de coagulação, enquanto, os polímeros não-iônicos demonstraram ser eficiente no processo de filtração.

$\mathrm{Na}$ figura 3.16, são apresentadas as reaçōes no mecanismo de adsorção e formação de pontes, utilizando polímeros.

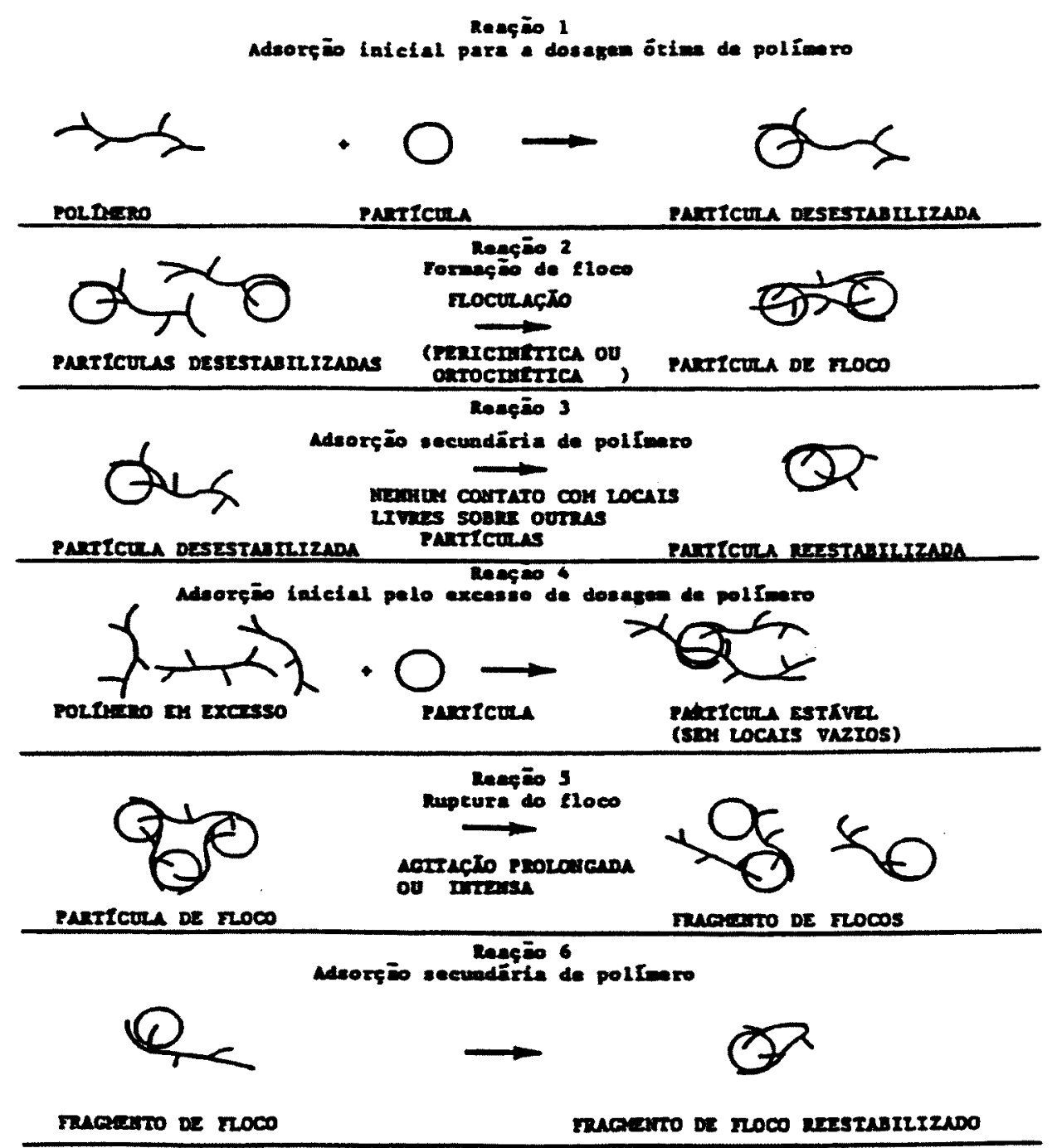

Figura 3.16 Reações no mecanismo de adsorção e formação de pontes, utilizando polímeros.

FONTE: WEBER Jr. (1972) apud YUZHU (1996). 


\section{REsíduos gerados NAS Estações DE TRATAMENTO DE ÁGUA}

\subsection{Origem dos lodos}

As ETA's que empregam o processo completo ou convencional (coagulação, floculação, decantação e filtração) no processo de potabilização da água, utilizam produtos químicos que auxiliam na formação de flocos, otimizando a sedimentabilidade das partículas resultando em resíduos denominados lodos.

Os lodos considerados sub-produtos dos processos aplicados no tratamento de água, conforme GRANDIM (1992), são gerados principalmente nos decantadores e filtros. Também são gerados resíduos sólidos nos tanques de floculação e nos tanques de preparo de soluções e suspensões de produtos químicos, adicionados nos processos de tratamento em função das lavagens periódicas dessas unidades, embora seu volume não seja significativo.

SOBRINHO (1993), cita que a quantidade e qualidade dos lodos gerados dependem fundamentalmente dos seguintes fatores: características físicas da água bruta (sólidos em suspensão, turbidez e cor), frequência de remoção de lodo dos decantadores, freqüência de lavagem dos filtros, modo de operação dos tanques de equalização existentes ou a instalar, dosagens de produtos químicos utilizados no tratamento, tipos de coagulantes e auxiliares de coagulação.

Conforme AWWA (1987) apud FERREIRA FILHO (2000), os resíduos gerados nas ETA's podem ser divididos em quatro categorias:

$>$ resíduos sólidos gerados nos decantadores (ou flotadores com ar dissolvido) e águas de lavagens de filtro, quando os processos aplicados visam remoção de cor e turbidez; 
$>$ resíduos sólidos gerados durante processo de abrandamento;

$>$ resíduos gerados quando são utilizados processos que visam redução de matéria orgânica presentes na água bruta: carvão ativado granular saturado, ar proveniente de processos de arraste de ar, etc;

$>$ resíduos líquidos gerados quando são aplicados processos de membrana (osmose reversa, ultrafiltração e nanofiltração), visando a remoção de compostos inorgânicos.

YUZHU (1996) comenta que, através de vários estudos, alguns pesquisadores chegaram a porcentagens de lodo gerados nos decantadores e lavagem dos filtros (quadro 4.1)

Quadro 4.1 Porcentagem de lodo gerados nos decantadores e lavagem dos filtros.

\begin{tabular}{|c|c|c|}
\hline Pesquisador & Decantadores & Filtros \\
\hline MONTGOMERY & 60 a $90 \%$ & 10 a $30 \%$ \\
\hline LEVESQUE & 90 a $95 \%$ & 5 a $10 \%$ \\
\hline O'CONNORS & 60 a $70 \%$ & 30 ou $40 \%$ \\
\hline
\end{tabular}

FONTE: YUZHU (1996)

A remoção desse material sólido nos decantadores pode ser feita continua ou periodicamente. Em função do volume de água tratada, a remoção pode ser manual ou mecanizada. No caso de remoção manual, a freqüência de retirada é de uma vez a cada três meses. Nas estações que utilizam remoção mecanizada, os equipamentos são projetados para operar em períodos que variam uma vez por semana ou por hora ou de forma contínua (MONTGOMERY 1985). 
Os lodos gerados na unidade de filtração são removidos durante 0 processo de lavagem dos filtros, geralmente, em intervalos de 12 a 48 horas, por 4 a 10 minutos. A turbidez da água de lavagem é da ordem de 200 UNT e, a concentração de sólidos totais varia de 0,01 a 0,1\%, com DBO5 de $10 \mathrm{mg} / \mathrm{l}$ e DQO de $100 \mathrm{mg} /$. A sedimentação dos sólidos da água de lavagem gera um lodo que ao ser adensado pode atingir concentração de sólidos de 1 a 2\% (O'CONNOR 1971).

Conforme CORNWELL (1987), estudos realizados por LAMB e BAILEY, demonstraram que lodos resultantes da coagulação utilizando sulfato de alumínio causavam efeitos nocivos aos organismos $T$. dissimilis, da familia chironomídeos. Esses organismos ocupam grande parte da camada bentônica, sendo de fundamental importância na alimentação dos peixes. A figura 4.1 apresenta a taxa de mortalidade das espécies em relação ao aumento da quantidade de alumínio presente no lodo.

Ainda segundo CORNWELL (1987), SCHOLFILD e TROJNAR, realizaram experiências com trutas variando a dosagem de sulfato de alumínio e, concluíram que na faixa de 0,2 a $0,5 \mathrm{mg} / \mathrm{L}$ já ocorria a morte dos peixes, porém não conseguiram distinguir as formas de alumínio presentes.

HALL et al (1985) apud AWWA (1987), ao promoverem estudos de monitoramento biológico, adicionando alumínio em rios com pouco volume de água, observaram alterações físicas, químicas e biológicas nesses cursos d'água, variações de estruturas, distribuição, abundância e diversidade das comunidades macrobentônicas, além da redução da tensão superficial, provocando conseqüentemente alteração na biota aquática. 

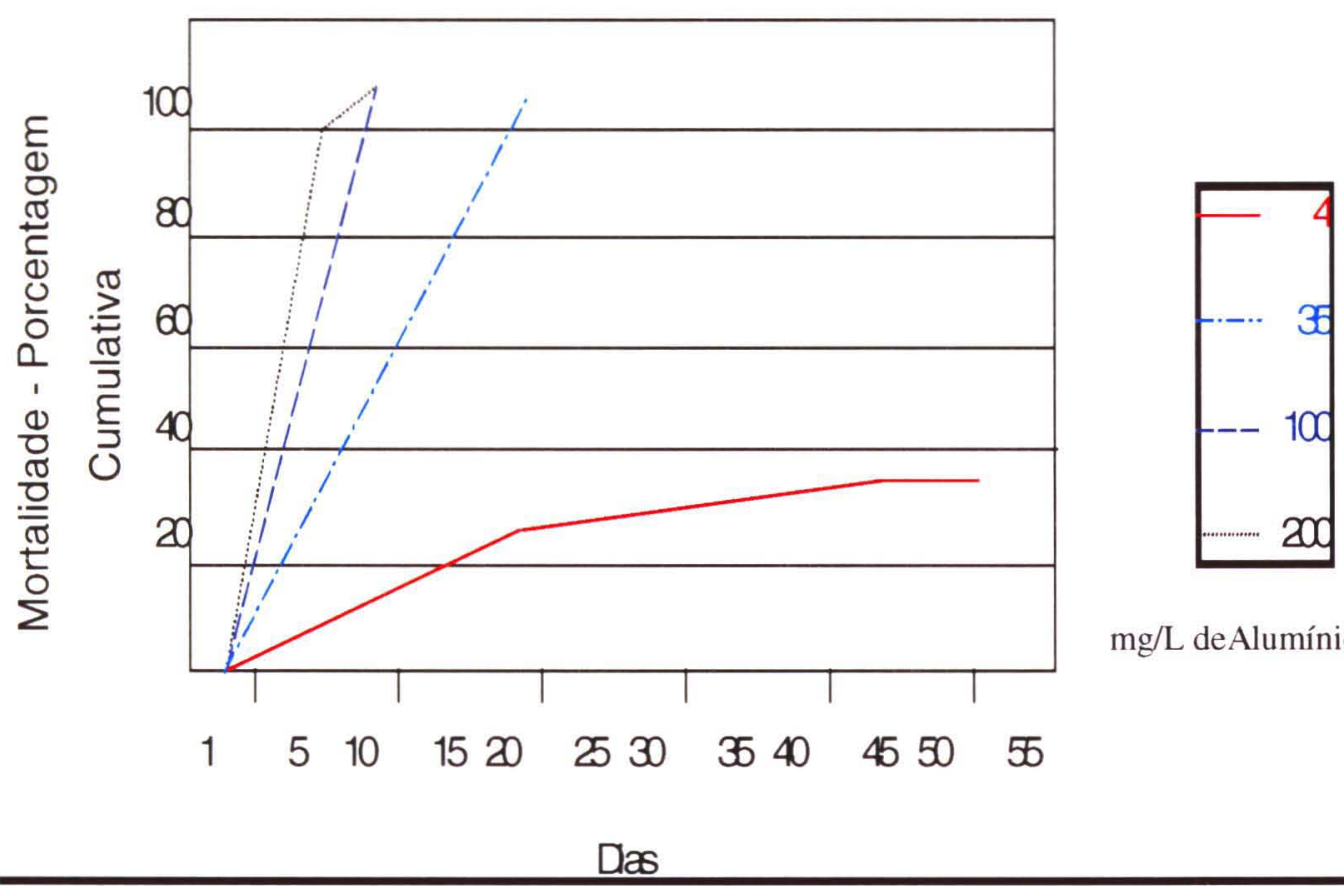

mg/L deAlumínio

Figura 4.1 Taxa de mortalidade de comunidades bentônicas invertebradas pela adição de lodos de sulfato de alumínio.

FONTE: LAMB \& BALLEY apud CORNWELL (1990)

MILLER et al (1984) apud CORDEIRO (1999), através de trabalhos realizados em 186 estações de tratamento de água nos Estados Unidos, demonstraram que a utilização de sulfato de alumínio como coagulante pode aumentar as concentrações de alumínio nas águas de abastecimento, acarretando além dos aspectos relativos à saúde:

> reduzir a efetividade da desinfecção da água;

> aumentar a turbidez da água tratada;

> provocar a deposição de alumínio nas paredes do tubo

No Brasil, a maioria das ETA's não possui instalações para disposição adequada desses lodos, lançando-os nos corpos d'água ou em galerias de águas pluviais. A figura 4.2 apresenta um esquema de produção de lodo de uma ETA convencional (TEIXEIRA 1999). 


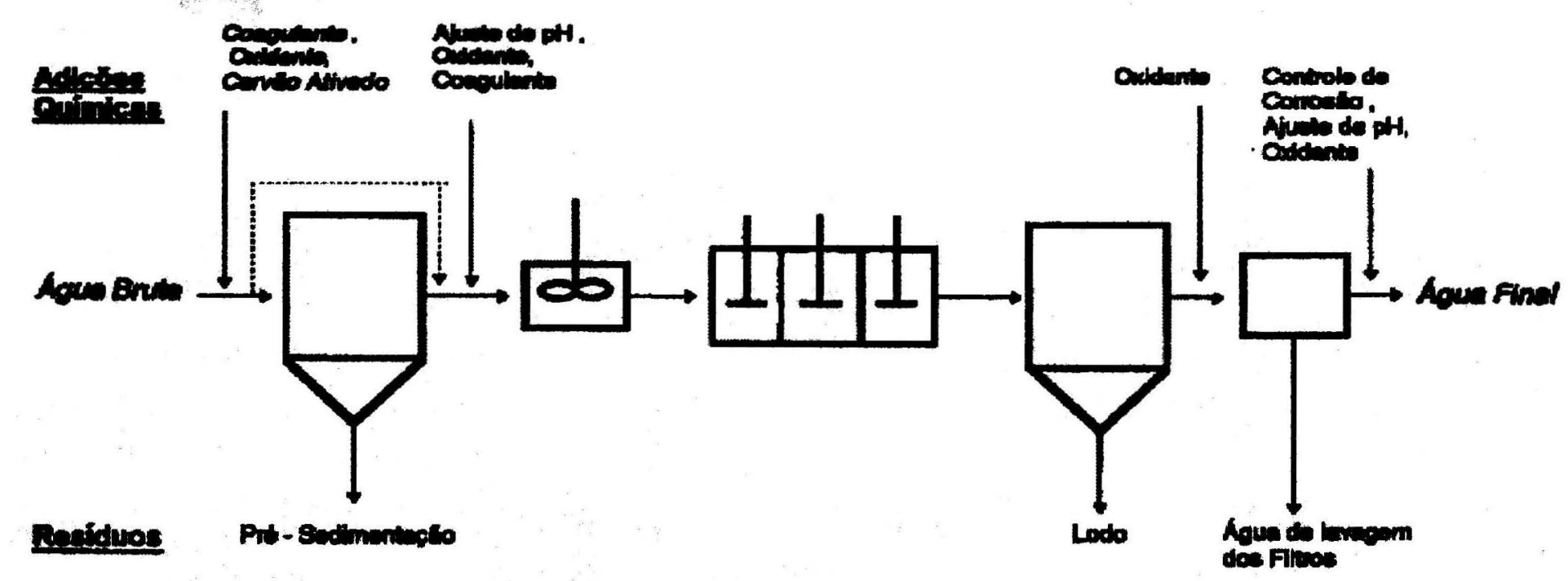

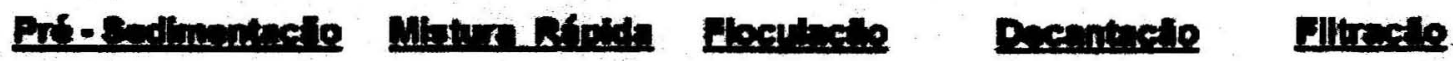

Figura 4.2 Esquema do processo de produção de lodo de uma ETA convencional

FONTE: AWWA (1987) apud TEIXIERA (1999) 


\subsection{Características dos lodos}

Ao contrário dos lodos de ETE's que contém grande parcela de matéria orgânica, gerando odor desagradável ao se decompor, os resíduos das ETA's são predominantemente inorgânicos. Tais resíduos são constituídos por: areia, argilas, siltes, ferro, manganês, compostos químicos resultantes da adição de coagulantes (hidróxidos de alumínio e ferro), microrganismos e material húmico removidos no processo de tratamento (FERNANDES 2002).

ELLIOT et al (1990) apud TEIXEIRA (1999), afirmam que esse resíduo sólido apresenta um teor de carbono total de 3\% e nitrogênio total de $0,6 \%$, valores esses inferiores aos encontrados em lodos de ETE's. Basicamente, os lodos de ETA's são inertes e suas taxas de mineralização de carbono e nitrogênio são similares ao do solo.

No caso da água bruta captada não apresentar alta concentração de material poluidor, os lodos de ETA's na maioria das vezes são estáveis e não putrescíveis, podendo ficar acumulados por dias ou até meses (AWWA 1971).

Devido à falta de conhecimento das características não tradicionais dos sólidos presentes no lodo (tamanho, distribuição das partículas, resistência específica e compressibilidade), além da variabilidade das características tradicionais apresentadas no quadro 4.2, CORDEIRO (1999), menciona que os problemas relacionados aos lodos gerados no tratamento de água necessitam ser equacionados de forma individualizada, demonstrando assim a grande diversidade entre as ETA's.

Ainda segundo o autor, pela falta de experiência em relação aos resíduos gerados em decantadores de ETA's completas, estima-se 
atualmente que cerca de 2000 toneladas de sólidos são lançados nos corpos receptores brasileiros sem nenhum tratamento.

Quadro 4.2 Características dos lodos gerados em ETA's.

\begin{tabular}{|c|c|c|c|c|c|c|}
\hline Autor/Ano & $\begin{array}{c}\text { DBO } \\
(\mathrm{mg} / \mathrm{L})\end{array}$ & $\begin{array}{c}\mathrm{DQO} \\
(\mathrm{mg} / \mathrm{L})\end{array}$ & pH & $\begin{array}{c}\text { ST } \\
\text { (mg/L) }\end{array}$ & $\begin{array}{c}\text { SV } \\
\% \text { ST }\end{array}$ & $\begin{array}{c}\text { SS } \\
\% \text { ST }\end{array}$ \\
\hline $\begin{array}{c}\text { Neubauer } \\
(1968)\end{array}$ & $\begin{array}{l}30 a \\
150\end{array}$ & $\begin{array}{c}500 \mathrm{a} \\
15.000\end{array}$ & $\begin{array}{c}6,0 \mathrm{a} \\
7,6\end{array}$ & $\begin{array}{c}1.100 \\
a \\
16.000\end{array}$ & $\begin{array}{c}20 a \\
30\end{array}$ & \\
\hline $\begin{array}{c}\text { Sutherland } \\
\text { (1969) }\end{array}$ & $\begin{array}{c}100 a \\
232\end{array}$ & 669 a 1100 & 7,0 & $\begin{array}{c}4.300 \\
a \\
14.000\end{array}$ & 25 & 80 \\
\hline $\begin{array}{l}\text { Bugg } \\
(1970)\end{array}$ & 380 & $\begin{array}{l}1.162 \mathrm{a} \\
15.800\end{array}$ & $\begin{array}{c}6,5 a \\
6,7\end{array}$ & $\begin{array}{c}4.380 \\
a \\
28.580\end{array}$ & 20 & \\
\hline $\begin{array}{c}\text { Albrecht } \\
\text { (1972) }\end{array}$ & $\begin{array}{l}30 a \\
100\end{array}$ & $\begin{array}{c}500 \mathrm{a} \\
10.000\end{array}$ & $\begin{array}{c}5,0 a \\
7,0\end{array}$ & $\begin{array}{c}3.000 \\
a \\
15.000\end{array}$ & 20 & 75 \\
\hline $\begin{array}{l}\text { Culp } \\
\text { (1974) }\end{array}$ & $\begin{array}{l}40 a \\
150\end{array}$ & $\begin{array}{l}340 \mathrm{a} \\
5.000\end{array}$ & 7,0 & & & \\
\hline $\begin{array}{l}\text { Nilsen } \\
\text { (1974) }\end{array}$ & 100 & 2.300 & & 10.000 & 30 & \\
\hline $\begin{array}{l}\text { Singer } \\
(1974)\end{array}$ & $\begin{array}{l}30 \mathrm{a} \\
300\end{array}$ & $\begin{array}{c}30 \mathrm{a} \\
5.000\end{array}$ & & & & \\
\hline $\begin{array}{c}\text { Cordeiro } \\
\text { (1981) }\end{array}$ & 320 & 5.150 & 6,5 & 81.575 & 20,7 & \\
\hline $\begin{array}{c}\text { Vidal } \\
(1990)\end{array}$ & 449 & 3.487 & $\begin{array}{c}6,0 \mathrm{a} \\
7,4\end{array}$ & 21.972 & 15 & \\
\hline $\begin{array}{c}\text { Cordeiro } \\
\text { (1993) }\end{array}$ & 173 & 5.600 & 6,4 & 30.275 & 26,3 & \\
\hline
\end{tabular}

FONTE: CORDEIRO (1993). 
FERNANDES (2002) comenta que, nos casos em que a água bruta apresentar alta concentração de sólidos em suspensão totais (SST) e, forem aplicados coagulantes a base de alumínio ou ferro, o lodo gerado apresentará alta porcentagem gelatinosa devido à precipitação dos hidróxidos $\left(\mathrm{Al}(\mathrm{OH})_{3}, \mathrm{Fe}(\mathrm{OH})_{3}\right)$, com características distintas mostradas no quadro 4.3.

Quadro 4.3 Características dos lodos gerados através do processo de coagulação com sais de alumínio ou ferro.

\begin{tabular}{|c|c|}
\hline TEOR DE SólIDOS & CARACTERÍSTICAS DO LODO \\
\hline $0-5 \%$ & líquido \\
\hline $8-12 \%$ & esponjoso, semi-sólido \\
\hline $1-25 \%$ & lama fina \\
\hline $40-50 \%$ & lama espessa \\
\hline
\end{tabular}

FONTE: ASCE (1990) apud FERNANDES (2002)

A tabela 4.5 apresenta algumas características dos lodos dos decantadores das ETA's da SABESP, localizadas na Região Metropolitana do Estado de São Paulo (RMSP). A tabela 4.6 mostra as características das águas residuárias de ETA's convencionais, que utilizaram sulfato de alumínio $\left[\mathrm{Al}_{2}\left(\mathrm{SO}_{4}\right)_{3}\right]$ como coagulante. 
Tabela 4.5 Características dos lodos dos decantadores das ETA's da RMSP.

\begin{tabular}{|c|c|c|c|c|c|c|c|}
\hline \multirow[b]{2}{*}{ Parâmetro } & \multirow[b]{2}{*}{ Unidade } & \multicolumn{6}{|c|}{ ETA } \\
\hline & & Guaraú & $\mathrm{ABV}$ & R. grande & R. Claro & T.A.R & A. Cotia \\
\hline Turbidez & $\overline{\text { UFT }}$ & 5.150 & 6.400 & 1.620 & 1.200 & 4.250 & 2.000 \\
\hline Cor & UC & 4.800 & 15.000 & - & 7.500 & 17.500 & 11.000 \\
\hline Ferro & $\mathrm{mg} / \mathrm{l}$ & 385 & 595 & 1.800 & 17,5 & 700 & 175 \\
\hline Oxigênio consumido & $\mathrm{mg} / \mathrm{l}$ & 600 & 1.060 & 2.625 & 1.450 & 2.800 & 1.040 \\
\hline Residuo totais & $\mathrm{mg} / \mathrm{l}$ & 9.193 & 14.178 & 12.750 & 5.490 & 20.096 & 5.309 \\
\hline Residuo voláteis & $\mathrm{mg} / \mathrm{l}$ & 72 & 158 & 462 & 155 & 173 & 213 \\
\hline Residuo involateis & $\mathrm{mg} / \mathrm{l}$ & 9.121 & 14.020 & 12.288 & 5.335 & 20.733 & 5.096 \\
\hline $\mathrm{pH}$ & - & 7,1 & 7,3 & 8,0 & 4,3 & 5,0 & 6,5 \\
\hline Alcalinidade & $\mathrm{mg} / \mathrm{l}$ & 5,0 & 10,0 & 115 & 0.0 & 0,0 & 11,0 \\
\hline
\end{tabular}

Obs: (1) Resultado da análise de uma amostra de um decantador de cada ETA

(2) Todas as ETAs possuem remoçăo manual de lodo dos decantadores, exceto ETA Guarau, cuja remoção e mecånica e contínua.

FONTE: YUZHU (1996).

Tabela 4.6 Características das águas residuárias de ETA's convencionais, usando $\left[\mathrm{Al}_{2}\left(\mathrm{SO}_{4}\right)_{3}\right]$ como coagulante.

\begin{tabular}{|c|c|c|c|c|c|c|c|c|}
\hline \multirow[t]{2}{*}{ Caracteristicas } & \multicolumn{4}{|c|}{ Lodos dos decantadores das estaçōes } & \multicolumn{4}{|c|}{$\begin{array}{c}\text { Água da lavagem de filtros } \\
\text { das estaçðes }\end{array}$} \\
\hline & $\bar{A}$ & $\mathrm{~B}^{*}$ & $\mathrm{C}$ & D & $\bar{A}$ & $\bar{B}$ & $\mathrm{C}$ & D \\
\hline $\mathrm{DBO}(\mathrm{mg} / \mathrm{l})$ & 41 & 90 & 108 & 44 & 4,2 & 3,7 & 2,8 & 1,8 \\
\hline $\mathrm{DQO}(\mathrm{mg} / \mathrm{l})$ & 540 & 2.100 & 15.500 & - & 28 & 75 & 160 & - \\
\hline $\mathrm{pH}$ & 7,1 & 7,1 & 6,0 & 6,0 & 7,8 & 7,8 & 7,8 & - \\
\hline Sólidos totais (mg/l) & 1.159 & 10.016 & 16.830 & - & 121 & 378 & 166 & $\cdot$ \\
\hline Sólidos voláteis $(\mathrm{mg} / \mathrm{l})$ & 571 & 3.656 & 10.166 & $\because$ & 44 & 115 & 45 & - \\
\hline $\begin{array}{l}\text { Sólidos em suspensão } \\
\text { totais (mg/l) }\end{array}$ & 1.110 & 5.105 & 19.044 & 15.790 & 47 & 104 & 75 & 100 \\
\hline $\begin{array}{l}\text { Sólidos em suspensáo } \\
\text { voláteis }(\mathrm{mg} / \mathrm{l})\end{array}$ & & 2.285 & 10.722 & 4.130 & 31 & 53 & 40 & 60 \\
\hline
\end{tabular}

* Utilizando carvão ativado

FONTE: YUZHU (1996). 


\subsection{Produção de lodo e balanço de massa}

Conforme FERREIRA FILHO (1996), em cada etapa dos processos unitários de tratamento de água, a produção de sólidos pode ser avaliada de várias maneiras. Nas estações em operação, a quantificação da produção de sólidos pode ser feita "in loco", monitorando-se cada fase do processo durante um espaço de tempo em que, sejam verificadas alterações da qualidade da água bruta $\Theta$ características do tratamento como: tipo e dosagem de coagulante, $\mathrm{pH}$ de coagulação, etc.

Em estações em fase de projeto, a quantificação dos resíduos gerados pode ser calculado através de fómulas empíricas e adoção de eficiências relativas a cada processo ou operação unitária para posterior cálculo do balanço de massa. (FERNANDES 2002)

Segundo REALI (1999), para uma melhor avaliação da produção de lodo gerado nas ETA's, é necessária a estimativa de dois parâmetros importantes:

$>$ a massa de sólidos secos presentes no lodo resultante do processo de tratamento;

$>$ o volume de água descartada que atua como veículo da massa de sólidos.

O autor menciona ainda que, o primeiro parâmetro pode ser obtido efetuando-se o balanço de massa do sistema, primeiramente avaliandose quais os sólidos deverão aparecer como resíduo. A seguir, pode-se calcular estequiometricamente os resíduos resultantes da aplicação do coagulante químico. No quadro 4.4 são apresentados alguns resíduos encontrados nas estações de tratamento de água. 
Quadro 4.4 Resíduos encontrados durante os processos de tratamento de água.

\begin{tabular}{|c|c|c|c|}
\hline $\begin{array}{l}\text { Produto } \\
\text { Químico }\end{array}$ & $\begin{array}{c}\text { Proveniente } \\
\text { de }\end{array}$ & $\begin{array}{l}\text { Aparece no } \\
\text { resíduo como: }\end{array}$ & Sólido \\
\hline $\begin{array}{c}\text { Sólidos } \\
\text { dissolvidos }\end{array}$ & Água bruta & Sólidos dissolvidos & $\begin{array}{l}\text { Somente se } \\
\text { precipitados }\end{array}$ \\
\hline $\begin{array}{c}\text { Sólidos } \\
\text { suspensos } \\
\text { (silte) }\end{array}$ & Água bruta & Silte sem mudança & Sim \\
\hline $\begin{array}{l}\text { Matéria } \\
\text { orgânica }\end{array}$ & Água bruta & $\begin{array}{c}\text { Provavelmente sem } \\
\text { mudança }\end{array}$ & Sim \\
\hline $\begin{array}{l}\text { Sais de } \\
\text { alumínio }\end{array}$ & $\begin{array}{l}\text { Coagulação. } \\
\text { química }\end{array}$ & $\begin{array}{l}\text { Hidróxido de } \\
\text { alumínio }\end{array}$ & Sim \\
\hline Sais de ferro & $\begin{array}{c}\text { Coagulação. } \\
\text { química }\end{array}$ & Hidróxido de ferro & Sim \\
\hline Polímeros & $\begin{array}{l}\text { Tratamento } \\
\text { químico }\end{array}$ & Sem mudança & Sim \\
\hline Cal & $\begin{array}{c}\text { Tratamento } \\
\text { químico e } \\
\text { correção de pH }\end{array}$ & $\begin{array}{l}\text { Ou carbonato de } \\
\text { cálcio ou, se for } \\
\text { usado solução de } \\
\text { cal, somente } \\
\text { impurezas. }\end{array}$ & Sim \\
\hline $\begin{array}{c}\text { Carvão ativado } \\
\text { em pó }\end{array}$ & $\begin{array}{l}\text { Controle de } \\
\text { sabor } \theta \text { odor }\end{array}$ & $\begin{array}{c}\text { Carvão ativado em } \\
\text { pó }\end{array}$ & Sim \\
\hline Cloro, ozônio. & Desinfecção & Em solução & Não \\
\hline
\end{tabular}

FONTE: REALI (1996)

A partir de fórmulas empíricas propostas por NIELSEN et al (1973) apud REALI (1996), foram determinados os valores teóricos da produção 
de sólidos devido à introdução de diversos produtos químicos na água. Os valores dessas frações são apresentados no quadro 4.5

Quadro 4.5 Valores teóricos da produção de sólidos.

\begin{tabular}{|c|c|}
\hline Produtos Químicos & $\begin{array}{c}\text { g de Sólidos produzidos por } \\
\text { g de produto químico }\end{array}$ \\
\hline Sólidos suspensos (silte) & 1,0 \\
\hline Matéria orgânica & 1,0 \\
\hline Sulfato de alumínio & 0,26 como Al(OH)3 \\
\hline Cloreto férrico & 0,66 como Fe(OH)3 \\
\hline Polímero & 1,0 \\
\hline Cal & 0,1 como fração insolúvel \\
\hline Carvão ativado em pó & 1,0 \\
\hline
\end{tabular}

FONTE: REALI (1996)

Ao assumir, segundo FERREIRA FILHO (1996), que o residual de alumínio e ferro na água sejam despreziveis, a produção de sólidos, utilizando-se sais de alumínio e ferro pode ser estimada segundo as expressões 4.1 e 4.2 respectivamente.

$$
\begin{aligned}
& P_{L}=Q .\left(4,89^{*} D_{A l}+S S+C A P+O A\right)^{*} 10^{-3} \\
& P_{L}=Q .\left(2,88^{*} D_{F_{O}}+S S+C A P+O A\right)^{*} 10^{-3}
\end{aligned}
$$

Existem ainda outras equações que podem ser usadas para estimativas da quantidade de lodo produzida. O quadro 4.6 mostra algumas dessas equações. Para facilitar o uso das equações, pode-se substituir o parâmetro SST por turbidez, pois na maioria das vezes tais dados não estão disponíveis (TEIXEIRA 1999). 
Quadro 4.6 Equações empíricas usadas para o cálculo da quantidade de lodo produzida em uma ETA.

\begin{tabular}{c|l}
\hline \multicolumn{1}{|c}{ Equação } & \multicolumn{1}{|c}{ Fonte } \\
\hline $\mathrm{PL}=86400 \cdot 3,5 \cdot 10^{-3} \cdot \mathrm{T}^{0,66} \cdot \mathrm{Q}^{*}$ & AWWA, 1978 \\
\hline $\mathrm{PL}=86400 \cdot \mathrm{Q} \cdot(\mathrm{SS}+0,07 \mathrm{C}+\mathrm{H}+\mathrm{A}) \cdot 10^{-3}$ & W.R.C, 1979 \\
\hline $\mathrm{PL}=86400 \cdot \mathrm{Q} \cdot\left(0,23 \cdot \mathrm{D}_{\mathrm{Al}}+1,5 \mathrm{~T}\right) \cdot 10^{-3}$ & CETESB, apud Teixeira \\
\hline $\mathrm{PL}=86400 \cdot \mathrm{Q} \cdot\left(0,44 \cdot \mathrm{D}_{\mathrm{A}}+1,5 \mathrm{~T}+\mathrm{A}\right) \cdot 10^{-3}$ & CORNWELL apud Teixeira \\
\hline $\mathrm{PL}=86400 \cdot \mathrm{Q} \cdot(\mathrm{SS}+\mathrm{XC}+\mathrm{KD}+\mathrm{a}+\mathrm{Fi}+\mathrm{Mi}+\mathrm{Ci}) \cdot 10^{-3}$ & AFEE, 1982 \\
\hline
\end{tabular}

FONTE: TEIXEIRA (1999).

$P_{L}=$ produção de sólidos seco em $\mathrm{kg} /$ dia $\left(\mathrm{M} \mathrm{T}^{-1}\right)$,

$Q=$ vazão de água bruta em $\mathrm{m}^{3} /$ dia $\left(\mathrm{L}^{3} \mathrm{~T}^{-1}\right)$,

$Q^{*}$ = vazão de água bruta em $\mathrm{m}^{3} / \mathrm{S}\left(\mathrm{L}^{3} \mathrm{~T}^{-1}\right)$,

$D_{A l}=$ dosagem de sais de alumínio, expresso como $A l$ em $\mathrm{mg} / \mathrm{L},\left(\mathrm{ML}^{-3}\right)$,

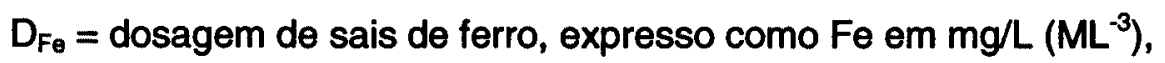

SS = concentração de sólidos em suspensão totais na água bruta em $\mathrm{mg} / \mathrm{L}\left(\mathrm{M} . \mathrm{L}^{-3}\right)$,

CAP = concentração de carvão ativado em pó em $\mathrm{mg} / \mathrm{L}\left(M \cdot L^{-3}\right)$.

$\mathrm{OA}=$ outros aditivos em $\mathrm{mg} / \mathrm{L}$ (silica ativada, polímeros, etc...) $\left(M . \mathrm{L}^{-3}\right)$.

$\mathrm{T}=$ turbidez da água bruta (UNT)

$\mathrm{C}=$ cor da água bruta (UC)

$\mathrm{H}=$ dosagem de coagulante em $\mathrm{mg} / \mathrm{l}(\mathrm{ML}-3)$

$x=$ coeficiente para converter cor em sólidos $(0,05$ a 0,07$)$

$k=$ coeficiente de precipitação: sulfato de alumínio líquido $=0,17 \Theta$ cloreto férrico líquido $=0,39$

$\mathrm{Fi}=$ massa de precipitado de hidróxido de ferro devido a remoção de ferro em $\mathrm{mg} / \mathrm{l}\left(\mathrm{ML}^{-3}\right)$

Mi = massa de precipitado de óxido de manganês devido a remoção de manganês em $\mathrm{mg}^{\prime} /\left(\mathrm{ML}^{-3}\right)$ 
Nas ETA's em fase de projeto, a realização de ensaios de "jar test" em escala de laboratório demonstra ser um importante instrumento na determinação da quantidade de coagulantes a serem utilizados, otimizando o desempenho do processo de tratamento, assim como, na determinação da produção de sólidos. A figura 4.3 mostra a correlação entre sólidos em suspensão e turbidez, para uma fonte de água bruta com baixa cor (FERNANDES 2002).

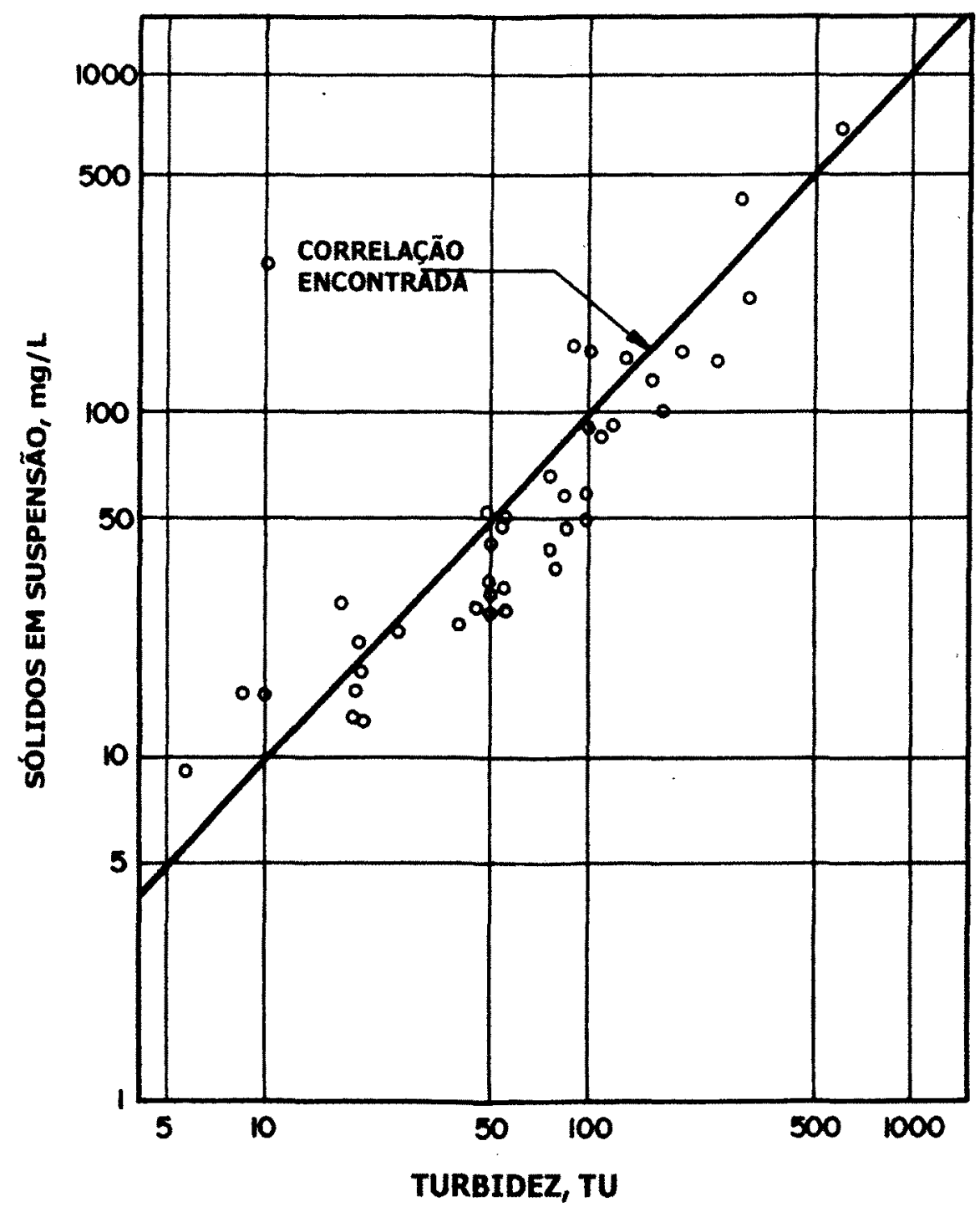

Figura 4.3 Correlação entre sólidos em suspensão e turbidez para uma fonte de água bruta com baixa cor.

FONTE: AWWARF (1987) apud FERNANDES (2002) 
A partir dos parâmetros apresentados no quadro 4.7 é possível efetuar um balanço de massa para uma ETA genérica. Utilizando-se como coagulante o sulfato de alumínio, pode-se calcular a produção de lodo gerada no sistema.

Quadro 4.7 Parâmetros utilizados para a elaboração de um balanço de massa genérico para um sistema de tratamento de água.

\begin{tabular}{l|c}
\hline Vazão ( $\left.\mathrm{m}^{3} / \mathrm{s}\right)$ & 1,9 \\
\hline Coagulante & $\begin{array}{c}\text { Sulfato de } \\
\text { alumínio }\end{array}$ \\
\hline Dosagem de coagulante (mg/l) Alta turbidez & 28,0 expresso \\
como \\
$\mathrm{Al}_{2}\left(\mathrm{SO}_{4}\right)_{3} .14 \mathrm{H}_{2} \mathrm{O}$
\end{tabular}

FONTE: FERREIRA FILHO (1996) 
Efetuando-se o balanço de massa até que ocorra o seu fechamento completo, obtêm-se as vazões líquidas e sólidas de projeto para a situação de água bruta com recirculação integral da água de lavagem sem separação de sólidos. $O$ balanço de massa completo encontra-se apresentado na figura 4.4.

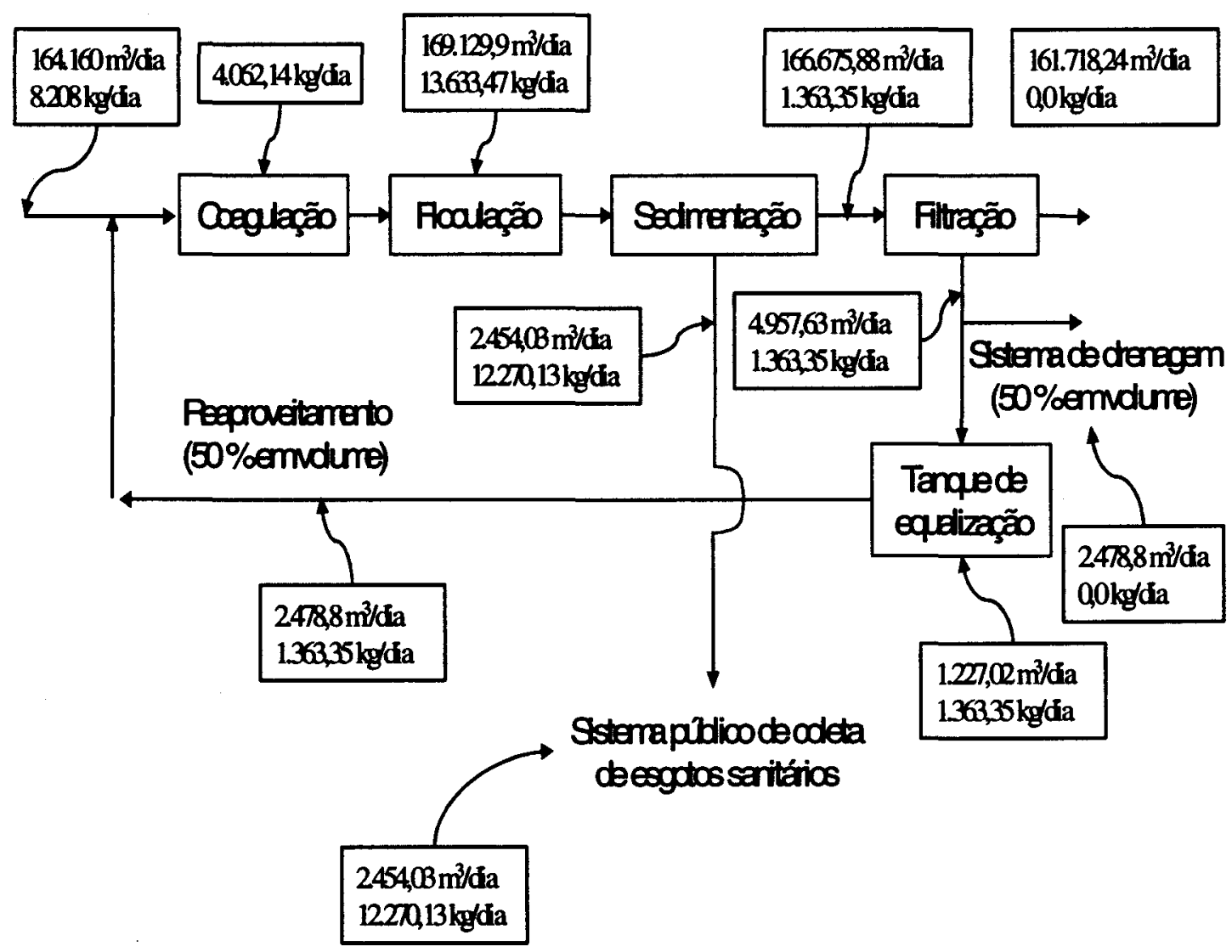

Figura 4.4 Balanço de massa. Reciclagem integral da água de lavagem sem separação de sólidos para a ETA genérica.

FONTE: FERREIRA FILHO (1996) 


\section{TRATAMENTO DE ESGOTO}

A palavra esgoto costumava ser empregada para caracterizar a tubulação condutora de águas servidas como também o próprio líquido que escoa por essas canalizações. Hoje esse termo é amplamente utilizado para caracterizar os despejos provenientes das diversas modalidades de usos e origem das águas, tais como: usos domésticos, industriais, agrícolas e de infiltração na rede coletora. (JORDÃO e PESSOA 1995).

Conforme METCALF \& EDDY (2003), como resultado da decomposição da matéria orgânica, os esgotos sanitários quando dispostos sem os devidos tratamentos podem causar vários inconvenientes e efeitos indesejáveis, como por exemplo: a formação de gases com odores desagradáveis. Além do mais, os esgotos não tratados possuem grandes quantidades de microorganismos patogênicos, nutrientes que criam condições favoráveis para 0 crescimento de algas e compostos tóxicos ou potencialmente carcinogênicos que comprometem a saúde da população e os recursos hídricos.

O objetivo principal do tratamento de esgoto é melhorar as suas características, de tal maneira que, o seu uso e disposição final possam ocorrer com regras e critérios definidos pelas autoridades legislativas (VAN HAANDEL e LETTINGA 1994 apud NAVAL 2001).

Para se atingir a qualidade desejada ou os padrões vigentes de qualidade, os efluentes estão condicionados a niveis de tratamento comumente denominados processos de tratamento. No Brasil são empregados os seguintes tratamentos: preliminar, primário, secundário $\theta$ raramente terciário (VON SPERLING 1996). 
Para se conhecer o grau de poluição de uma água residuária, dimensionar as ETE's e avaliar sua eficiência é importante que se quantifique a matéria orgânica presente no esgoto, indicada pela determinação da DBO. Quanto maior a poluição orgânica, maior a DBO, paralelamente, ao ocorrer à estabilização da matéria orgânica, menor será o valor da DBO (PAGANINI 1997).

Os despejos domésticos são constituidos por uma elevada porcentagem de água, cerca de 99,9\%, e apenas $0,1 \%$ de sólidos suspensos, coloidais e dissolvidos. Esta pequena fração é que apresenta os maiores problemas no tratamento e disposição final, conforme figura 5.1 (MENDONÇA 2000).

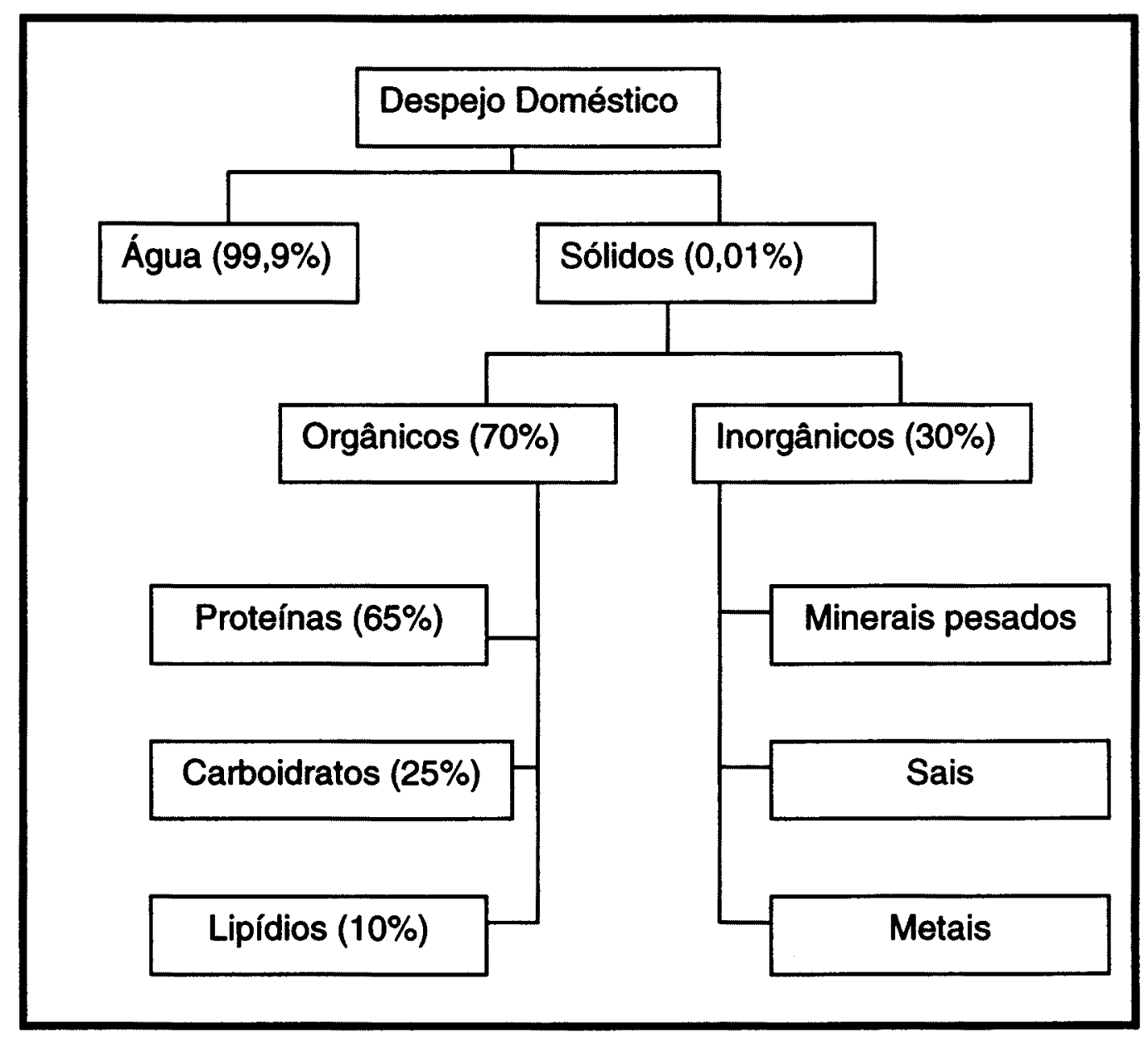

Figura 5.1 Composição geral dos despejos domésticos.

FONTE: MENDONÇA (2000). 
Dependendo da concentração dos sólidos presentes nos esgotos domésticos, os despejos líquidos podem ser classificados como: forte, médio e fraco, conforme quadro 5.1(METCALF \& EDDY 2003).

Quadro 5.1 Classificação dos esgotos sanitários domésticos.

\begin{tabular}{|c|c|c|c|c|}
\hline \multirow[t]{2}{*}{ Parâmetro } & \multirow[t]{2}{*}{ Unidade } & \multicolumn{3}{|c|}{ Concentração } \\
\hline & & Forte & Médio & Fraco \\
\hline Sólidos Totais & $\mathrm{mg} / \mathrm{L}$ & 1200 & 720 & 250 \\
\hline Sólidos Dissolvidos Totais & $\mathrm{mg} / \mathrm{L}$ & 850 & 500 & 150 \\
\hline Sólidos Dissolvidos Fixos & $\mathrm{mg} / \mathrm{L}$ & 525 & 300 & 145 \\
\hline Sólidos Dissolvidos Voláteis & $\mathrm{mg} / \mathrm{L}$ & 325 & 200 & 105 \\
\hline Sólidos Suspensos Totais & $\mathrm{mg} / \mathrm{L}$ & 350 & 220 & 100 \\
\hline Sólidos Suspensos Fixos & $\mathrm{mg} / \mathrm{L}$ & 75 & 55 & 20 \\
\hline Sólidos Suspensos Voláteis & $\mathrm{mg} / \mathrm{L}$ & 275 & 165 & 80 \\
\hline Sólidos Sedimentáveis & $\mathrm{mg} / \mathrm{L}$ & 20 & 10 & 5 \\
\hline $\begin{array}{l}\text { Demanda Bioquímica de } \\
\text { Oxigênio }\end{array}$ & $\mathrm{mg} / \mathrm{L}$ & 400 & 220 & 110 \\
\hline $\begin{array}{l}\text { Demanda Química } \quad \text { de } \\
\text { Oxigênio }\end{array}$ & $\mathrm{mg} / \mathrm{L}$ & 1000 & 500 & 250 \\
\hline Nitrogênio Total & $\mathrm{mg} / \mathrm{L}$ & 85 & 40 & 20 \\
\hline Nitrogênio orgânico & $\mathrm{mg} / \mathrm{L}$ & 35 & 15 & 8 \\
\hline Nitrogênio amoniacal & $\mathrm{mg} / \mathrm{L}$ & 50 & 25 & 12 \\
\hline Fósforo Total & $\mathrm{mg} / \mathrm{L}$ & 15 & 8 & 4 \\
\hline Coliformes totais & NMP/100mL & $\begin{array}{c}10^{7} \mathrm{a} \\
10^{9}\end{array}$ & $10^{7}$ a $10^{8}$ & $10^{6}$ a $10^{7}$ \\
\hline
\end{tabular}

FONTE: METCALF \& EDDY (2003)

Segundo JORDÃO e PESSOA (1995), geralmente as instalações de tratamento são classificadas em função do grau de redução dos sólidos em suspensão (SS) e da demanda bioquímica de oxigênio (DBO), proveniente da eficiência de uma ou mais unidades de tratamento, apresentados no quadro 5.2 . 
Quadro 5.2 Tipos de tratamentos em função eficiência das unidades.

\begin{tabular}{|c|l|}
\hline Tratamento preliminar & $\begin{array}{l}\text { Remoção de sólidos grosseiros, } \\
\text { gorduras e areias }\end{array}$ \\
\hline Tratamento primário & $\begin{array}{l}\text { Sedimentação, } \\
\text { Flotação, } \\
\text { Digestão de lodo, } \\
\text { Secagem de lodo, } \\
\text { Sistemas compactos (Tanque Imhoff), } \\
\text { Sistemas anaeróbios (lagoa anaeróbia, } \\
\text { reator fluxo ascendente). }\end{array}$ \\
\hline Tratamento secundário & $\begin{array}{l}\text { Filtração biológica, } \\
\text { Processo de lodos ativados, } \\
\text { lagoas de estabilização (facultativa, } \\
\text { aerada) }\end{array}$ \\
\hline Tratamento terciário & $\begin{array}{l}\text { Lagoas de maturação, } \\
\text { Desinfecção, } \\
\text { Processos de remoção de nutrientes e } \\
\text { Filtração final }\end{array}$ \\
\hline
\end{tabular}

FONTE: adaptado JORDÃO e PESSOA (1995) 


\subsection{Organismos presentes no esgoto}

As bactérias são organismos pluricelulares que se apresentam isoladamente ou em agregados, formando colônias sob várias formas (filamentosas, cachos de uva). A célula possui tamanhos variáveis, entre 0,5 e 25 micra, de forma esférica, bastonete, espiralada, apresentando ou não flagelos para sua locomoção (BRANCO 1986).

Sua reprodução ocorre por simples divisão ou formação de esporos, as colônias são formadas quando as células da divisão permanecem agregadas umas às outras. Existem na natureza bactérias de nutrição autotrófica $e$ as de nutrição heterotrófica, podendo ser de vida parasitária, saprofítica ou simbiôntica.

Quanto à respiração, existem as estritamente aeróbias, as anaeróbias $\theta$ aquelas que sobrevivem em ambos ambientes, chamadas bactérias facultativas.

Do ponto de vista hidrobiológico, demonstram algum interesse apenas bactérias coliformes e saprófitas de vida livre que habitam as águas puras ou poluídas.

As bactérias habitantes do intestino humano ou de animais homeotermos são as do grupo coli que, vivendo saprofiticamente, não causam danos aos seus hospedeiros. Tem grande valor para os sanitaristas, pois sua presença na água indica contaminação por fezes ou por esgoto doméstico.

Neste grupo, podem ser citadas as do gênero Escherichia e sua presença é identificada por meio de culturas especiais, distinguindo-se de outras bactérias intestinais por fermentarem a lactose do meio de cultura, produzindo gás, ao contrário das bactérias patogênicas (salmonelas e shigelas) (BRANCO 1986). 
Ainda segundo BRANCO (1986), admite-se que toda água que contenha mais que um ou dois bacilos do grupo coli em cada cem centímetros cúbicos, pode conter bactérias patogênicas, sendo necessárias desinfecções antes de seu consumo.

As bactérias podem ser consideradas como organismos de nutrição saprofítica $\Theta$ autotrófica, sendo estes últimos, quimiossintetizantes ou fotossintetizantes.

As bactérias quimiotróficas são aquelas que sintetizam compostos orgânicos a partir de gás carbônico $\theta$ água, utilizando-se como fonte de energia, as calorias provenientes da oxidação de compostos inorgânicos existentes no meio em que vivem.

As quimiotróficas são ainda constituídas por grupos de acordo com o substrato ou elemento químico sobre a qual reagem, conforme Quadro 5.3.

Quadro 5.3: Alguns Grupos de Bactérias Quimiotróficas.

\begin{tabular}{|l|l|}
\hline \multicolumn{1}{|c|}{ Bactérias } & \multicolumn{1}{c|}{ Reação Simplificada } \\
\hline Hidrogenobactérias & $\mathrm{H}_{2}+1 / 2 \mathrm{O}_{2}$ \\
\hline Ferrobactérias & $4 \mathrm{Fe} \mathrm{CO}_{3}+\mathrm{O}_{2}+6 \mathrm{H}_{2} \mathrm{O}+56 \mathrm{kcal}$ \\
\hline Sulfobactérias & $\mathrm{H}_{2} \mathrm{~S}+1 / 2 \mathrm{O}_{2}(\mathrm{OH})_{3}+4 \mathrm{CO}_{2}+40 \mathrm{kcal}$ \\
\hline Nitrobactérias & $\mathrm{NH}_{4}+11 / 2 \mathrm{O}_{2} \mathrm{H}+41 \mathrm{kcal}$ \\
\hline Nitrobactérias & $\mathrm{NO}_{2}+1 / 2 \mathrm{H}_{2} \mathrm{O}+\mathrm{NO}_{2}+66 \mathrm{kcal}$ \\
\hline
\end{tabular}

FONTE: BRANCO (1986). 


\subsection{Lagoas de estabilização}

\subsubsection{Histórico}

Nas cidades européias desde 1900, especificamente em Estrasburgo, os sistemas de tratamento secundários idealizados por Hofer tinham como objetivo principal realizar em tanques retangulares os processos naturais de degradação da matéria orgânica ocorridos nos cursos d'água. Primeiramente, os esgotos eram tratados em decantadores e os materiais sedimentáveis retirados, eram tratados anaerobicamente. Após diluição com adição da água do rio, o efluente líquido era lançado em quatro tanques, também eram adicionados animais, tais como: micro-crustáceos, larvas de insetos, moluscos e vegetais enraizados no fundo. No último desses tanques foram colocadas carpas que se alimentavam dos microorganismos que se desenvolviam nesse meio. Verificou-se um aumento de massa desses peixes $\theta$, os resultados mostraram redução de $92,5 \%$ no número de bactérias, $78 \%$ no nitrogênio e $80 \%$ de demanda de oxigênio, além disso, o efluente era límpido com um O.D. variando de 5 a $7 \mathrm{mg} / \mathrm{L}$. Essa pesquisa foi realizada com uma superfície de água equivalente a um hectare para cada 200 habitantes (BRANCO 1986).

Provavelmente por volta de 1901, segundo SMALLHORST (1960), com o objetivo de utilizar o efluente na irrigação, uma lagoa de armazenamento de esgoto com aproximadamente 280 ha foi construida na cidade de San Antonio, Texas. Hoje em dia esse lago é conhecido como lago Mitchell (VICTORETTI 1964).

Entretanto JORDÃO e PESSOA (1995), comentam que, acidentalmente os primeiros fenômenos biológicos no tratamento de esgoto constatados em lagoas foram em Santa Rosa (EUA, 1924) e Fesseden, Dakota do Norte (EUA, 1928). Nessa época, faltavam estudos completos quanto às formas geométricas (largura, comprimento $e$ 
profundidade) e dados gerais como: DBO, tempo de detenção hidráulica, número de pessoas por hectare. Em Fesseden, com a falta de um sistema de tratamento e corpo receptor adequados, os esgotos eram direcionados para uma depressão no terreno fora da cidade. Alguns meses depois foi constatado que a qualidade do efluente final era comparável a de um tratamento secundário, permanecendo assim em operação por trinta anos.

Durante a Segunda Guerra Mundial, devido à escassez de materiais e equipamentos adequados para dispor os resíduos líquidos, as autoridades americanas tiveram que adotar soluções mais rápidas e ao mesmo tempo eficazes. Foram então projetadas e construídas as lagoas denominadas de: lagoas de oxidação. Em 1946 foram publicados resultados completos de operação nas bases de Camp Houd e Camp Barkeley, Texas e Shoemaker Naval Station na Califórnia (AZEVEDO NETTO 1967).

$\mathrm{Na}$ tentativa de se encontrar parâmetros confiáveis para dimensionamento e melhor acompanhamento dessas lagoas, projetos foram desenvolvidos com objetivos e critérios racionais, tomando por base: a carga de matéria orgânica, tempo de detenção hidráulico, profundidade, número de habitantes e tipo de efluentes. Por volta do ano de 1948, nos EUA, entrou em operação a primeira lagoa projetada para tratamento de efluentes, a lagoa de Maddock. Nessa mesma época, na Austrália, foram desenvolvidos estudos de lagoas em série, surgindo assim outra derivação desse tipo de tratamento conhecido no Brasil como "Sistema Australiano", lagoa anaeróbia seguida por uma lagoa facultativa (VICTORETTI 1964).

Ainda segundo o autor, a partir de uma parceria entre a Prefeitura de São José dos Campos, Departamento de Águas e Energia Elétrica e - Serviço de Especial de Saúde Pública, com a finalidade de se conhecer a aplicação desse sistema $\theta$ obter parâmetros para dimensionamento em função das características e das condições 
brasileiras, em 1957, foi construído o primeiro sistema de lagoas de estabilização na região do Vale do Paraíba.

\subsubsection{Conceito de lagoas de estabilização}

Diversos autores empregam várias denominações para esse tipo de tratamento: Lagoas de Esgoto, Lagoas de Oxidação, Lagoas Redox e Lagoas de Depuração, porém hoje o termo que vem sendo mais utilizado é Lagoa de Estabilização.

\subsubsection{Definição}

Existem várias definições para lagoas de estabilização: “... tanques construídos de terra, de profundidade reduzida $(<5,00 \mathrm{~m})$, projetados para tratamento de águas residuárias, pela interação da biomassa (algas, bactérias, protozoários, etc.), da matéria orgânica do esgoto e outros processos naturais. A finalidade deste processo é obter um efluente com várias características definidas (DBO, DQO, OD, SS, algas, nutrientes, parasitas, enterobactérias, coliformes, etc)..." (YÁNEZ 1993).

“... constituem um processo biológico de tratamento de águas residuárias que se caracterizam pela simplicidade, eficiência e baixo custo" (MATSHUSITA s.d.)

“... são os mais simples métodos de tratamento de esgoto que existem. São constituídas de escavações rasas cercadas por taludes de terra, com forma retangular ou quadrada..." (MENDONÇA 1995).

De uma forma geral, os sistemas de lagoas de estabilização se resumem na forma mais simples do tratamento biológico, onde a estabilização da matéria orgânica é realizada pela oxidação bacteriológica e lou redução fotossintética das algas (JORDÃO e PESSOA 1995). 
Por não necessitar de operadores qualificados e equipamentos sofisticados, as lagoas de estabilização vêm sendo empregadas com sucesso em países em desenvolvimento e de climas tropicais, onde os recursos financeiros são precários e os custos investidos em sistemas convencionais são elevados. (NAVAL 2001).

Como todos os processos de tratamento, os sistemas de lagoas de estabilização apresentam vantagens e desvantagens (KELLNER 1998).

As principais vantagens são:

$>$ grandes facilidades na construção;.

$>$ simplicidade de operação e manutenção;

$>$ baixo custo de operação e manutenção;

$>$ não necessita de mão de obra especializada;

$>$ alta qualidade do efluente final, com significativa redução de patógenos;

$>$ grande capacidade de absorver choques hidráulicos $\theta$ orgânicos devido aos altos tempos de detenção.

$>$ utilizam pouca energia elétrica.

As principais desvantagens são:

$>$ necessidades de grandes áreas;

$>$ às vezes, sua operação e manutenção acabam sendo desprezadas por não necessitar de pessoal especializado

$>$ exalação de odores desagradáveis (lagoas anaeróbias),

$>$ dependências de fatores climáticos.

No processo de depuração das lagoas, as condições biológicas e hidráulicas podem ser afetadas por fenômenos meteorológicos, variáveis locais relacionadas com intensidade luminosa e fenômenos hidrológicos. Neste caso, são considerados fenômenos naturais incontroláveis, pois 
não se pode exercer qualquer ação para modificá-los (MENDONÇA 2000).

\subsection{Fenômenos naturais incontroláveis}

$>\quad$ Evaporação: pode provocar redução na lâmina d'água, propiciando desenvolvimento de vegetações emergentes e diminuição do tempo de detenção, modificando o equilíbrio hidráulico, alterando a concentração de sólidos da matéria orgânica, além de produzir um aumento da salinidade do meio, provocando modificações osmóticas do material celular contribuindo de maneira significativa no equilíbrio biológico.

$>$ Radiação solar: é extremamente indispensável na produção de oxigênio e influi diretamente na reação de fotossíntese. A quantidade de luz solar auxilia também na determinação da área e profundidade necessárias para uma boa operação.

$>$ Precipitaçōes pluviométricas: dependendo da sua duração e intensidade, a presença de águas pluviais nas redes coletoras sempre provoca diluição das águas residuárias, diminuição do tempo de detenção, arrastes da população de algas, acarretando em redução do rendimento da lagoa.

$>\quad$ Ventos: a formação de ondas causadas pelo vento pode provocar erosão nos taludes internos mínimos e máximos de operação. Além disso, favorecem a homogeneização da lagoa da massa líquida e contribuem na oxigenação da lagoa, aumentando a superfície de contato das partículas de água com a atmosfera, auxiliando também no transporte das algas imóveis para zonas mais fundas da lagoa.

$>\quad$ Nuvens: são elementos capazes de se interpor quanto à passagem de radiação solar. 


\subsubsection{Classificação e princípios biológicos das lagoas de estabilização}

Existem várias maneiras de se classificar as lagoas de estabilização. De acordo com a quantidade de oxigênio, podem ser: anaeróbicas, aeróbicas e facultativas. São denominadas lagoas aeradas quando a aeração é feita artificialmente. Segundo YANEZ (1993), conforme a disposição que se encontrem em relação às unidades de tratamento, as lagoas podem ainda ser classificadas como: primárias quando recebem esgoto bruto e secundárias quando recebem efluentes de outras unidades de tratamento e de maturação se o objetivo fundamental visa reduzir organismos patogênicos.

\subsection{Princípios da respiração e fotossíntese}

Em meados do século XVIII, através de pesquisas, Joseph Priestley verificou que tanto um camundongo quanto uma planta quando colocados separadamente em compartimentos de vidro morriam após algumas horas, mas sobreviviam quando colocados juntos na presença de luz. Este estudo demonstrou o princípio de equilíbrio biológico que ocorre entre seres heterótrofos e seres autótrofos: respiração e fotossintese (BRANCO 1967). O sistema de lagoas de estabilização baseia-se nesses dois princípios biológicos.

Conforme BRANCO (1986), a respiração é um fenômeno universal realizado por organismos do reino animal e vegetal que, consiste na oxidação de substâncias de estruturas mais complexas com alta energia potencial, posteriormente utilizada na realização de suas atividades vitais ou ações que consumam calorias. A respiração dos organismos é dividida em aeróbia e anaeróbia.

$\mathrm{Na}$ respiração dos organismos aeróbios, a maior parte da matéria orgânica consumida é transformada em glicose, através do processo de 
digestão química, processo que tem como objetivo, reduzir as partículas através da fragmentação das moléculas que compõem a massa, originando partículas mais simples $\theta$ de menor tamanho que são capazes de atravessar as paredes do aparelho digestivo penetrando nas células e no sangue.

Essa redução das partículas é realizada por meio de enzimas ou fermentos digestivos que exigem para sua ação um ambiente satisfatório em relação ao $\mathrm{pH}$. Algumas agem melhor em meio fortemente ácido como, por exemplo, nos vertebrados que em geral é realizada no estômago, através de glândulas secretoras de ácido. Existe também uma outra etapa alcalina que em muitos animais é realizada no intestino.

A glicose então, sendo oxidada pelo oxigênio do ar, resulta em $673 \mathrm{kcal}$ por molécula grama de glicose consumida e, são essas calorias que constituem a energia necessária à atividade muscular dos animais.

Segundo a reação citada abaixo:

$$
\mathrm{C}_{6} \mathrm{H}_{12} \mathrm{O}_{6}+6 \mathrm{O}_{2} \longrightarrow 6 \mathrm{CO}_{2}+6 \mathrm{H}_{2} \mathrm{O}+673 \mathrm{kcal}
$$

Como todo processo de oxidação, o processo respiratório pode ser realizado pela simples retirada de átomos de hidrogênio da molécula orgânica sendo transferidos a outros compostos denominados de aceptores de hidrogênio. Neste caso quando o aceptor de hidrogênio for o oxigênio livre a respiração é dita aeróbia. Caso o aceptor seja qualquer outra substância, a respiração é dita anaeróbia. Neste último tipo de respiração, além do gás carbônico, outros produtos finais são formados como álcoois ou ácidos orgânicos e, pelo fato de não ocorrer oxidação total, a quantidade de energia liberada é menor em comparação com a respiração aeróbia (BRANCO 1967). 
Exemplo de respiração realizada por microorganismo, que ao fermentar a glicose, produz álcool:

$$
\mathrm{C}_{6} \mathrm{H}_{12} \mathrm{O}_{6} \longrightarrow 2 \mathrm{CO}_{2}+2 \mathrm{C}_{2} \mathrm{H}_{5} \mathrm{OH}
$$

Ao contrário da respiração, a fotossíntese, com o aproveitamento da energia luminosa se resume em transformar substâncias mais simples em compostos orgânicos, papel desempenhado por pigmentos verdes presentes nos vegetais, de estrutura semelhante à hemoglobina do sangue, formada por quatro anéis de pirrol ligados a um núcleo de magnésio, denominado clorofila presente em todos vegetais clorofilados, (BRANCO 1986).

A reação é dita fotoquímica, pois com o aproveitamento da luz, o gás carbônico absorvido do ar, é combinado com a água na proporção de $673 \mathrm{kcal}$ por molécula grama formando açúcar e como sub-produto, oxigênio.

Inicialmente a equação desse processo se resumia em:

$$
6 \mathrm{CO}_{2}+6 \mathrm{H}_{2} \mathrm{O} \underset{\text { clorofila }}{\longrightarrow} \mathrm{C}_{6} \mathrm{H}_{12} \mathrm{O}_{6}+6 \mathrm{O}_{2}
$$

Com o objetivo de seguir seu curso no interior do organismo ou na seqüência da reação, através de pesquisas com isótopos radioativos como elementos marcados foi possível verificar que o oxigênio final provém da água consumida e não do gás carbônico. Conclui-se assim, que o número de moléculas da água que entram na reação deve ser maior, a fim de fomecer as seis moléculas de oxigênio liberadas para atmosfera. 
Para representação do processo, segue a seguinte reação:

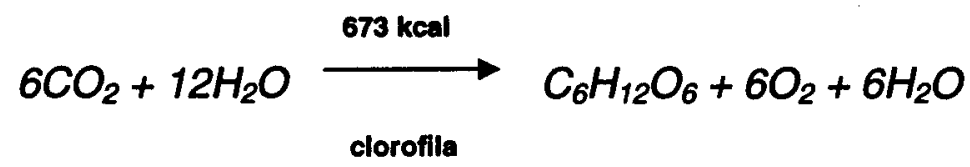

Os principais fatores que causam variação na velocidade dessa reação são: quantidade e qualidade de luz, teor de gás carbônico disponível, temperatura, etc.

\subsection{O papel das bactérias}

Em condições aeróbias, as bactérias são as principais responsáveis pela degradação da matéria orgânica. Através de enzimas catalisadoras liberadas pela própria célula, tais organismos decompõem as substâncias orgânicas mais complexas como: carboidratos, proteínas e gorduras em materiais solúveis que, ao serem absorvidos pela membrana celular convertem-se em: energia, novas células bacterianas e produtos finais (dióxido de carbono, nitratos e fosfatos). As bactérias mais freqüentes são as Pseudomonas $s p$, Flavobacterium $s p \Theta$ Achromobacter (CETESB 1989).

Em condições anaeróbias, a estabilização da matéria orgânica é realizada pelas bactérias acidogênicas e metanogênicas, resultando em: dióxido de carbono, metano, gás sulfídrico e amônia (KELLNER 1998).

\subsection{O papel das algas.}

Conforme BRANCO (1996), as algas são organismos uni ou pluricelulares, móveis ou fixos, dotados de clorofila, que produzem o oxigênio através de pigmentos fotossintéticos, utilizados pelas bactérias aeróbias no processo de estabilização da matéria orgânica e também 
para suprir a demanda da própria atividade respiratória das algas durante a noite.

GLOYNA (1971), ressalta que o oxigênio produzido pela fotossíntese das algas é suficiente para garantir durante o dia a respiração dos organismos aeróbios, embora a quantidade produzida dependa do tipo de alga, da forma como os nutrientes se apresentam no meio e do estágio de degradação da matéria orgânica.

Outro efeito importante proporcionado indiretamente pelas algas decorre do consumo de dióxido de carbono, sub-produto das bactérias saprófritas, elevando assim o $\mathrm{pH}$ do líquido para valores que variam entre 8 e 11. Com a elevação do pH acima desses valores, ocorrerá: redução das bactérias saprofíticas, prejudicando os processos de decomposição orgânica, precipitação dos fosfatos de cálcio, perda parcial da amônia para atmosfera e mortandande e/ou redução das bactérias entéricas (E.Coli) (CETESB 1989).

Existem muitas formas de algas nas lagoas, entretanto, por estarem associadas com a qualidade da lagoa, duas delas estão sempre presentes (CETESB 1989).

- algas verdes: conferem cor esverdeada a lagoa $\theta$ indicam boa condição de funcionamento, presentes em meio líquido balanceado em nutrientes e pH elevado

- algas azuis: predominantes em lagoas com pH próximo ao neutro ou tendendo ao alcalino, águas com temperaturas elevadas (acima de $30^{\circ} \mathrm{C}$ ), onde ocorra deficiência de nutrientes (principalmente nitrogênio). Por possuírem pseudo-vacúolos de gás em suas células, estas algas flutuam na superfície do líquido, dificultando a penetração de luz e exalam odores desagradáveis ao se decomporem.

Alguns gêneros de algas presentes nas lagoas de estabilização facultativas do Estado de São Paulo são apresentados no quadro 5.4. 
Quadro 5.4 - Gêneros de algas presentes nas lagoas de estabilização do Estado de São Paulo.

\begin{tabular}{|l|l|l|l|}
\hline \multicolumn{1}{|c|}{ Algas verdes } & Fitoflagelados & \multicolumn{1}{|c|}{ Algas azuis } & Diatomáceas \\
\hline Scenedesmus & Trachlelomonas & Oscillatoria & Cyclotella \\
\hline Ankistrodesmus & Euglena & Microcystis & \\
\hline Golenkinia & Phacus & Synechococcus & \\
\hline Oocystis & Chlamydomona & Synechocystis & \\
\hline Micractinium & Peranema & Merimospedia & \\
\hline Tetrastrum & Pandorina & & \\
\hline Closteriopsis & lepocinalis & & \\
\hline Chlorella & Hemidinium & & \\
\hline Crucigenia & Petalomonas & & \\
\hline Planktosphaeria & Peridinium & & \\
\hline Coelastrum & Gumnodinium & & \\
\hline Protococcus & Synura & & \\
\hline Actinastrum & Heteronema & & \\
\hline Dictyosphaerium & & & \\
\hline Coronastrum & & & \\
\hline Nephrochlamys & & & \\
\hline Chlorococcum & & & \\
\hline Cosmarium & & & \\
\hline Tetraspora & & & \\
\hline Sphaerocystis & & & \\
\hline Protococcus & & & \\
\hline
\end{tabular}

FONTE: CETESB (1989) 


\subsection{Lagoas anaeróbias}

As lagoas anaeróbias operam com ausência de oxigênio livre e sem aeração, é caracterizada por receber altas cargas orgânicas com um curto período de detenção e uma coloração escura quando ocorre processo de fermentação metânica, gerando como um dos produtos finais o gás metano. No entanto, algumas lagoas anaeróbias, na sua fase inicial de operação que recebem baixas concentrações de material orgânico apresentam uma coloração rosada (YANEZ 1993).

Segundo JORDÃO e PESSOA (1995), apesar do aspecto não ser agradável, a massa cinzenta formada denominada escuma tem como objetivo:

$>$ obstruir a entrada de luz solar, impedindo a formação de algas e, conseqüentemente a produção de oxigênio, garantindo assim a anaerobiose do meio;

$>$ evitar trocas gasosas com o meio;

$>$ controlar a saída de gases com odores fortes;

$>$ proteger a lagoa contra curtos-circuitos provocados pelos ventos.

Estudos recentes a respeito dessas lagoas, indicaram ainda que, as taxas de mortalidade bacteriana são inferiores quando comparadas com outros tipos de lagoas, demonstrando sua desvantagem quando o critério de qualidade para o efluente é a concentração bacteriana (SAQQAR \& PESCOD 1988 apud YANEZ 1993).

Ao se fazer uma analogia a uma estação de tratamento de esgoto convencional, a lagoa anaeróbia representa 0 decantador primário e 0 digestor anaeróbio. Os materiais sólidos sedimentados no fundo da lagoa são decompostos anaerobicamente $\Theta$ a eficiência na remoção da DBO está relacionada com a quantidade e natureza desse material sedimentável (GLOYNA 1971). 
SILVA \& MARA (1979) sugerem que, sejam mantidas temperaturas acima de $15^{\circ} \mathrm{C}$ e pH acima de 6 , criando assim, condições favoráveis para fermentação metânica, sendo alcançadas eficiências máximas com temperaturas em tomo de 30 a $35{ }^{\circ} \mathrm{C}$. Em baixas temperaturas de inverno, as velocidades das taxas de degradação são inferiores quando comparadas com temperaturas de verão, resultando em maior acúmulo de lodo nesses períodos.

MENDONÇA (1990) menciona que, a principal desvantagem do tratamento anaeróbio é a possibilidade de geração de odores desagradáveis produzidos pela liberação do gás sulfídrico $\left(\mathrm{H}_{2} \mathrm{~S}\right)$, em contrapartida, as lagoas anaeróbias tem a finalidade de oxidar compostos orgânicos complexos em áreas bem reduzidas.

Segundo PESCOD (1995) apud KELLNER (1998), os problemas de exalação de maus odores, produzidos principalmente pela liberação do sulfeto de hidrogênio na atmosfera, podem advir do desequilíbrio entre bactérias acidogênicas e metanogênicas. Quando o afluente apresenta concentrações de sulfato superior a $100 \mathrm{mg} / \mathrm{l}$ e $\mathrm{opH}$ situa-se abaixo de 7,5 , problemas com odores desagradáveis são esperados.

A fim de se evitar problemas com maus odores, MARA \& PEARSON (1995) apud KELLNER (1998), consideram o valor de $500 \mathrm{mg} \mathrm{SO}_{4}{ }^{-2} / \mathrm{m}^{3}$.dia como a taxa máxima volumétrica de aplicação de sulfato em lagoas anaeróbias.

A digestão anaeróbia é um processo fermentativo composto por várias reações seqüenciais, cada um com sua população bacteriana específica. Na figura 5.2, proposta por KASPAR \& WUHRMANN (1987) apud VAN HAANDEL (1999), é apresentada uma representação esquemática dos vários processos que ocorrem na digestão anaeróbia (Hidrólise, Acidogênese, Acetogênese e Metanogênese). 


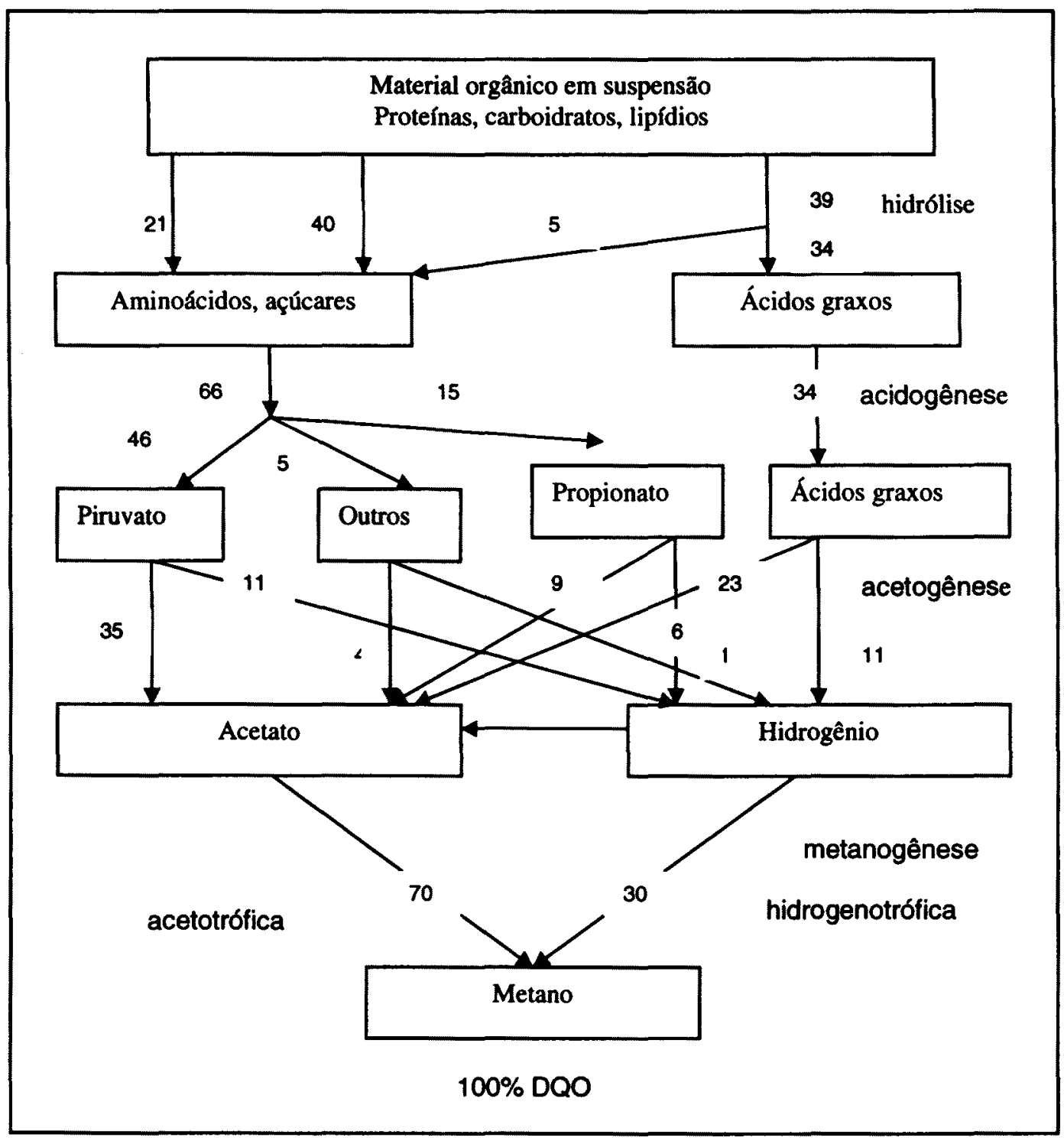

Figura 5.2 Processos na digestão anaeróbia (os números referem-se a porcentagens, expressas como DQO).

FONTE: VAN HAANDEL (1999)

No processo de hidrólise, o material orgânico particulado é convertido em compostos dissolvidos de menor peso molecular, através de exo-enzimas excretadas pelas bactérias fermentativas. Os compostos dissolvidos na hidrólise são absorvidos nas células das bactérias fermentativas $\theta$, após a acidogênese, excretadas como substâncias orgânicas simples como ácidos graxos voláteis de cadeia curta, álcoois e 
compostos minerais $\left(\mathrm{CO}_{2}, \mathrm{H}_{2}, \mathrm{NH}_{3}, \mathrm{H}_{2} \mathrm{~S}\right)$. A maior parte das bactérias que realizam a fermentação acidogênica são anaeróbias, entretanto, algumas espécies facultativas auxiliem no processo consumindo o oxigênio dissolvido eventualmente presente que, sem a devida remoção, poderia se tomar tóxico as bactérias metanogênicas. (VAN HAANDEL 1999).

No processo de acetogênese ocorre a conversão dos produtos da acidogênese em compostos que formam substratos para produção de metano: acetato, hidrogênio e dióxido de carbono. Cerca de $70 \%$ da DQO digerida é convertida em ácido acético, enquanto que o restante da DQO concentra-se no hidrogênio. No último processo denominado metanogênese, o gás metano é produzido por bactérias acetotróficas,a partir da redução do ácido acético, ou pelas bactérias hidrogenotróficas, a partir da redução do dióxido de carbono, segundo reaçōes abaixo (VAN HAANDEL 1999).

Metanogênese acetotrófica ou acetoclástica<smiles>CCO[Po+][CH]CC=O</smiles>

Metanogênese hidrogenotrófica

$$
4 \mathrm{H}_{2}+\mathrm{HCO}_{3}^{-}+\mathrm{H}^{+} \longrightarrow \mathrm{CH}_{4}+2 \mathrm{H}_{2} \mathrm{O}
$$




\subsection{Lagoas facultativas}

YANEZ (1993), comenta em suas pesquisas que, indiscutivelmente as lagoas facultativas são as mais empregadas em todo mundo. Apesar da grande quantidade de estudos a respeito desse tipo de tratamento, existe uma série de dúvidas sobre inter-relações de alguns processos físicos (modelos hidráulicos de projeto e biomassa) com outros processos bioquímicos (cinéticas de reação, etc).

As lagoas facultativas são classificadas como: primárias ou secundárias, pois podem receber esgotos brutos ou decantados, efluentes de uma lagoa anaeróbia ou de um reator anaeróbio de fluxo ascendente (MENDONÇA 2000).

No Nordeste do Brasil, várias pesquisas realizadas vêm demonstrando o elevado grau de tratamento das lagoas, produzindo efluentes com $\mathrm{DBO}_{5}$ inferior a $30 \mathrm{mg} / \mathrm{l}$ e $1000 \mathrm{NMP} / 100 \mathrm{ml}$ de coliformes termotolerantes (SILVA 1982).

Conforme VON SPERLING (1995), as lagoas facultativas são caracterizadas por possuírem três camadas. A camada superior, conhecida como zona aeróbia, onde ocorre à estabilização da matéria orgânica através das bactérias aeróbias No fundo da lagoa predomina a zona anaeróbia, onde não há passagem de luz e ocorrem os processos de fermentação metanogênica do material sedimentado, dando origem ao lodo. E por último, existe ainda uma camada intermediária dita facultativa, pois à noite além de cessar a incidência de luz, as algas também passam a consumir o oxigênio produzido durante o dia. Essa camada ora funciona como aeróbia, ora como anaeróbia, como mostra a figura 5.3. 


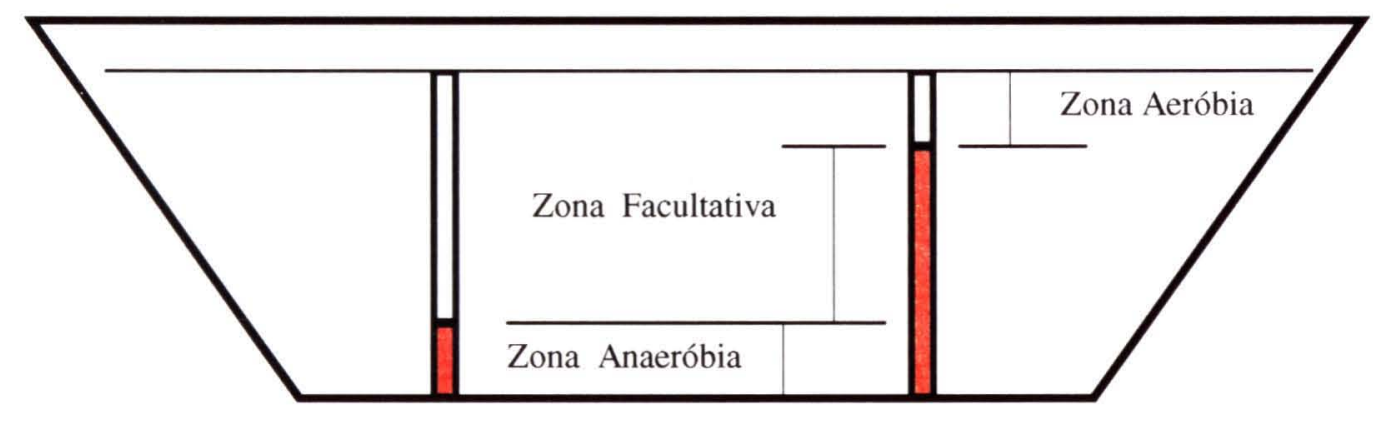

DIA NOITE

Figura 5.3 - Variação das Zonas Aeróbias e Anaeróbias.

FONTE: VON SPERLING (1995)

A quantidade de oxigênio necessária na camada aeróbia depende fundamentalmente da atividade fotossintética das algas que, diretamente, depende das condições climáticas predominantes e da presença de nutrientes como fósforo, nitrogênio entre outros, proporcionando um ambiente adequado para o seu crescimento. KONIG (1990), cita que além das algas, outra forma de suprimento de oxigênio provém da reaeração superficial da interface ar/água provocada pelos ventos.

Sendo assim, o oxigênio produzido é utilizado pelas bactérias aeróbias no processo de decomposição da matéria orgânica, convertendo esse material em dióxido de carbono, fosfatos, amônia, etc. $\mathrm{O} \mathrm{CO}_{2}$ desprendido e os nutrientes são sintetizados pelas algas para seu próprio desenvolvimento, resultando em uma associação de mútuo benefício, como mostra a figura 5.4 (VICTORETTI 1968).

Existe também uma competição entre bactérias e protozoários processando simultaneamente a matéria orgânica solúvel, porém, as bactérias são menores e metabolizam o substrato de uma forma mais rápida que os protozoários que se apresentam em tamanhos maiores e 
com taxas metabólicas menores. Pela facilidade com que podem ser observados nos microscópios, os protozoários são considerados importantes indicadores de qualidade do efluente (MC KINNEY 1962 apud KELLNER 1998).

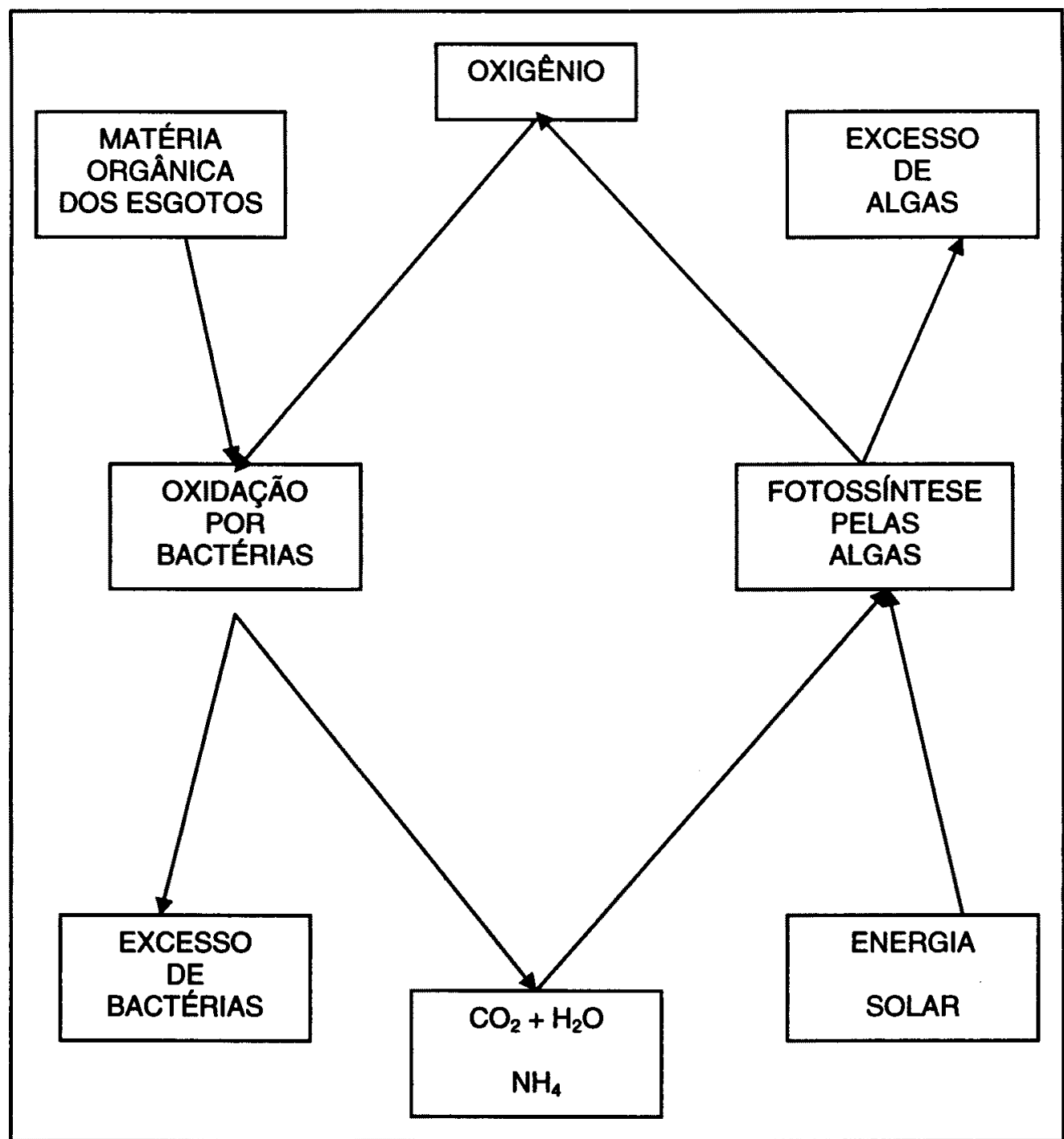

FIGURA 5.4 Simbiose entre algas e bactérias.

FONTE: VICTORETTI (1968)

O estudo comparativo dos gêneros de algas presentes em lagoas de estabilização de várias localidades deve levar em consideração: as características do esgoto, mudanças na intensidade luminosa $e$ temperatura (variáveis dependentes da latitude) (KONIG 1990). 
As Equações 5.1 e 5.2, encontradas por MARA \& PEARSON (1986), representam as correlaçōes entre a concentração de clorofila a presente no efluente $\theta$ a taxa de aplicação superficial.

CLO $=1072-2,556 * \lambda_{s} ; \quad 100<\lambda_{s}<350 \mathrm{~kg} / \mathrm{DBO} / \mathrm{ha}$.dia (5.1)

CLO $=1248-2,020 * \lambda_{s} ; \quad 350<\lambda_{s}<600 \mathrm{~kg} / \mathrm{DBO} / \mathrm{ha}$.dia (5.2)

Onde:

CLO $=$ concentração de clorofila $a(\mu g / L)$

$\lambda_{s}=$ taxa de aplicação superficial (KgDBO/ha.dia)

Quando a profundidade de tubulação de descarga encontra-se próximo á superfície, segundo MARA et al (1983), é possível encontrar uma grande variação na concentração de algas. Essa variação ocorre devido ao acúmulo de algas nas camadas superiores da lagoa (10 a $15 \mathrm{~cm}$ ), representando até $80 \%$ dos sólidos suspensos, $60-75 \%$ da DQO e mais de $65 \%$ do valor da $\mathrm{DBO}_{5}$ (PEARSON \& SILVA 1988).

Um dos procedimentos adotados por vários projetistas para minimizar o problema consiste em assentar a tubulação aproximadamente a $40 \mathrm{~cm}$ da superfície (KELLNER 1998).

PEARSON et al (1987) ainda sugerem que, com a possível concentração de sulfeto, a tubulação de entrada do efluente da lagoa anaeróbia na lagoa facultativa seja disposta no fundo da lagoa, evitando assim, interferências no desenvolvimento das algas localizadas principalmente na superfície. 


\subsubsection{Modelos matemáticos utilizados no} dimensionamento de lagoas de estabilização

Desde que foram construídas as primeiras lagoas de estabilização, os pesquisadores vêm buscando encontrar relações ou modelos matemáticos para seu dimensionamento KELLNER (1998).

Com isso, muitos modelos matemáticos são empregados no dimensionamento de lagoas de estabilização e para cada cálculo são obtidos volumes diferentes (METCALF \& EDDY 2003).

YANEZ (1993) comenta que, em função do grande número de variáveis e modelos existentes para se dimensionar a estação, o engenheiro projetista encontra uma certa liberdade para escolher qual o melhor critério a ser empregado.

Os modelos utilizados podem ser classificados em: empíricos e racionais. Os modelos empíricos são simples e não necessitam de parâmetros difíceis de serem encontrados. Baseiam-se a partir da observação das características físicas e operacionais de lagoas que funcionam satisfatoriamente e apresentam bons índices de eficiência. Entretanto, sua aplicação é limitada $\theta$ alguns desses parâmetros obtidos podem variar dentro de faixas relativamente amplas (KELLNER 1998).

Os modelos racionais seguem uma teoria racional sobre o funcionamento da estação. Para se determinar parâmetros que interferem no processo são empregadas lagoas piloto e ensaios laboratoriais. Tais parâmetros estão relacionados com resultados de operação, de onde surgem equações que descrevem o fenômeno e permitem sua reprodução em condições controladas. Um desses fatores que interferem no desenvolvimento dos modelos racionais é a temperatura da massa líquida (MENDONÇA 2000). 


\subsubsection{Modelos empíricos}

\subsection{Lagoas anaeróbias}

\subsection{Método da taxa de aplicação volumétrica}

Para o dimensionamento das lagoas anaeróbias são utilizadas as taxas de aplicação volumétrica, apresentadas no quadro 5.5. Portanto, o volume da lagoa pode ser calculado através da equação 5.3.

$$
V=\frac{\mathrm{DBO} 5^{*} \mathrm{Qméd}}{\lambda_{r}}
$$

Onde:

$V=\quad$ volume da lagoa $(\mathrm{m} 3)$

$\mathrm{DBO}_{5}=\mathrm{DBO}$ de 5 dias do afluente $(\mathrm{mg} / \mathrm{l})$

$Q$ méd. = vazão média afluente $\left(\mathrm{m}^{3} / \mathrm{d}\right)$

$\lambda_{v}=$ taxa de aplicação volumétrica $\left(\mathrm{g} \mathrm{DBO}_{5} / \mathrm{m}^{3 *} \mathrm{~d}\right)$

Quadro 5.5 Taxas de aplicação volumétricas para lagoas anaeróbias.

\begin{tabular}{c|c|c}
\hline $\begin{array}{c}\text { Taxa de aplicação } \\
\text { volumétrica } \lambda_{v}\left(\mathrm{~g} \mathrm{DBO} \mathrm{D}_{5} / \mathrm{m}^{3 *} \mathrm{~d}\right)\end{array}$ & $\begin{array}{c}\text { Profundidade } \\
(\mathrm{m})\end{array}$ & Fonte \\
\hline $50-150$ & $3,0-4,5$ & $\begin{array}{c}\text { JORDÃO e PESSOA } \\
(1982)\end{array}$ \\
\hline $190-240$ & $3,0-5,0$ & UEHARA E VIDAL (1989) \\
\hline $200-250$ & $2,0-4,0$ & MARA \& SILVA (1979) \\
\hline $100-300$ & $4,0-5,0$ & VON SPERLING (1996) \\
\hline
\end{tabular}

FONTE: adaptado KELLNER (1998) 
Para manter condições anaeróbias na lagoa, MARA (1976), sugere a taxa de aplicação volumétrica $\lambda_{v}>100 \mathrm{~g} \mathrm{DBO} / \mathrm{m}^{3 *} \mathrm{~d}$, entretanto, a autora ressalta que, para $\lambda_{v}>400 \mathrm{~g} \mathrm{DBO} / \mathrm{m}^{3 *} \mathrm{~d}$ podem ocorrer problemas de odor. Já JORDÃO e PESSOA (1995) citam que, no Brasil existem lagoas operando bem com taxas de aplicação volumétrica em torno de $50 \mathrm{~g} \mathrm{DBO}_{5} / \mathrm{m}^{3 *} \mathrm{~d}$.

\subsection{Método do tempo de detenção hidráulico}

Além do método de dimensionamento de lagoas anaeróbias citado acima, outro método bastante utilizado pelos projetistas baseia-se no tempo de detenção hidráulico, conforme equação 5.4 (VON SPERLING, 1996).

$$
V=T^{*} \text { Qméd }
$$

Onde:

$V=\quad$ volume da lagoa $\left(\mathrm{m}^{3}\right)$

$\mathrm{T}=\quad$ tempo de detenção hidráulico (dias)

$Q$ méd.= vazão média afluente $\left(\mathrm{m}^{3} / \mathrm{d}\right)$

A eficiência desse processo está intimamente relacionada ao tempo de detenção $\theta$ à temperatura do líquido, apresentados no quadro 5.6. Através de pesquisas realizadas em diversos países como: Zâmbia, África, Austrália, Israel e Índia, ARCEIVALA (1981), propôs tempos de detenção inferior a 5 dias. 
Quadro 5.6 Resultados obtidos com lagoas anaeróbias que tratam despejos domésticos com períodos de detenção inferior a cinco dias.

\begin{tabular}{|c|c|c|}
\hline $\begin{array}{c}\text { Temperatura da lagoa } \\
\text { anaeróbia }\left({ }^{\circ} \mathrm{C}\right)\end{array}$ & $\begin{array}{c}\text { Tempo de } \\
\text { detenção } \\
\text { (dias) }\end{array}$ & $\begin{array}{c}\text { Provável eficiência de } \\
\text { remoção de DBO } \\
(\%)\end{array}$ \\
\hline $10-15$ & $4,0-5,0$ & $30-40$ \\
\hline $15-20$ & $2,0-3,0$ & $40-50$ \\
\hline $20-25$ & $1,0-2,0$ & $40-60$ \\
\hline $25-30$ & $1,0-2,0$ & $60-70$ \\
\hline
\end{tabular}

FONTE: ARCEIVALA (1981)

Em seus trabalhos, KAMIYAMA (1989), apresenta porcentagens de redução de DBO a partir de várias temperaturas do líquido para um mesmo tempo de detenção hidráulico (quadro 5.7).

Quadro 5.7 Porcentagem de redução de $\mathrm{DBO}_{5}$, em função da temperatura da água e do tempo de detenção hidráulico.

\begin{tabular}{c|c|c|c|c}
\hline \multirow{2}{*}{$\begin{array}{c}\text { Tempo } \\
\text { (dias) }\end{array}$} & \multicolumn{4}{|c}{ Porcentagem de redução de $\mathrm{DBO}_{5}(\%)$} \\
\cline { 2 - 5 } & $10^{\circ} \mathrm{C}$ & $14^{\circ} \mathrm{C}$ & $15^{\circ} \mathrm{C}$ & $18^{\circ} \mathrm{C}$ \\
\hline 1 & 23 & 35 & 47 & 33 \\
\hline 2 & 40 & 61 & 56 & 53 \\
\hline 4 & 46 & 70 & 67 & 56 \\
\hline 9 & 57 & 75 & 75 & 81 \\
\hline 16 & 72 & 89 & 90 & 87 \\
\hline 32 & 90 & 90 & 95 & \\
\hline 64 & 94 & & 94 & \\
\hline
\end{tabular}

FONTE: KAMIYAMA (1989)

VON SPERLING (1996) ressalta que, com tempos de detenção inferiores a 3 dias, poderá ocorrer uma taxa de saída das bactérias metanogênicas com o efluente da lagoa superior à sua taxa de 
reprodução, conseqüentemente, haverá redução da eficiência da lagoa causando desequilíbrio entre as fases acidogênicas e metanogênicas que resultarão em acúmulo de ácidos no meio e geração de odores desagradáveis pelo fato de haver poucas bactérias para dar continuidade à conversão dos ácidos.

Ainda segundo o autor, tempos de detenção superiores a 6 dias não são recomendados pois podem levar a lagoa a condições aeróbias, prejudicando o desenvolvimento das bactérias metanogênicas (sensíveis na presença de oxigênio).

Os tempos de detenção propostos pela Norma Brasileira (1991) citados por (VON SPERLING 1996) são apresentados no quadro 5.8.

Quadro 5.8 Tempos de detenção propostos segundo NBR (1991).

\begin{tabular}{|c|c|c|}
\hline \multirow{2}{*}{$\begin{array}{c}\text { Temperatura média da } \\
\text { lagoa no mês mais frio }\left({ }^{\circ} \mathrm{C}\right)\end{array}$} & \multicolumn{2}{|c|}{ Tempo de detenção (d) } \\
\cline { 2 - 3 } & Início de plano & Final de plano \\
\hline$\leq 20$ & $\geq 4$ & $\leq 6$ \\
\hline$>20$ & $\geq 3$ & $\leq 5$ \\
\hline
\end{tabular}

FONTE: VON SPERLING (1996). 


\subsection{Lagoas facultativas}

\subsection{Método da taxa de aplicação superficial}

No dimensionamento de lagoas facultativas, os principais parâmetros de interesse no projeto são de natureza física e de carga orgânica medidos em termos de kg. DBO/ha.d (JORDÃO e PESSOA 1995).

Segundo VON SPERLING (1996), o modelo matemático que utiliza a taxa de aplicação superficial no dimensionamento do sistema, leva em consideração a área da lagoa exposta à luz solar para que, através do processo fotossintético realizado pelas algas ocorra produção de oxigênio.

Neste caso, a área necessária é calculada pela equação 5.5 .

$$
V=\frac{\mathrm{DBO}_{\tau}{ }^{*} \mathrm{Qméd}}{1000 * \lambda s}
$$

Onde:

$A=\quad$ área da lagoa $\left(\mathrm{m}^{2}\right)$

$\mathrm{DBO}_{\mathrm{T}}=\mathrm{DBO}$ total do afluente $(\mathrm{mg} / \mathrm{l})$

Q méd.= vazão média afluente $\left(\mathrm{m}^{3} / \mathrm{d}\right)$

$\lambda s=$ taxa de aplicação superficial $\left(\mathrm{kg} \mathrm{DBO}_{5} / \mathrm{ha}^{*} \mathrm{~d}\right)$

$\mathrm{Na}$ escolha da taxa a ser aplicada, deve-se levar em consideração a temperatura local, latitude, exposição solar, altitude e outros, uma vez que, locais com insolação e climas favoráveis como no Nordeste do Brasil, permitem a adoção de taxas mais elevadas ( $300 \mathrm{kgDBO}_{5} / \mathrm{ha}^{*} \mathrm{~d}$ ), resultando em menores áreas superficiais. A seguir, no quadro 5.9 são apresentadas algumas taxas de aplicação superficial adotadas no Brasil (VON SPERLING 1996). 
Quadro 5.9 Taxas de aplicação superficial adotadas no Brasil.

Regiões com inverno quente e elevada insolação $\lambda_{s}=240$ a $350 \mathrm{kgDBO} / \mathrm{ha}{ }^{*} \mathrm{~d}$

Regiões com inverno e insolação moderados $\lambda_{s}=120$ a $240 \mathrm{kgDBO} / \mathrm{ha}{ }^{*} \mathrm{~d}$

Regiões com inverno frio e baixa insolação $\lambda_{s}=100$ a $180 \mathrm{kgDBO} / \mathrm{ha}{ }^{*} \mathrm{~d}$

FONTE: VON SPERLING (1996)

GLOYNA (1971), sugere taxas de aplicação superficial levando-se em consideração população e tempos de detenção, conforme quadro 5.2. Entretanto, KELLNER (1998) adverte que, em condições diferentes daquelas apresentadas no quadro 5.10, poderão ocasionar lagoas com grandes áreas. Ainda segundo o autor, o quadro 5.11 apresenta as profundidades a serem estimadas no dimensionamento.

Quadro 5.10 Taxas de aplicação superficial para lagoas facultativas, em função das condições ambientais do local da implantação.

\begin{tabular}{|c|c|c|c|}
\hline $\begin{array}{c}\lambda_{s}^{*} \\
\text { kgDBO/ha*d }\end{array}$ & $\begin{array}{c}\text { População } \\
\text { (hab) }\end{array}$ & $\begin{array}{c}\text { T } \\
\text { (dias) }\end{array}$ & Condições locais \\
\hline$<10$ & $<200$ & $>200$ & $\begin{array}{l}\text { Regiōes frias com } \\
\text { coberturas sazonais } \\
\text { de gelo, baixa } \\
\text { temperatura de água }\end{array}$ \\
\hline $10-50$ & $200-1000$ & $200-100$ & $\begin{array}{c}\text { Clima frio com } \\
\text { cobertura sazonal de } \\
\text { gelo, temperatura de } \\
\text { verão temperada e } \\
\text { presente por pequnos } \\
\text { periodos }\end{array}$ \\
\hline $50-150$ & $1000-3000$ & $100-33$ & $\begin{array}{c}\text { Regiōes temperadas, } \\
\text { semitropicais, } \\
\text { cobertura de gelo } \\
\text { ocasional }\end{array}$ \\
\hline $150-300$ & $3000-7000$ & $33-17$ & $\begin{array}{c}\text { Regiōes tropicais, sol } \\
\text { e temperatura } \\
\text { uniformemente } \\
\text { distribuídos. }\end{array}$ \\
\hline
\end{tabular}

FONTE: GLOYNA (1971) 
Quadro 5.11 Profundidades recomendadas para lagoas facultativas em função das características do esgoto afluente ou das condições climáticas locais.

\begin{tabular}{|c|l|l|}
\hline $\begin{array}{c}\mathbf{h} \\
(\mathbf{m})\end{array}$ & Tipo de esgoto a tratar & \multicolumn{1}{c|}{ Condições locais } \\
\hline 1,0 & Esgoto pré-decantado & $\begin{array}{l}\text { Temperatura uniforme e } \\
\text { quente }\end{array}$ \\
\hline 1,0 a-1,5 & Esgoto bruto & $\begin{array}{l}\text { Temperatura uniforme e } \\
\text { quente }\end{array}$ \\
\hline 1,5 a 2,0 & $\begin{array}{l}\text { Esgoto contendo sólidos } \\
\text { sedimentáveis }\end{array}$ & $\begin{array}{l}\text { Variações na temperatura, } \\
\text { moderadas e sazonais }\end{array}$ \\
\hline 2,0 a 3,0 & $\begin{array}{l}\text { Grande quantidade de } \\
\text { areia ou sólidos } \\
\text { sedimentáveis }\end{array}$ & $\begin{array}{l}\text { Sensíveis variações sazonais } \\
\text { de temperatura }\end{array}$ \\
\hline
\end{tabular}

FONTE: KELLNER (1998)

\subsubsection{Modelos racionais}

Já citado anteriormente, um dos fatores interferentes nos modelos racionais é a temperatura da massa líquida. No entanto, como na fase inicial de projeto, a maioria dos dados publicados refere-se à temperatura do ar, alguns autores correlacionaram a temperatura do ar com a temperatura média do líquido na lagoa, conforme quadro 5.12 (KELLNER 1998).

Quadro 5.12 Correlações entre temperatura média das lagoas facultativas e a temperatura do ar.

\begin{tabular}{c|l|c}
\hline Correlação & \multicolumn{1}{|c|}{ Tipo de esgoto a tratar } & $\begin{array}{c}\text { Condiçōes } \\
\text { locais }\end{array}$ \\
\hline$T=10,433+0,688^{*} T_{a r}$ & Lagoa de San Juan, Peru & Yanez (1988) \\
\hline$T=2,688+0,945^{\star} T_{a r}$ & Lagoas de Aman,Jordânia & Yanez (1988) \\
\hline$T=10,966+0,611^{*} T_{a r}$ & $\begin{array}{l}\text { Lagoa Experimental de Campina } \\
\text { Grande(Brasil) }\end{array}$ & Yanez(1988) \\
\hline
\end{tabular}

FONTE: KELLNER (1998) 


\subsection{Modelo proposto por MC GARRY \& PESCOD}

MC GARRY e PESCOD (1970) apud KELLNER (1998), juntaram dados de 143 lagoas facultativas primárias que operavam em condiçōes distintas e em média com remoção de $72,5 \%$ de matéria orgânica. A partir desses dados, chegaram a equações que caracterizam a máxima carga orgânica aplicável em lagoas facultativas e a correlação entre cargas orgânicas aplicadas e removidas, conforme equações 5.6 e 5.7 respectivamente:

$$
\begin{aligned}
& \lambda_{s}=60,272 *(1,0993)^{\mathrm{Tar}} \\
& \lambda_{r}=10,35+0,725^{\star} \lambda_{s}
\end{aligned}
$$

válida para a seguinte condição $50 \leq \lambda_{s} \leq 500$

Onde:

$$
\begin{aligned}
& \lambda_{s}=\text { taxa de aplicação superficial }\left(\mathrm{kgDBO} / \mathrm{ha}^{*} \mathrm{~d}\right) \\
& \mathrm{T}_{\text {ar }}=\text { temperatura do } \operatorname{ar}\left({ }^{\circ} \mathrm{C}\right) \\
& \lambda_{r} \quad=\text { carga orgânica removida }\left(\mathrm{kgDBO} / \mathrm{ha}^{*} \mathrm{~d}\right)
\end{aligned}
$$

MARA (1976) e SILVA e MARA (1979) apud VON SPERLING (1996), ao analisarem os resultados das 143 lagoas constataram que, 11 estações não apresentavam eficiência adequada $\theta$ outras operavam com taxa de aplicação superficial superior a $600 \mathrm{kgDBO} / \mathrm{ha}$ *d. Assim, MARA (1976), propôs uma alternativa para as condições citadas acima: restringiu a temperatura entre 15 e $30^{\circ} \mathrm{C}$ e adaptou $\lambda_{s}$ segundo a equação 5.8 .

$$
\lambda_{s}=20 * T_{\text {ar }}-120
$$




\subsection{Modelo proposto por KAWAI, YANO \& SCHENEIDERMAN}

KAWAl et al (1981), efetuaram o levantamento de parâmetros de sete lagoas em operação pertencentes aos municípios de Guararapes, Nhandeara, Itapira, Pindamonhangaba, Pradópolis, Valparaíso e Mairiporã, e duas experimentais nos municípios de Maringá e Tatuí, onde puderam estabelecer critérios de projeto condizentes às condições brasileiras, mais especificamente para o estado de São Paulo.

Com exceção das lagoas de Valparaíso, Guararapes e Nhandeara, formadas por lagoas facultativas, as demais empregavam sistema australiano.

As amostras foram analisadas em termos de $\mathrm{DBO}_{5}$ (não filtrada) e, os autores, ao correlacionarem as cargas orgânicas aplicadas às cargas orgânicas removidas, chegaram as seguintes equações:

Para lagoas anaeróbias

$$
\lambda_{r}=-14,4555+0,6867^{\star} \lambda_{s}
$$

válida para as seguintes condições:

$$
\begin{aligned}
& 530 \leq \lambda_{s} \leq 2300 \mathrm{kgDBO} / \mathrm{ha}^{*} \mathrm{~d} \\
& 18 \leq \mathrm{T} \leq 25^{\circ} \mathrm{C} \\
& 4,3 \leq \theta \leq 10 \text { dias }
\end{aligned}
$$

Para lagoas facultativas primárias

$$
\lambda_{r}=22,43+0,8332^{*} \lambda_{s}
$$

válida para as seguintes condições:

$90 \leq \lambda_{s} \leq 210 \mathrm{kgDBO} / \mathrm{ha}^{*} \mathrm{~d}$

$19,5 \leq T \leq 25^{\circ} \mathrm{C}$ 
Para lagoas facultativas secundárias

$$
\lambda_{r}=-5,4188+0,7702^{*} \lambda_{s}
$$

válida para as seguintes condiçōes:

$$
\begin{aligned}
& 50 \leq \lambda_{s} \leq 170 \mathrm{kgDBO} / \mathrm{ha}^{*} \mathrm{~d} \\
& 19,5 \leq \mathrm{T} \leq 25^{\circ} \mathrm{C}
\end{aligned}
$$

Onde:

$$
\begin{array}{ll}
\lambda_{s} & =\text { taxa de aplicação superficial }\left(\mathrm{kgDBO} / \mathrm{ha}^{*} \mathrm{~d}\right) \\
\mathrm{T}_{\mathrm{ar}} & =\text { temperatura do } \operatorname{ar}\left({ }^{\circ} \mathrm{C}\right) \\
\lambda_{r} & =\text { carga orgânica removida (kgDBO/ha*d) } \\
\theta & =\text { tempo de detenção hidráulico (dias) }
\end{array}
$$

Para as lagoas facultativas primárias localizadas nas regiões Norte e Sul do Brasil, os pesquisadores sugerem taxas de aplicação superficial máximas de $400 \mathrm{kgDBO} / \mathrm{ha}^{*} \mathrm{~d}$ e $250 \mathrm{kgDBO} / \mathrm{ha}^{*} \mathrm{~d}$ respectivamente. Para as lagoas facultativas secundárias, a máxima carga orgânica aplicável deve situar-se em torno de $150 \mathrm{kgDBO} / \mathrm{ha}{ }^{*} \mathrm{~d}$.

\subsection{Modelo proposto por YANEZ}

Nos trabalhos realizados em sistemas de lagoas de San Juan, Lima (Peru), formado por 8 lagoas (4 primárias e 4 secundárias), YANEZ (1993), avaliou a correlação da taxa de aplicação superficial e a concentração de nitrogênio amoniacal presente tanto no afluente quanto o efluente, conforme equação 5.11 .

$\mathrm{Na}$ figura 5.5, onde são apresentadas as frações de nitrogênio em função da taxa de aplicação superficial, o autor menciona que, o ponto onde as concentrações de amônia $\left(\mathrm{NH}_{3}\right)$ do afluente e efluente se 
igualam $\left(\lambda S=357,4 \mathrm{kgDBO} / \mathrm{ha}^{*} \mathrm{~d}\right)$, corresponde ao limite de carga entre lagoas facultativas e anaeróbias. A partir desse valor predominam processos anaeróbicos.

$$
Y=\quad \frac{\mathrm{CSa}}{\left(57,88+0,84^{\star} \mathrm{CSa}\right)}
$$

Onde:

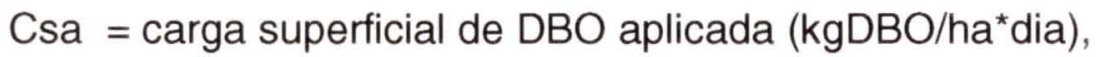
calculada como DBO total do afluente

$\mathrm{Y}$ = fração de amônia descartada da lagoa

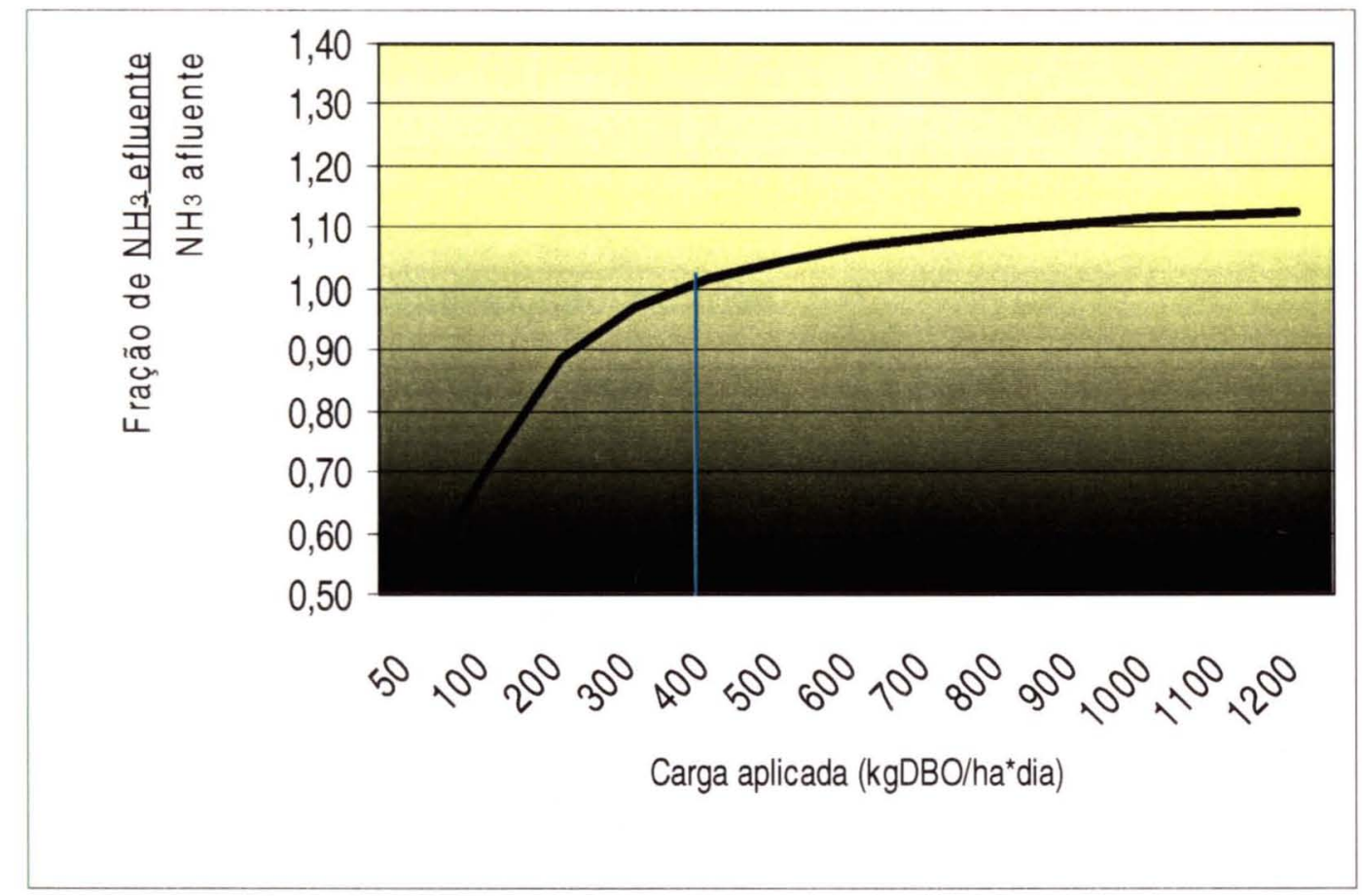

Figura 5.5 Correlação entre fração de nitrogênio amoniacal e taxa de aplicação superficial.

FONTE: YANEZ (1993)

Ao adotar 0 valor do coeficiente de Arrhenius proposto por GLOYNA (1971), $\beta=1,085$ e, a fim de se estimar a máxima carga 
orgânica a ser aplicada para manter condições aeróbias na lagoa, YANEZ (1993), sugere a seguinte equação (5.12).

$$
\lambda_{s}=357,4^{*}(1,085)^{T-20}
$$

Onde:

$\lambda_{s} \quad=$ taxa de aplicação superficial $\left(\mathrm{kgDBO} / \mathrm{ha}^{*} \mathrm{~d}\right)$

$\mathrm{T}_{\mathrm{ar}}=$ temperatura média do líquido na lagoa $\left({ }^{\circ} \mathrm{C}\right)$

Foi ainda observada pelo autor a relação entre a carga orgânica aplicada e a cargas orgânica removida, representadas pelas equações 5.13 e 5.14 respectivamente.

Lagoas facultativas primárias

$$
\lambda_{r}=7,67+0,8063^{*} \lambda_{s}
$$

Lagoas facultativas secundárias

$$
\lambda_{r}=-0,80+0,765^{\star} \lambda_{s}
$$

Onde:

$\lambda_{s}=$ taxa de aplicação superficial $\left(\mathrm{kgDBO} / \mathrm{ha}^{*} \mathrm{~d}\right)$

$\lambda_{r} \quad$ = carga orgânica removida $\left(\mathrm{kgDBO} / \mathrm{ha}^{*} \mathrm{~d}\right)$

\subsection{Modelo proposto por CUBILLOS}

Ao se estudar as lagoas do Instituto Colombiano agropecuário (ICA) e do Centro Internacional de Agricultura (CIAT), CUBILLOS (1986) apud KELLNER (1998), ao comparar os dados de $\mathrm{DBO}_{5}$ e coliformes, propôs alterações na equação (5.15) utilizada por HERMANN \& GLOYNA (1958). 


$$
V=C * Q_{a}{ }^{*} L_{a}{ }^{*} \beta^{(35-T) *} f
$$

Onde:

$V=$ volume da lagoa $(\mathrm{m} 3)$

$C=$ relação entre tempo de reação ótimo de 7 dias proposto por GLOYNA (1971) e a $\mathrm{DBO}_{5}$ padrão $200 \mathrm{mg} / \mathrm{l}$ estabelecido na pesquisa

$Q_{a}=$ vazão afluente $\left(\mathrm{m}^{3} / \mathrm{dia}\right)$

$L_{a}=D B O_{5}$ solúvel do afluente $\left(\mathrm{m}^{3} /\right.$ dia $)$

$\beta=$ coeficiente de Arrhenius $(1,085)$

$\mathrm{T}=$ temperatura média da lagoa no mês mais frio do ano $\left({ }^{\circ} \mathrm{C}\right)$

$f=$ fator de toxicidade das algas $(1,0)$

Para dimensionamento das lagoas facultativas primárias, considerando eficiência entre $60 \%$ e $90 \%$, CUBILLOS (1986) adotou a seguinte equação (5.16).

$$
V=2,8{ }^{*} Q_{a}{ }^{*} L_{a}{ }^{*} \beta^{(35-T)}
$$

Após simplificações a equação da taxa de aplicação superficial pode ser escrita dessa forma:

$$
\lambda_{s}=714,286 * h^{*}(1,085)^{T-20}
$$

$\mathrm{h}=$ profundidade $(\mathrm{m})$

A partir da equação 5.17 e verificando a eficiência de redução da $\mathrm{DBO}_{5}$, foi proposta por CUBILLOS (1986) as seguintes correlações:

\section{Lagoas Facultativas Primárias}

$$
\lambda_{r}=25,133+0,675^{\star} \lambda_{s}
$$

válida para o intervalo:

$79 \leq \lambda_{s} \leq 594 \mathrm{kgDBO} / \mathrm{ha}^{*} \mathrm{~d}$ 


\section{Lagoas Facultativas Secundárias}

$$
\lambda_{r}=-3,8179+0,8167 * \lambda_{s}
$$

válida para o intervalo:

$29,4 \leq \lambda_{s} \leq 249,2 \mathrm{kgDBO} / \mathrm{ha}^{*} \mathrm{~d}$

\section{Lagoas Facultativas Terciárias}

$$
\lambda_{r}=3,6832+0,6284 * \lambda_{s}
$$

válida para o intervalo:

$39,1 \leq \lambda_{s} \leq 82,1 \mathrm{kgDBO} / \mathrm{ha}^{*} \mathrm{~d}$

\subsubsection{Resíduos gerados nos lagoas de estabilização}

O tratamento $\theta$ a disposição final do lodo constituem problemas de grande complexidade, face ao grande volume gerado, às dificuldades em se encontrar locais adequados e seguros, altos custos de transporte e as características de operação e processo. As orientações quanto à gestão que incluem: redução de produção, aumento máximo de reutilização, reciclagem e a promoção de tratamento ambientalmente saudável, foram definidas pela Agenda 21, sob o título "Manejo ambientalmente saudável dos resíduos sólidos e questões relacionadas com esgoto" (VON SPERLING 1999).

O termo lodo é utilizado para caracterizar os sub-produtos sólidos gerados no tratamento de esgotos (em conjunto com sólidos grosseiros, areia e escuma), resultantes das atividades biológicas do sistema e, segundo JORDÂO e PESSOA (1995), os lodos devem receber atenção especial em seu tratamento.

AISSE et al (1999) comentam que, dependendo da natureza e origem dos sólidos, os lodos podem ser definidos como: lodos primários, 
gerados a partir da sedimentação de material particulado do afluente e, lodos secundários, resultantes da absorção e conversão da matéria orgânica, fazendo parte integrante da biomassa microbiana.

No Brasil, pela falta de dados consistentes referentes à produção e disposição final do lodo, os mesmos são estimados a partir das populações beneficiadas com a coleta $\theta$ tratamento. Considerando-se 0 atendimento de esgoto sanitário de 87 milhões de habitantes por sistema (BIO 2001) $\theta$, supondo que todos esses sistemas incluíssem 0 tratamento, seriam obtidos os seguintes valores de produção de lodo, calculados em função de valores médios de produção per capita de diversos processos anaeróbios e aeróbios (VON SPERLING 1999):

90.000 a 350.000 toneladas por dia de lodo líquido a ser tratado (produção per capita volumétrica de cerca de 1 a 4 Vhab. dia);

9.000 a 13.000 toneladas por dia de lodo desaguado a ser disposto (produção per capita volumétrica de cerca de 0,1 a 0,15 Vhab. dia).

Por apresentar características indesejáveis, o principal objetivo do tratamento de lodo visa: reduzir o material biodegradável por meio de aplicação de digestão anaeróbia, eliminar e/ou reduzir; especialmente em casos de esgotos sanitários, uma grande variedade de vírus, bactérias e parasitas (protozoários, ovos de nematóides e helmintos), reduzir teor de água, processo de separação de fases, pois a concentração de sólidos nos lodos é relativamente baixa e o seu volume é considerável. O quadro 5.13 apresenta valores de concentração de sólidos, além de outros constituintes de lodo biológico aeróbio e lodo primário digerido de sistemas de tratamento de esgotos (AISSE et al 1999). 
Quadro 5.13 Composição química e algumas propriedades típicas de lodo de esgoto.

\begin{tabular}{c|c|c|c|c|c}
\hline \multirow{2}{*}{ Item } & Unidade & \multicolumn{2}{c|}{ Lodo secundário } & \multicolumn{2}{c}{ Lodo primário digerido } \\
\hline & & faixa & típico & faixa & Típico \\
\hline Sólidos totai & $\%$ & $2,0-8,0$ & 5,0 & $6,0-12,0$ & 10,0 \\
\hline $\begin{array}{c}\text { Sólidos } \\
\text { voláteis }\end{array}$ & $\%$ de ST & $60-80$ & 65 & $30-60$ & 40 \\
\hline Nitrogênio & $\%$ de ST & $1,5-4,0$ & 2,5 & $1,6-6,0$ & 3,0 \\
\hline Fósforo & $\%$ de ST & $0,8-2,8$ & 1,6 & $1,5-4,0$ & 2,5 \\
\hline Potássio & $\%$ de ST & $0-1$ & 0,4 & $0-3,0$ & 1,0 \\
\hline pH & & $5,0-8,0$ & 6,0 & $6,5-7,5$ & 7,0 \\
\hline Alcalinidade & $\mathrm{mg} \mathrm{CaCO}_{3} \mathrm{~L}$ & $500-1500$ & 600 & $2500-3500$ & 3000 \\
\hline
\end{tabular}

FONTE: AISSE et al (1999)

\subsubsection{Dados e resultados operacionais de lagoas anaeróbias e facultativas}

KAWAI (1981), realizou estudos em lagoas anaeróbias com vários tempos de detenção e chegou à conclusão, conforme tabela 5.7, que as lagoas tendem a funcionar como facultativa com tempos superiores a seis dias.

Quanto à eficiência e qualidade do efluente, vários estudos realizados em diversas estações de tratamento utilizando associações de lagoas anaeróbias-facultativas secundárias ou facultativas primáriassecundárias apresentaram os seguintes resultados, apresentados nas tabelas 5.1 a 5.5 (CETESB 1989). 
Tabela 5.1 Levantamento de dados operacionais em várias lagoas anaeróbias dos Estados de São Paulo e Paraná.

\begin{tabular}{c|c|c|c|c}
\hline Localidade & $\begin{array}{c}\text { Temperatura } \\
\text { da lagoa } \\
\left({ }^{\circ} \mathrm{C}\right)\end{array}$ & $\begin{array}{c}\text { Tempo } \\
\text { de } \\
\text { detenção }\end{array}$ & $\begin{array}{c}\text { Taxas } \\
\text { volumétricas } \\
\text { kgDBO/d.m }\end{array}$ & $\begin{array}{c}\text { Eficiência } \\
\text { de remoção } \\
\text { DBO }(\%)\end{array}$ \\
\hline Itapira & 23,3 & 9,4 & 0,025 & 68 \\
\hline Pindamonhangaba & 24,2 & 3,6 & 0,039 & 42 \\
\hline Pradópolis & 25,2 & 7,5 & 0,035 & 72 \\
\hline Itapira & 18 & 10,5 & 0,03 & 57 \\
\hline Maringá & 21,6 & 10,5 & 0,033 & 71 \\
\hline Maringá & 19,5 & 8,3 & 0,044 & 75 \\
\hline Maringá & 24,9 & 7,2 & 0,058 & 74 \\
\hline Maringá & 25,1 & 4,8 & 0,081 & 67 \\
\hline Tatuí & 25,2 & 1,2 & 0,192 & 31 \\
\hline
\end{tabular}

FONTE: KAWAI (1981).

Tabela 5.2 Lagoas de estabilização de Mairiporã (SP) coleta janeiro de 1976 a março de 1977.

\begin{tabular}{c|c|r|r|r|r|r|c}
\hline Parâmetros & Unidade & \multicolumn{3}{c|}{$1^{\circ}$ semestre 1976} & \multicolumn{3}{c}{$3^{\circ}$ semestre 1976} \\
\hline & & A.A & E.A & E.F & A.A & E.A & E.F \\
\hline Temp. Esgoto $\left({ }^{\circ} \mathrm{C}\right)$ & & 24,5 & 25 & 27 & 19,5 & 19,5 & 19,0 \\
\hline pH & & 6,5 & 6,8 & 8,4 & 6,8 & 6,8 & 8,0 \\
\hline DBO & $\mathrm{mg} / \mathrm{L}$ & 320 & 50 & 45 & 300 & 145 & 45 \\
\hline DQO & $\mathrm{mg} / \mathrm{L}$ & 525 & - & 142 & 460 & - & 143 \\
\hline Sólidos totais & $\mathrm{mg} / \mathrm{L}$ & 695 & 304 & 331 & 531 & 290 & 276 \\
\hline Sólidos voláteis & $\mathrm{mg} / \mathrm{L}$ & 397 & 165 & 209 & 326 & 166 & 163 \\
\hline S. Sedimentáveis & $\mathrm{mg} / \mathrm{L}$ & 5,0 & 0,1 & 0,1 & 4,3 & 0,1 & 0,1 \\
\hline
\end{tabular}

FONTE: CETESB (1989) 
Tabela 5.3 Determinação de série nitrogenada e fosfato solúvel nas lagoas de Mairiporã (SP) - maio 1977.

\begin{tabular}{c|c|c|c|c|c|c|c|c|c}
\hline \multirow{2}{*}{ Parâmetros } & \multicolumn{3}{|c|}{ Afluente anaer. } & \multicolumn{3}{c|}{ Efluente anaer. } & \multicolumn{3}{c}{ Efluente final } \\
\cline { 2 - 9 } & Máx. & Méd. & Mín. & Máx. & Méd. & Mín. & Máx. & Méd. & Mín. \\
\hline $\begin{array}{c}\text { Fosfato solúvel } \\
\text { (mg/ P) }\end{array}$ & 8,0 & 6,6 & 5,8 & 6,4 & 4,9 & 4,3 & 2,2 & 2,0 & 1,7 \\
\hline $\begin{array}{c}\text { Nitrog. Amoniacal } \\
(\mathrm{mg} / \mathrm{N})\end{array}$ & 48,6 & 43,2 & 35,0 & 36,8 & 35,9 & 35,2 & 25,0 & 23,3 & 21,6 \\
\hline $\begin{array}{c}\text { Nitrog. Nitrato } \\
(\mathrm{mg} / \mathrm{N})\end{array}$ & 0,11 & 0,06 & 0,02 & 0,08 & 0,005 & 0,03 & 0,09 & 0,07 & 0,06 \\
\hline $\begin{array}{c}\text { Nitrog. Nitrito } \\
(\mathrm{mg} / \mathrm{N})\end{array}$ & 0,005 & 0,003 & 0,001 & 0,03 & 0,001 & - & 0,038 & 0,004 & \\
\hline
\end{tabular}

FONTE: CETESB (1989)

Tabela 5.4 Resultados operacionais lagoas de Mairiporã (SP).

\begin{tabular}{|c|c|c|c|c|c|c|}
\hline \multicolumn{7}{|c|}{ Lagoa Anaeróbia } \\
\hline Período & $\begin{array}{l}\text { Vazão média } \\
\text { Afluente (V/s) }\end{array}$ & $\begin{array}{l}\text { TDH } \\
\text { (dias) }\end{array}$ & $\begin{array}{c}\text { Carga } \\
\text { orgânica } \\
\text { (kgDBO/had) }\end{array}$ & $\begin{array}{c}\text { DBO } \\
\text { Afluente } \\
(\mathrm{mg} / \mathrm{l})\end{array}$ & $\begin{array}{c}\text { DBO } \\
\text { Efluente } \\
(\mathrm{mg} / \mathrm{l})\end{array}$ & $\begin{array}{c}\text { Redução } \\
\text { (\%) }\end{array}$ \\
\hline $1^{\circ}$ trimestre 1976 & 8,5 & 10,4 & 919 & 320 & 50 & 84,37 \\
\hline $2^{\circ}$ trimestre 1976 & 13,0 & 6,8 & 1580 & 360 & 115 & 68,05 \\
\hline $3^{\circ}$ trimestre 1976 & 13,0 & 6,8 & 1318 & 300 & 145 & 52,66 \\
\hline $4^{\circ}$ trimestre 1976 & 13,8 & 7,4 & 1013 & 250 & 60 & 76,00 \\
\hline $1^{\circ}$ trimestre 1977 & 18,0 & 4,9 & 1557 & 260 & 55 & 78,84 \\
\hline \multicolumn{7}{|c|}{ Lagoa facultativa } \\
\hline Período & $\begin{array}{l}\text { Vazão média } \\
\text { Afluente (V/s) }\end{array}$ & $\begin{array}{l}\text { TDH } \\
\text { (dias) }\end{array}$ & $\begin{array}{c}\text { Carga } \\
\text { orgânica } \\
\text { (kgDBO/had) }\end{array}$ & $\begin{array}{c}\text { DBO } \\
\text { Afluente } \\
\text { (mg/l) }\end{array}$ & $\begin{array}{c}\text { DBO } \\
\text { Efluente } \\
\text { (mgll) }\end{array}$ & $\begin{array}{c}\text { Redução } \\
\text { (\%) }\end{array}$ \\
\hline $1^{\circ}$ trimestre 1976 & 8,0 & 15,8 & 31,5 & 50,0 & 45 & 10,0 \\
\hline $2^{\circ}$ trimestre 1976 & 13,0 & 10,3 & 110,80 & 115,0 & 65 & 43,47 \\
\hline $3^{\circ}$ trimestre 1976 & 13,0 & 10,3 & 138,12 & 145,0 & 45 & 68,96 \\
\hline $4^{\circ}$ trimestre 1976 & 12,0 & 11,2 & 53,36 & 60,0 & 40 & 33,34 \\
\hline $1^{\circ}$ trimestre 1977 & 18,0 & 7,5 & 73,37 & 55 & 40 & 27,27 \\
\hline
\end{tabular}

FONTE: CETESB (1989) 
Tabela 5.5 Lagoas de estabilização de Guará (Brasília).

\begin{tabular}{|c|c|c|c|c|c|c|c|c|c|}
\hline \multirow{2}{*}{ Parâmetros } & \multicolumn{3}{|c|}{ Máximo } & \multicolumn{3}{|c|}{ Médio } & \multicolumn{3}{|c|}{ Mínimo } \\
\hline & A.A & E.A & E.F & A.A & E.A & E.F & A.A & E.A & E.F \\
\hline Temp. $\operatorname{ar}\left({ }^{0} \mathrm{C}\right)$ & 26 & 26 & 27 & 23,3 & 23,3 & 23,3 & 18,5 & 18,5 & 18,5 \\
\hline Temp. esgoto $\left({ }^{\circ} \mathrm{C}\right)$ & 24,5 & 28 & 26 & 23,4 & 23,9 & 23,9 & 22 & 21 & 21 \\
\hline $\mathrm{DBO}(\mathrm{mg} / \mathrm{l})$ & 680 & 450 & 200 & 465 & 174 & 103 & 360 & 40 & 50 \\
\hline DQO (mg/l) & 1538 & 923 & 513 & 1132 & 613 & 311 & 726 & 302 & 109 \\
\hline Nitrog. Amon (mg/l) & 49,6 & 21,0 & 11,8 & 40,5 & 14,6 & 8,7 & 17,5 & 7,0 & 6,3 \\
\hline ST (mg/l) & 884 & 300 & 430 & 557 & 258 & 232 & 337 & 215 & 116 \\
\hline STF (mg/) & 400 & 131 & 134 & 194 & 84 & 71 & 109 & 24 & 6 \\
\hline STV (mg/l) & 662 & 246 & 220 & 226 & 165 & 170 & 195 & 108 & 44 \\
\hline SS (mgl) & 380 & 164 & 224 & 253 & 86 & 78 & 90 & 40 & 32 \\
\hline SD (mg/l) & 573 & 245 & 249 & 295 & 164 & 166 & 173 & 56 & 83 \\
\hline S.Sedim.(mg/) & 12 & & & 6,20 & & & 1,5 & & \\
\hline O.D. (mg/l) & & & 15,7 & & & 7,6 & & & $\overline{1,1}$ \\
\hline
\end{tabular}

FONTE: CETESB (1989)

\subsubsection{Produção de lodo em lagoas anaeróbias e facultativas}

Apesar do inevitável acúmulo de lodo em lagoas de estabilização, o gerenciamento é raramente considerado parte integrante do processo. Uma das razões para o descaso é a falta de informações sobre taxas de acumulação, distribuição do lodo dentro das lagoas e características próprias (NELSON et al 2004).

Segundo GONÇALVES (1999), a forma como os resíduos sólidos se distribuem ao longo da lagoa são obtidos a partir de estudos de taxas de acumulações de lodo, auxiliando assim, na determinação da freqüência de remoção e condições viáveis de disposição desse material.

NELSON (2004) ressalta que, a maior quantidade de lodo produzida é observada em lagoas primárias $\theta$, em função das alterações das características hidráulicas da lagoa, como por exemplo, redução do 
volume útil e tempo de detenção hidráulico, o acúmulo desses resíduos sólidos acaba interferindo na eficiência do sistema.

O cálculo do volume per capita de lodo produzido por dia é feito tendo como base a carga per capita diária e concentração de sólidos secos, conforme tabela 5.6 (VON SPERLING 2001).

Tabela 5.6 Características e quantidade do lodo produzido em vários sistemas de tratamentos de esgoto.

\begin{tabular}{c|c|c|c|c}
\hline Sistema & \multicolumn{4}{|c}{ Características do lodo produzido e descartado da } \\
fase líquida
\end{tabular}

FONTE: adaptado SPERLING (2001)

Conforme ITO (2002), a taxa de produção de lodo propostas por literaturas nem sempre condizem com a realidade. A divergência entre 
resultados teóricos e práticos se deve, às vezes, pela variação da vazão afluente a lagoa ao longo de seu período de operação (Tabela 5.13).

Tabela 5.7 Taxa de produção de lodo.

\begin{tabular}{|c|c|c|c|c|}
\hline \multirow{2}{*}{ Autor } & \multicolumn{3}{|c|}{ Taxa de acúmulo de lodo } & \multirow{2}{*}{ Tipo de lagoa } \\
\hline & I/hab.dia & $\mathrm{m}^{3}$ /hab.and & cm/ano & \\
\hline Gloyna (1973) & 0,34 & & & Anaeróbia \\
\hline $\begin{array}{c}\text { Gloyna apud Arceivala } \\
\text { (1981) }\end{array}$ & & $0,03-0,05$ & & \\
\hline Mara (1979) & & $0,03-0,04$ & & $\begin{array}{l}\text { Anaeróbia/ } \\
\text { Primária }\end{array}$ \\
\hline Hess (1975) & 0,26 & & & Anaeróbia \\
\hline Siva e Mara (1979) & 0,11 & & & Anaeróbia \\
\hline Arceivala (1983) & $0,08-0,22$ & & & Anaeróbia \\
\hline Da Rin (1988) & 0,1 & & & Facultativa \\
\hline Mendonça (1990) & $0,08-0,11$ & & & Anaeróbia \\
\hline \multirow{2}{*}{ Senra (1983) } & & & $7,3-15,3$ & $\begin{array}{l}\text { Anaeróbia } \\
\text { (20 anos) }\end{array}$ \\
\hline & & & $1,22-2,77$ & $\begin{array}{l}\text { Facultativa } \\
\text { secund. }\end{array}$ \\
\hline $\begin{array}{c}\text { Tsutya e Cassetari } \\
\text { (1995) }\end{array}$ & & & 3,9 & $\begin{array}{l}\text { Anaeróbia } \\
\text { (12 anos) } \\
\end{array}$ \\
\hline $\begin{array}{c}\text { Tsutya e Cassetari } \\
\text { (1995) }\end{array}$ & & & 2,2 & $\begin{array}{l}\text { Facultativa } \\
\text { (12 anos) }\end{array}$ \\
\hline Silva (1983) & & & 5,7 & $\begin{array}{l}\text { Anaeróbia } \\
\text { (3 anos) }\end{array}$ \\
\hline Silva (1983) & & & 2,18 & $\begin{array}{c}\text { Anaeróbia } \\
\text { (8 anos) }\end{array}$ \\
\hline Saqqar e Pescod (1995) & & & 46 & Anaeróbia \\
\hline Nascimento (1999) & $\begin{array}{l}0,023- \\
0,026 \\
\end{array}$ & & $5,35-7,6$ & $\begin{array}{l}\text { Anaeróbia } \\
\text { (15 anos) }\end{array}$ \\
\hline \multirow{2}{*}{$\begin{array}{c}\text { Muller (1999) } \\
\text { Lagoa de Eldorado }\end{array}$} & & & 7,66 & Anaeróbia \\
\hline & & & 0,23 & Facultativa \\
\hline
\end{tabular}

FONTE: ITO (2002) 
Medições da espessura de lodo realizadas por SILVA (1983) em lagoas anaeróbias e secundárias localizadas no município de Tatuí (SP), quando comparadas duas lagoas anaeróbias operando com três $\theta$ oito anos, demonstraram uma variação de $5,7 \mathrm{~cm} /$ ano e $2,18 \mathrm{~cm} / \mathrm{ano}$ respectivamente. Segundo o autor, a espessura de $5,7 \mathrm{~cm}$ foi constatada na lagoa que recebia contribuições indevidas de águas pluviais na rede coletora. Nas lagoas facultativas secundárias, subseqüentes as anaeróbias com mesmo período de operação, a lagoa com maior tempo de operação apresentou espessura média $9,78 \mathrm{~cm}$ de camada de lodo (1,22 cm/ano), já na lagoa com três anos de operação a espessura média de lodo alcançou a marca de $8,33 \mathrm{~cm}(2,77 \mathrm{~cm} / \mathrm{ano})$.

Nas tabelas 5.8 e 5.9 podem ser observadas as características principais do lodo presentes nas lagoas anaeróbias e facultativas secundárias.

Tabela 5.8 Características dos lodos acumulados nas lagoas anaeróbias do município de Tatuí.

\begin{tabular}{|c|c|c|c|c|c|c|}
\hline \multirow[b]{2}{*}{ Determinações } & \multicolumn{6}{|c|}{ Pontos de amostragem } \\
\hline & 1 & 3 & 5 & 6 & 8 & 11 \\
\hline $\begin{array}{c}\text { Altura da camada de } \\
\text { lodo }(\mathrm{cm})\end{array}$ & 15 & 18 & 18 & 16 & 18 & 18 \\
\hline $\mathrm{pH}$ & 6,8 & 7,8 & 6,7 & 6,8 & 6,5 & 6,9 \\
\hline Ácidos voláteis (mg/l) & 20 & 20 & 40 & 30 & 30 & 40 \\
\hline Acalinidade total (mg/l) & 320 & 400 & 300 & 140 & 200 & 150 \\
\hline Sólidos totais (mg/l) & 23020 & 28400 & 16500 & 23390 & 24500 & 16400 \\
\hline $\begin{array}{c}\text { Sólidos totais fixos } \\
\text { (mg/l) }\end{array}$ & 12020 & 10200 & 6300 & 4400 & 6090 & 6820 \\
\hline $\begin{array}{l}\text { Sólidos totais voláteis } \\
(\mathrm{mg} / \mathrm{l})\end{array}$ & 3500 & 5200 & 4700 & 3990 & 4410 & 5580 \\
\hline $\begin{array}{l}\text { Temperatura do lodo } \\
\left({ }^{\circ} \mathrm{C}\right)\end{array}$ & 24 & 24 & 24 & 24 & 24 & 24 \\
\hline $\begin{array}{l}\text { Altura da lâmina deágua } \\
(\mathrm{m})\end{array}$ & 1,60 & 1,60 & 1,60 & 1,60 & 1,60 & 1,60 \\
\hline
\end{tabular}

FONTE: SILVA (1983) 
Tabela 5.9 Características dos lodos acumulados nas lagoas facultativas secundárias do município de Tatuí

\begin{tabular}{|c|c|c|c|c|c|c|}
\hline \multirow[b]{2}{*}{ Determinações } & \multicolumn{6}{|c|}{ Pontos de amostragem } \\
\hline & 18 & 20 & 22 & 23 & 25 & 27 \\
\hline $\begin{array}{c}\text { Altura da camada de } \\
\text { lodo }(\mathrm{cm})\end{array}$ & 8 & 10 & 16 & 6 & 9 & 8 \\
\hline $\mathrm{pH}$ & 6,5 & 6,7 & 6,4 & 6,3 & 6,6 & 6,3 \\
\hline Ácidos voláteis mg/l) & 50 & 40 & 20 & 10 & 30 & 50 \\
\hline Acalinidade total $(\mathrm{mg} / \mathrm{l})$ & 150 & 250 & 110 & 260 & 380 & 140 \\
\hline Sólidos totais $(\mathrm{mg} / \mathrm{l})$ & 3670 & 3450 & 3770 & 3220 & 3389 & 5560 \\
\hline $\begin{array}{c}\text { Sólidos totais fixos } \\
\text { (mg/l) }\end{array}$ & 1600 & 1340 & 1620 & 1240 & 1370 & 2540 \\
\hline $\begin{array}{l}\text { Sólidos totais voláteis } \\
(\mathrm{mg} / \mathrm{l})\end{array}$ & 2070 & 2110 & 2150 & 1980 & 2010 & 3020 \\
\hline $\begin{array}{c}\text { Temperatura do lodo } \\
\left({ }^{\circ} \mathrm{C}\right)\end{array}$ & 24 & 24 & 24 & 24 & 24 & 24 \\
\hline $\begin{array}{l}\text { Altura da lâmina deágua } \\
(\mathrm{m})\end{array}$ & 1,20 & 1,20 & 1,20 & 1,20 & 1,20 & 1,20 \\
\hline
\end{tabular}

FONTE: SILVA (1983)

Estudos desenvolvidos por NELSON (2004) no México, em 4 sistemas de lagoas de estabilização, demonstraram a taxa de acumulação do lodo determinada por base per capita e média anual do aumento da espessura do lodo (tabela 5.10).

Nas lagoas de estabilização existentes no México, a média da taxa de acumulação per capita se situa entre 0,021 e 0,036 m3/hab.d. Essas taxas são similares a valores observados na Colômbia e no Brasil, entretanto, esses valores são bem inferiores ao encontrados em países, como por exemplo, França, provavelmente em função das baixas temperaturas registradas naquele país. Outros fatores também influenciam a taxa de acumulação de lodo per capita: despejos industriais, águas pluviais $e$ infiltração. Embora os dados de campo sejam insuficientes, o valor de $0,04 \mathrm{~m}^{3}$ /hab.dia é o mais recomendado 
para projetos de lagoas anaeróbias localizadas em locais com temperatura média de $20^{\circ} \mathrm{C}$ (NELSON 2004).

Tabela 5.10 Concentração de sólidos no lodo e taxas de acumulação em diversas lagoas de estabilização.

\begin{tabular}{c|c|c|c|c|c|c}
\hline Localidade & Tipo de lagoa & $\begin{array}{c}\text { Tempo } \\
\text { de } \\
\text { operação } \\
(\text { anos })\end{array}$ & $\begin{array}{c}\text { Sólidos } \\
\text { totais } \\
(g / L)\end{array}$ & $\begin{array}{c}\text { Relação } \\
\text { SV/SF } \\
(\%)\end{array}$ & \multicolumn{2}{|c}{$\begin{array}{c}\text { Taxas de } \\
\text { acumulação }\end{array}$} \\
\hline Mexicaltzingo & Anaeróbica & 5 & 171 & 63 & 0,022 & 119 \\
\hline San Jose & Facultativa & 6 & $N A$ & $N A$ & 0,036 & 21 \\
\hline Texcoco & Facultativa & 10 & 112 & 57 & NA & 21 \\
\hline Xalostoc & Facultativa & 15 & 166 & 67 & 0,021 & 19 \\
\hline
\end{tabular}

FONTE: NELSON (2004)

\subsection{Estimativa da formação de lodo em lagoas anaeróbias e facultativas}

A quantidade de lodo, freqüência de remoção, como desidratá-lo, transportá-lo e dispô-lo são questões primordiais na fase de tratamento e integra de maneira significativa o custo operacional da ETE (GONÇALVES 1999).

\subsection{Estimativa através de taxas empíricas}

Conforme GONÇALVES (1999), as taxas empíricas de acumulação de lodo podem ser expressas em termos de:

$>$ Volume de lodo acumulado por unidade de tempo per capita (m3/hab.ano ou Vhab.d)

$>$ Altura acumulada de lodo por unidade de tempo (cm/ano) 
A taxa volumétrica "per capita" de acumulação de lodo é definida pela equação:

$$
t_{v}=\left(1000^{*} V\right) /(P * T)
$$

Onde:

$t_{v}=$ taxa volumétrica "per capita" de acumulação de lodo (//hab.d)

$V=$ volume de lodo acumulado no período considerado $\left(\mathrm{m}^{3}\right)$

$P=n^{0}$ de habitantes com ligação à rede coletora que contribui para ETE (hab)

$T$ = tempo de operação da lagoa, decorrido desde a última batimetria (dias).

A taxa de acumulação linear de acumulação de lodos com relação à altura da camada de lodos é definida pela expressão

$$
\left(t_{L}=h / T\right)
$$

Onde:

$t_{L}=$ taxa linear de acumulação de lodos (cm/ano)

$\mathrm{h}=$ altura média da camada de lodos $(\mathrm{cm})$

$T=$ tempo de operação da lagoa, decorrido desde a última batimetria.

As taxas volumétricas de lodo são empregadas para se estimar a altura de camada de lodo formada. Conforme JORDÃO e PESSOA (1995), essas taxas variam entre 0,08 $\Theta 0,4$ Vhab.d em lagoas primárias (anaeróbias ou facultativas). Em locais de clima quente são utilizadas as taxas inferiores, ao contrário de regiōes de clima frio onde são aplicadas taxas superiores. Mesmo utilizando o limite superior, os resultados apresentados de produção de lodo "per capita" em lagoas de estabilização são inferiores quando comparados com outros processos de tratamento (tabela 5.11). 
Tabela 5.11 Estimativa de produção de lodo em diferentes processos de tratamento de esgotos sanitários.

\begin{tabular}{c|c|c|c|c|c}
\hline Tipo de lodo & Densidade & \multicolumn{2}{|c|}{$\begin{array}{c}\text { Sólidos secos } \\
\left(\mathrm{kg} / \mathrm{m}^{3}\right)\end{array}$} & \multicolumn{2}{c}{ Lodo úmido } \\
\hline & & Faixa & Típico & Uhab.d & $\begin{array}{c}\mathbf{m}^{3} / 1000 \\
\mathbf{m}^{3}\end{array}$ \\
\hline Lodo primário & 1,020 & $108-168$ & 150 & $0,5-1,0$ & 3 \\
\hline $\begin{array}{c}\text { Filtro } \\
\text { biológico perc. }\end{array}$ & 1,025 & $60-95$ & 70 & $0,6-0,7$ & 4, \\
\hline $\begin{array}{c}\text { Lodos } \\
\text { ativados conv. }\end{array}$ & 1,005 & $70-95$ & 85 & $1,5-4,5$ & 10,5 \\
\hline $\begin{array}{c}\text { Lodos } \\
\text { ativados aera. } \\
\text { Prolong. }\end{array}$ & 1,015 & $85-120$ & 95 & $1,0-3,0$ & 7 \\
\hline
\end{tabular}

FONTE: JORDÃO E PESSOA (1995)

\subsection{Estimativa através do modelo de SAQQAR \& PESCOD}

$\mathrm{Na}$ determinação da produção de lodo em lagoas primárias, a maioria dos modelos racionais considera que o volume de lodo acumulado é controlado pela fração não biodegradável dos sólidos sedimentáveis que entram no sistema e os que são produzidos pelas atividades biológicas dos microorganismos (GONÇALVES 1999).

No modelo desenvolvido por SAQQAR e PESCOD (1995) apud GONÇALVES (1999), o objetivo principal é estimar o acúmulo de lodo em lagoas anaeróbias (figura 5.6). A taxa de acumulação $\left(F_{L}\right)$ de lodos é definida pelo balanço de massa que considera a carga de sólidos suspensos na entrada, a carga de sólidos na saída $\theta$ a produção de sólidos por ação biológica na lagoa. 


$$
F L=\left(F_{x s s, 0}-F_{x s s, 1}\right)+D F_{x}
$$

Onde:

$\mathrm{FL}=$ taxa de acumulação de lodo na lagoa

$F_{X S s, 0}=$ carga de sólidos suspensos na entrada da lagoa $(\mathrm{kg} / \mathrm{d})$

$F_{x s s, 1}=$ carga de sólidos suspensos na saída da lagoa ( $\left.\mathrm{kg} / \mathrm{d}\right)$

$D F_{X}=$ taxa de produção de sólidos por ação biológica $(\mathrm{kg} / \mathrm{d})$

A produção de sólidos na camada de lodo decorrente do metabolismo bacteriano é definida por:

$$
D F_{X}=Y D F_{D B O}=Y\left(F_{C D B O, O}-F_{C D B O, 1}\right)
$$

Onde:

$\mathrm{Y}=$ coeficiente de rendimento $(\mathrm{kg} \mathrm{SS} / \mathrm{kg} \mathrm{DBO} 5)$

$F_{\mathrm{CDBO}, 0}=$ carga de DBO 5 na entrada da lagoa ( $\mathrm{kg} /$ dia)

$\mathrm{F}_{\mathrm{CDBO}, 1}=$ carga de DBO5 na saída da lagoa $(\mathrm{kg} / \mathrm{d})$

Levando em consideração que os sólidos suspensos $\left(X_{S s}\right)$ podem ser divididos em sólidos suspensos voláteis $\left(X_{v s s}\right)$ e sólidos suspensos fixos ( $X_{F S S}$ ), a equação da taxa de acumulação de lodo na lagoa pode ser descrita da seguinte forma:

$$
F L=\left(F_{X V S S, 0}-F_{X V S S, 1}\right)+\left(F_{X F S S, 0}-F_{X F S S, 1}\right)+Y\left(F_{C D B O, 0}-F_{C D B O, 1}\right)(5.24)
$$

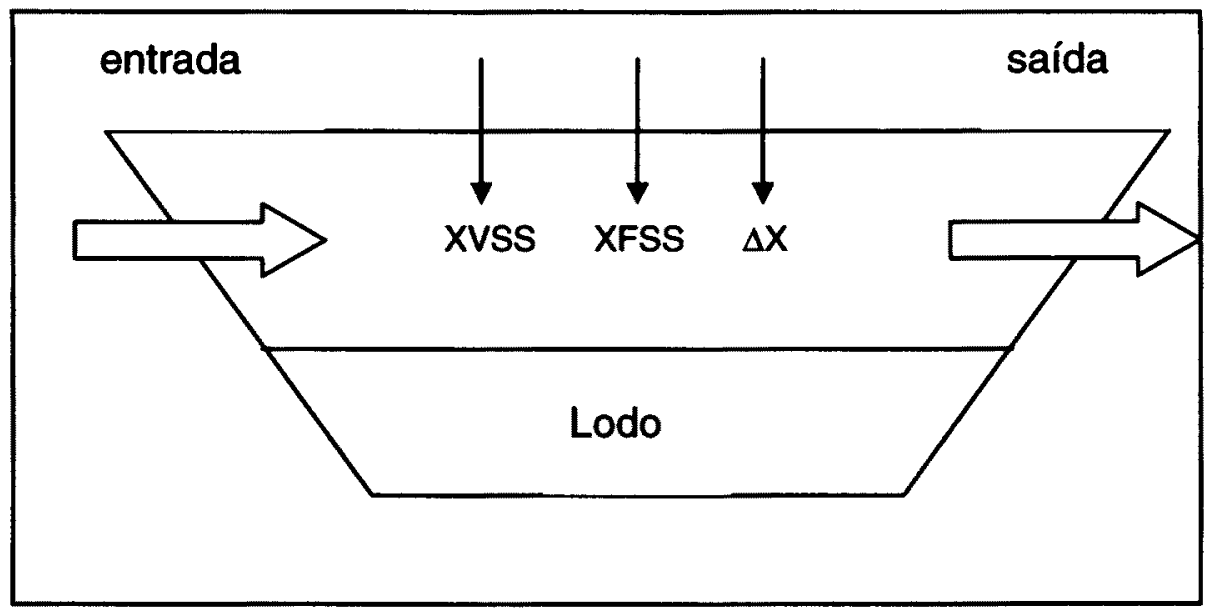

Figura 5.6 Esquema do modelo previsto por SAQQAR e PESCOD

FONTE: (GONÇALVES, 1999) 
O volume de lodo acumulado diariamente na lagoa pode ser estimado através da equação abaixo:

$$
Q_{A S}=\left[\frac{\left(11^{\star} f 1\right)^{\star}\left(F_{X V S S .0}\right)+\left(i 2^{*} f 2\right)^{*}\left(F_{X F S S .0}\right)+\left(i 3^{*} f 3\right)^{*}\left(F_{C D B O .0}\right)}{\left[S G_{S}^{*} \rho_{\omega}^{*}\left(1-\omega_{S}\right)\right]}\right]
$$

Onde:

$\mathrm{Q}_{\mathrm{AS}}=$ volume de lodo acumulado diariamente na lagoa $\left(\mathrm{m}^{3} / \mathrm{dia}\right)$

$\mathrm{SG}_{\mathrm{S}}=$ massa específica do lodo

$\rho_{\omega}=$ densidade da água $1000 \mathrm{~kg} / \mathrm{m}^{3}$

$\omega_{S}=$ teor de umidade do lodo (\%)

f1 = fração de Fxvss, o removida da lagoa

12 = fração de FXFs, $0_{0}$ removida da lagoa

f3 = fração de $F_{C D B O, 0}$ removida da lagoa

j1 = fração de Fxvss não destruída por digestão anaeróbia na lagoa

j2 = fração de $F_{X F S s}$ não destruída por digestão anaeróbia na lagoa

j3 = fração de sólidos biológicos produzidos e não destruída por digestão anaeróbia.

Considerando constante o denominador da equação 5.25 , o volume de lodo pode ser calculado conforme:

$$
\begin{aligned}
& Q_{A S}=\frac{g 1^{*}\left(F_{X Y S S .0}\right)+g 2^{*}\left(F_{X F S S .0}\right)+g 3^{*}\left(F_{C D B O}\right)}{1000} \\
& g 1=(j 1 * f 1) /\left[\left(S G S^{*} \rho_{\omega}^{*}\left(1-\omega_{S}\right)\right]\right. \\
& g 2=(j 2 *+2) /\left[\left(S G S^{*} \rho_{\omega}^{*}\left(1-\omega_{S}\right)\right]\right. \\
& g 3=\left(j 3^{*}+3\right) /\left[\left(S G S^{*} \rho_{\omega}^{*}\left(1-\omega_{S}\right)\right]\right.
\end{aligned}
$$

Conforme GONÇALVES (1999), pelo fato da lagoa operar de forma semelhante a um digestor anaeróbio de lodo, na falta de dados experimentais, poderão ser utilizados os seguintes valores teóricos. 
$f 1=0,74$ (eficiência de remoção de sólidos na lagoa estudada)

f2 $=0,74$ (eficiência de remoção de sólidos na lagoa estudada)

$\mathrm{f} 3=0,53$ (valor médio determinado por SAQQAR e PESCOD)

$\mathrm{j} 1$ = 0,3 (destruição de $X_{\mathrm{Vss}, 0}$ em um digestor com TDH>100dias)

j2 $=0,8$ (destruição de $X_{F s s, 0}$ em um digestor com TDH>100dias)

j3 $=0,50$ (composição das células bacterianas: SSV $=60 \%$ e $S S F=40 \%)$

$Y=0,50$ (coeficiente de rendimento para digestão anaeróbia)

$\omega_{S}=0,88$ (lodo da lagoa estudada pelos autores)

$S G_{S}=1,03$ (determinado pelos autores)

Substituindo os dados apresentados acima nas equações (5.27), (5.28) e (5.29), o volume de lodo acumulado por ser estimado por:

$$
V_{A S}=1,07^{*}\left[\frac{\left(1,7^{*} F_{X V S S .0}\right)+4.5^{*}\left(F_{\text {XESS } .0}\right)+1,0^{*}\left(F_{\text {CDBO } .0)}\right)}{1000}\right]
$$

SAQQAR e PESCOD (1995) alegam que, a degradação dos sólidos na camada de lodos de uma lagoa ocorre durante períodos muito longos ( $>5$ anos), permitindo a decomposição do material orgânico muito lentamente biodegradável. Sendo assim, o volume obtido na equação 5.26 , sofrerá redução através de uma fómula mais genérica.

$$
V_{A S}=K_{A S} * \frac{\left(1,7^{*} F_{X V S S .0}\right)+4.5^{*}\left(F_{X F S S .0}\right)+1,0^{*}\left(F_{C D B O, 0}\right)}{1000}
$$

Onde:

$\mathrm{K}_{\mathrm{AS}}=$ coeficiente de acumulação de lodo.

Conhecendo-se as características médias do esgoto a ser tratado ( $F_{X V S S, 0,} F_{X F S S, 0}, F_{C D B O, 0}$ ), o cálculo do valor $V_{A S}$ toma-se mais simples. Valores altos de $K_{A S}$ indicam que o lodo acumulado encontra-se pouco digerido, enquanto que para valores pequenos, o lodo está bem digerido. Para lagoas em operação a menos de 1 ano, os valores adotados para $K_{A S}$ podem ser superiores a 1,0 (GONÇALVES 1999). 


\section{METODOLOGIA}

\subsection{Generalidades}

Devido aos possíveis riscos à saúde pública e à vida aquática, a disposição dos lodos de ETA's em cursos de água sem nenhum tratamento tem sido bastante questionada. Com o advento das Leis de Crimes Ambientais, o lançamento do lodo nos leitos dos rios poderá trazer uma série de inconvenientes aos responsáveis pela ETA (Tsutya 2001).

A investigação experimental deste trabalho teve como objetivo principal, avaliar a influência do lançamento do lodo da ETA na ETE do município de São Lourenço da Serra, sendo dividida em duas fases.

$\mathrm{Na}$ primeira fase foram avaliados os parâmetros físico-químicos e bacteriológicos da ETE. Também foram realizadas campanhas batimétricas e calculada a produção de lodo gerado na lagoa anaeróbia sem a interferência dos resíduos da ETA. Posteriomente, na segunda fase, foram efetuados o balanço de massa da ETA e sua produção de lodo, assim como, foram também avaliados os mesmos parâmetros da primeira fase do projeto considerando os efeitos da disposição do lodo na ETE.

\subsection{Caracterização da área de estudo}

A partir da Política Estadual de Recursos Hídricos e do Sistema Integrado de Gerenciamento de Recursos Hídricos, instituída pela Lei Estadual $n^{0} 7.663$, o Estado de São Paulo foi dividido em 22 Unidades de Gerenciamento de Recursos Hídricos (UGRHI's) (CETESB 2004).

A.UGRHI 11- Ribeira do Iguape é constituída por 23 municípios, como mostra a figura 6.1 , os principais rios que constituem a bacia são: 
Juquiá, Ribeira e Ribeira do Iguape e sua área de drenagem é de 16.607 $\mathrm{km}^{2}$ (CETESB 2004).

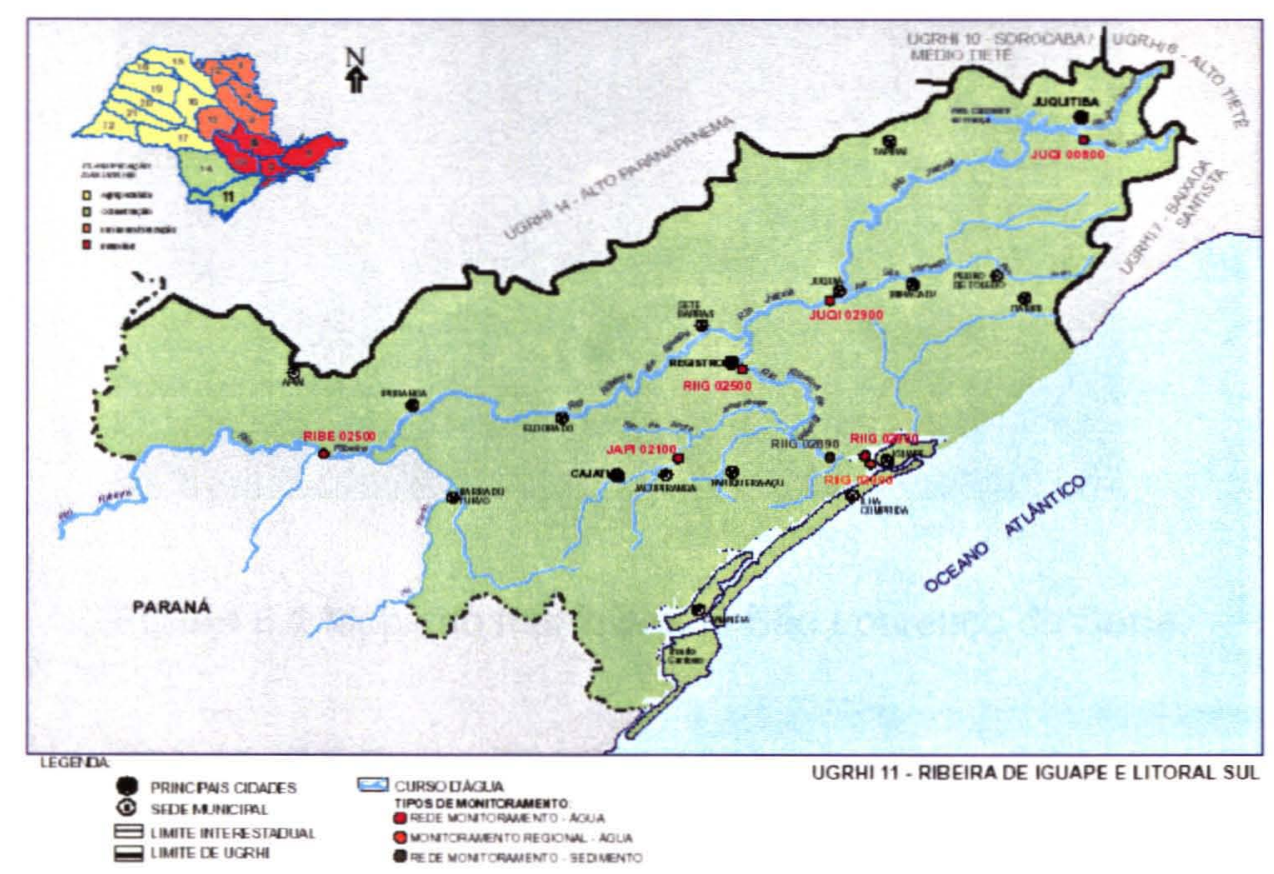

Figura 6.1 Mapa da UGRHI 11- Ribeira do Iguape e Litoral sul.

FONTE: CETESB (2004)

São Lourenço da Serra (figura 6.2), localizado na bacia do Ribeira do Iguape, sul do Estado de São Paulo (Latitude: S $23^{\circ} 51^{\prime} 12.5^{\prime \prime}$ Longitude: $\left.\mathrm{W} 046^{\circ} 56^{\prime} 36.2^{\prime \prime}\right)$, é um dos municípios integrantes da URGHI 11 e, segundo dados do censo 2003 , a cidade conta com uma população total de 12.185 habitantes distribuídos da seguinte maneira: aproximadamente 10.767 habitantes $(88,36 \%)$ concentram-se na área urbana e, 1.418 habitantes $(11,64 \%)$ concentram-se na área rural. As principais atividades econômicas do local são: agricultura, pesca, indústria alimentícia e mineração.

Conforme cadastros da SABESP (2005), o município conta com 2.001 ligações de água e 882 ligações de esgoto, ou seja, apenas $44 \%$ da água distribuída após o seu uso é coletada e encaminhada para o tratamento antes do lançamento no corpo receptor. 


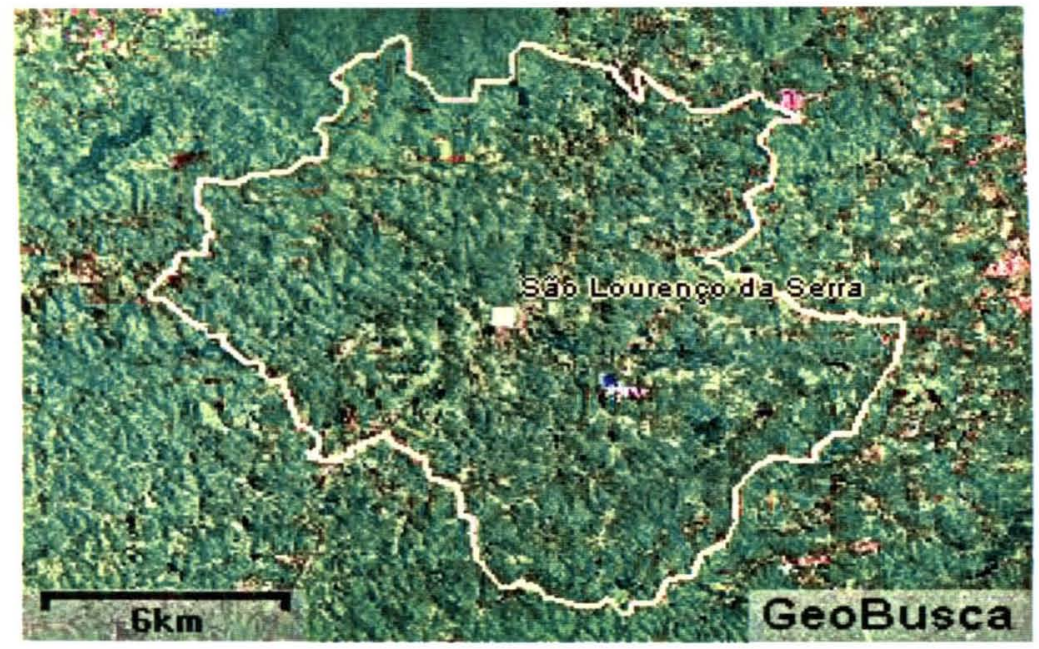

Figura 6.2 Mapa do município de São Lourenço da Serra.

FONTE: GeoBusca (2005)

Uma vez que o município não dispõe de áreas que favoreçam a disposição dos efluentes líquidos no solo por meio de infiltração subsuperficial ou irrigação por aspersão, o efluente então é lançado no Rio São Lourenço. Por se tratar de um rio Classe 1, conforme o artigo 10, da Lei $n^{\circ} 997$, de 31/05/1976, a legislação não permite o lançamento de efluentes em seu corpo receptor.

Em contrapartida, o Decreto $n^{\circ} 43.594$, de $27 / 10 / 98$, inclui no artigo 10 acima mencionado, dispositivo que permite o lançamento desses efluentes, desde que devidamente tratados e observados:

1. os padrões de qualidade estabelecidos para Classe 2;

2. os padrões de emissão;

3. o não comprometimento da qualidade das águas a jusante do lançamento para os usos previstos;

4. a implantação de sistema de desinfecção do efluente final, quando o sistema de tratamento estiver localizado em Área de Proteção e Recuperação de Mananciais. 


\subsection{Descrição da estação de tratamento de água.}

A água bruta que abastece a ETA de São Lourenço da Serra é proveniente do Rio São Lourenço, localizado a poucos metros da estação. O sistema de tratamento de água utiliza como coagulante o sulfato de alumínio [ $\left.\left.\mathrm{Al}_{2}\left(\mathrm{SO}_{4}\right)_{3}\right) \cdot 14 \mathrm{H}_{2} \mathrm{O}\right]$ e é constituído por: floculador (36 células), 02 decantadores (com módulos tubulares) e 04 filtros, conforme figuras 6.3 a 6.8 .

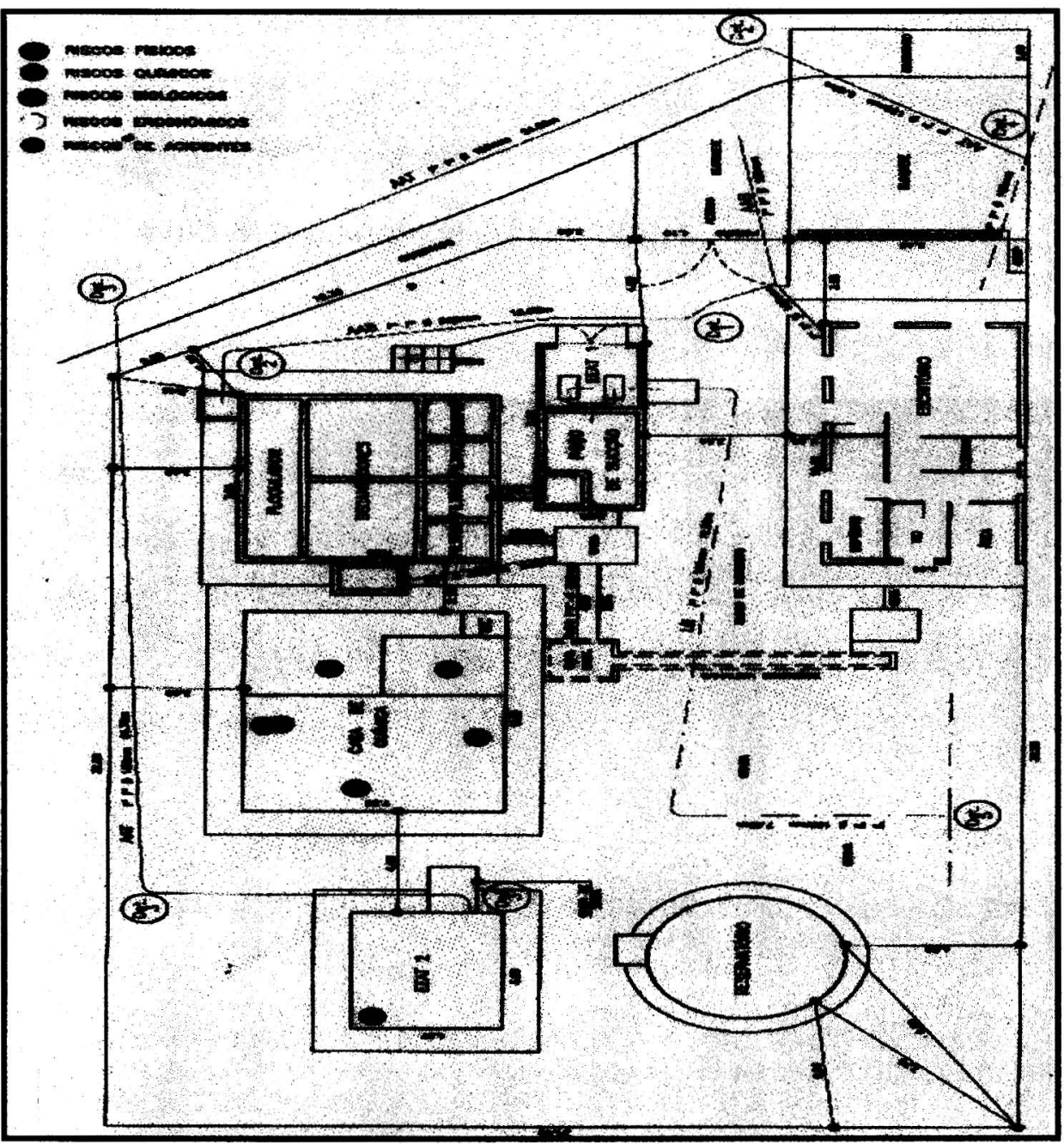

Figura 6.3 Esquema da ETA São Lourenço da Serra.

FONTE: SABESP (2004) 


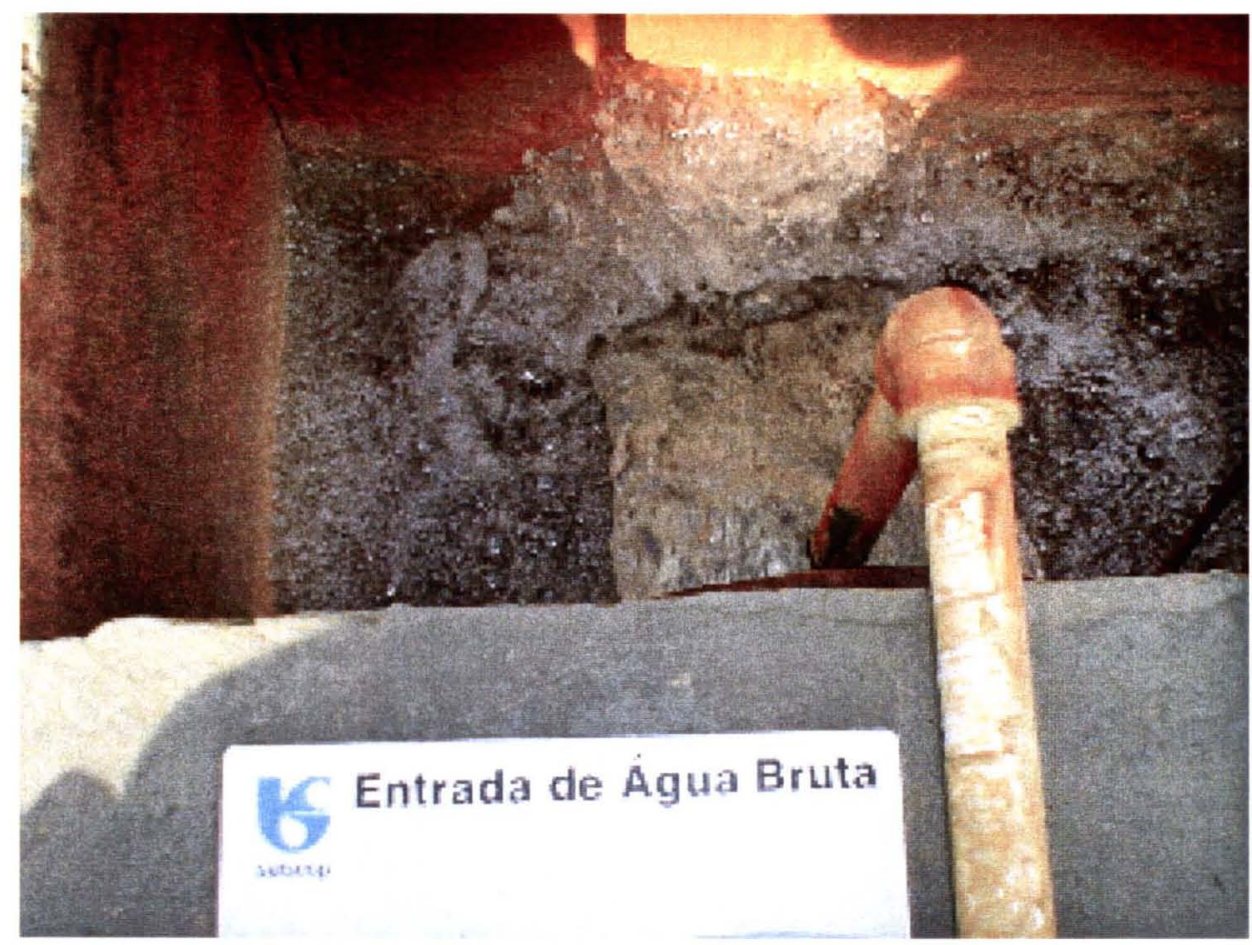

Figura 6.4 Entrada de água bruta.

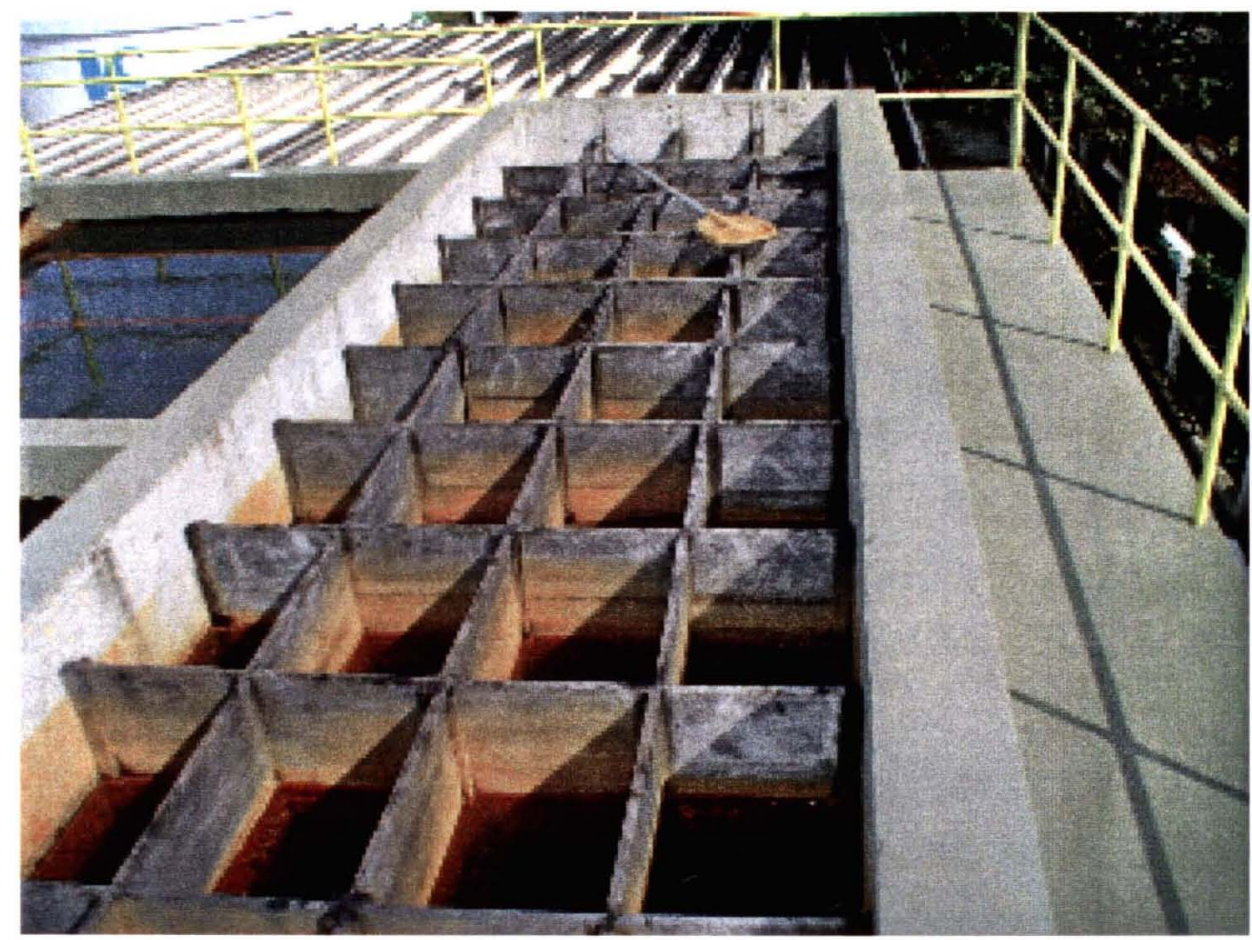

Figura 6.5 Tanque de coagulação e floculação. 


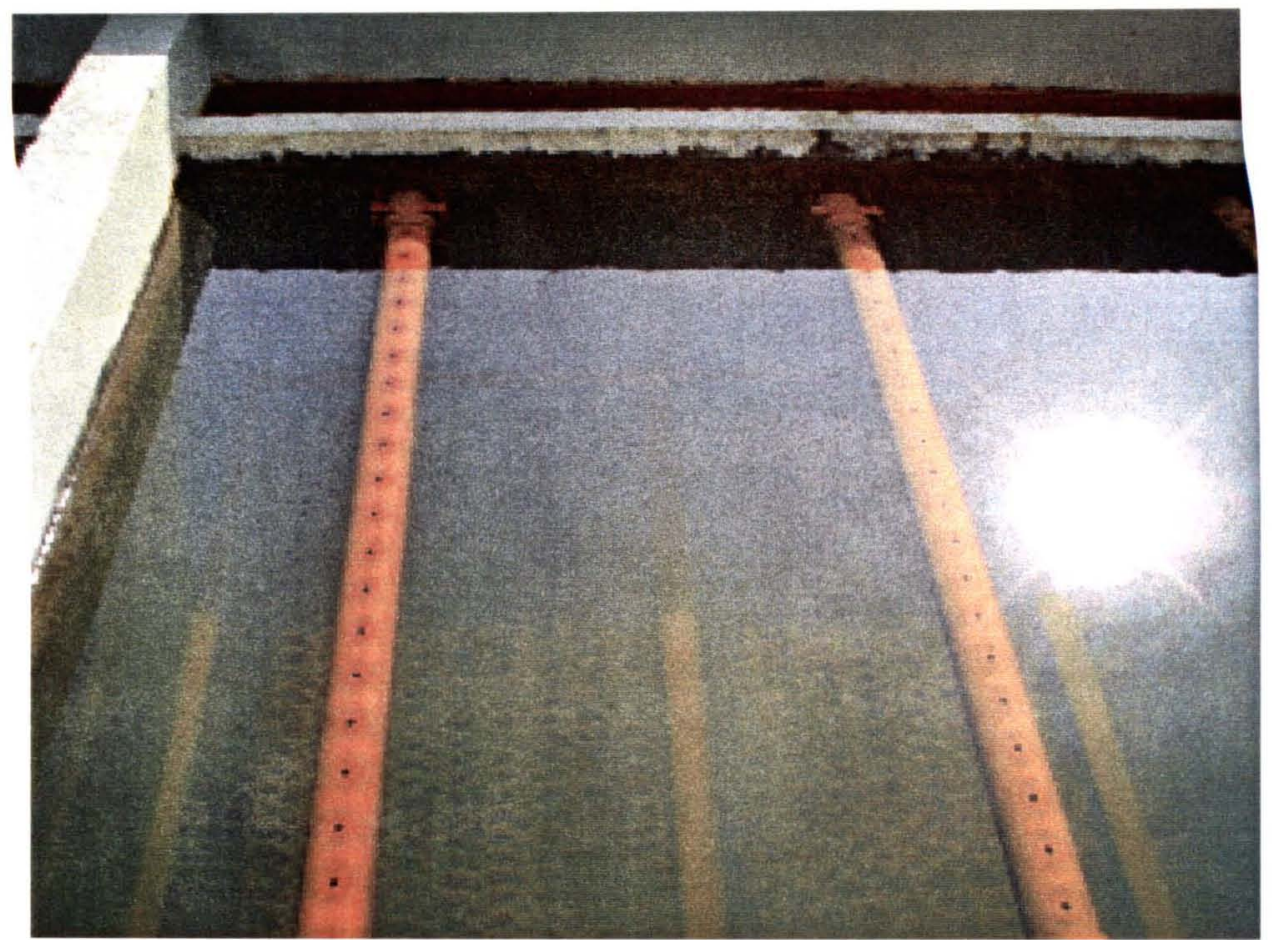

Figura 6.6 Tanque de decantação.

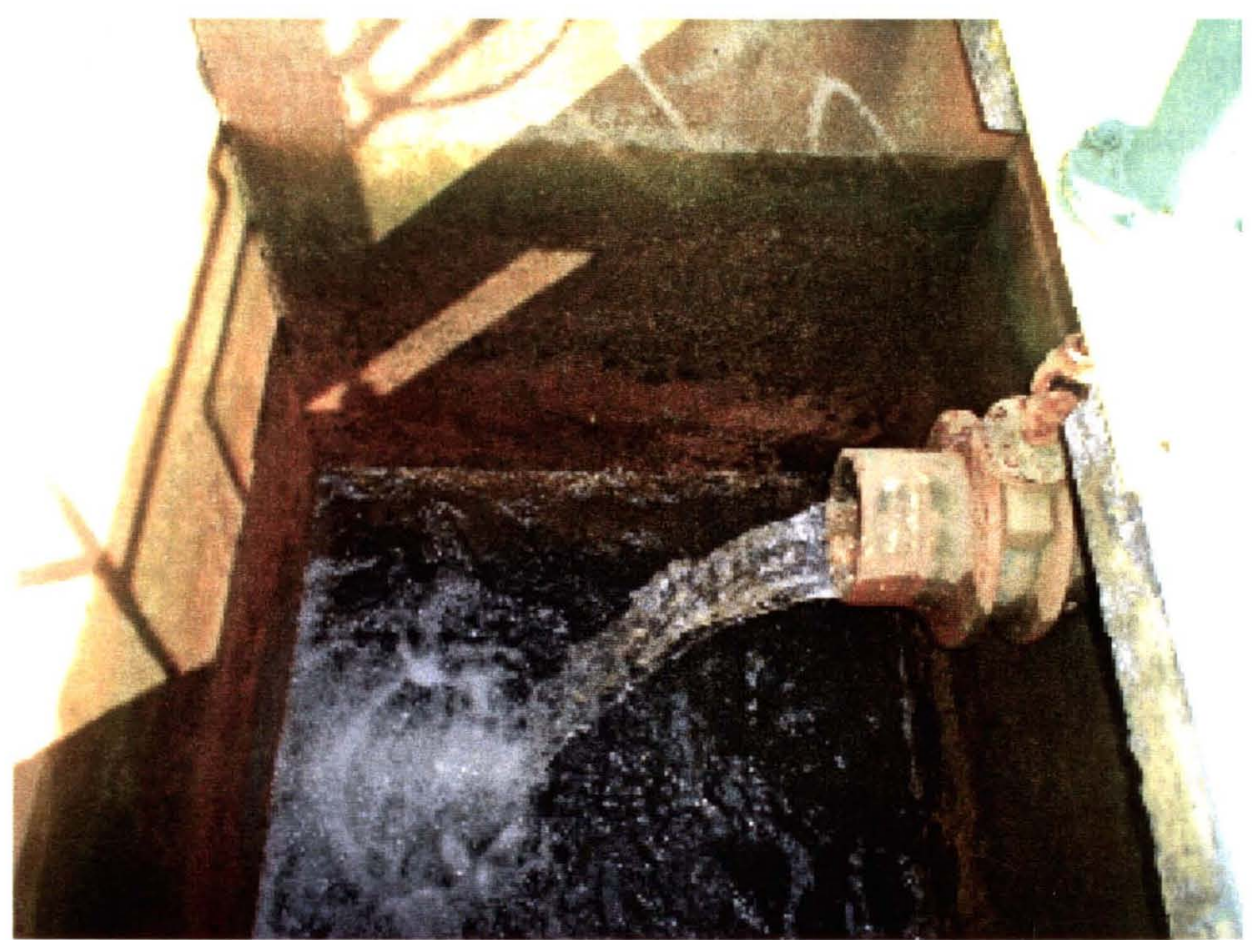

Figura 6.7 Filtros descendentes. 


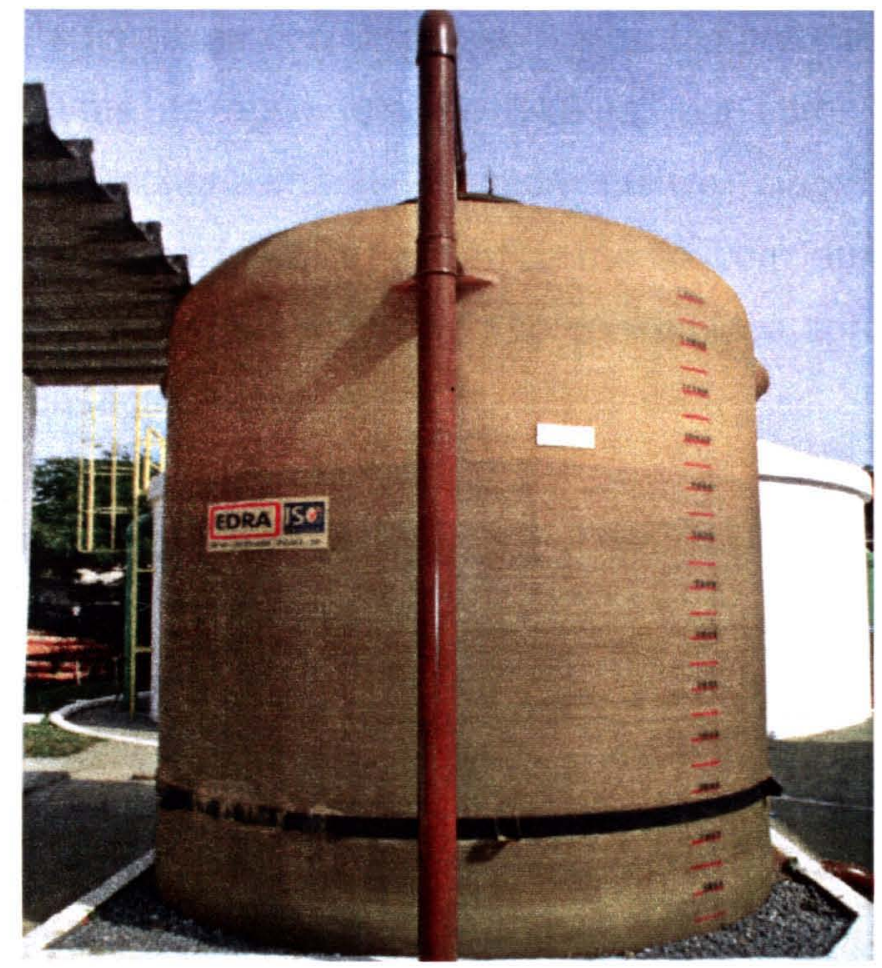

Figura 6.8 Tanque de equalização.

Em 2004, segundo boletins de operação da ETA (Anexo A SABESP), a vazão média mensal de água tratada foi de $34.207 \mathrm{~m}^{3} / \mathrm{mês}$ $\left(1.123,05 \mathrm{~m}^{3} / \mathrm{d}\right)$, sendo $1.390 \mathrm{~m}^{3} /$ mês utilizados no processo de lavagem dos filtros e, $400 \mathrm{~m}^{3} /$ mês empregados para lavagem dos decantadores, representando respectivamente $4,06 \%$ e $1,17 \%$ do volume total aduzido, conforme (figura 6.9).

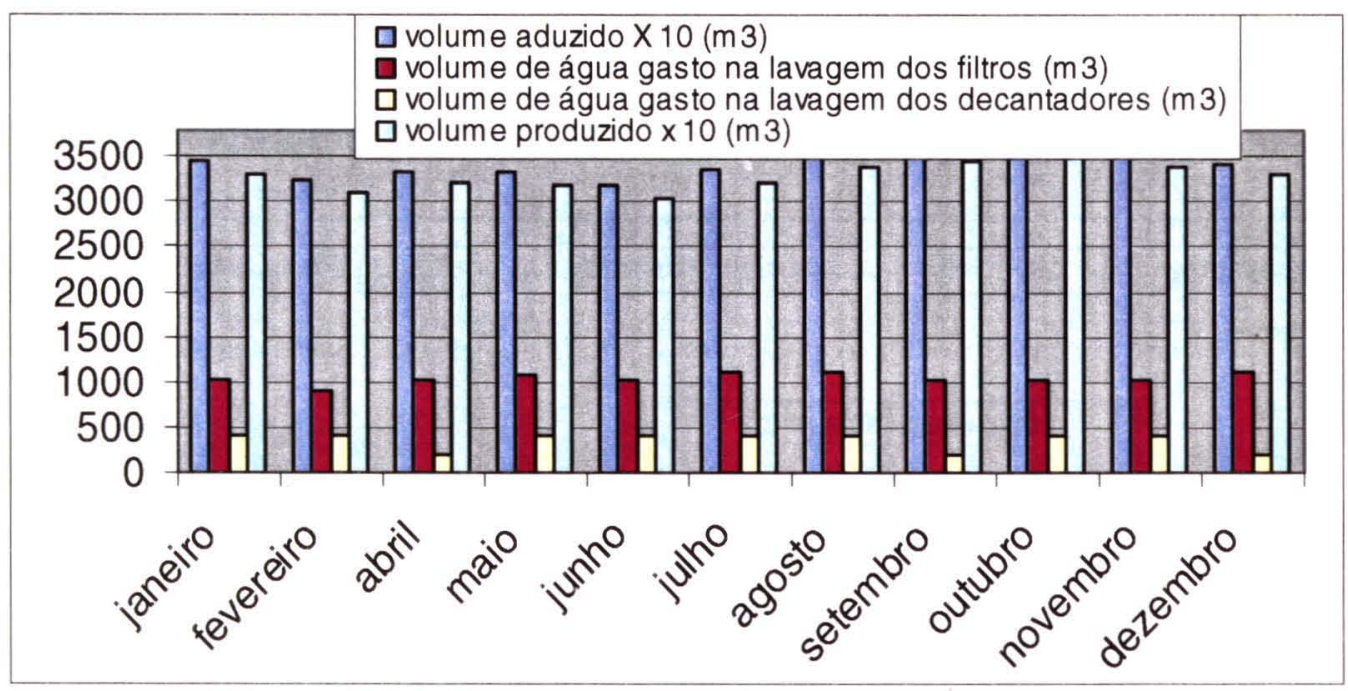

Figura 6.9 Volume de água tratada na ETA, utilizado nas lavagens dos filtros e limpeza dos decantadores. 
As limpezas dos filtros são realizadas em dias alternados utilizando um volume de água total de $34,5 \mathrm{~m}^{3}$ por filtro. Os decantadores são limpos simultaneamente a cada quinze dias, através de registros localizados no fundo e, superficialmente com auxílio de mangueira de pressão. Neste procedimento são consumidos aproximadamente $200 \mathrm{~m}^{3}$ de água (figura 6.10).

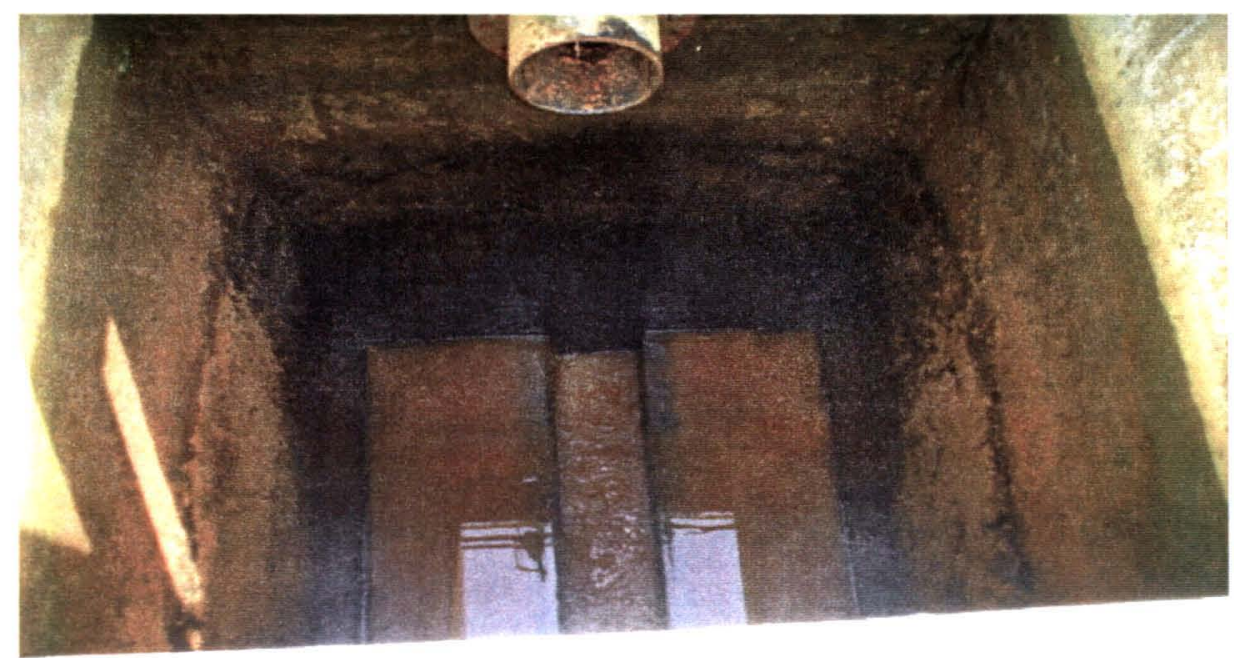

Figura 6.10 Limpeza dos filtros.

Todo resíduo gerado, assim como, as águas utilizadas no processo de lavagem dos filtros e decantadores são encaminhadas para um tanque de equalização (figura 6.8) de aproximadamente 13.000 litros, sendo então transferidos posteriormente para a rede coletora de esgoto e encaminhados a ETE (figuras 6.11).

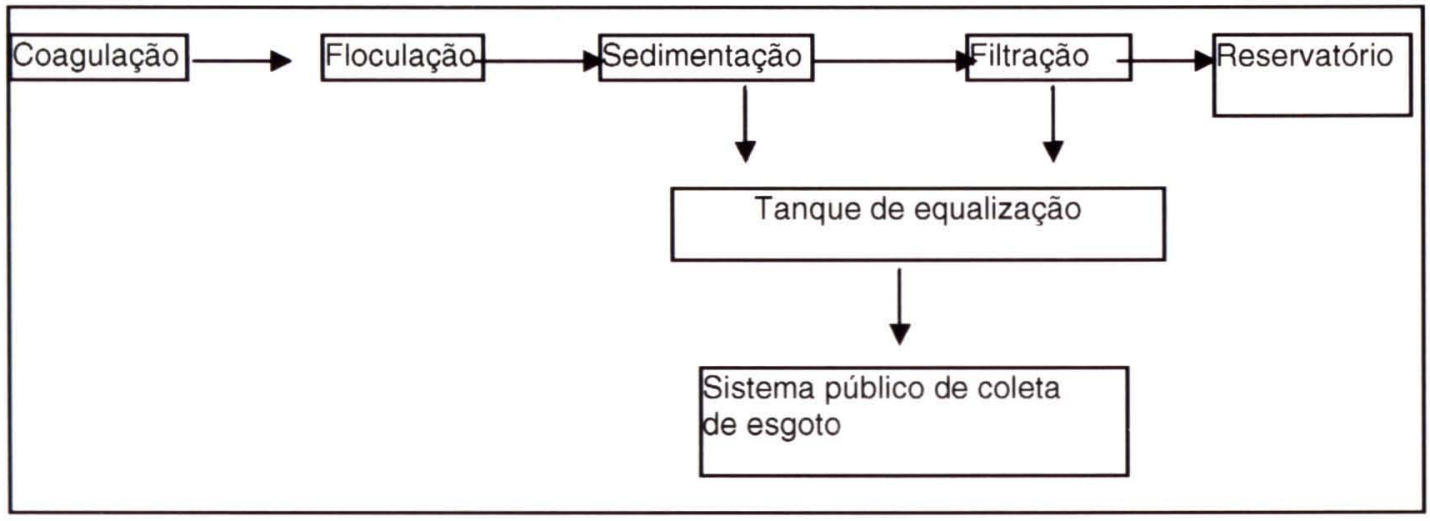

Figura 6.11 Concepção do sistema de tratamento da fase sólida gerada na ETA. 


\subsection{Descrição da estação de tratamento de esgoto.}

A estação de tratamento de esgoto de São Lourenço da Serra foi projetada para tratar os esgotos sanitários da sede do município de São Lourenço da Serra e do Distrito de Despézio.

O sistema foi inaugurado em 22 de fevereiro de 2001 e entrou em operação em outubro do mesmo ano, localiza-se a jusante da cidade em uma área de cerca de 18,5 ha, entre a estrada dos Carolinos e o rio São Lourenço. Os esgotos sanitários são encaminhados a ETE através de bombeamento das estações elevatórias de esgotos das redes coletoras de São Lourenço e do distrito de Despézio.

As principais características do sistema de esgotos sanitários de São Lourenço da Serra e Despézio são apresentadas a seguir conforme quadros 6.1 e 6.2 .

Quadro 6.1 Características do sistema de esgoto sanitário.

\begin{tabular}{c|c|c|c}
\hline Descrição & Unidades & São Lourenço & Despézio \\
\hline Número de domicílios & unidades & 1.491 & 174 \\
\hline $\begin{array}{c}\text { Taxa de crescimento } \\
\text { populacional }\end{array}$ & $\%$ a.a & 1,8 & 1,83 \\
\hline $\begin{array}{c}\text { Indice de habitantes por } \\
\text { domicílio }\end{array}$ & hab/domic. & 3,8 & 3,8 \\
\hline $\begin{array}{c}\text { Extensão de redes coletoras } \\
\begin{array}{c}\text { Estação elevatória de esgoto } \\
\text { e linhas de recalque }\end{array}\end{array}$ & unidades & 12.874 & 1.860 \\
\hline
\end{tabular}

FONTE: SABESP (1998) 
Quadro 6.2 Características das estações elevatórias de esgoto sanitário.

\begin{tabular}{c|c|c|c|c|c}
\hline Local & EEE & $\begin{array}{c}\text { Vazão } \\
\text { EEE } \\
(\mathbf{l} / \mathbf{s})\end{array}$ & $\begin{array}{c}\text { Altura } \\
\text { manométrica } \\
(\mathbf{m} . \mathbf{c . a})\end{array}$ & $\begin{array}{c}\text { Linha de } \\
\text { recalque } \\
(\phi \mathbf{~ m m})\end{array}$ & $\begin{array}{c}\text { Extensão } \\
(\mathbf{m})\end{array}$ \\
\hline São Lourenço & $\mathrm{A} 1$ & 19 & 5,83 & 150 & 130 \\
\hline \multirow{3}{*}{ Despézio } & 1 & 1,4 & 32,1 & 75 & 530 \\
\cline { 2 - 6 } & 2 & 1,0 & 32,0 & 75 & 294 \\
\cline { 2 - 6 } & 3 & 3,6 & 71,0 & 100 & 3.544 \\
\hline
\end{tabular}

FONTE: SABESP (1998)

No dimensionamento da estação foram utilizados os seguintes parâmetros e critérios de projeto, assim como, estimativa de populações, vazões e carga orgânica, apresentados no quadro 6.3.

Quadro 6.3 Parâmetros de projeto utilizados no dimensionamento.

\begin{tabular}{c|c|c|c|c}
\hline & & 1997 & 2007 & 2017 \\
\hline Taxa de consumo de água "per capita" & $150 / / h a b . d ~$ & & & \\
\hline Coeficiente de retorno & 0,80 & & & \\
\hline Coeficiente de vazão máxima diária (K1) & 1,2 & & & \\
\hline Coeficiente de vazão máxima horária (K2) & 1,5 & & & \\
\hline $\begin{array}{c}\text { Taxa de contribuição de infiltração para } \\
\text { rede coletora }\end{array}$ & $0,15 / / h a b . d$ & & & \\
\hline $\begin{array}{c}\text { Taxa de contribuição de infiltração para } \\
\text { coletor tronco }\end{array}$ & $0,50 / /$ hab.d & & & \\
\hline Carga orgânica "per capita" & $54 g /$ hab.d & & & \\
\hline População - habitantes & & 4353 & 5219 & 6269 \\
\hline Vazão média total (//s) & & 7,98 & 9,18 & 11,09 \\
\hline Carga orgânica - kg.DBO/dia & & 235 & 282 & 339 \\
\hline
\end{tabular}

FONTE: SABESP (1998) 


\subsubsection{Processo de tratamento}

O processo de tratamento resume-se em tratamento preliminar (grades médias, 2 caixas de areia com 4,50m $\times 0,35 \mathrm{~m}$ cada uma e calha Parshall $W=3^{n}$ ) seguido por tratamento através de lagoa anaeróbia seguida de lagoa facultativa, comumente denominado Sistema Australiano. No final do processo, antes do lançamento no corpo receptor, o efluente é conduzido a um tanque de cloração para desinfecção $\theta$, os resíduos gerados nas caixas de desarenação são condicionados em valas impermeabilizadas. A figura 6.12 apresenta um esquema em planta da estação de tratamento, enquanto que, as características físicas das lagoas e a eficiência da estação são apresentadas nos quadros 6.4 e 6.5.

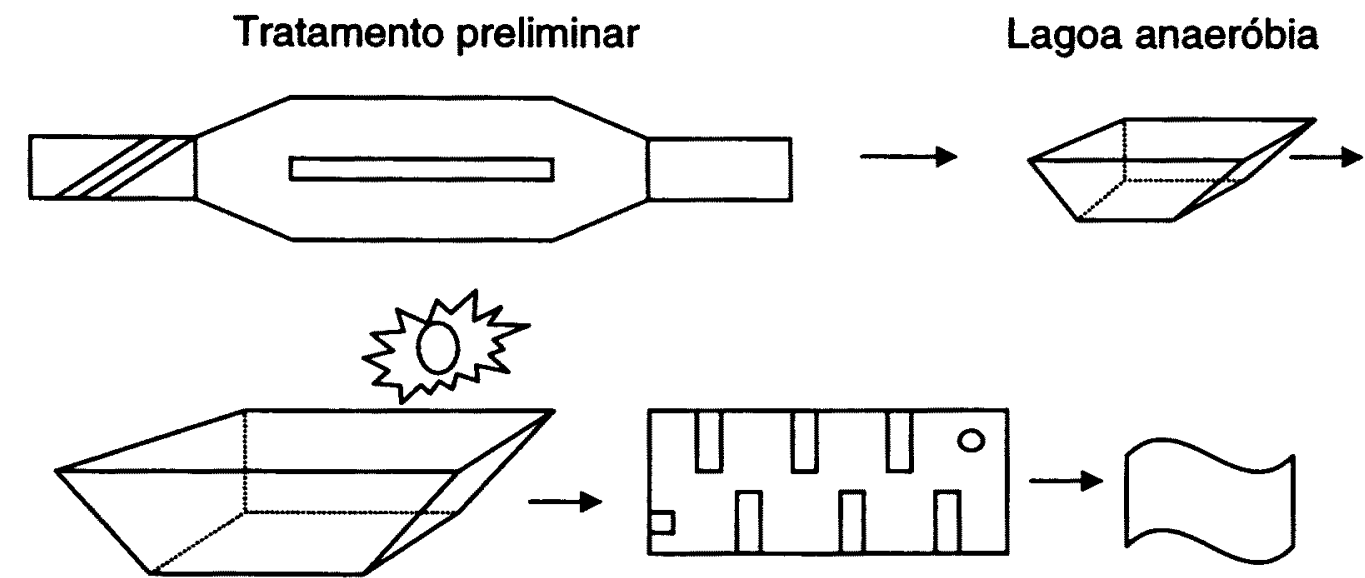

Lagoa facultativa

Tanque de cloro

Corpo receptor

Figura 6.12 - Esquema llustrativo da Estação de Tratamento de Esgoto.

No processo adotado, durante a fase de dimensionamento, foram estimadas as seguintes remoções de cargas:

$>$ Eficiência na remoção de DBO (70-90\%)

$>$ Eficiência na remoção de nitrogênio $(N)$ (30-50\%)

$>$ Eficiência na remoção de fósforo $(P)(20-60 \%)$

$>$ Eficiência na remoção de coliformes (20-60\%) 
Quadro 6.4 Dados de projeto das características físicas das lagoas anaeróbia $\Theta$ facultativa.

\begin{tabular}{l|c|c}
\hline \multirow{2}{*}{ Características } & \multicolumn{2}{|c}{ Lagoas } \\
\cline { 2 - 3 } & Anaeróbia & Facultativa \\
\hline Número de lagoas (unidades) & 1 & 1 \\
\hline Eficiência de redução (\%) & 50 & 80 \\
\hline Vazão média (Vs - m/d) & $12-1037$ & $12-1037$ \\
\hline DBO afluente (kgDBO/dia) & 339 & 169,5 \\
\hline Concentração afluente (mg/L) & 327 & 160 \\
\hline Tempo de detenção (dias) & 5 & 18,5 \\
\hline Largura (fundo - útil - superfície) (m) & $22,5-36,5-38,5$ & $56-64-66$ \\
\hline Comprimento (fundo - útil - superfície) (m) & $42-56-58$ & $152-160-162$ \\
\hline Profundidade (útil - total) & $3,50-4,00$ & $2,0-2,50$ \\
\hline Borda livre (m) & 0,50 & 0,50 \\
\hline Volume útil (m ${ }^{3}$ ) & 5.200 & 18.725 \\
\hline
\end{tabular}

FONTE: SABESP (1998)

Quadro 6.5 Dados de projeto da eficiência total da ETE.

\begin{tabular}{l|c}
\hline Características & Parâmetros \\
\hline Tempo de detenção (dias) & 5 \\
\hline Lagoa anaeróbia & 18,5 \\
\hline Lagoa facultativa & 23,5 \\
\hline Tempo de detenção total (dias) & 339 \\
\hline DBO afluente (kgDBO/dia) & 327 \\
\hline Concentração afluente (mg/L) & 33,9 \\
\hline DBO efluente (kgDBO/dia) & 32,7 \\
\hline Concentração efluente (mg/L) & 305,1 \\
\hline DBO removida (kgDBO/dia) & 90 \\
\hline Eficiência na remoção do sistema(\%) & 19 \\
\hline Vazão máxima (Vs) &
\end{tabular}




\subsection{Pontos de amostragem e coleta das amostras}

Para a avaliação do sistema e caracterização das águas residuárias, as coletas das amostras do esgoto bruto e dos efluentes das lagoas anaeróbia e facultativa foram feitas quinzenalmente na fase $1 \mathrm{e}$ semanalmente na fase 2 , todas na parte da manhã.

Para a coleta foram utilizados: balde, corda e frascos de $1000 \mathrm{ml}$, conforme figura abaixo. Para posterior análise, depois de identificados, os frascos foram armazenados e transportados em caixas de isopor até os laboratórios da FSP/USP sob refrigeração de $4{ }^{\circ} \mathrm{C}$.

Nos pontos de amostragens também foram medidos os parâmetros: temperatura e $\mathrm{pH}$ do líquido da lagoa e, foi verificada também a temperatura do ar.

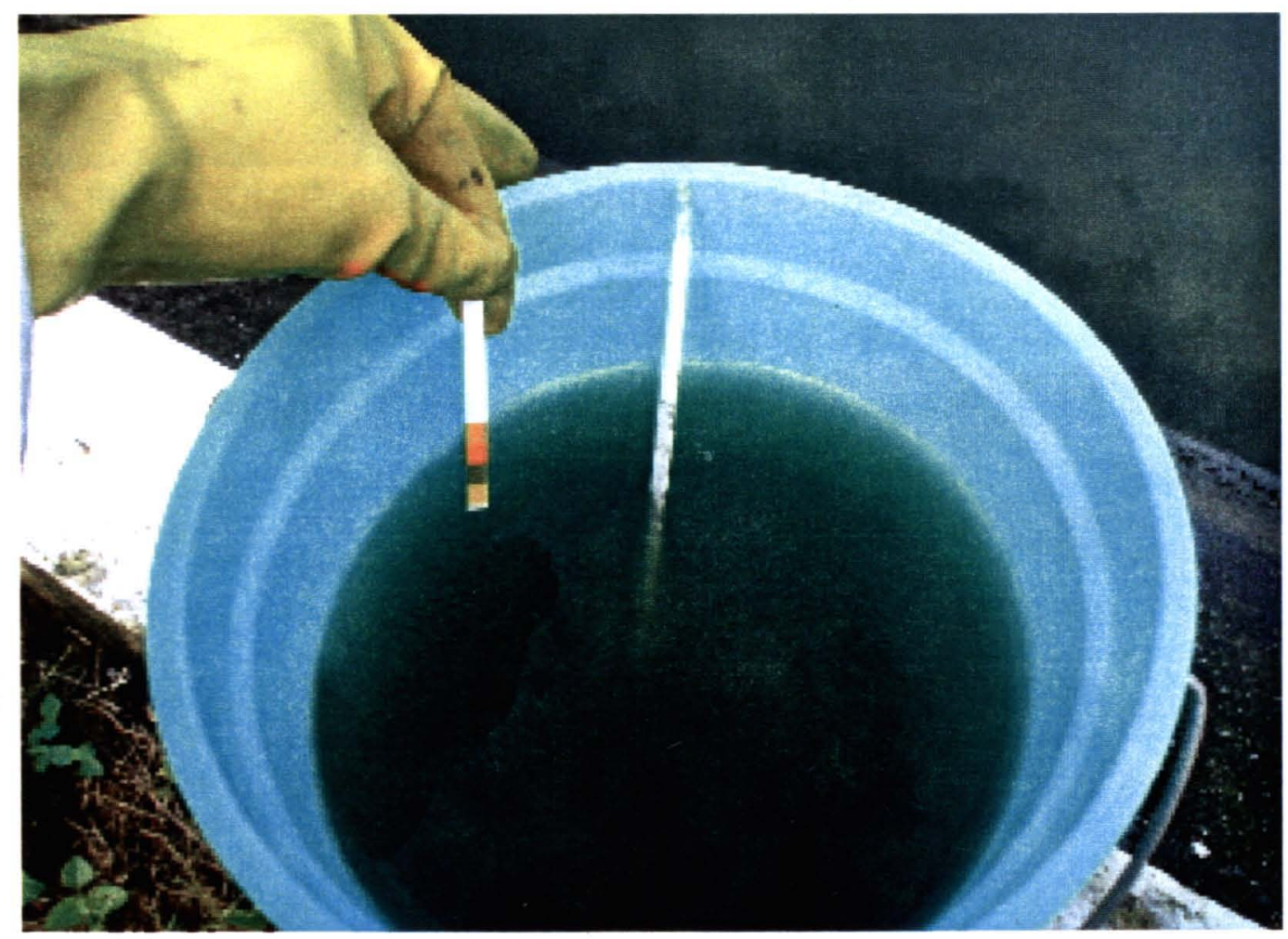

Figura 6.13 Coleta de esgoto utilizando balde e corda 
No ponto 1, com o objetivo de garantir uma boa homogeneização da amostra, a coleta foi feita no centro do canal, onde se verificam maiores velocidades de escoamento (ponto de regime turbulento). Nos pontos 2 e 3 , as coletas ocorreram na entrada e saída da lagoa facultativa.

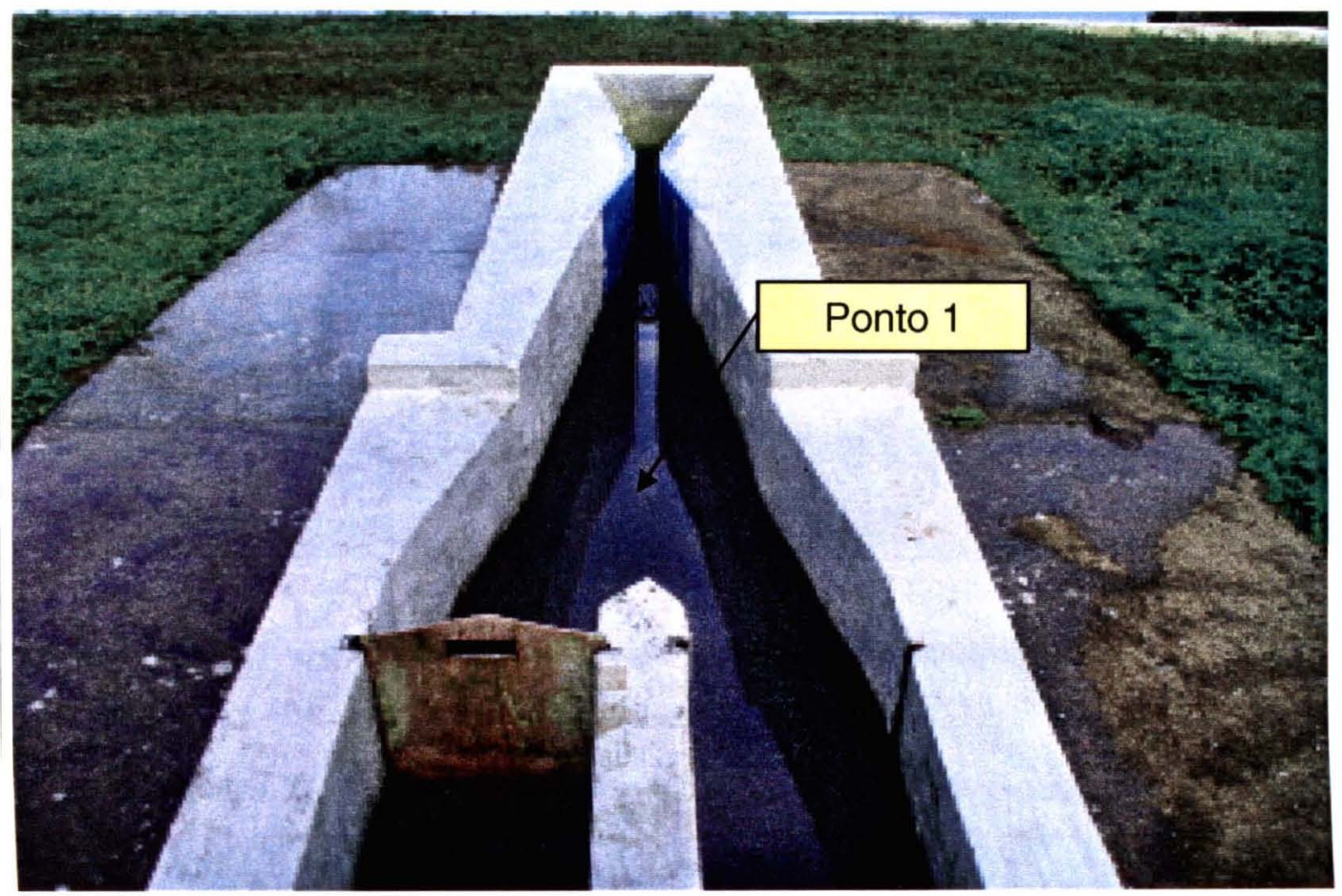

Figura 6.14 Ponto de coleta $n^{\circ} 1$ ( pós caixa de areia).

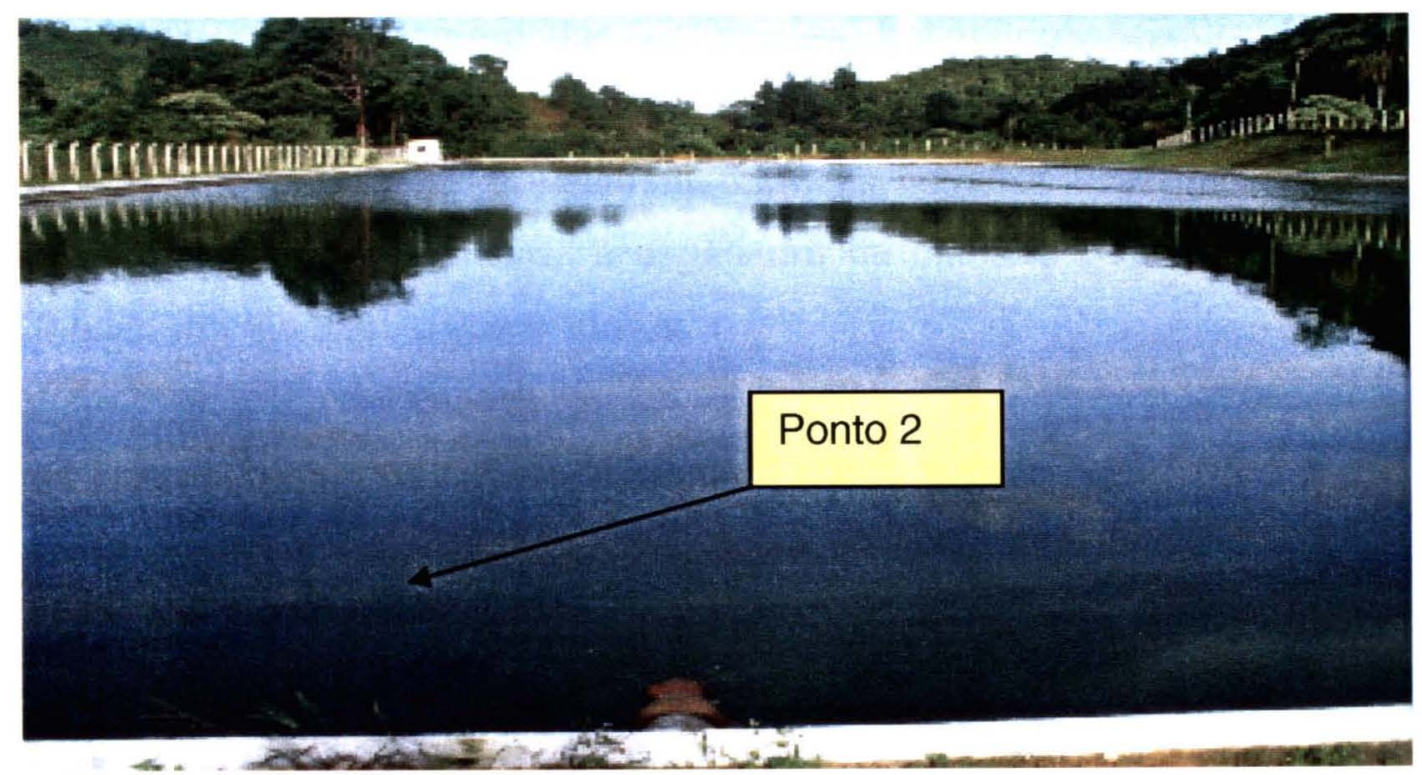

Figura 6.15 Ponto de coleta $\mathrm{n}^{\circ} 2$ (entrada da lagoa facultativa). 

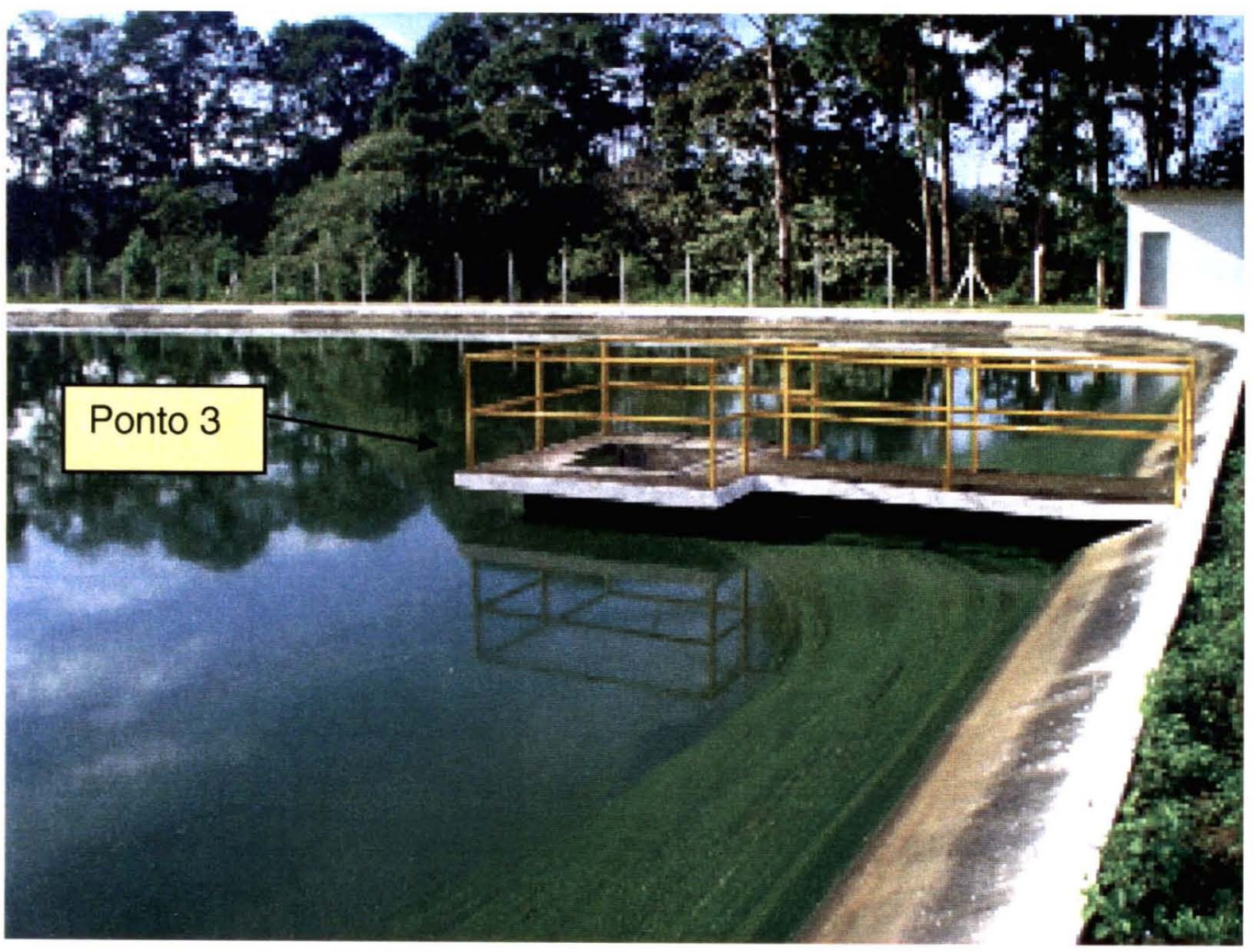

Figura 6.16 Ponto de coleta $\mathrm{n}^{\circ} 3$ (saída da lagoa facultativa).

\subsection{Seções e campanhas batimétricas para determinação da espessura da camada de lodo}

Utilizando-se um total de 12 piquetes chumbados na borda da lagoa anaeróbia, foram demarcadas as seções batimétricas (figura 6.17). Cordas foram esticadas de um lado a outro de cada divisão e do ponto de encontro das linhas transversais com as linhas longitudinais foram retiradas amostras e medida a espessura da camada de lodo, situada imediatamente abaixo dos mesmos.

As seções foram percorridas com barco e para determinação da altura de camada de lodo foram utilizados 03 tubos de PVC de diâmetro de 1" com 1,50 m de comprimento cada, toalhas brancas envolvidas no tubo e trena metálica de $5,0 \mathrm{~m}$. Para coleta do lodo foi empregado tubo translúcido de 1" (figuras 6.18 a 6.20). 

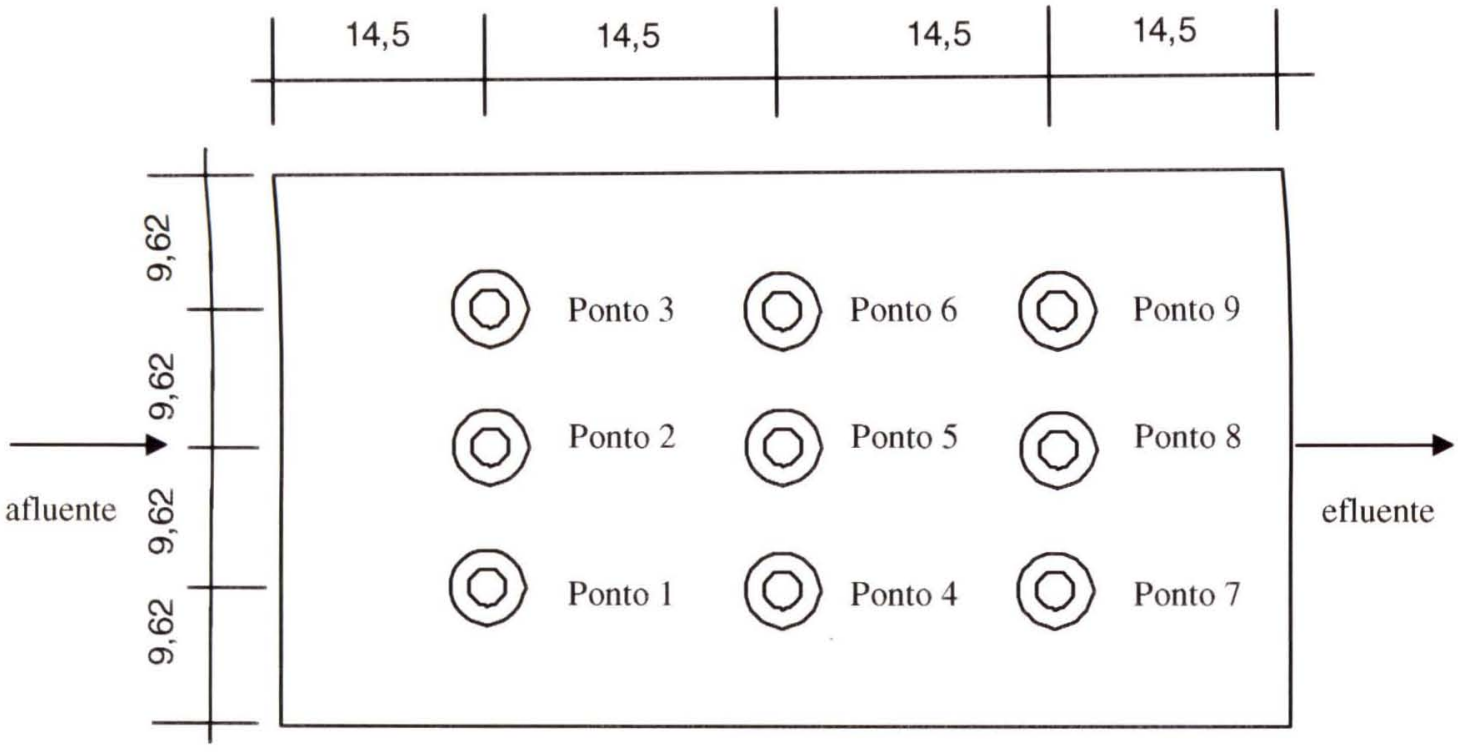

Figura 6.17 Pontos de amostragem do lodo e seções batimétricas na lagoa anaeróbia.

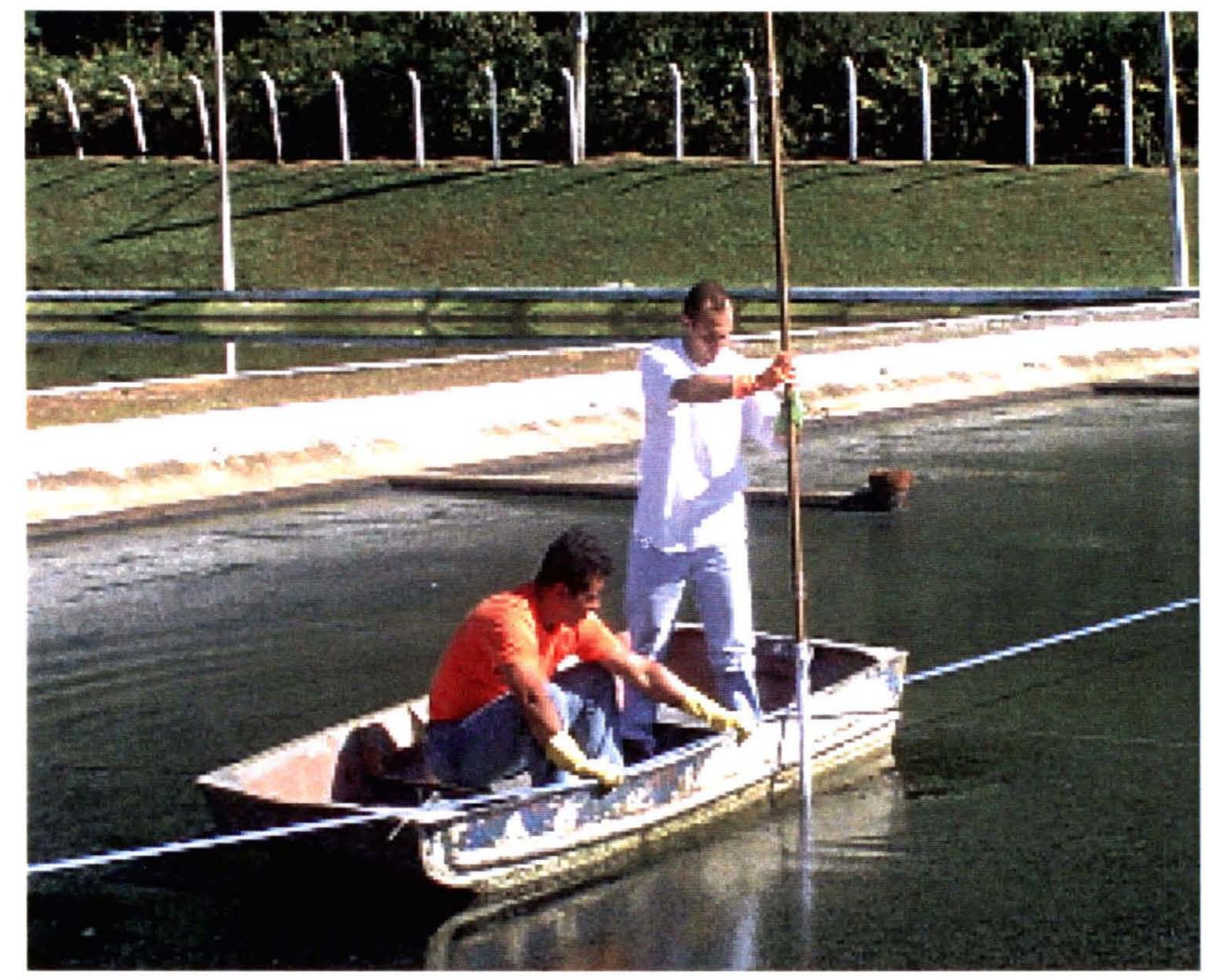

Figura 6.18 Ponto de amostragem da espessura do lodo. 


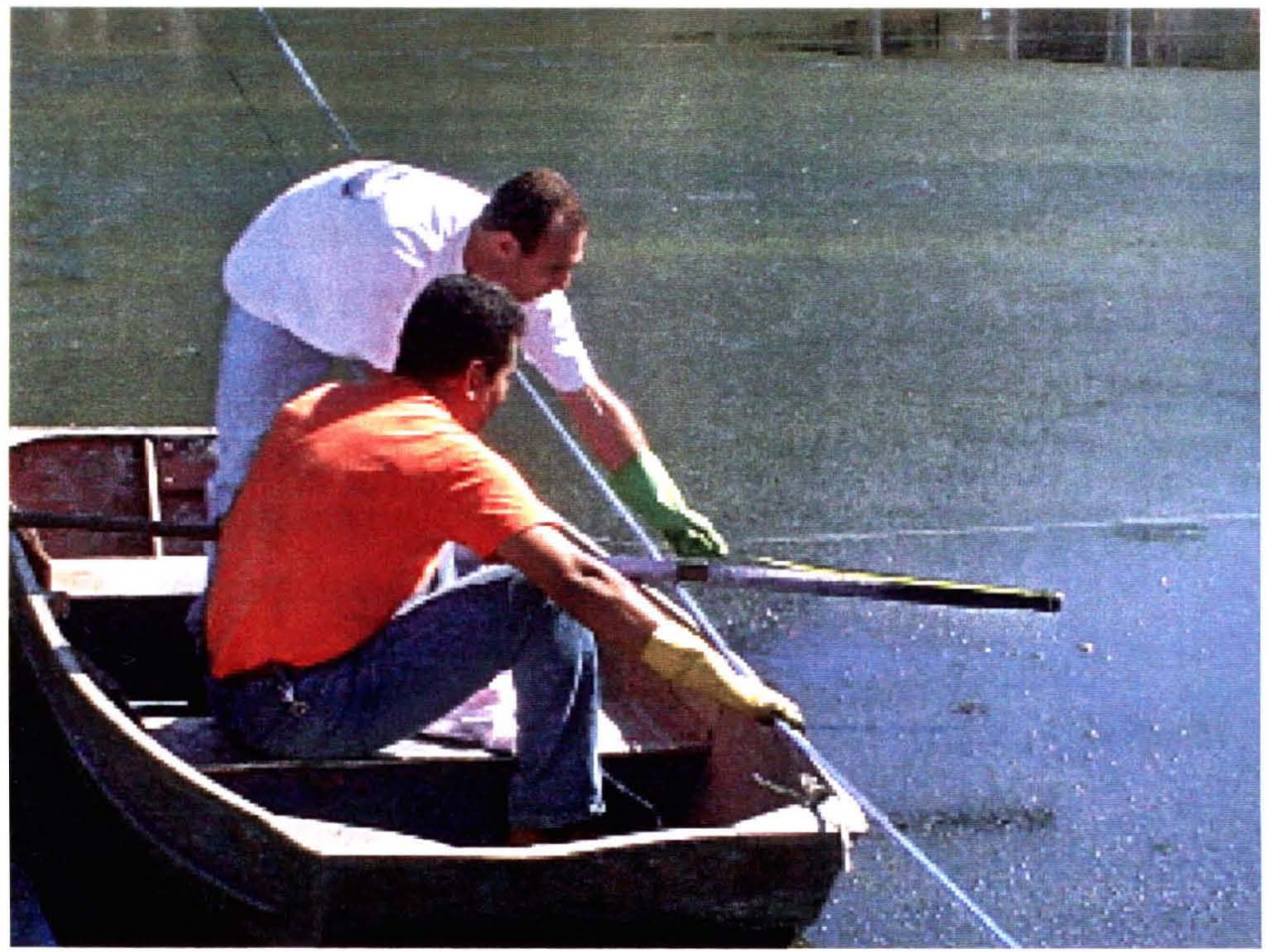

Figura 6.19 Medição da espessura da camada de lodo.

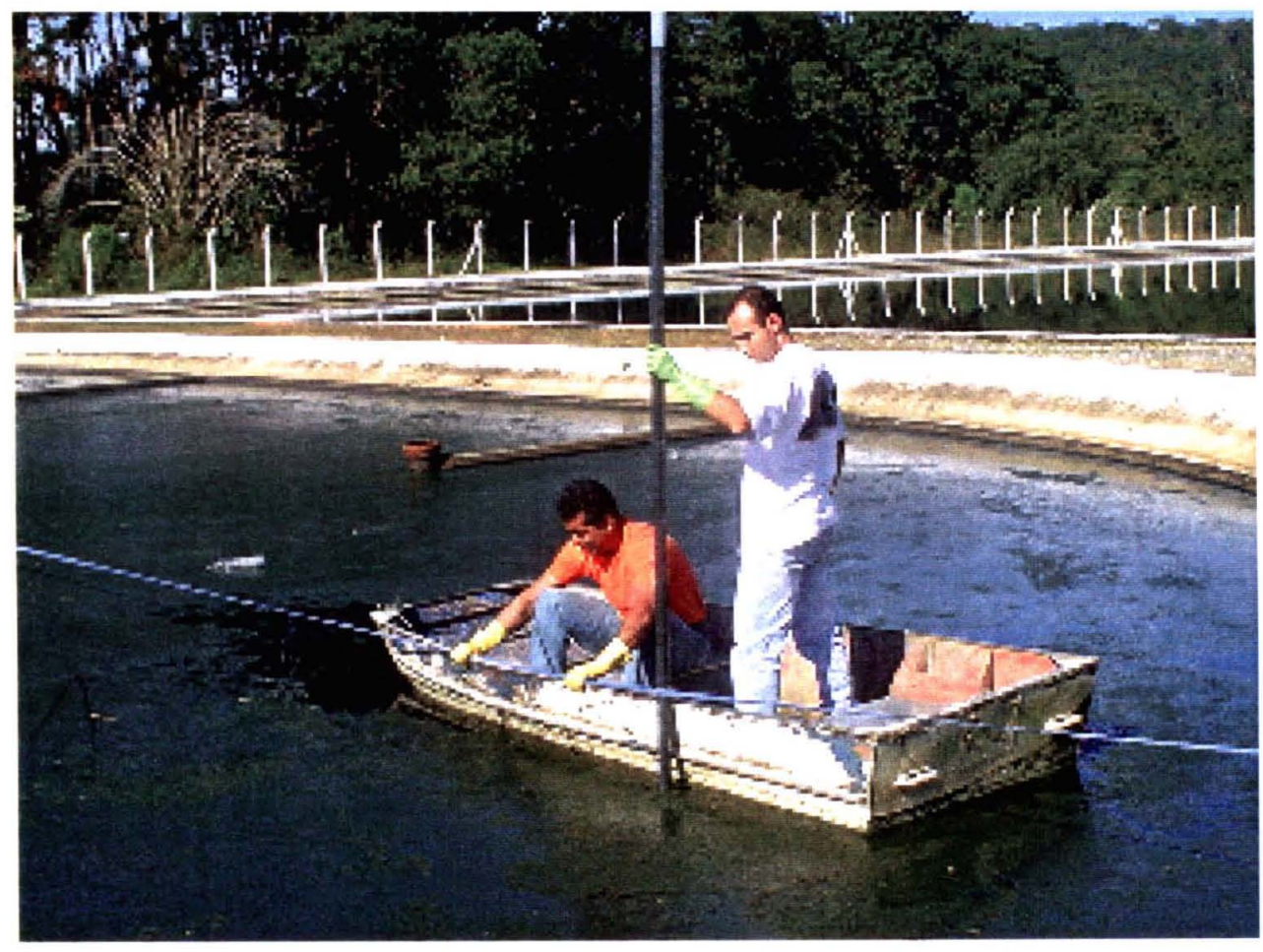

Figura 6.20 Retirada de amostra de lodo. 


\subsection{Análises e exames laboratoriais}

As análises das amostras foram realizadas nos laboratórios da FSP/USP, segundo recomendações do "Standard Methods for the Examination of Water and Wastewater "(APHA, 1998).

Os métodos empregados e equipamentos utilizados para determinação das características físico-químicas e bacteriológicas estão apresentados nos quadros 6.6 e 6.7 .

Quadro 6.6 - Características Físico-químicas e bacteriológicas avaliadas nos Pontos de Amostragem e Metodologia Analítica.

\begin{tabular}{|c|c|}
\hline Características & Metodologia Analítica \\
\hline $\mathrm{DBO}_{5,20}$ & Método de incubação a $20^{\circ} \mathrm{C}$ por 5 dias \\
\hline DBO $_{5,20}$ filtrada & $\begin{array}{l}\text { Uso de filtro milipore AP40 seguidode incubação à } 20^{\circ} \mathrm{C} \\
\text { por } 5 \text { dias }\end{array}$ \\
\hline DQO & Método de digestão por dicromato de potássio \\
\hline DQO filtrada & $\begin{array}{l}\text { Uso de filtro milipore AP40 seguido de digestão por } \\
\text { dicromato de potássio }\end{array}$ \\
\hline Nitrogênio Total Kjedhal & $\begin{array}{c}\text { Colorimetria automática por salicilato de sódio após } \\
\text { digestão ácida em meio sulfúrico }\end{array}$ \\
\hline Nitrogênio amoniacal & Colorimetria automática por salicilato de sódio \\
\hline Fósforo Total & $\begin{array}{l}\text { Método espectofotométrico da reação com molibidato de } \\
\text { amônio e ácido ascórbico após digestão com persulfato } \\
\text { de potássio }\end{array}$ \\
\hline Ortofosfato & $\begin{array}{l}\text { Método espectofotométrico da reação com molibidato de } \\
\text { amônio e ácido ascórbico }\end{array}$ \\
\hline Série de sólidos & Método gravimétrico \\
\hline pH (campo) & Fita universal \\
\hline Temperatura (campo) & Termômetro de mercúrio (Graus Celsius) \\
\hline $\begin{array}{l}\text { Coliformes totais e } \\
\text { coliformes termotolerantes }\end{array}$ & Método de determinação através de tubos múltiplos. \\
\hline
\end{tabular}


Quadro 6.7 - Equipamentos utilizados na determinação das Características Físico-químicas e bacteriológicas avaliadas nos Pontos de Amostragem.

\begin{tabular}{|l|c|}
\hline \multicolumn{1}{|c|}{ Características } & Equipamentos \\
\hline DBO $_{5,20}$ & Incubadora DBO (Quimis BRAND) \\
\hline DBO $_{5,20}$ filtrada & Incubadora DBO (Quimis BRAND) \\
\hline DQO & Digestor (HACH) \\
\hline DQO filtrada & Digestor (HACH) \\
\hline Nitrogênio Total Kjedhal & Destilador (Marconi) \\
\hline Nitrogênio amoniacal & Destilador (Marconi) \\
\hline Fósforo Total & Espectofotômetro (HACH) \\
\hline Ortofosfato & Espectofotômetro (HACH) \\
\hline Série de sólidos & Estufa , múlla e cone plástico \\
\hline
\end{tabular}




\section{DISCUSSÃO DOS RESULTADOS}

Os resultados obtidos são apresentados $\theta$ discutidos em duas fases, sendo a primeira, pertinente aos resultados dos parâmetros físico químicos e bacteriológicos realizados em três pontos da ETE, indicados nas figuras 6.13 a 6.15. A segunda fase, referente aos mesmos parâmetros observados na fase 1 , levando em consideração 0 lançamento do lodo da ETA na ETE

\subsection{Padrões de lançamento de efluentes}

Os corpos receptores são classificados em função de seus usos preponderantes, sendo estabelecidos padrões de qualidade a serem obedecidos através das legislações federal e estadual. No Brasil, a maioria dos rios são classificados como classe $2 \mathrm{e}$, para o lançamento de efluentes de qualquer fonte poluidora nesses corpos receptores, foram estabelecidos e impostos padrões que garantam qualidade mínima a ser atendida por esses despejos.

Como referencial para discussão dos dados, convém apresentar alguns parâmetros empregados pela legislação vigente que dispõe sobre padrões a serem atingidos pelos efluentes. No âmbito federal, o artigo 34 da resolução do CONAMA 357 de 17 de março de 2005, dispõe sobre classificação das águas $\Theta$ estabelece as condições $\theta$ padrões de lançamentos. No Estado de São Paulo, a partir da lei $n^{\circ} 997 / 76$, os padrões de emissão são regulamentados através do decreto 8468/76, e são apresentados na tabela 7.1.

Nos gráficos, a linha pontilhada indica esses valores limites empregados pelas legislações estadual e federal a serem atingidos pelos efluentes finais antes do lançamento no corpo receptor. 
Tabela 7.1 Valores limites estabelecidos do efluente final para lançamento no corpo receptor Classe 2 de acordo com Resolução CONAMA 357/05 e Decreto 8468/76, relativos às análises realizadas.

\begin{tabular}{|l|c|c|c|}
\hline \multicolumn{1}{|c|}{ Parâmetro } & \multirow{2}{*}{ Unidade } & Lei Estadual & Lei Federal \\
\cline { 3 - 4 } & & Decreto 8468/76 & CONAMA 357/05 \\
\hline Coliformes termotderantes & $\mathrm{NMP} / 100 \mathrm{~mL}$ & & $<1000$ \\
\hline Temperatura & ${ }^{\circ} \mathrm{C}$ & $<40$ & $<40$ \\
\hline pH & & $>5,0 \theta<9,0$ & $>5,0 \theta<9,0$ \\
\hline DBO5,20 & $\mathrm{mg} \mathrm{L}$ & $<60,0$ & \\
\hline Nitrogênio amoniacal & $\mathrm{mg} \mathrm{L}$ & & $<20$ \\
\hline Sólidos sedimentáveis & $\mathrm{m} / \mathrm{L}$ & $<1,0$ & $<1,0$ \\
\hline
\end{tabular}

\subsection{Resultados das características físico-químicas e} bacteriológicas do esgoto bruto e efluente das lagoas anaeróbia e facultativa (primeira fase).

$\mathrm{Na}$ tabela 7.2 são apresentados os valores mínimos, médios e máximos das variáveis analisadas na fase 1 , durante o período de 16/08/2004 à 11/04/2005, operando com vazão média de 7,98 l/s.

Tabela 7.2 Valores mínimos, médios e máximos das variáveis analisadas durante monitoramento da ETE.

\begin{tabular}{|c|c|c|c|c|c|c|c|c|c|}
\hline & \multicolumn{3}{|c|}{ alluente lagoa aneerótia } & \multicolumn{3}{|c|}{ Elluente lagoa aneenctia } & \multicolumn{3}{|c|}{ Eluente da lagoa facultatina } \\
\hline & Mrimo & Módo & Mtaimo & Mrimo & Mado & Maximo & Mrimo & Médo & Meximo \\
\hline $\mathrm{pH}$ & 5,5 & 6.6 & 12,0 & 6,0 & 7,0 & 8,5 & 60 & 7,5 & 10,0 \\
\hline Temp ar (oO) & 17 & 2 & $\mathbf{2 6}$ & 17 & 22 & 26 & 19 & 22 & 26 \\
\hline Temp ága (oC) & 17 & 2 & 24 & 17 & 2 & 26 & 17 & $\mathbf{2 3}$ & $\mathbf{2 6}$ \\
\hline DBOSd (mgl) & 180 & $\mathbf{2 0 9}$ & 570 & 12 & 51 & 117 & 9 & 30 & $\mathbf{6 0}$ \\
\hline DBOEd fltradz(mg/4) & 111 & 145 & 186 & 8 & 27 & 58 & 7 & 20 & 47 \\
\hline Dos(mgl) & 325 & 500 & 1000 & 100 & 192 & 331 & 57 & 136 & 227 \\
\hline DeOfittracta(mgl) & 79 & 248 & 345 & 36 & 120 & $\mathbf{2 9 9}$ & 32 & 80 & $\mathbf{2 3 8}$ \\
\hline Ntrogeniototal Kjechal & 25,5 & 46,7 & 70,7 & 13,5 & $2 \%$ & 52,2 & 10,4 & $\overline{27,1}$ & 45,0 \\
\hline Ntrogénio Amoriac. & 14,8 & 23,0 & 37,2 & 9,0 & 18,9 & 394 & 7,4 & 17,4 & 30,6 \\
\hline Fósfou Tatal & 2,7 & 5,8 & 10,0 & 1,8 & 4,1 & 7,6 & 1,8 & 3,5 & 8,1 \\
\hline Otolostato & 2,1 & 4,1 & 6.1 & 1,2 & 24 & 4,7 & 0,5 & 2,3 & 5,4 \\
\hline ST(mgl) & 393 & 667 & 1221 & 225 & 300 & 500 & 233 & 32 & 431 \\
\hline SF(mgl) & 201 & 313 & 538 & 120 & 168 & 256 & 115 & 169 & 245 \\
\hline SV(mgl) & 169 & 364 & 603 & 73 & 133 & 25 & 86 & 156 & 249 \\
\hline SST (mgL) & 106 & 197 & 320 & 20 & 68 & 127 & 36 & 79 & 122 \\
\hline SSF(mgl) & 30 & 75 & 234 & 0 & 13 & 65 & 1 & 15 & 67 \\
\hline SSV(mgl) & 72 & 122 & 208 & 18 & 55 & 110 & 23 & 65 & 113 \\
\hline Sólidos sedimentécis & 1,0 & 3,3 & 8,0 & $<0,1$ & $\ll, 1$ & 1,5 & $<0,1$ & $<, 1$ & $<0,1$ \\
\hline Cota's & $1,40 E+07$ & $4,4 \sqrt{E}+07$ & $3,00 E+\infty 8$ & $1,70 E+04$ & $9,56 E+04$ & $1,70 \varepsilon+0 \bar{\sigma}$ & $5,00 E+\infty 2$ & $1,54 E+04$ & $2,20 E+05$ \\
\hline Cermotderantes & $1,10 E+06$ & $5,64 E+\infty 6$ & $1,70 E+07$ & $5,00 E+03$ & $3,05 E+04$ & $2,30 E+05$ & $3,00 E+02$ & $5,35 \mathrm{E}+\infty$ & $220 E+05$ \\
\hline
\end{tabular}




\subsubsection{Temperatura}

Conforme MENDONÇA (2000), para algumas espécies de algas, a produção ótima de oxigênio em lagoas de estabilização ocorre em temperaturas situadas entre 20 e $25^{\circ} \mathrm{C}$, com valores limites inferiores e superiores a $4{ }^{\circ} \mathrm{C}$ e $37^{\circ} \mathrm{C}$, respectivamente. Uma repentina elevação da temperatura da lagoa pode provocar o aumento das atividades das bactérias aeróbias e facultativas, multiplicando o número desses microorganismos e levando a um maior consumo da quantidade de oxigênio produzido pelas algas.

O autor cita ainda que, em relação à qualidade dos efluentes, em meses mais frios há um aumento na concentração de amônia e fósforo e uma diminuição dos sólidos em suspensão. De acordo com os resultados obtidos não houve mudanças bruscas de temperatura do líquido mesmo em épocas mais frias do ano, mantendo-se em média em torno de $22^{\circ} \mathrm{C}$ mantendo o bom desempenho da estação.

\subsubsection{Potencial hidrogeniônico (pH)}

A característica ácida dos esgotos sanitários pode ser observada na variação do $\mathrm{pH}$ do esgoto bruto, a qual variou de 5,5 a 12,0 com valor médio de 6,6. Os valores de $\mathrm{pH}$ das lagoas anaeróbias também se mantiveram com valores médios próximo a 7,0. 0 valor máximo 8,5 foi obtido após lançamento de cal na entrada da estação, pois a lagoa, em alguns momentos do monitoramento apresentou valores de $\mathrm{pH}$ abaixo de 6,5 gerando odores desagradáveis devido a intensa atividade biológica de decomposição e conseqüente acidificação que ocorre com a redução da taxa de reprodução das bactérias metanogênicas em condições de $\mathrm{pH}$ inferior a 7,0 (VON SPERLING 1996). O efluente da lagoa facultativa apresentou valores de pH entre 6,0 e 10,0, com valor médio de 7,5, o qual indica ambiente alcalino, provavelmente em função das atividades fotossintéticas realizada pelas algas (GOMES 2002). 


\subsubsection{Sólidos sedimentáveis}

A análise dos resultados de sólidos sedimentáveis indica que todas as amostras do efluente da lagoa facultativa atenderam ao limite proposto pela Resolução do CONAMA n ${ }^{\circ} 357 / 05$ para padrão de emissão máximo de $1,0 \mathrm{ml} / \mathrm{L}$. O valor máximo $8,0 \mathrm{ml} / \mathrm{L}$ de sólidos sedimentáveis obtido no esgoto bruto, ocorreu pelo fato da bomba da estação elevatória de esgoto estar quebrada durante final de semana e, ao ser colocada em funcionamento, recalcou grande quantidade de material sólido acumulado nesse período.

\subsubsection{Demanda bioquímica de oxigênio (DBO)}

Nas figuras 7.1 a 7.3 podem ser observados que, durante a realização do monitoramento, a concentração de DBO do esgoto bruto variou de $180 \mathrm{mg} / \mathrm{L}$ a $570 \mathrm{mg} / \mathrm{L}$, no efluente da lagoa anaeróbia de 12 a $117 \mathrm{mg} / \mathrm{L}$ e no efluente final de 9 a $60 \mathrm{mg} / \mathrm{L}$.

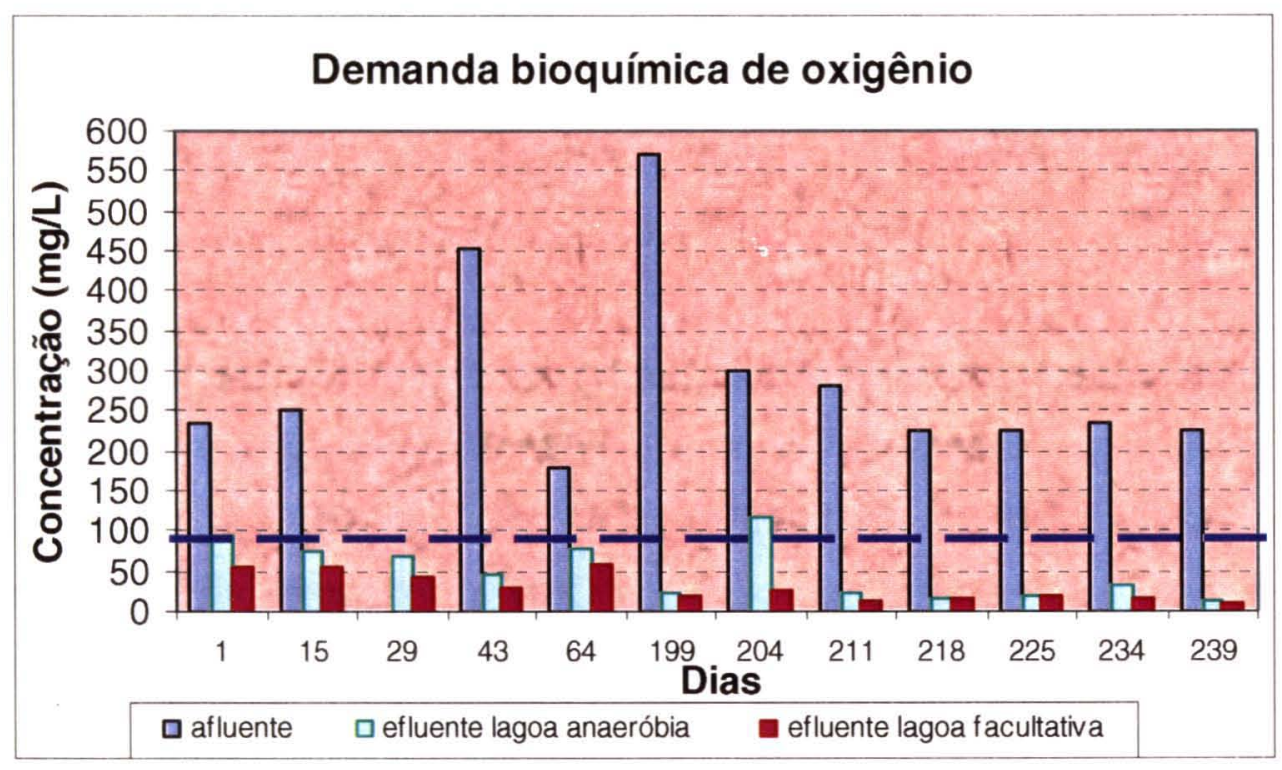

Figura 7.1 Concentração de DBO do esgoto à entrada e à saída das lagoas anaeróbia e facultativa. 


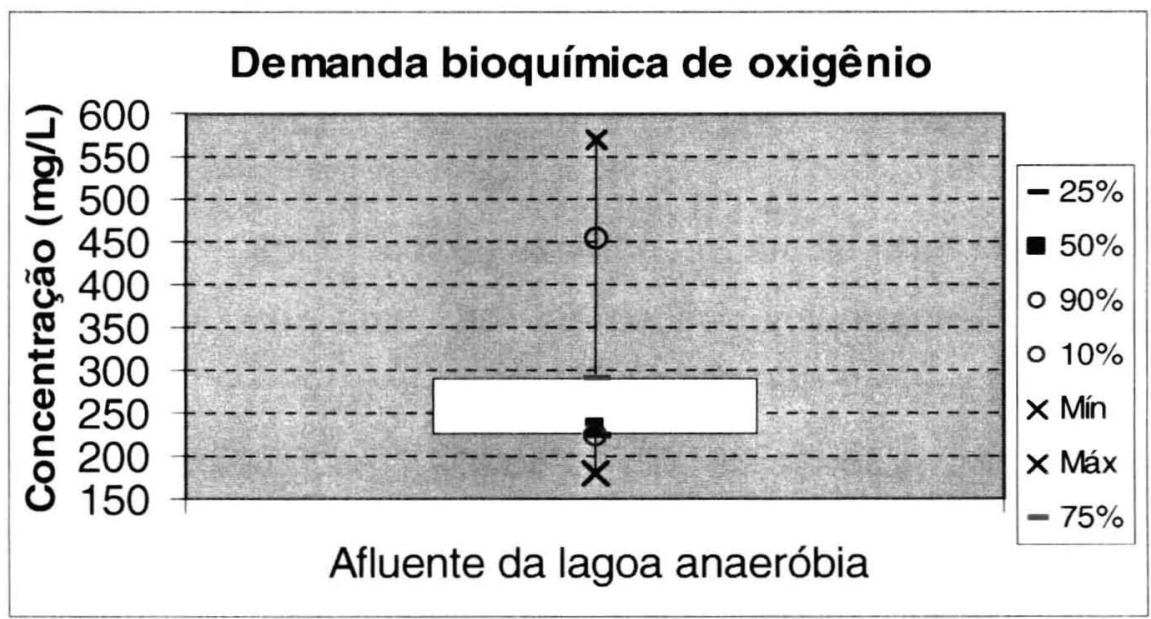

Figura 7.2 Diagramas tipo "boxplot" da concentração de DBO do esgoto à entrada da lagoa.

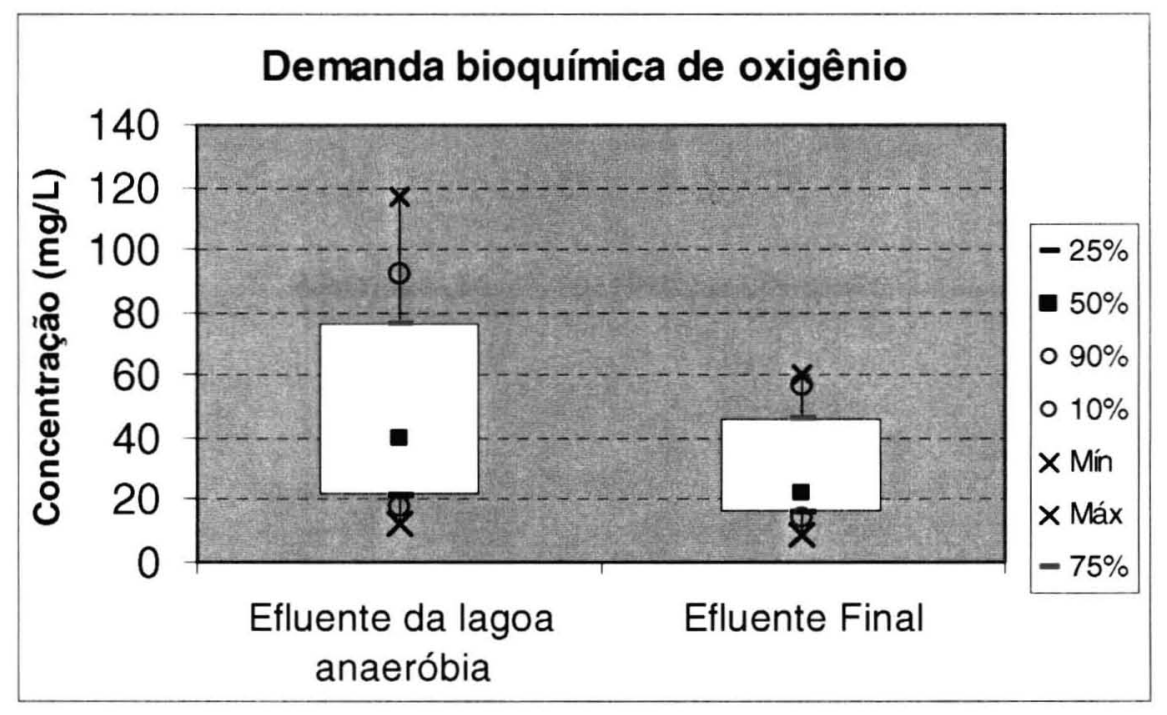

Figura 7.3 Diagramas tipo "boxplot" da concentração de DBO do esgoto à saída das lagoas anaeróbia e facultativa.

SAQQAR \& PESCOD (1995), ao realizarem experimentos em lagoas anaeróbias na Jordânia durante 48 meses, obtiveram uma remoção de DBO de 53\%. VON SPERLING (1996) ressalta que, a eficiência de remoção de DBO de lagoas anaeróbias que tenham sido projetadas a partir de modelos empíricos situa-se entre 50 e $60 \%$.

Como citado anteriormente, KAWAI (1981) ao realizar pesquisas com lagoas anaeróbias chegou à conclusão que as mesmas tendem a operar como facultativa com tempo de detenção superior a 6 dias. MARA 
(1976), sugere taxas de aplicação volumétrica $\left(\lambda_{v}\right)$ entre 100 e $400 \mathrm{gDBO}_{5} / \mathrm{m}^{3 *} \mathrm{~d}$ para garantir a anaerobiose da lagoa.

A lagoa anaeróbia apresentou em média uma eficiência de 80,85\% (figura 7.4) e taxa de aplicação volumétrica variando de 24 a $75 \mathrm{~g} \mathrm{DBO} / \mathrm{m}^{3}$.d e tempo de detenção hidráulico (TDH) de 7,5 dias. A lagoa facultativa com TDH de 27 dias apresentou uma taxa de aplicação superficial máxima de $148 \mathrm{~kg} \mathrm{DBO}_{5} /$ ha.d, considerado como valor típico adotado para regiões com inverno e insolação moderados. No projeto de dimensionamento da lagoa facultativa foi adotado valor de $166 \mathrm{~kg}$ $\mathrm{DBO}_{5} /$ ha.d. O sistema apresentou em média uma eficiência de remoção de DBO de $90,54 \%$, valor próximo ao esperado no projeto (90\%) e, o efluente final, durante todo o monitoramento apresentou concentração inferior a $60 \mathrm{mg} / \mathrm{L}$, sendo este, o valor máximo exigido para lançamento de efluentes proposto pelo Decreto 8468/76.

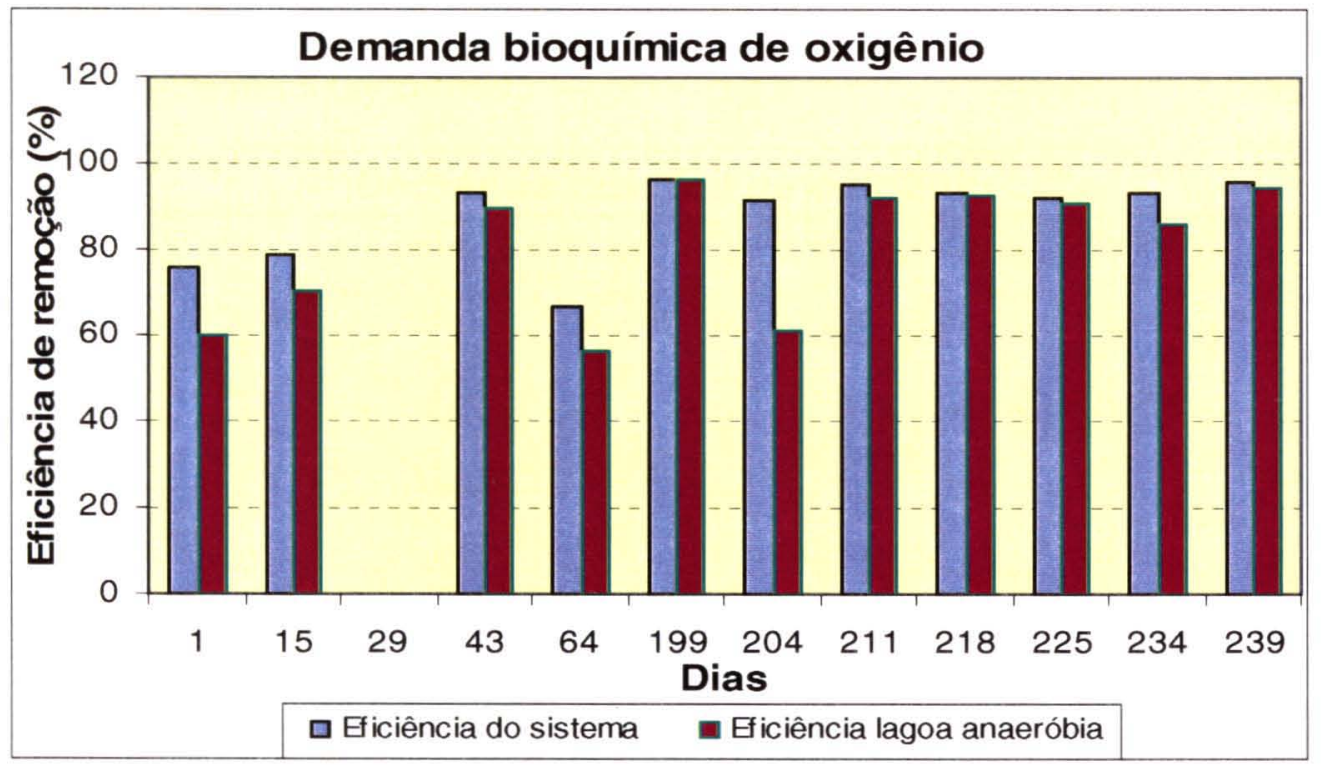

Figura 7.4 Eficiência de remoção de DBO do sistema e da lagoa anaeróbia.

\subsubsection{Demanda química de oxigênio (DQO)}

Conforme PIVELI (1996), é comum serem aplicados tratamentos biológicos para esgotos com relações de DQO/DBO de 3/1. Entretanto, 
valores superiores a essa relação indicam pouca fração biodegradável, sendo prejudicial ao tratamento biológico pelo efeito tóxico sobre os microorganismos.

A tabela 7.2 indica que a relação média $\mathrm{DQO} / \mathrm{DBO}$ dos esgotos afluentes a lagoa anaeróbia é de $2 / 1$ e do efluente da lagoa facultativa é de 5/1. A relação DQO/DBO do afluente indica melhor eficiência ao se empregar o tratamento biológico e, a relação $5 / 1$ indica que 0 tratamento atuou de forma considerável sobre a matéria orgânica, aumentando esta relação.

O afluente da lagoa anaeróbia apresentou uma variabilidade nos resultados de DQO (325 a $1000 \mathrm{mg} / \mathrm{L}$ ) com um valor médio de $590 \mathrm{mg} / \mathrm{L}$. A lagoa anaeróbia apresentou valor médio de DQO de $192 \mathrm{mg} / \mathrm{L}$ e a lagoa facultativa $136 \mathrm{mg} / \mathrm{L}$. Como pode ser observado nas figuras 7.5 a 7.7 , os valores de concentração do efluente da lagoa anaeróbia e facultativa se mantiveram mais uniformes.

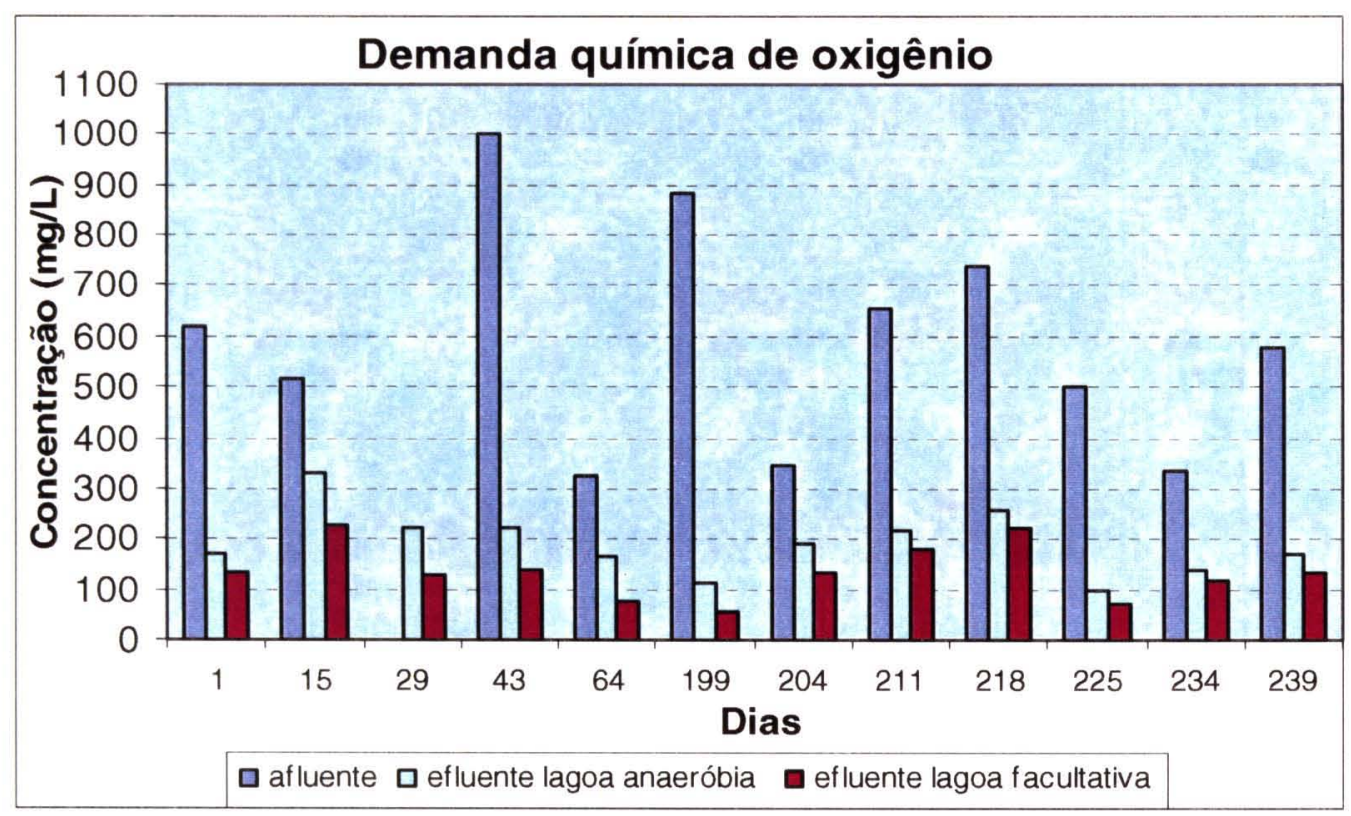

Figura 7.5 Concentração de DQO do esgoto à entrada e à saída das lagoas anaeróbia e facultativa. 


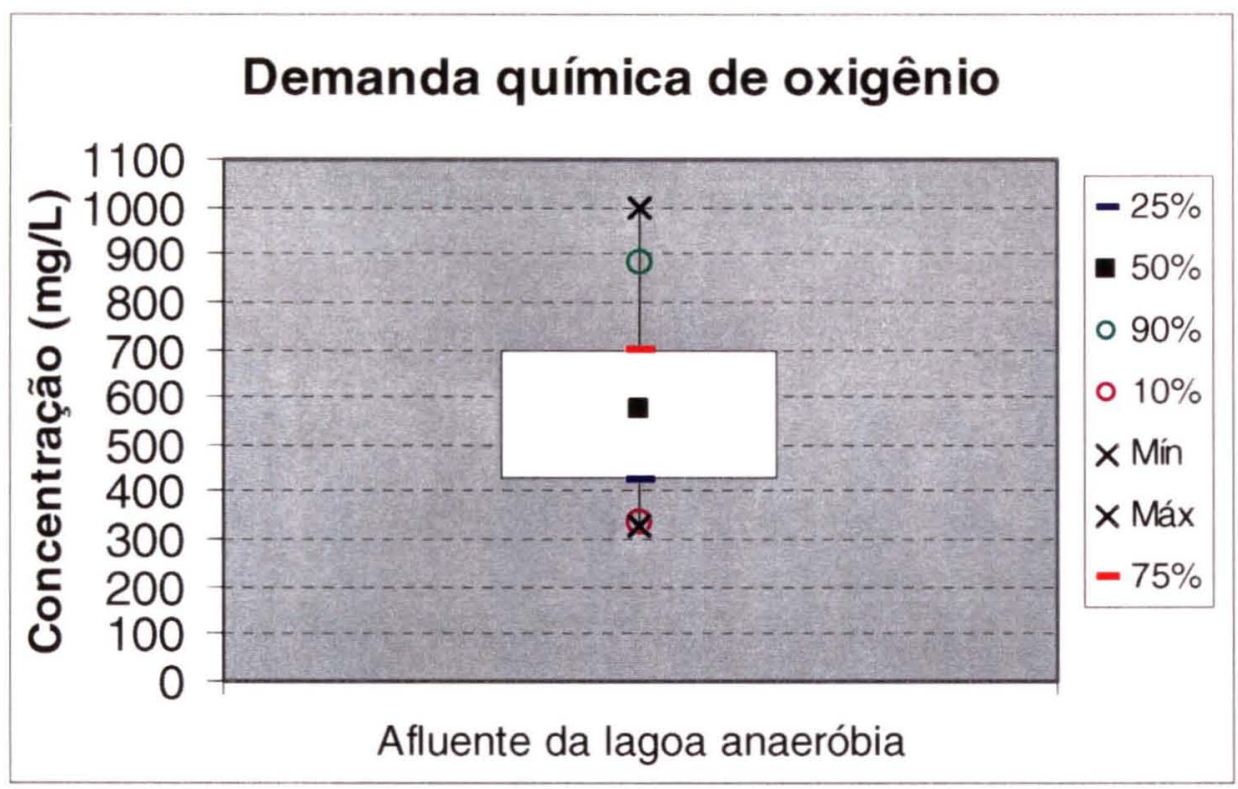

Figura 7.6 Diagramas tipo "boxplot" da concentração de DQO do esgoto à entrada da lagoa anaeróbia.

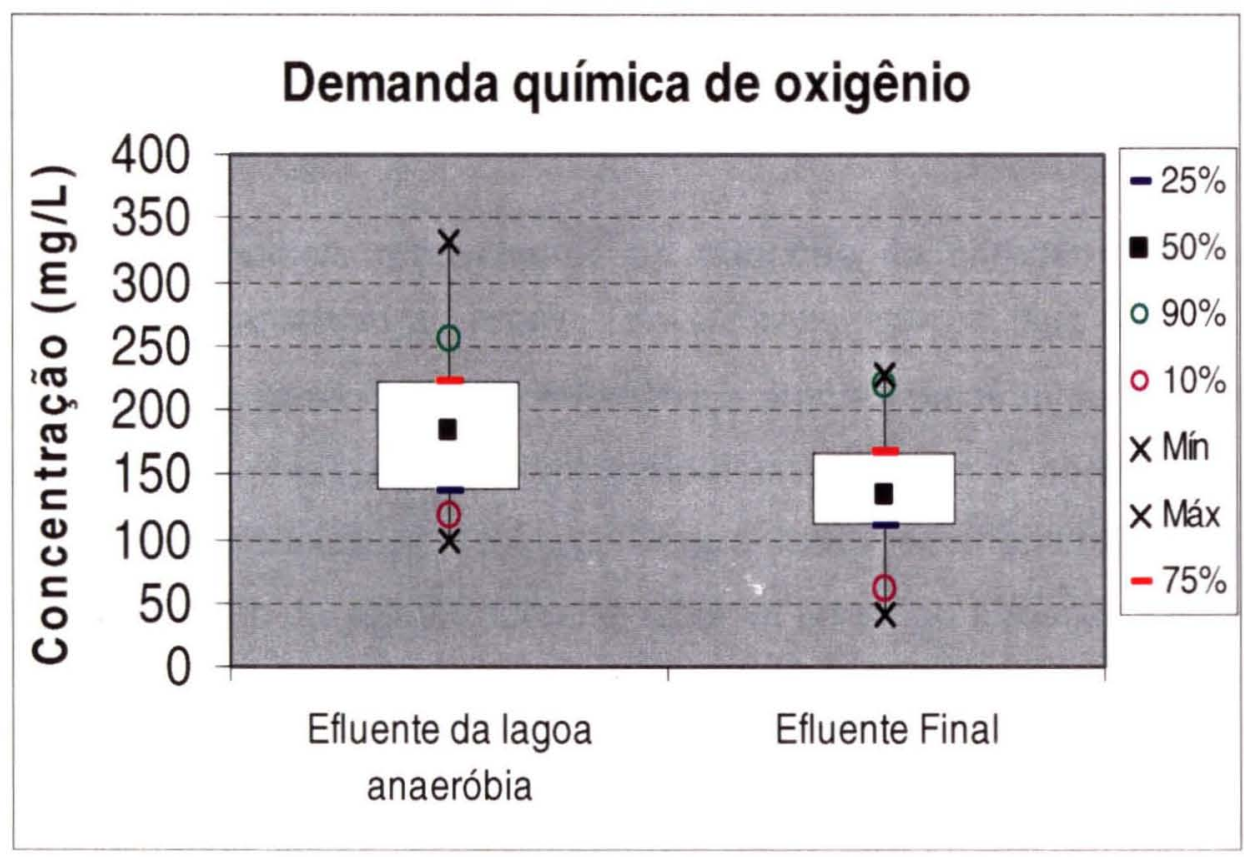

Figura 7.7 Diagramas tipo "boxplot" da concentração de DQO do esgoto à saída das lagoas anaeróbia e facultativa. 
As porcentagens médias de remoção de DQO obtidas na lagoa anaeróbia e no sistema são respectivamente $64,9 \%$ e $74,7 \%$ (figura 7.8 ).

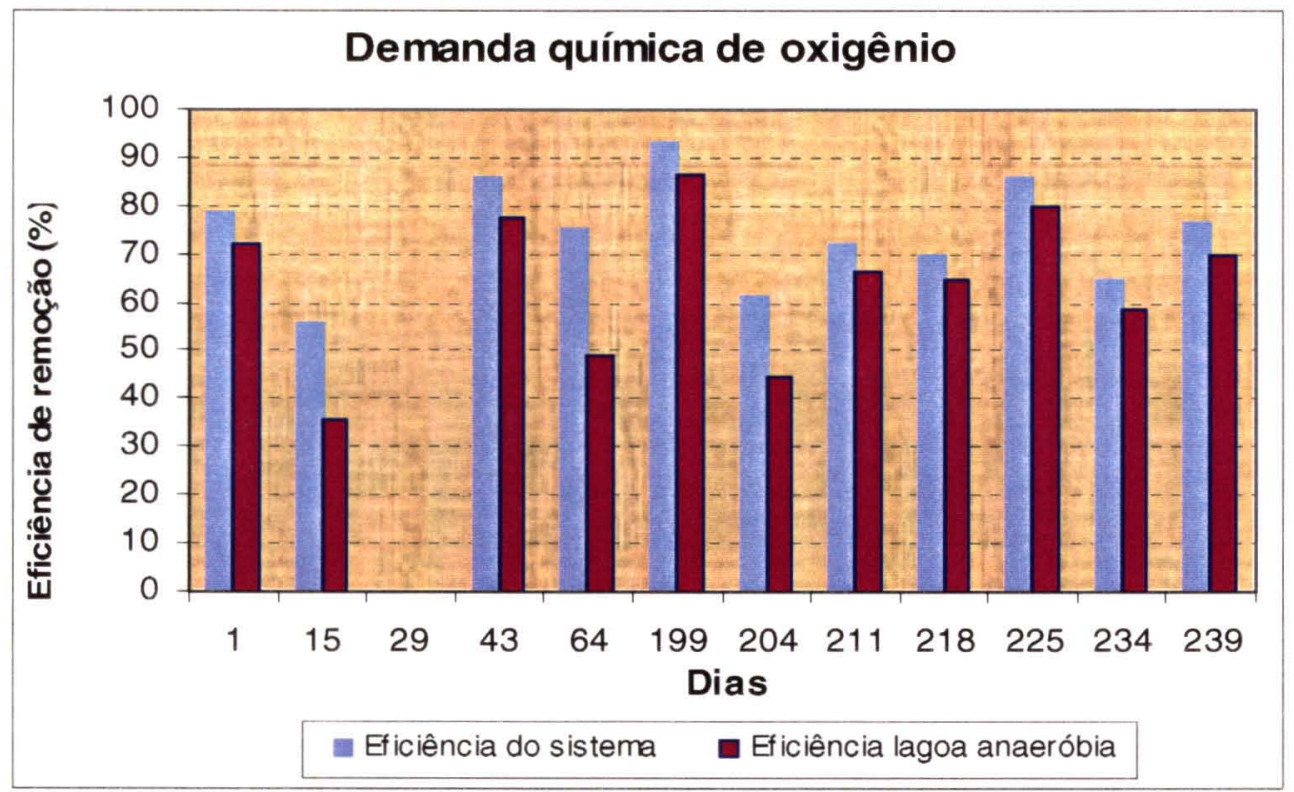

Figura 7.8 Eficiência de remoção de DQO do sistema e da lagoa anaeróbia

\subsubsection{Nitrogênio Total Kjedhal (NKT) e Nitrogênio Amoniacal}

Os principais mecanismos de remoção de nitrogênio em lagoas, segundo ARCEIVALA (1981) apud VON SPERLING (1996), são: volatilização da amônia, assimilação da amônia pelas algas, assimilação dos nitratos pelas algas, nitrificação-desnitrificação e sedimentação do nitrogênio orgânico particulado. Dentre todos os mecanismos, o mais importante é o da volatilização da amônia, segundo a reação abaixo:

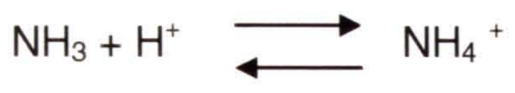

Conforme METCALF \& EDDY (2003), a concentração de nitrogênio total nos esgotos brutos varia de 20 a $85 \mathrm{mg} / \mathrm{L}$ (considerado esgoto fraco a forte), enquanto o nitrogênio amoniacal varia de 12 a $50 \mathrm{mg} / \mathrm{L}$. No presente trabalho, foram encontradas variações de concentração de nitrogênio total de 25,5 a $70,7 \mathrm{mg} / \mathrm{L}$, com valor médio de $46,7 \mathrm{mg} / \mathrm{L}$. O 
nitrogênio amoniacal apresentou variação de concentração de 14,8 a $37,2 \mathrm{mg} / \mathrm{L}$, com valor médio de $28,0 \mathrm{mg} / \mathrm{L}$. (figuras 7.9 a 7.11 ).

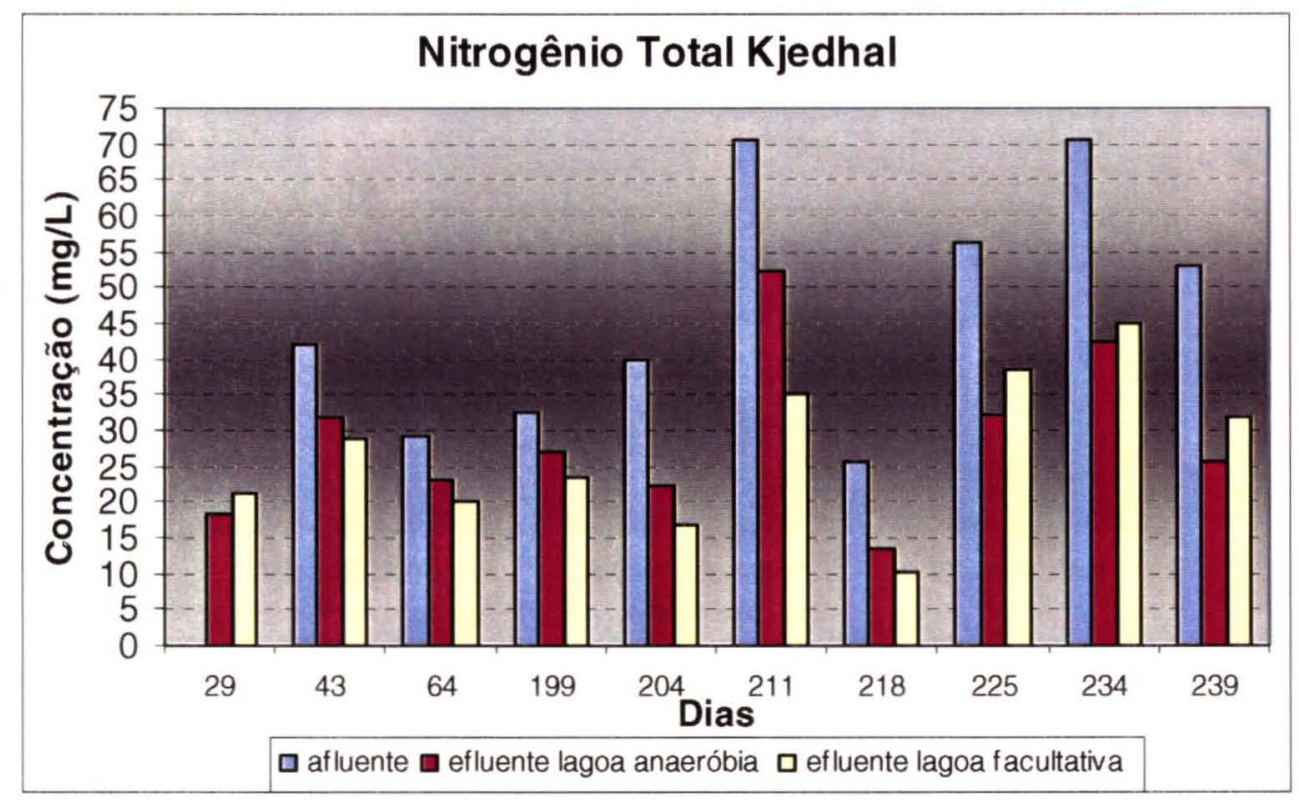

Figura 7.9 Concentração de Nitrogênio total (NKT) do esgoto à entrada e à saída das lagoas anaeróbia e facultativa.

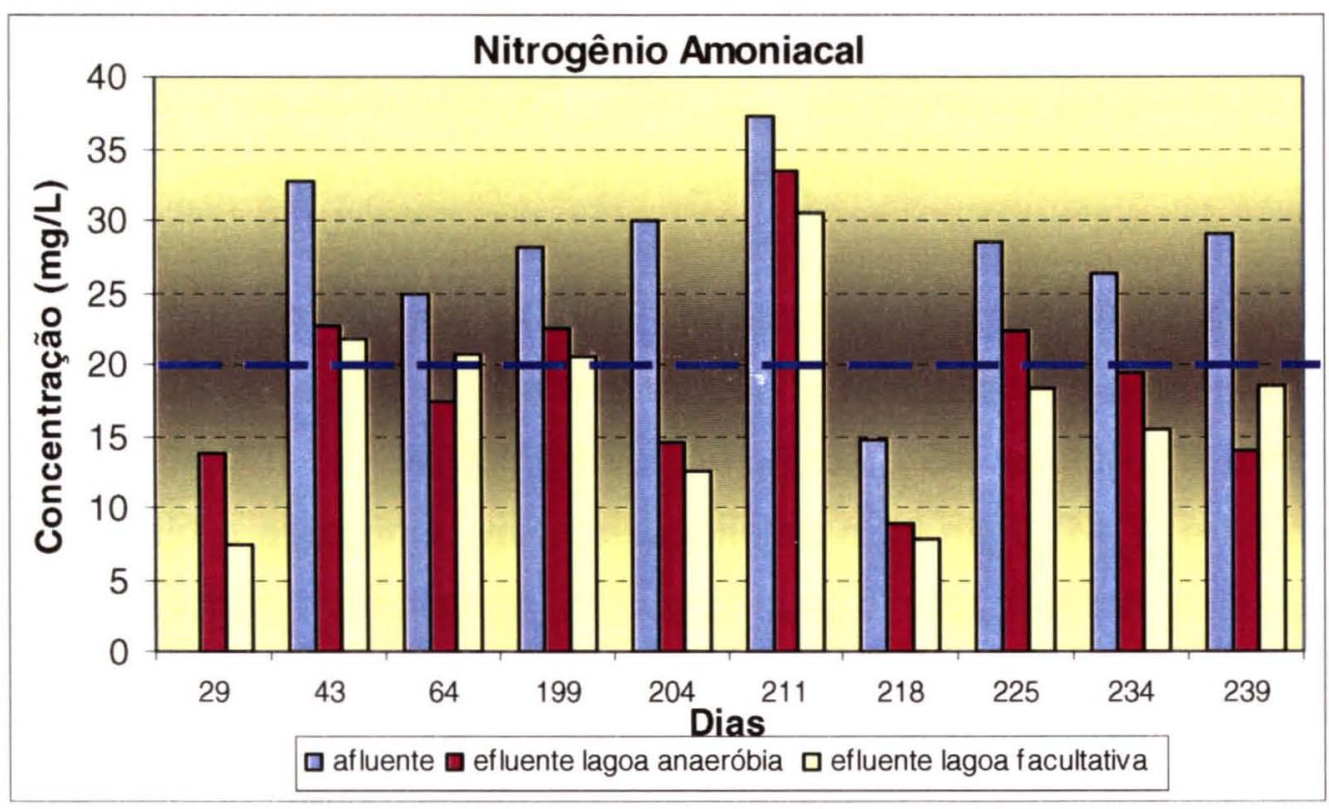

Figura 7.10 Concentração de Nitrogênio amoniacal do esgoto à entrada e à saída das lagoas anaeróbia e facultativa. 


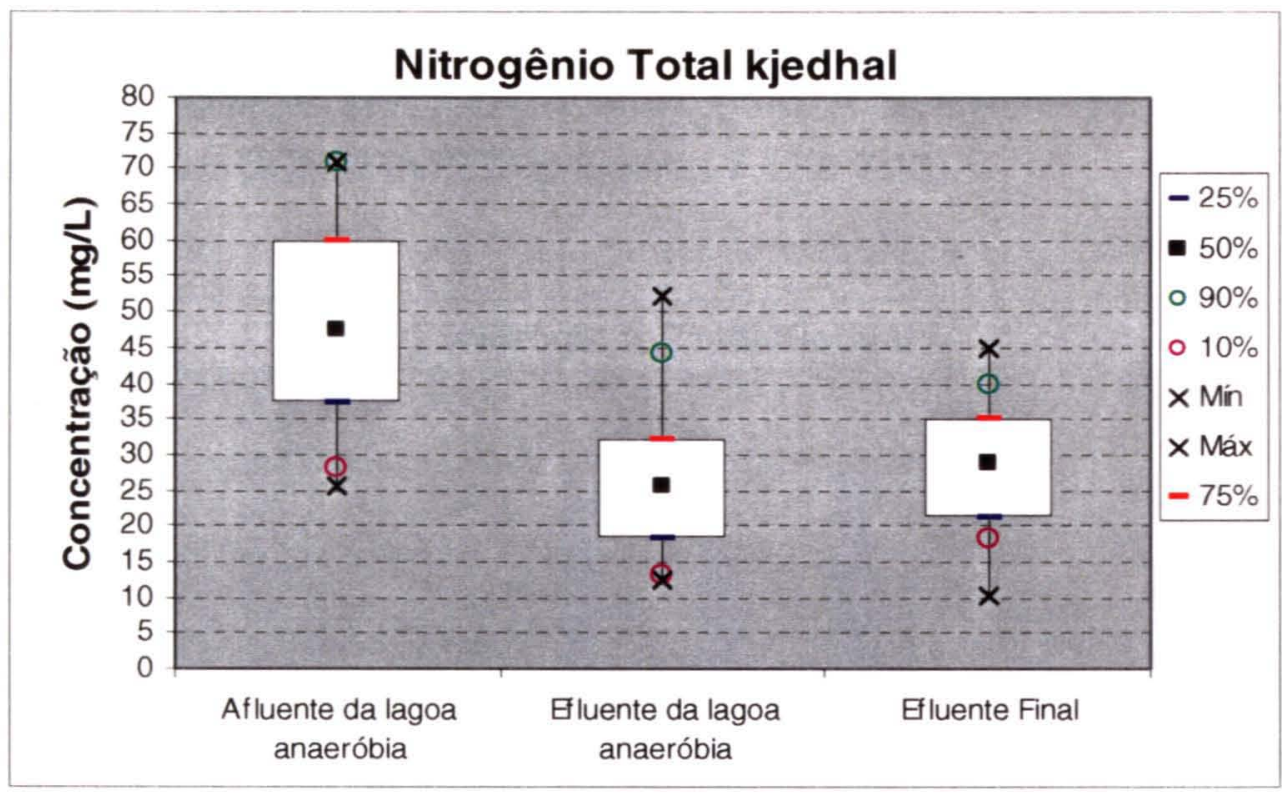

Figura 7.11 Diagramas tipo "boxplot" da concentração de Nitrogênio Total (NKT) do esgoto à entrada e à saída das lagoas anaeróbia e facultativa.

A amônia livre $\left(\mathrm{NH}_{3}\right)$, é passível de volatilização, ao contrário da amônia ionizada $\left(\mathrm{NH}_{4}{ }^{+}\right)$que não pode ser removida por volatilização. Para que a remoção da amônia gasosa seja de pelo menos $50 \%$, o pH deve situar-se acima de 9,5, além do aumento da temperatura que também favorece a liberação desse gás (YÁNEZ 1993).

PIVELI (2003), em trabalhos realizados na lagoa de estabilização do município de Lins (SP) observou pouca remoção de Nitrogênio Total Kjedhal (NKT) e de Nitrogênio Amoniacal. Os esgotos à entrada chegaram a apresentar valores superiores a $60 \mathrm{mg} / \mathrm{L}$ (NKT) e $50 \mathrm{mg} / \mathrm{L}$ para Nitrogênio Amoniacal, enquanto que, o efluente final apresentou valores superiores a $40 \mathrm{mg} / \mathrm{L}$ e $30 \mathrm{mg} / \mathrm{L}$, respectivamente.

Neste trabalho foram observadas remoções de NKT e Nitrogênio Amoniacal do sistema da ordem de $40,5 \%$ e $34,8 \%$ respectivamente. Em algumas coletas, quando $\mathrm{opH}$ atingiu valores próximos a 10,0, foram notadas eficiências de remoção superiores a $70 \%$. O efluente final 
apresentou média de 27,1 mg/L para Nitrogênio Total e 17,4 mg/L para Nitrogênio Amoniacal. Com relação ao nitrogênio amoniacal, em algumas fases do monitoramento, o efluente final atendeu os valores exigidos pelo CONAMA 357/05 (figuras 7.12 e 7.13).

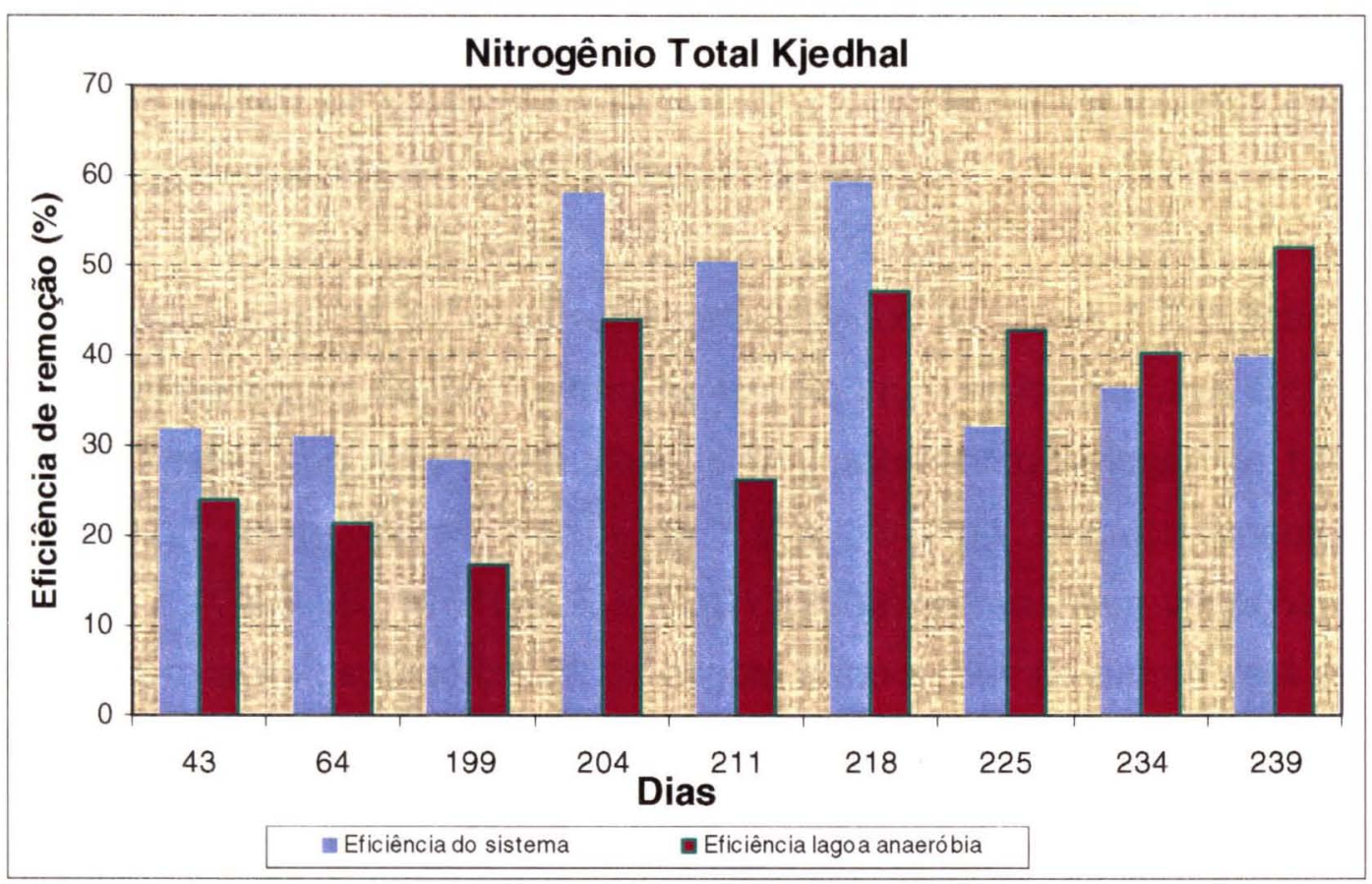

Figura 7.12 Eficiência de remoção de Nitrogênio Total (NKT).

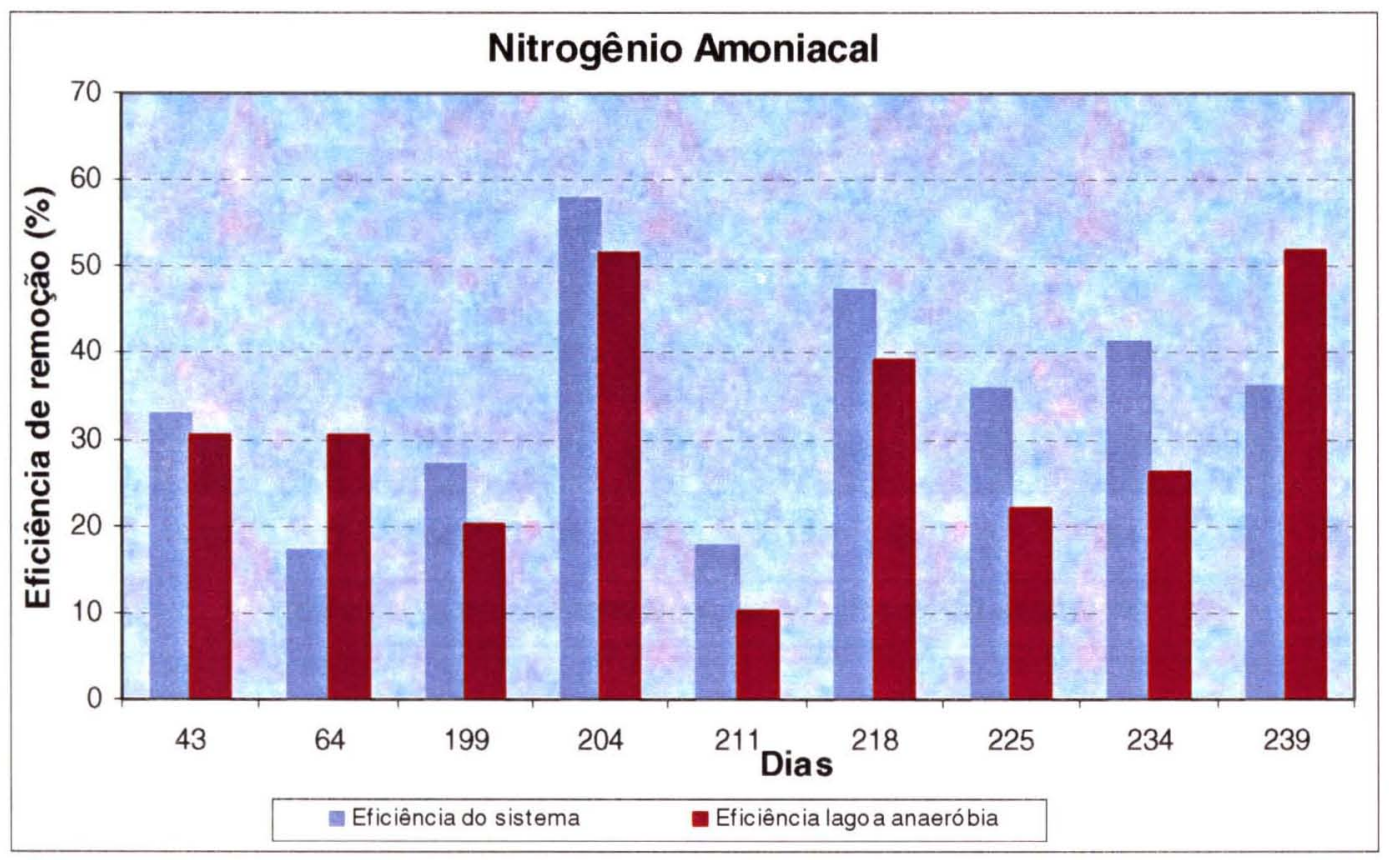

Figura 7.13 Eficiência de remoção de Nitrogênio Amoniacal. 


\subsubsection{Fósforo Total}

Nos esgotos, o fósforo é composto por fósforo orgânico e fosfato, sendo que os últimos representam sua maioria. Em lagoas de estabilização, os mecanismos de remoção desses nutrientes podem ocorrer de várias formas: retirada de fósforo orgânico contido nas algas e bactérias através da saída do efluente final e precipitação de fosfatos em condições de elevado pH (VON SPERLING 1996).

Nesta pesquisa, os resultados apresentados na tabela 7.2 indicam que a concentração de fósforo total no esgoto bruto variou na faixa entre 2,7 e $10 \mathrm{mg} / \mathrm{L}$, enquanto que o efluente final apresentou variação de 1,8 a $8,1 \mathrm{mg} / \mathrm{L}$, com valores médios de 5,8 e $3,5 \mathrm{mg} / \mathrm{L}$ respectivamente (figuras 7.14 e 7.15). METCALF \& EDDY (2003), apresentam variações de concentração de fósforo total de esgoto fraco a forte da ordem de 4 a $15 \mathrm{mg} / \mathrm{L}$.

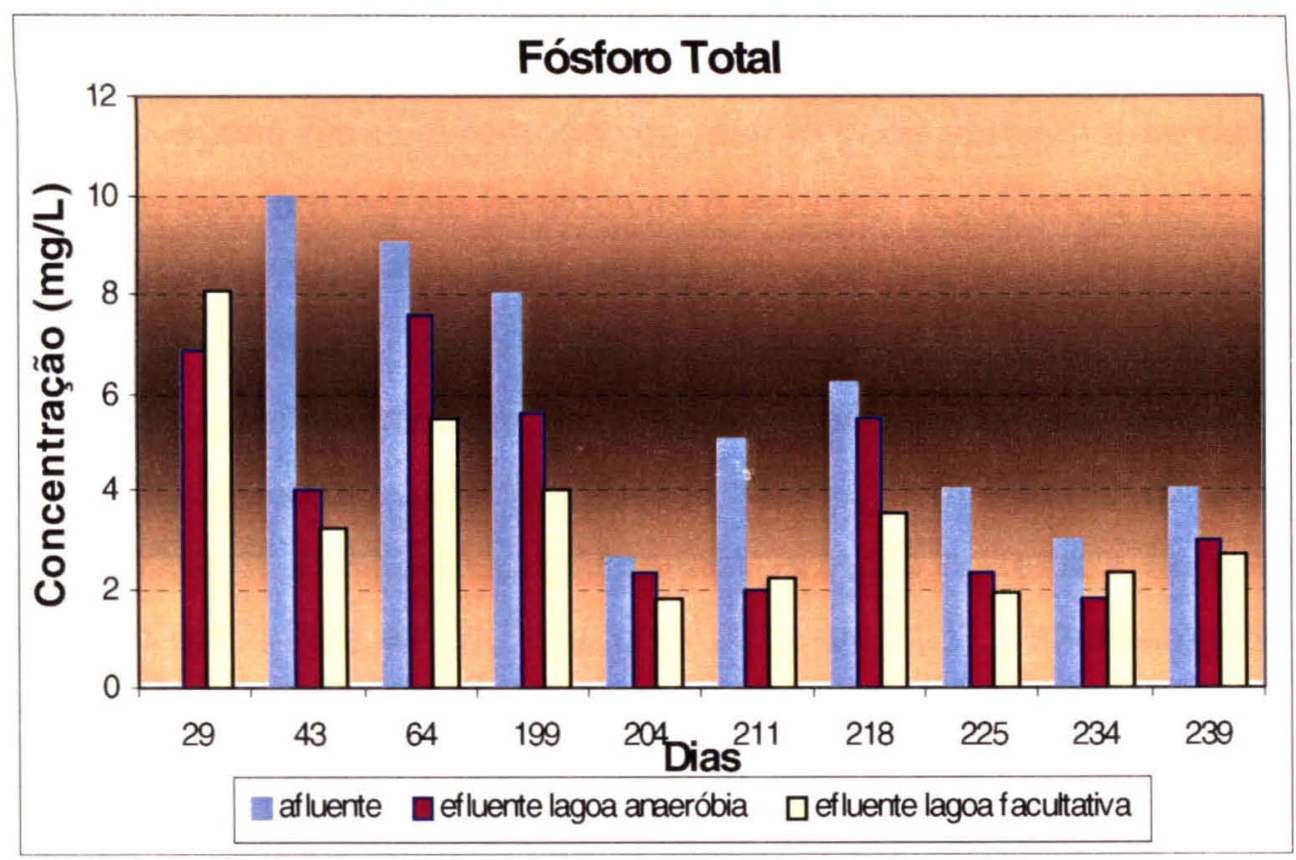

Figura 7.14 Concentração de Fósforo Total do esgoto à entrada e à saída das lagoas anaeróbia e facultativa. 


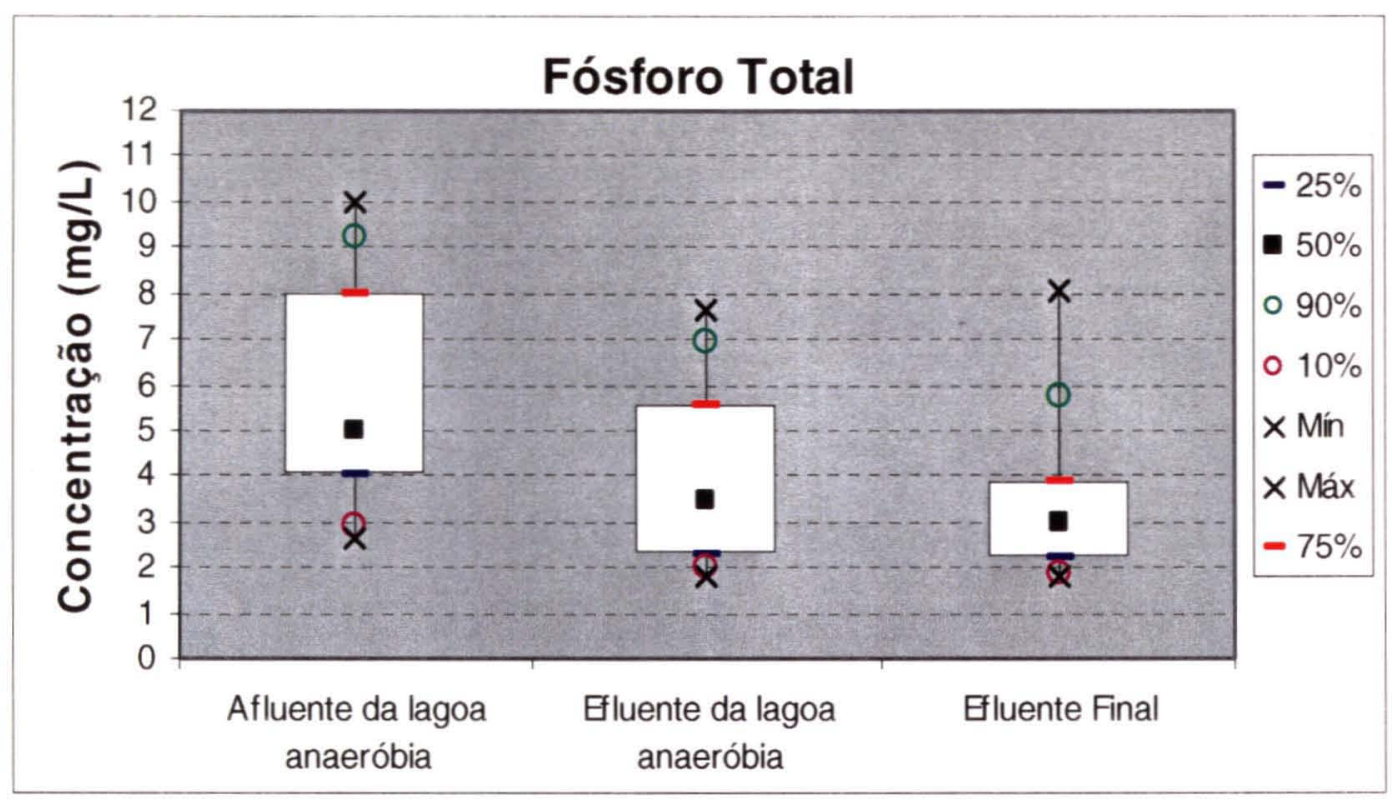

Figura 7.15 Diagramas tipo "boxplot" da concentração de Fósforo Total do esgoto à entrada e à saída das lagoas anaeróbia e facultativa.

Em condições de $\mathrm{pH}$ acima de 8,2 podem ocorrer significativas remoções de fósforo através da precipitação do fosfato na forma de hidroxiapatita $\left(\mathrm{Ca}_{5}\left(\mathrm{PO}_{4}\right)_{3} \mathrm{OH}\right)$ ou estruvita (MARA et al 1992).

Em lagoas rasas, a remoção do fósforo pode aproximar-se de $90 \%$, enquanto que, em lagoas facultativas e aeradas, a eficiência pode variar de 20 a 60\% (VON SPERLING 1996).

No presente trabalho, o sistema apresentou em média uma eficiência de remoção de fósforos de $46,7 \%$, com valores máximos e mínimos de 68 e $32 \%$ respectivamente. A lagoa anaeróbia apresentou remoção em média de $31,96 \%$, com picos de $60 \%$, provavelmente em função da elevação do $\mathrm{pH}$ em alguns momentos do período do monitoramento (figura 7.16). 


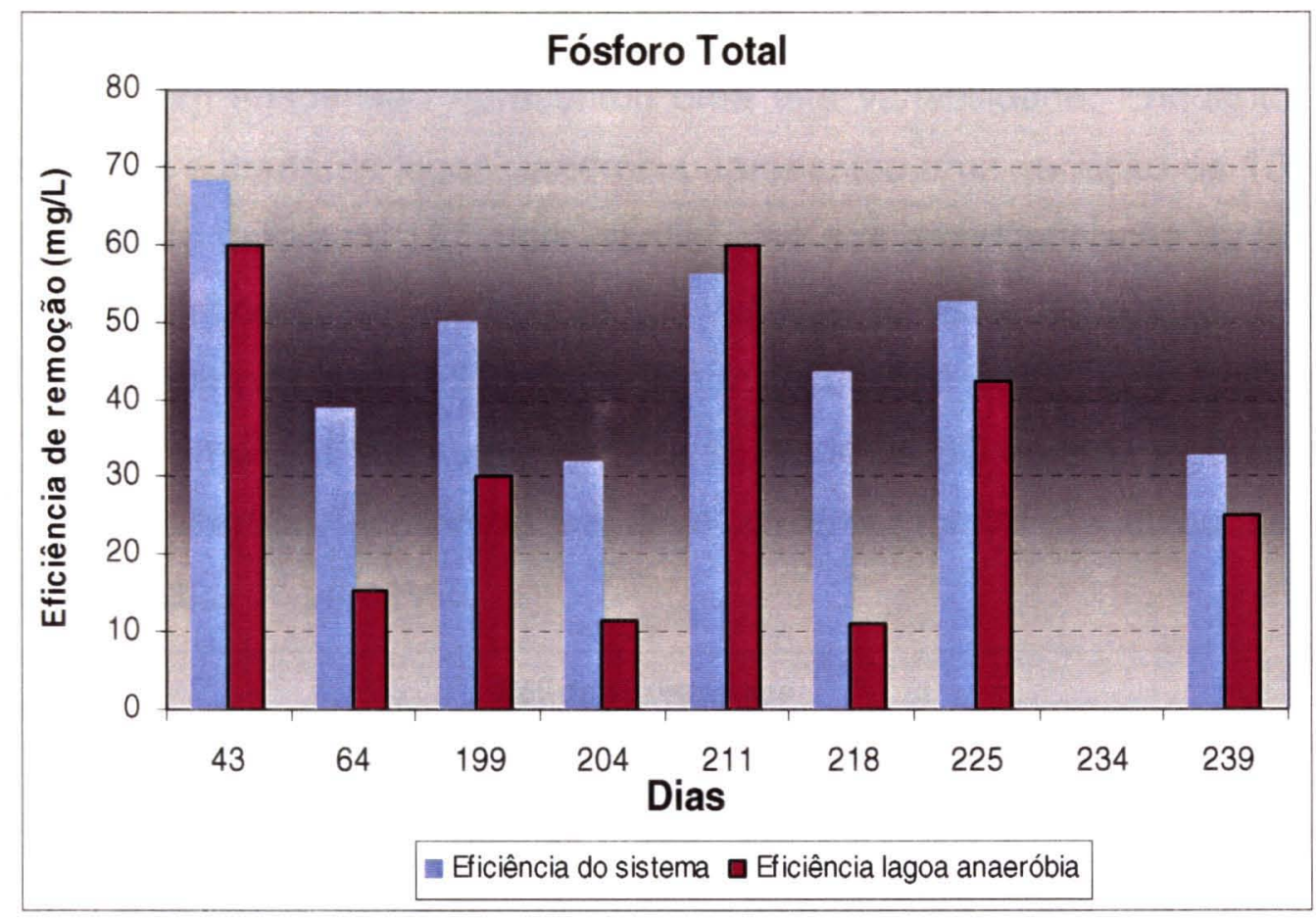

Figura 7.16 Eficiência de remoção de Fósforo Total.

\subsubsection{Sólidos em suspensão (SS)}

A razão entre a concentração dos sólidos voláteis e dos sólidos totais indica de uma maneira geral a porcentagem de material orgânico nos sólidos totais. Segundo GOMES (2002), quanto menor a relação SV/ST, menor será quantidade de matéria orgânica presente no esgoto e, é possível que a aplicação de processos biológicos não seja recomendável, podendo-se optar por processos químicos e físicos.

Conforme METCALF \& EDDY (2003), em esgotos sanitários com características de médio a forte (tabela 5.1 ), $75 \%$ dos sólidos suspensos e $40 \%$ dos sólidos dissolvidos são orgânicos. No presente estudo foram encontradas relações médias de SVT/ST $=0,61$ e SSV/SS $=0,62$, indicando a predominância de matéria orgânica e como conseqüência, a plena aplicabilidade do tratamento biológico, como é o caso de lagoas de estabilização. 
Nas figuras 7.17 a 7.19, pode se verificar que a concentração de sólidos em suspensão apresentou uma alta variabilidade. Enquanto, o esgoto à entrada da lagoa anaeróbia apresentou uma variação de 106 a $320 \mathrm{mg} / \mathrm{L}$ e média de $197 \mathrm{mg} / \mathrm{L}$, verificou-se que a concentração de SS à saída da lagoa anaeróbia apresentou variação na faixa de 20 a 127 mg/L (média 68mg/L) e do efluente da lagoa facultativa entre 36 e 122mg/L (média $79 \mathrm{mg} / \mathrm{L}$ ). Esse aumento na quantidade de SS de uma lagoa para outra (anaeróbia/facultativa) se deve ao crescimento de algas nesta última etapa do processo.

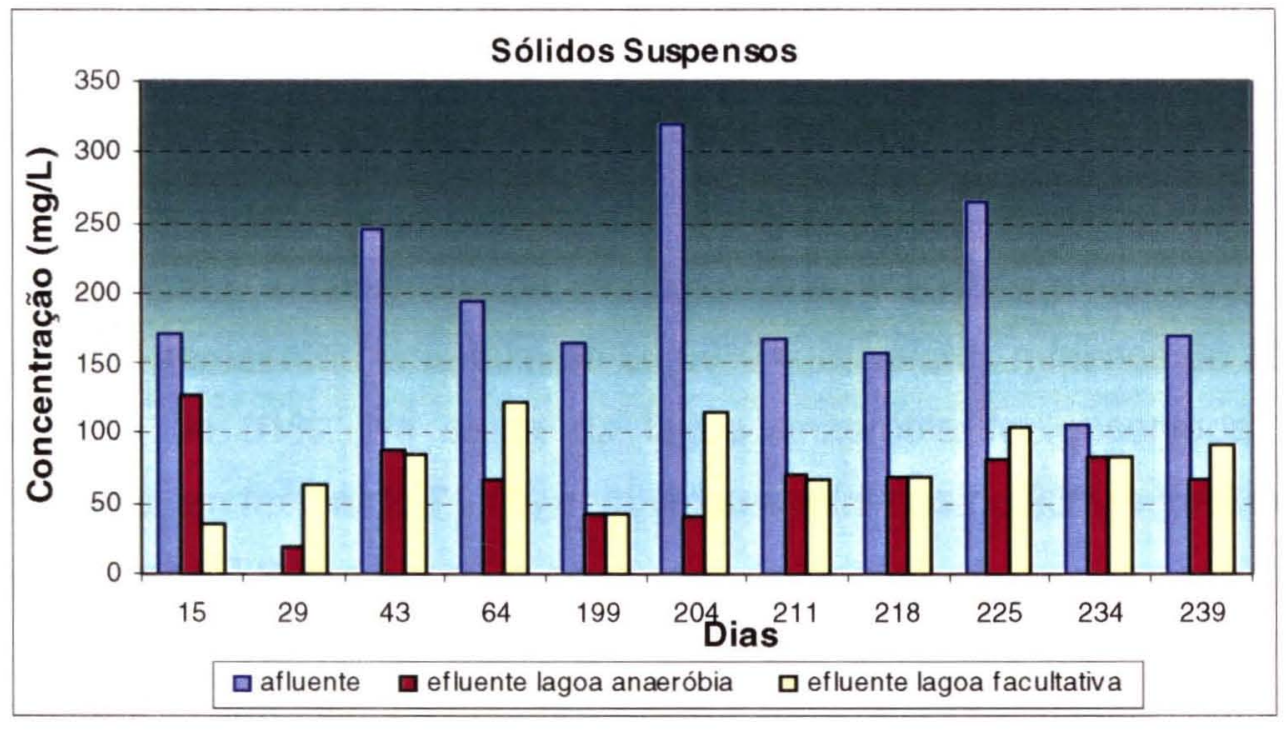

Figura 7.17 Concentração de SS do esgoto à entrada e à saída das lagoas anaeróbia e facultativa.

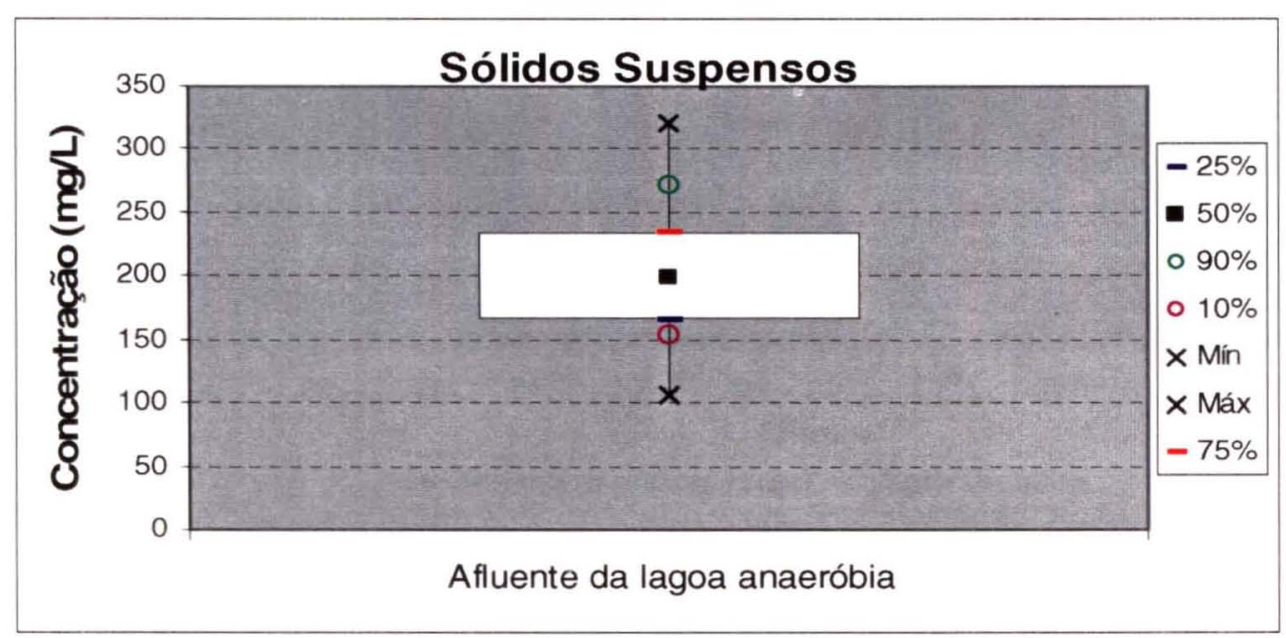

Figura 7.18 Diagramas tipo "boxplot" da concentração de SS do esgoto à entrada da lagoa anaeróbia. 


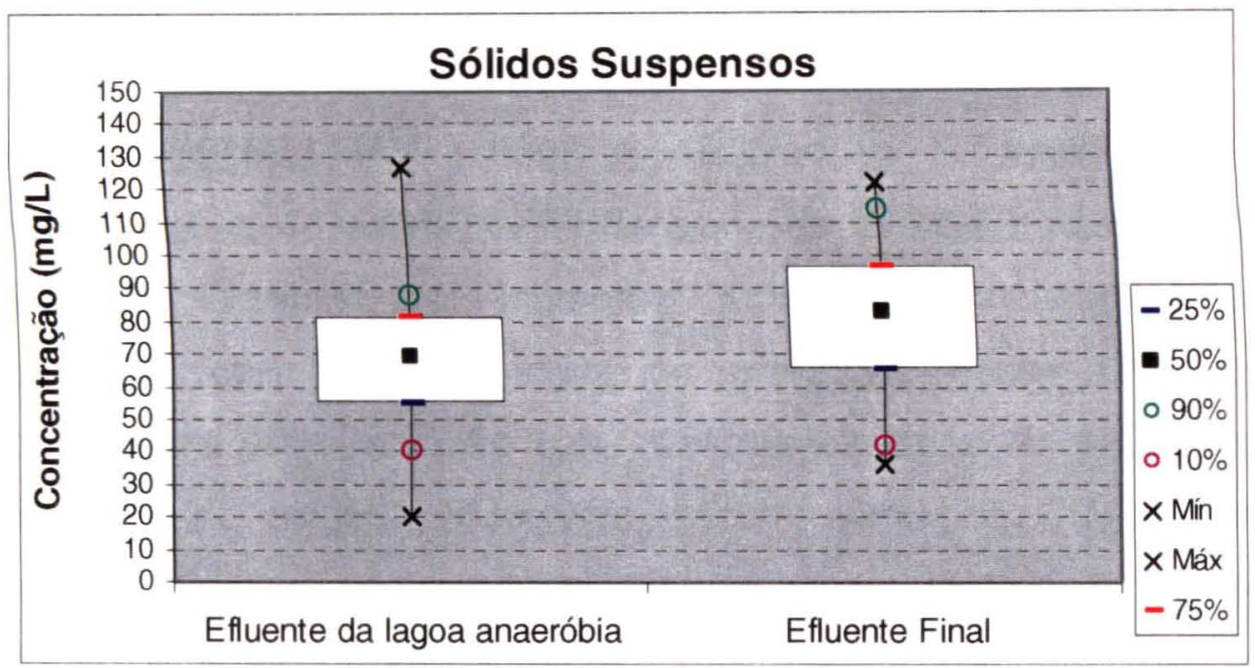

Figura 7.19 Diagramas tipo "boxplot" da concentração de SS do esgoto à saída das lagoas anaeróbia e facultativa.

Quanto à eficiência de remoção dos sólidos em suspensão, o sistema apresentou uma taxa de $66,06 \%$ com valores mínimos de $22 \%$ e máximo de 91\%. Na saída da lagoa anaeróbia foi observada uma remoção em média de $71,4 \%$ com valores mínimos de $23 \%$ e máximo de $95 \%$ (figura 7.20 ).

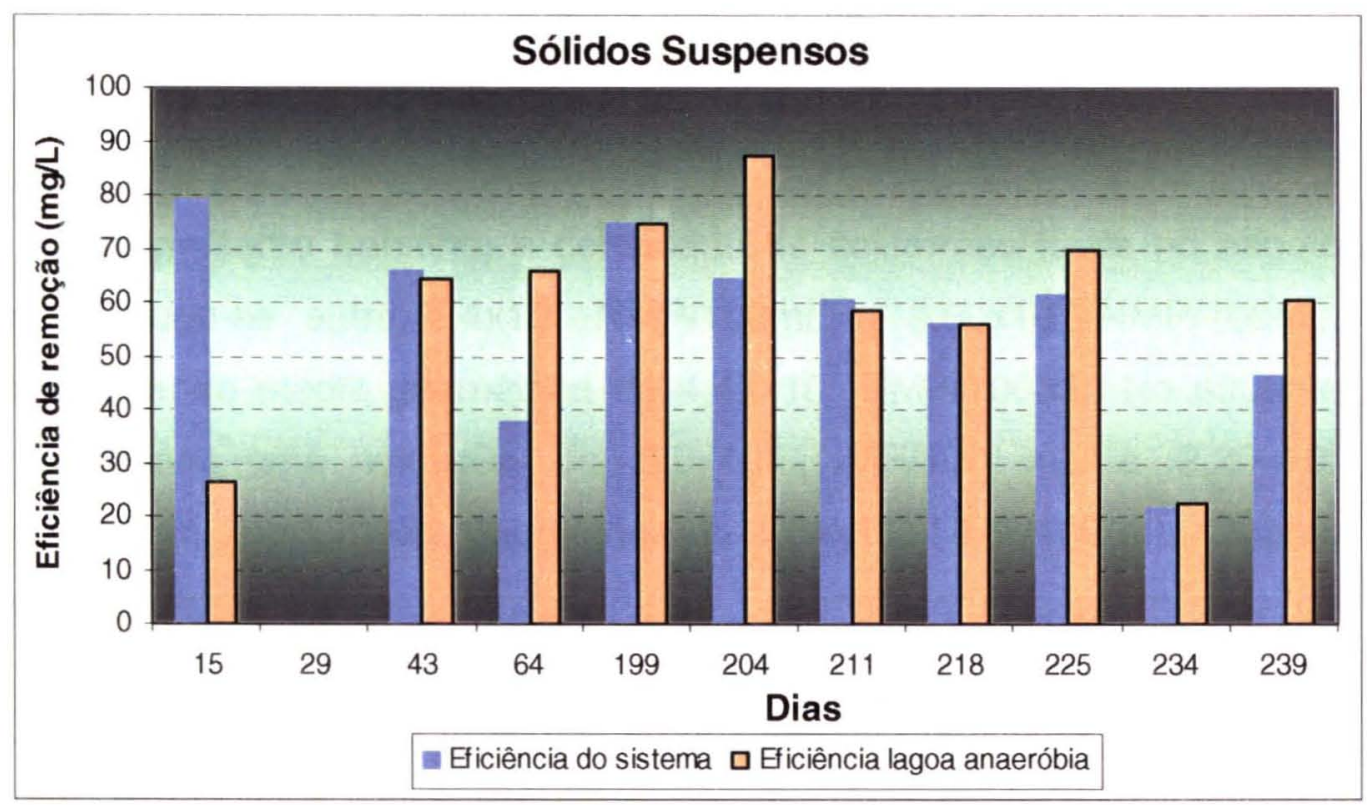

Figura 7.20 Eficiência de remoção de SS do sistema e da lagoa anaeróbia. 


\subsubsection{Coliformes totais e coliformes termotolerantes}

Conforme SMALLMAN (1986), a desinfecção do esgoto pelo emprego de lagoas de estabilização depende de fatores ambientais e climatológicos. O autor cita inúmeros fatores que influenciam a eliminação de coliformes $\theta$ patógenos presentes nesse tipo de tratamento, entre eles: radiação solar, valores elevados de $\mathrm{pH}$, altas concentrações de oxigênio dissolvido, baixos níveis de $\mathrm{CO}_{2}$, efeito bactericida de toxinas produzidas pelas algas, presença de organismos predadores e tempo de permanência.

PEARSON et al (1987) apud KELLNER (1998), após monitoramento de efluentes de lagoas de estabilização em Portugal, indicaram que $\mathrm{pH}$ com valores superiores a 9,0 aceleram o decaimento de coliformes termotolerantes em lagoas de estabilização.

SILVA (1988), ao analisar uma série de 5 lagoas de estabilização, sendo a primeira anaeróbia $\theta$ as demais facultativas, sugere que quanto a remoção de patógenos, melhores resultados são obtidos quando são utilizadas lagoas em série, ao invés de se utilizar uma lagoa única com tempo de detenção hidráulico igual ao da série.

No presente trabalho, a densidade de coliformes totais no esgoto bruto situou-se entre $1,4 \times 10^{7} \mathrm{NMP} / 100 \mathrm{~mL}$ e $3,00 \times 10^{8} \mathrm{NMP} / 100 \mathrm{~mL}$, apresentando média geométrica de $4,47 \times 10^{7} \mathrm{NMP} / 100 \mathrm{~mL}$. No efluente final houve uma variação de $5,0 \times 10^{2} \mathrm{NMP} / 100 \mathrm{~mL}$ a $2,20 \times 10^{5}$ $\mathrm{NMP} / 100 \mathrm{~mL}$, com média geométrica de $1,54 \times 10^{4} \mathrm{NMP} / 100 \mathrm{~mL}$. Quanto aos coliformes termotolerantes, foram observados valores médios de $5,64 \times 10^{6}$ no esgoto bruto, $3,05 \times 10^{4} \mathrm{NMP} / 100 \mathrm{~mL}$ na saída da lagoa anaeróbia e $5,33 \times 10^{3}$ no efluente final, como mostram as figuras 7.21 a 7.26 . 
Em relação à média geométrica, o sistema apresentou remoção de coliformes totais e coliformes termotolerantes na ordem de $99,9 \%(3,4$ unid. log) e 99,9\% (3 unid. log) respectivamente.

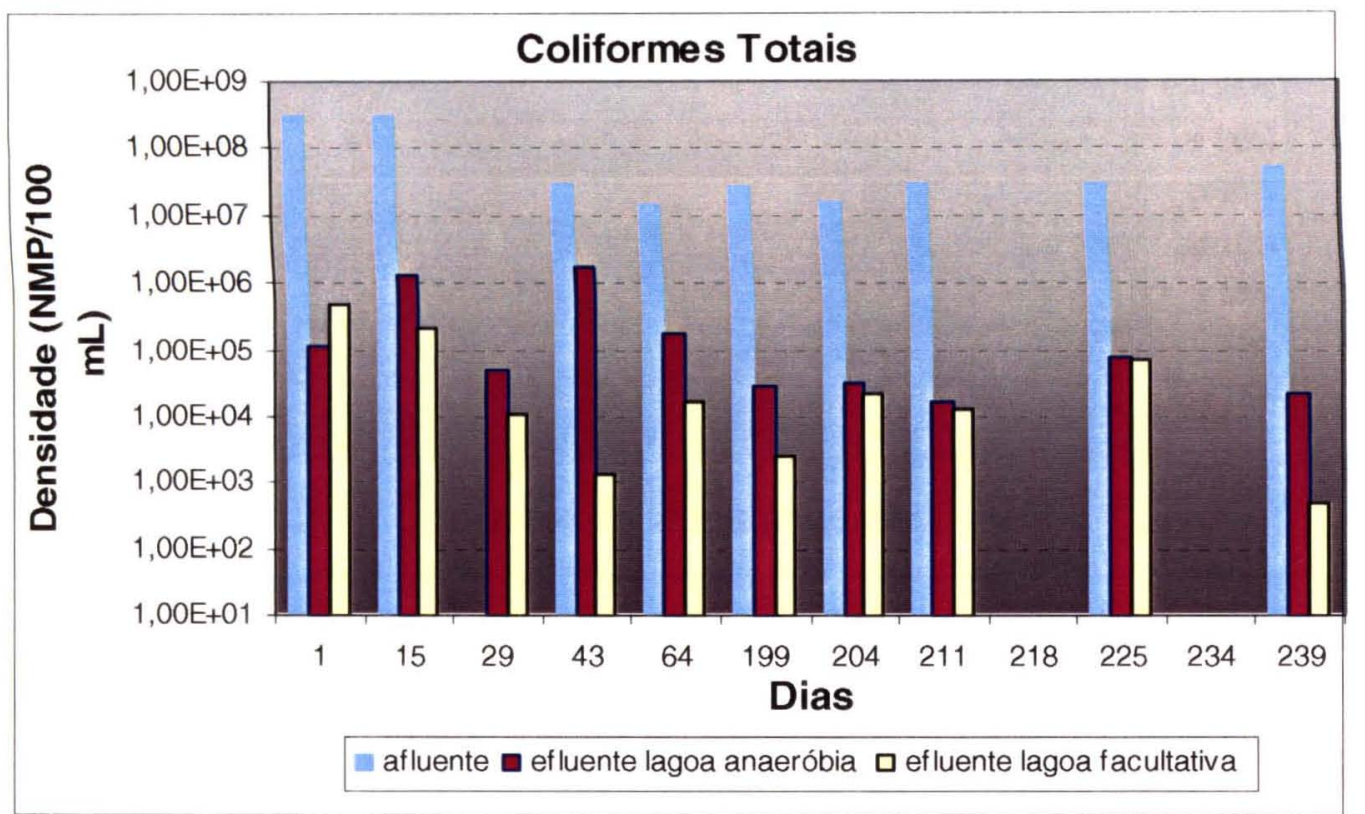

Figura 7.21 Densidade de coliformes totais do esgoto à entrada e à saída das lagoas anaeróbia e facultativa.

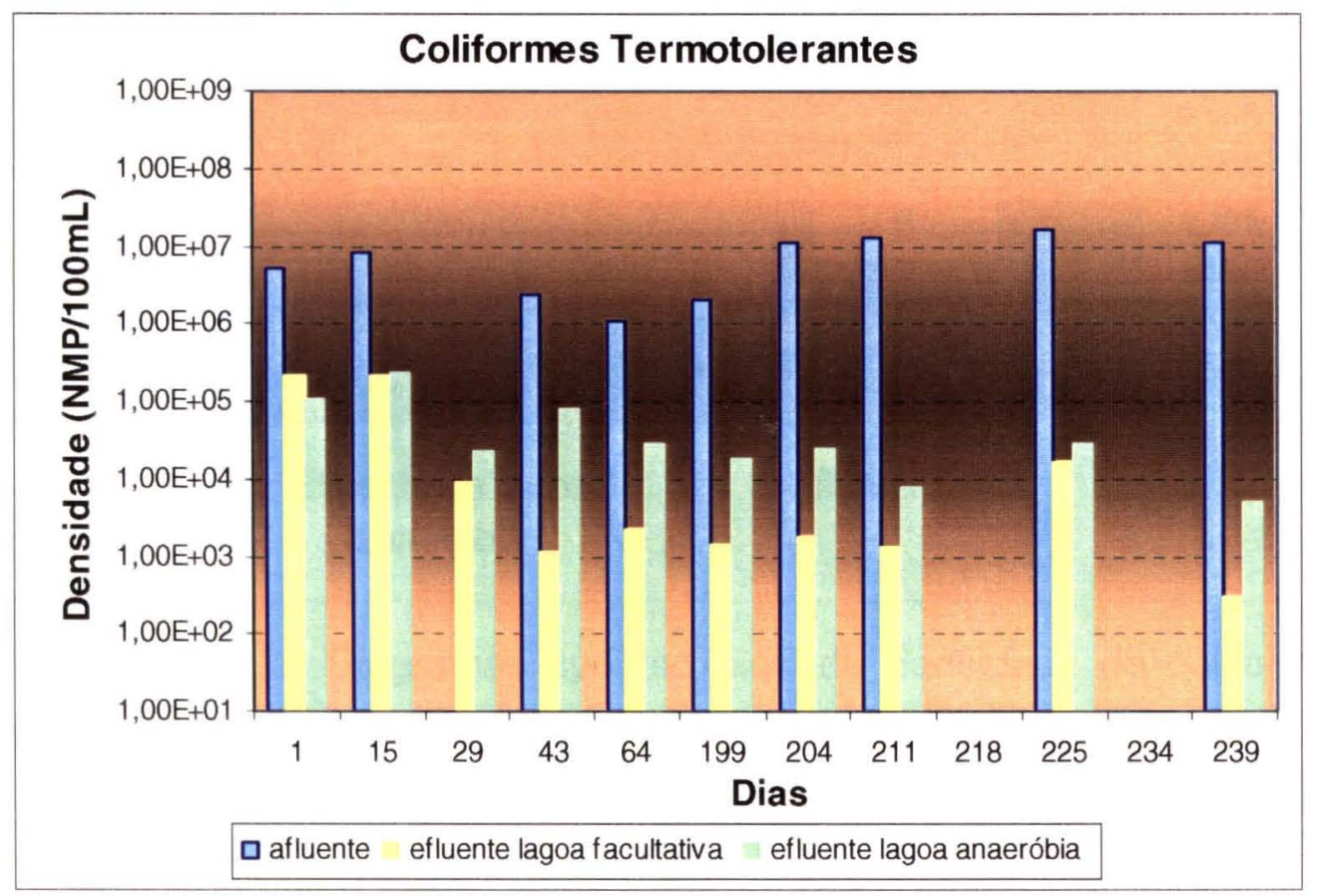

Figura 7.22 Densidade de coliformes termotolerantes do esgoto à entrada e à saída das lagoas anaeróbia e facultativa. 


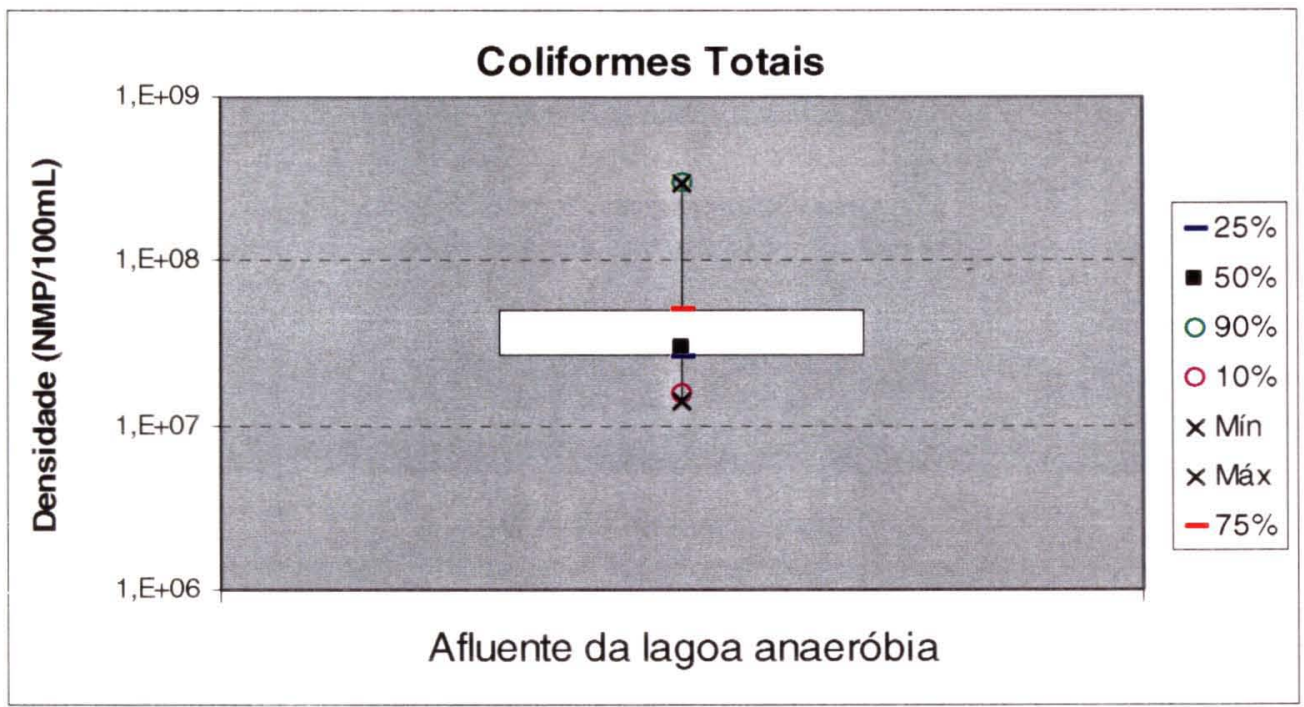

Figura 7.23 Diagramas tipo "boxplot" da densidade de coliformes totais do esgoto à entrada da lagoa anaeróbia.

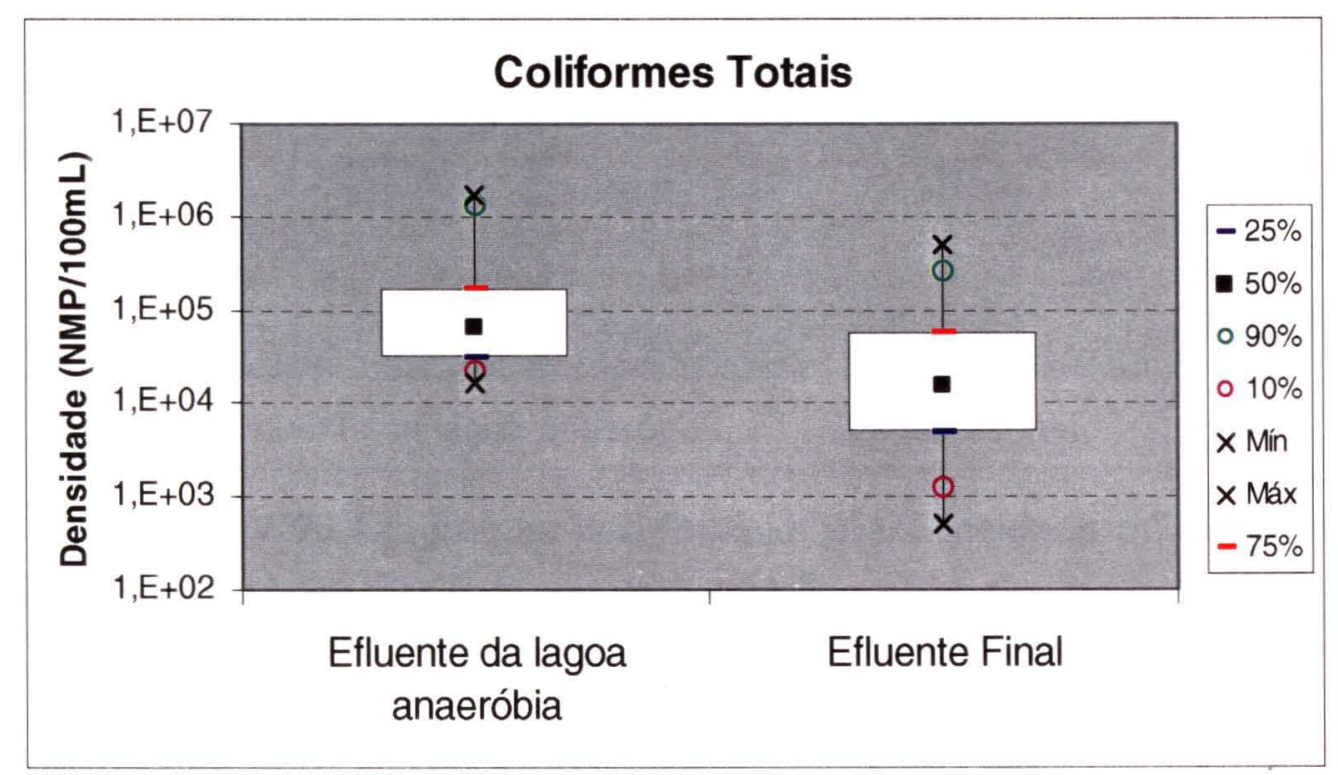

Figura 7.24 Diagramas tipo "boxplot" da densidade de coliformes totais do esgoto à saída das lagoas anaeróbia e facultativa. 


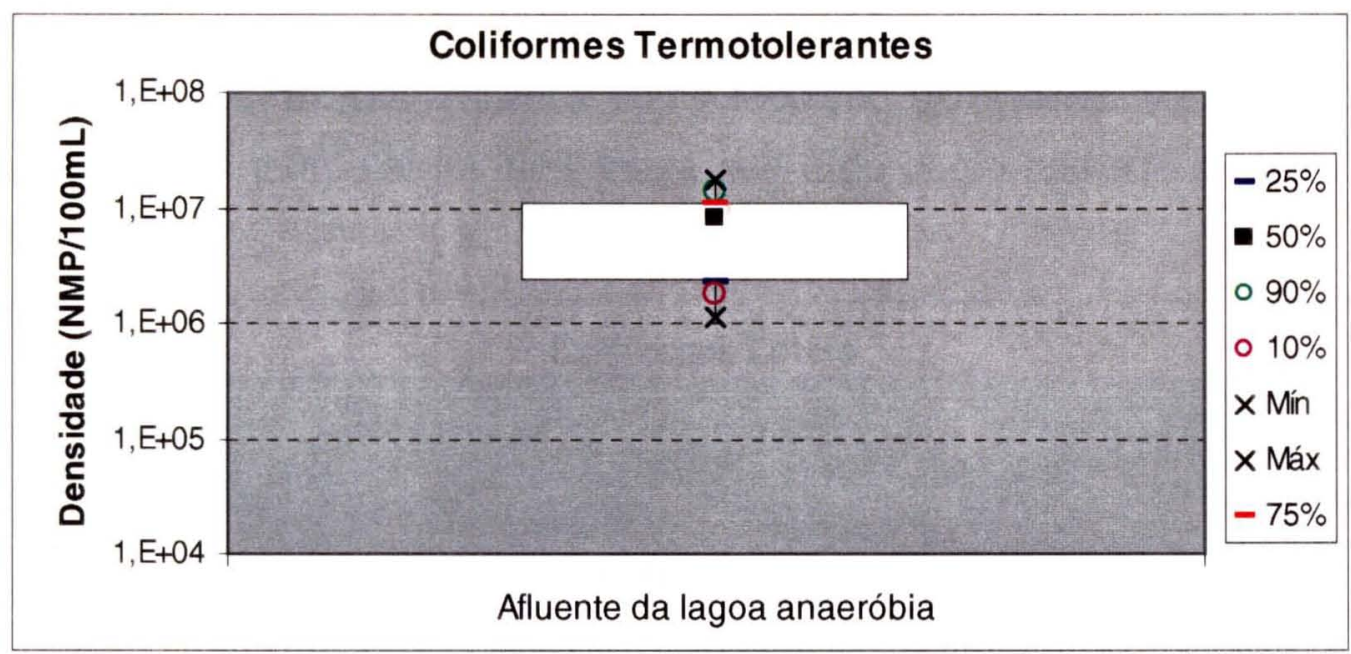

Figura 7.25 Diagramas tipo "boxplot" da densidade de coliformes termotolerantes do esgoto à entrada lagoa anaeróbia.

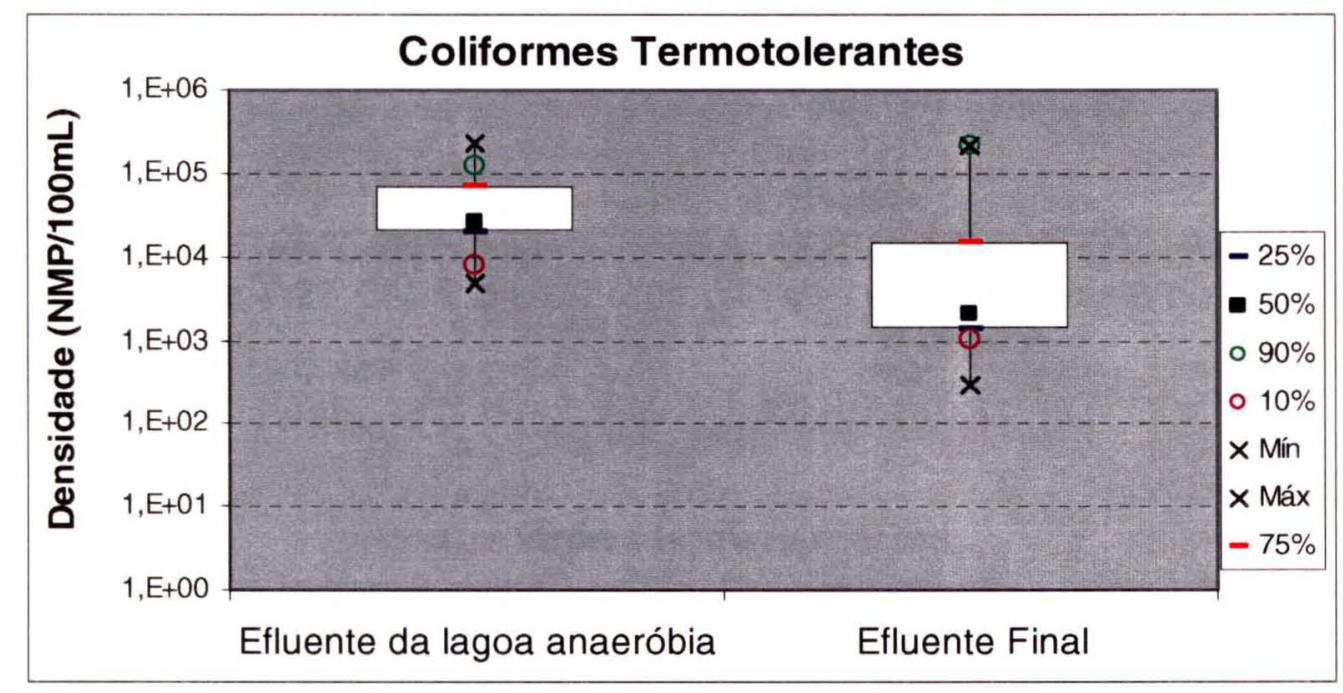

Figura 7.26 Diagramas tipo "boxplot" da densidade de coliformes termotolerantes do esgoto à saída das lagoas anaeróbia e facultativa.

Apesar da alta eficiência apresentada na remoção de patógenos (figuras 7.27 e 7.28), o efluente final apresentou ainda uma alta densidade de bactérias indicadoras de contaminação fecal, acima do permitido pelo Decreto $8468 / 76\left(<10^{3} \mathrm{NMP} / 100 \mathrm{~mL}\right)$ e CONAMA 357/05.

Conforme VON SPERLING (1996), além do processo de desinfecção utilizando cloro, ozônio, hipoclorito de sódio, entre outros, uma maior remoção de patógenos pode ser obtida ao se utilizar lagoas 
de maturação onde podem ser verificadas condições ambientais adversas aos microorganismos como radiação ultravioleta, elevado $\mathrm{pH}$, elevado OD, temperatura mais baixa que a do corpo humano e falta de nutrientes.

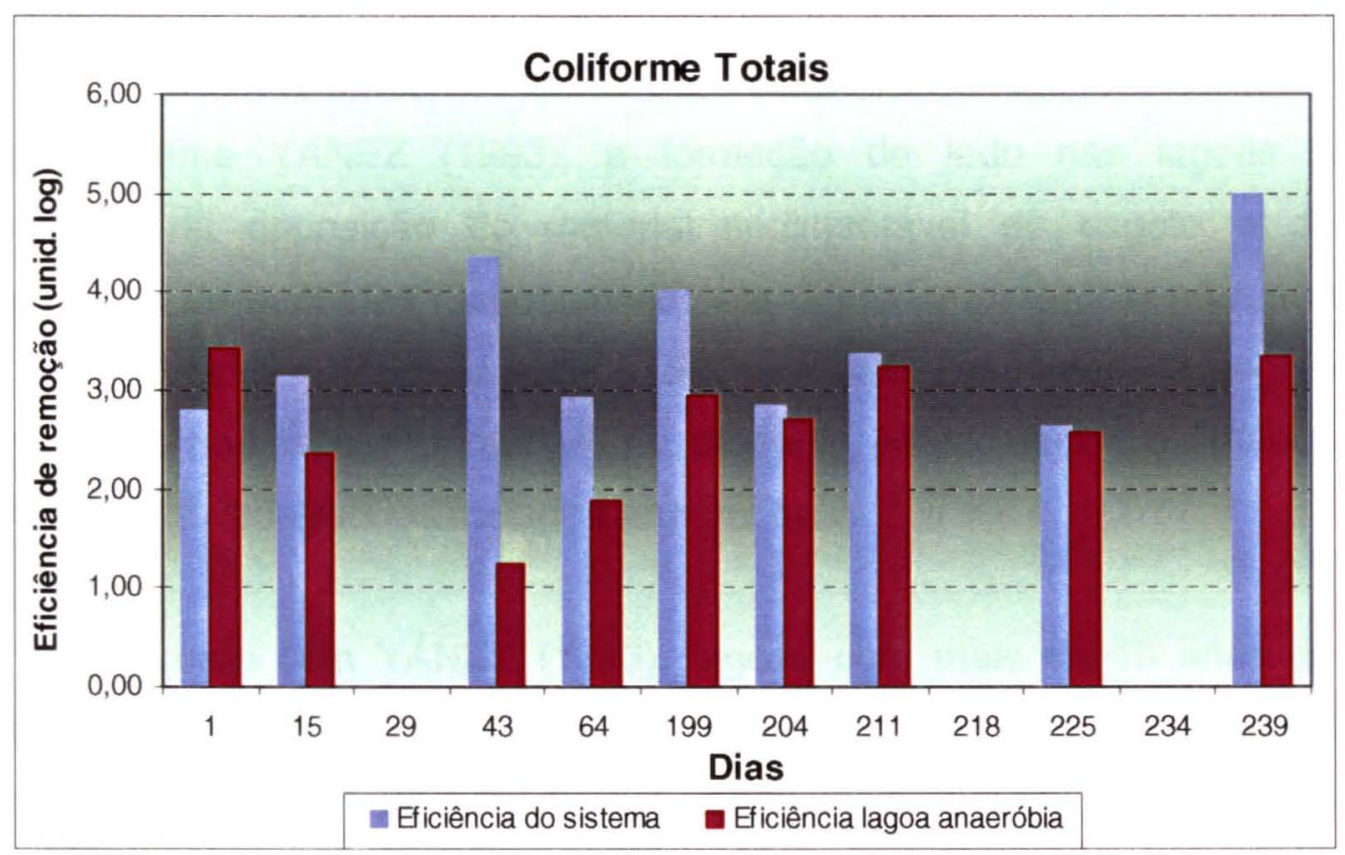

Figura 7.27 Eficiência de remoção de coliformes totais do sistema e da lagoa anaeróbia.

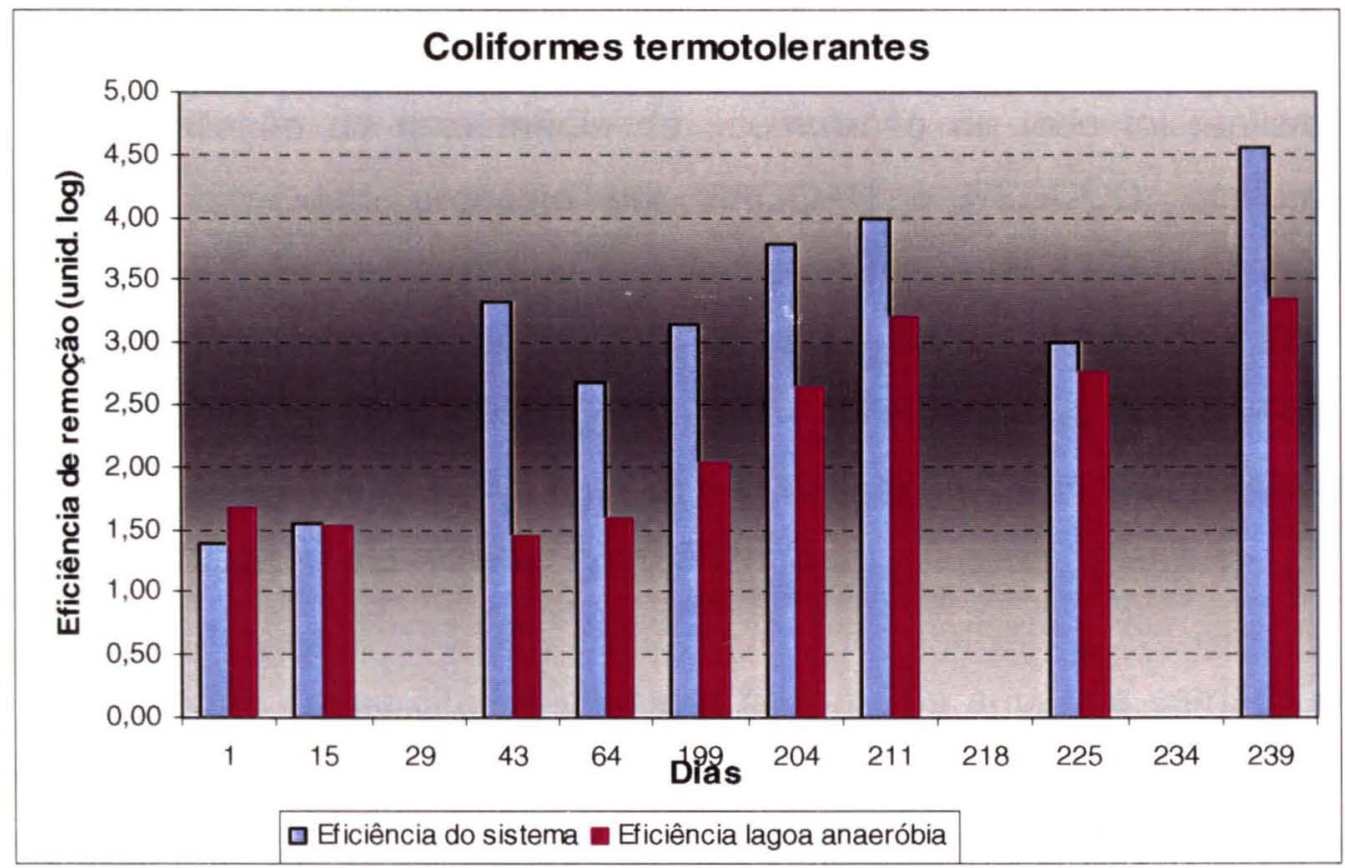

Figura 7.28 Eficiência de remoção de coliformes termotolerantes do sistema e da lagoa anaeróbia. 


\subsubsection{Estimativa da Produção de Lodo em Lagoas Anaeróbias}

A estimativa de lodos em lagoas primárias é uma etapa primordial do projeto para garantia da auto-sustentabilidade futura do empreendimento (GONÇALVES 1999).

Conforme YÁNEZ (1993), a formação de lodo nas lagoas é resultante da deposição do material sedimentável do esgoto e da reprodução de bactérias responsáveis pela digestão anaeróbia no fundo do reator. Como $100 \%$ dos sólidos sedimentáveis presentes no esgoto são retidos nas lagoas primárias, no presente estudo foram estimados produções de lodo retidos na lagoa anaeróbia.

De acordo com YÁNEZ (1993), lagoas com mais de 10 anos de operação apresentam acúmulo de lodo superior a $30 \%$ de seu volume útil e lagoas com mais de 20 anos de operação essa proporção ultrapassa os $60 \%$. Esse acúmulo reduz o volume útil da lagoa, prejudicando a eficiência do sistema. Neste Sentido, a limpeza das lagoas deve ser realizada antes que seu volume atinja $50 \%$ de seu volume útil (MARA 1976 apud ITO 2002).

A avaliação da taxa média de acumulação de lodo foi realizada utilizando o modelo proposto por SAQQAR e PESCOD, conforme equação 5.27. Ao se considerar população estimada de 4353 habitantes, carga orgânica per capita de $54 \mathrm{gDBO} / \mathrm{ha}$.d, $\mathrm{k}_{\mathrm{AS}}$ de 0,6 , vazão de 7,98 Vs e, segundo METCALF \& EDDY (2003) ao se considerar que $75 \%$ dos SST encontram-se na forma volátil e os $25 \%$ restantes na forma fixa, o volume de lodo gerado por dia resultou em $0,38 \mathrm{~m}^{3} / \mathrm{d}$.

Conforme dados citados acima, a taxa média anual da camada de lodo calculada foi de $14 \mathrm{~cm} / a n o$. Estudos realizados por SENRA (1983), mostraram taxas de acúmulo de lodo em lagoas anaeróbias na faixa de 7,3 a $15,3 \mathrm{~cm} / a n o$. SAQQAR \& PESCOD encontraram valores próximos a $46 \mathrm{~cm} / a n o$ e, MULLER (1999), após estudos nas lagoas anaeróbias de 
Eldorado e Porto de Canoa chegou a resultados de taxas de acúmulo de lodo anual próximos a $7,66 \mathrm{~cm}$ e $5,35 \mathrm{~cm}$ respectivamente.

No presente trabalho após sessões batimétricas, conforme tabela 7.3 e figura 7.29 , a lagoa anaeróbia apresentou em média uma taxa anual de acúmulo de lodo de $10 \mathrm{~cm} / \mathrm{ano}$.

Tabela 7.3 Resultado de ensaio batimétrico na lagoa anaeróbia.

\begin{tabular}{|c|c|c|c|}
\hline Distância & \multicolumn{2}{|c|}{ Ponto } & \multirow{2}{*}{\begin{tabular}{|c} 
Espessura \\
$(\mathrm{cm})$ \\
\end{tabular}} \\
\hline \multirow{2}{*}{\multicolumn{4}{|c|}{ (m) }} \\
\hline & & & \\
\hline 14,5 & $\mathrm{~S} 1 \mathrm{~A}$ & 1 & 49 \\
\hline 14,5 & $\mathrm{~S} 2 \mathrm{~A}$ & 2 & 53 \\
\hline 14,5 & S3A & 3 & 46 \\
\hline 29 & S1B & 4 & 39 \\
\hline 29 & S2B & 5 & 42 \\
\hline 29 & S3B & 6 & 37 \\
\hline 43,5 & $\mathrm{~S} 1 \mathrm{C}$ & 7 & 29 \\
\hline 43,5 & S2C & 8 & 35 \\
\hline \multirow[t]{2}{*}{43,5} & S3C & 9 & 36 \\
\hline & & Média total & 40 \\
\hline
\end{tabular}

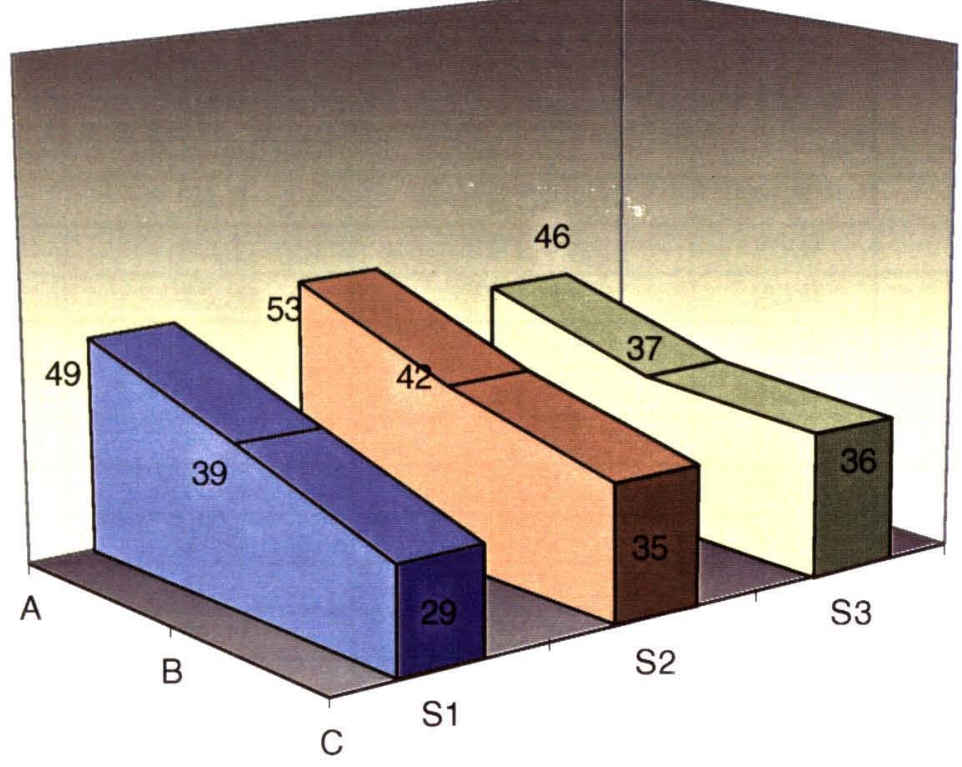

Figura 7.29 Espessura da camada de lodo na lagoa anaeróbia. 


\subsection{Balanço de massa e avaliação da produção de lodo na} ETA.

Uma vez que a produção de lodo gerado em uma ETA é função da concentração de sólidos em suspensão total presentes na água bruta, do tipo de coagulante e dosagem aplicada e, com o intuito de obter elementos que auxiliem na avaliação da disponibilidade de disposição do lodo da ETA do município de São Lourenço da Serra na ETE, foram levantadas as produções médias mensais de lodo e dosagem de coagulantes empregadas na referida ETA no período de janeiro a dezembro de 2004, conforme tabela 7.4 e figura 7.30 .

Para produção de sólidos foram utilizadas fórmulas empíricas, conforme equação 4.1 e foi considerada relação entre SS/turbidez igual a 1

Tabela 7.4 Variação da turbidez da água bruta, dosagens de coagulantes e produção de sólidos.

\begin{tabular}{|l|c|c|c|c|}
\hline Meses & Produção sólidos & Vazão Média Tratade Turbidez & Sulfato de aluminio \\
\hline & $\mathrm{kg} / \mathrm{d}$ & $\mathrm{V} / \mathrm{s}$ & $\mathrm{U} . \mathrm{T}$ & $\left(\mathrm{Al}_{2}\left(\mathrm{SO}_{4}\right)_{3}\right)$ \\
\hline & & & & $\mathrm{mg} / \mathrm{l}$ \\
\hline Janeiro & 56,2 & 21,2 & 25,0 & 54,2 \\
\hline Fevereiro & 60,1 & 21,4 & 25,0 & 60,7 \\
\hline Abril & 45,8 & 21,2 & 20,0 & 45,1 \\
\hline Maio & 35,7 & 21,5 & 15,0 & 35,4 \\
\hline Junho & 25,9 & 21,1 & 10,0 & 28,7 \\
\hline Julho & 24,9 & 20,4 & 10,0 & 28,4 \\
\hline Agosto & 16,5 & 21,7 & 5,0 & 20,4 \\
\hline Setembro & 27,8 & 22,6 & 10,0 & 28,7 \\
\hline Outubro & 46,7 & 22,0 & 20,0 & 43,5 \\
\hline Novembro & 46,6 & 20,7 & 20,0 & 48,8 \\
\hline Dezembro & 57,8 & 20,8 & 25,0 & 59,5 \\
\hline
\end{tabular}




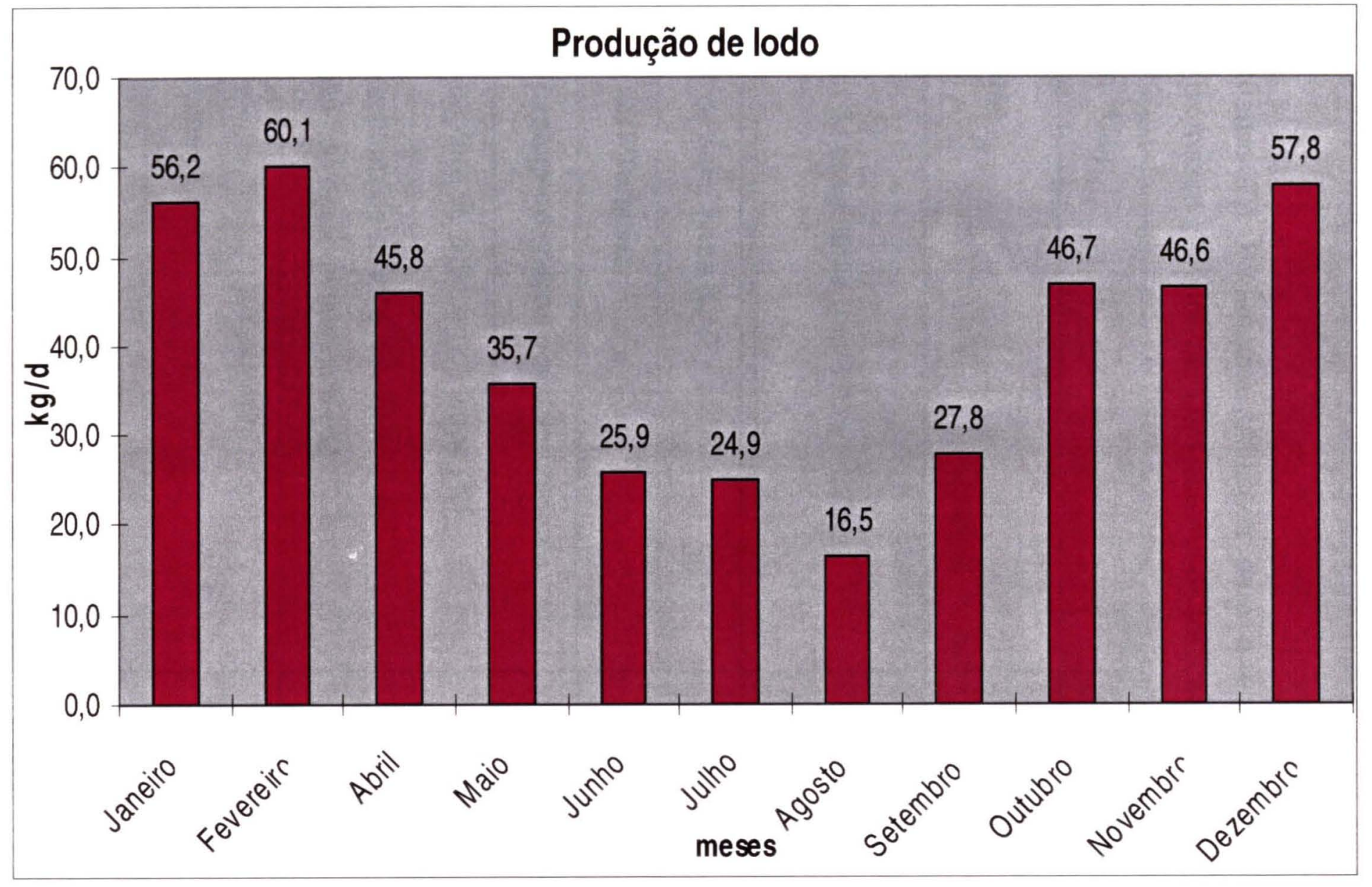

Fiqura 7.30 Produção média mensal de sólidos. 
Com o objetivo de fixar parâmetros para execução do balanço de massa da ETA (figura 7.31) e, considerando como crítico os meses de Dezembro a Fevereiro, os cálculos foram direcionados para situação do mês mais desfavorável, conseqũentemente com maior produção de lodo (fevereiro de 2004), apresentados no quadro 7.1.

Quadro 7.1 Parâmetros utilizados para a elaboração de um balanço de massa genérico para um sistema de tratamento de água.

\begin{tabular}{l|c}
\hline Vazão (m³/dia) & $1.116,00$ \\
\hline Coagulante & $\begin{array}{c}\text { Sulfato de } \\
\text { alumínio }\end{array}$ \\
\hline Dosagem de coagulante (mg/l) Alta turbidez & $\begin{array}{c}60,7 \text { expresso } \\
\text { como } \\
\mathrm{Al}_{2}\left(\mathrm{SO}_{4}\right)_{3} .14 \mathrm{H}_{2} \mathrm{O}\end{array}$ \\
\hline Turbidez da água bruta (UNT) & 25 \\
\hline Relação SST/Turbidez & 1,0 \\
\hline Taxa de captura de sólidos nos decantadores (\%) & 90 \\
\hline Taxa de captura de sólidos nos filtros (\%) & 100 \\
\hline $\begin{array}{l}\text { Taxa de captura de sólidos no sistema de } \\
\text { equalização de água de lavagem (\%) }\end{array}$ & 0 \\
\hline $\begin{array}{l}\text { Teor de sólidos no lodo proveniente dos } \\
\text { decantadores (\%) }\end{array}$ & 0,5 \\
\hline $\begin{array}{l}\text { Massa específica do lodo proveniente dos } \\
\text { decantadores (kg/m }{ }^{3} \text { ) }\end{array}$ & 1.000 \\
\hline
\end{tabular}




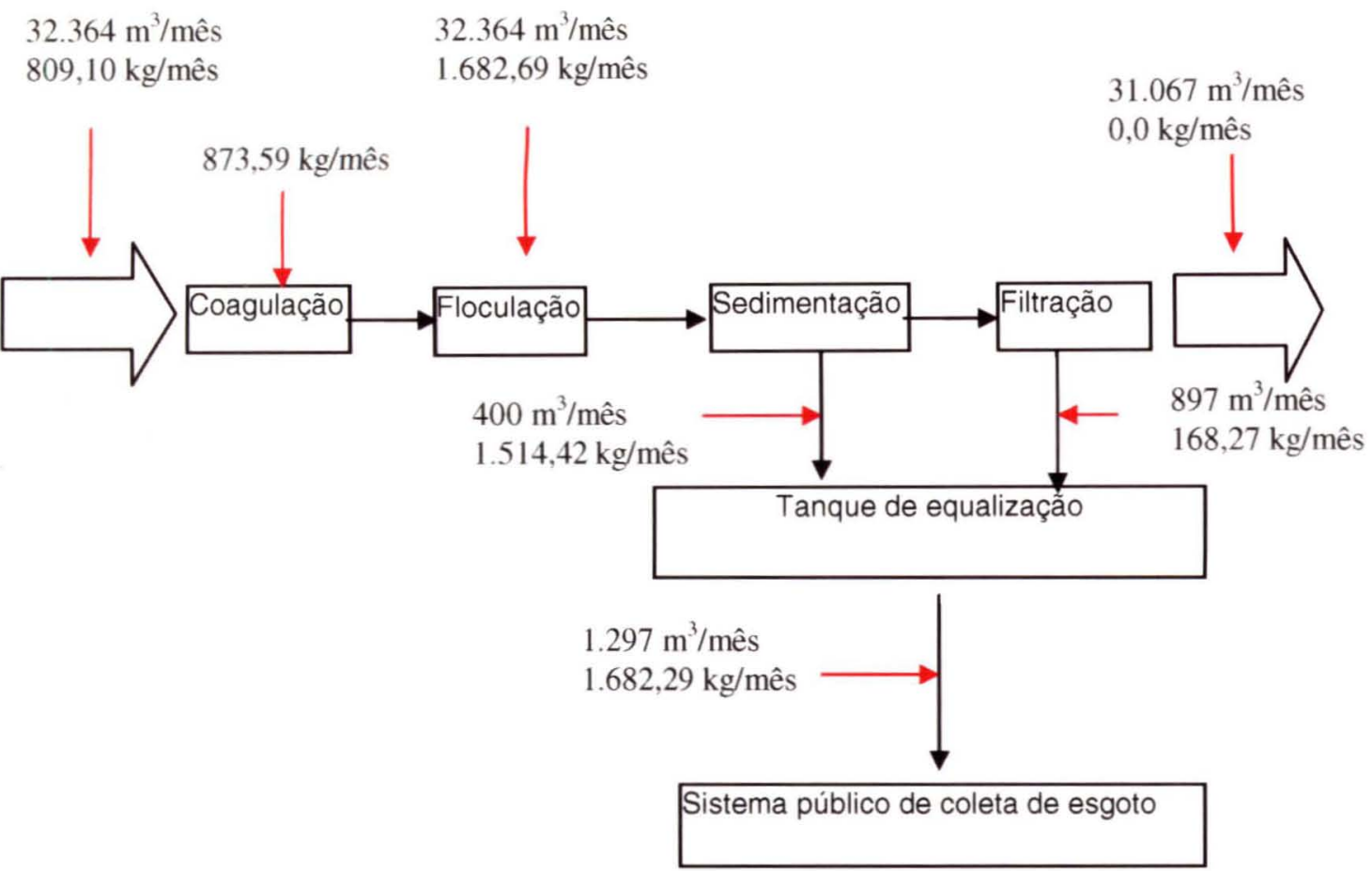

Figura 7.31 Balanço de massa da ETA (São Lourenço da Serra).

\subsection{Resultados das características físico-químicas e bacteriológicas do esgoto bruto e efluente das lagoas anaeróbia e facultativa (segunda fase).}

$\mathrm{Na}$ segunda fase, foram avaliados os resultados dos parâmetros físico-químicos, bacteriológicos e hidrobiológicos e possíveis interferências que poderão ocorrer na ETE após receber os resíduos da ETA que utiliza sulfato de alumínio como coagulante primário.

Na tabela 7.5 são apresentados os valores mínimos, médios e máximos dos parâmetros analisados na fase 2 , durante o período de 24/04/2005 à 1/08/2005, operando com vazão média de 8,5 I/s. 
Tabela 7.5 Valores mínimos, médios e máximos das variáveis analisadas durante monitoramento da ETE.

\begin{tabular}{|c|c|c|c|c|c|c|c|c|c|}
\hline Pontos & aluent & elaga an & eróbia & Eluente & - lagpa ane & eróbia & Eluente & da lagoa fa & cultativa \\
\hline & Mrimo & Medo & Meximo & Mirimo & Médo & Mtodmo & Minimo & Mádo & Madimo \\
\hline pH & 6,0 & 6,5 & 7,0 & 6,5 & 7,0 & 8,0 & 6,5 & 6,9 & $\overline{7,5}$ \\
\hline Temp a 109 & 15 & 19 & $\overline{\mathbf{3}}$ & 15 & 19 & $\mathbf{2 3}$ & 15 & 19 & $2 \mathbf{3}$ \\
\hline Terpe fga (oO) & 17 & 20 & 24 & 16 & 20 & 24 & 16 & 19 & $\overline{\mathbf{Z 3}}$ \\
\hline DBOSd(mgL) & 189 & 308 & $\overline{391}$ & $\mathbf{2 8}$ & 48 & 7 & 23 & 34 & 44 \\
\hline DBOSd illoede(mg/) & 70 & 138 & 193 & 3 & 11 & 22 & 5 & 9 & 14 \\
\hline$D \infty O(m g /)$ & 350 & 517 & 820 & 117 & 235 & 600 & 9 & 172 & 52 \\
\hline Donfftuada(mol) & 155 & 251 & 528 & 34 & 79 & 189 & $\overline{\mathbf{2 3}}$ & 64 & 170 \\
\hline Nuogfriotatal Kaechal & 36,4 & 5,2 & 113,4 & 15,4 & $\overline{\mathbf{9 , 4}}$ & 70,0 & 14,0 & $\overline{365}$ & 81,2 \\
\hline Nitrogenio Amoriac. & 15,7 & 35,1 & 51,5 & 9,2 & 24,3 & 44,8 & 8,4 & 226 & 426 \\
\hline Fóstoro Tada & 4,1 & 6,4 & 9,0 & 2,0 & 3,7 & 7,0 & 2,3 & 3,3 & 6,8 \\
\hline Ototostato & $\overline{3,4}$ & 4,5 & 6,0 & $\overline{1,1}$ & 2,2 & 4,1 & 1,2 & 2,1 & 4,0 \\
\hline ST (mgl) & 4 & 644 & 1114 & 152 & 331 & 397 & 308 & 349 & 411 \\
\hline SF (mgl) & 245 & 359 & 538 & 53 & 155 & 22 & 96 & 175 & 240 \\
\hline SV (mg) & 176 & 305 & $5 / 6$ & $\mathscr{9}$ & 176 & 365 & 136 & 174 & 315 \\
\hline SST (mgL) & 79 & 243 & 621 & 56 & 102 & 253 & 56 & 88 & 165 \\
\hline SSF (mg) & 27 & 79 & 253 & 7 & 15 & 32 & 1 & 15 & 43 \\
\hline SSV (mpL) & 52 & 163 & 368 & 46 & 86 & 223 & 51 & 73 & 130 \\
\hline Solidos secimentás & $\overline{1,5}$ & 44 & 15,0 & $\$, 1$ & 0,1 & $\overline{Q 1}$ & Q,1 & $<0,1$ & 8,1 \\
\hline Cota's & $1, \pi \bar{E}+07$ & $5,22 E+07$ & $1,30 \mathrm{E}+08$ & $1,40 E+05$ & $6,34 E+05$ & $1,70 E+06$ & $2,30 E+04$ & $2,00 E+05$ & $7,00 E+05$ \\
\hline Qemotiderantes & $5,00 E+06$ & $1,2 E+07$ & $3,00 E+07$ & $5,00 E+04$ & $1,525+05$ & $3,00 E+05$ & $1,30 E+04$ & $5,80 E+04$ & $2,20 E+05$ \\
\hline
\end{tabular}

\subsubsection{Temperatura}

Variações de temperatura são parte integrante do regime climático normal e, a temperatura superficial do líquido é influenciada por fatores como altitude, latitude, estação do ano período do dia, etc. Geralmente a elevação de temperatura de um corpo d'água é influenciada por despejos industrias (CETESB 2003). No presente trabalho, na segunda fase, assim como na primeira, a temperatura do esgoto bruto e do efluente das lagoas anaeróbias e facultativas se mantiveram em uma faixa de 19 a $22{ }^{\circ} \mathrm{C}$, bem inferiores aos exigidos tanto pelo Decreto 8468/76 (SP) quanto pelo CONAMA 357/05.

\subsubsection{Potencial hidrogeniônico (pH)}

Conforme RICHTER (2001), o lodo gerado a partir de sulfato de alumínio apresenta características gelatinosas, cuja fração de sólidos é constituída de hidróxido de alumínio, partículas inorgânicas, colóides de cor e outros resíduos orgânicos removido no processo de coagulação. 
Esse material apresenta ainda pequena proporção de biodegradáveis e valores de $\mathrm{pH}$ próximo ao neutro.

Durante o monitoramento $\mathrm{pH}$ se manteve próximo ao valor neutro $(7,0)$, semelhante ao encontrado na primeira fase de estudo. Dessa forma, o lançamento do lodo nas redes coletoras não apresentou até o presente momento interferências em relação a esse parâmetro. Sendo assim, o pH do esgoto bruto e do efluente das lagoas anaeróbia e facultativa se manteve na faixa de $\mathrm{pH}$ estabelecida para os padrões de lançamento de efluentes em corpos receptores, tanto de acordo com a legislação federal como pela legislação do Estado de São Paulo.

\subsubsection{Demanda bioquímica de oxigênio (DBO)}

Nas figuras 7.32 a 7.34 podem ser observados que as concentrações de $\mathrm{DBO}_{5,20}$ no esgoto bruto e no efluente da lagoa anaeróbia e facultativa não apresentaram em média variações significativas quando comparadas à primeira fase. As concentrações médias nesta fase apresentaram os seguintes valores respectivamente, 308 mg/L, 48mg/L e 34mg/L.

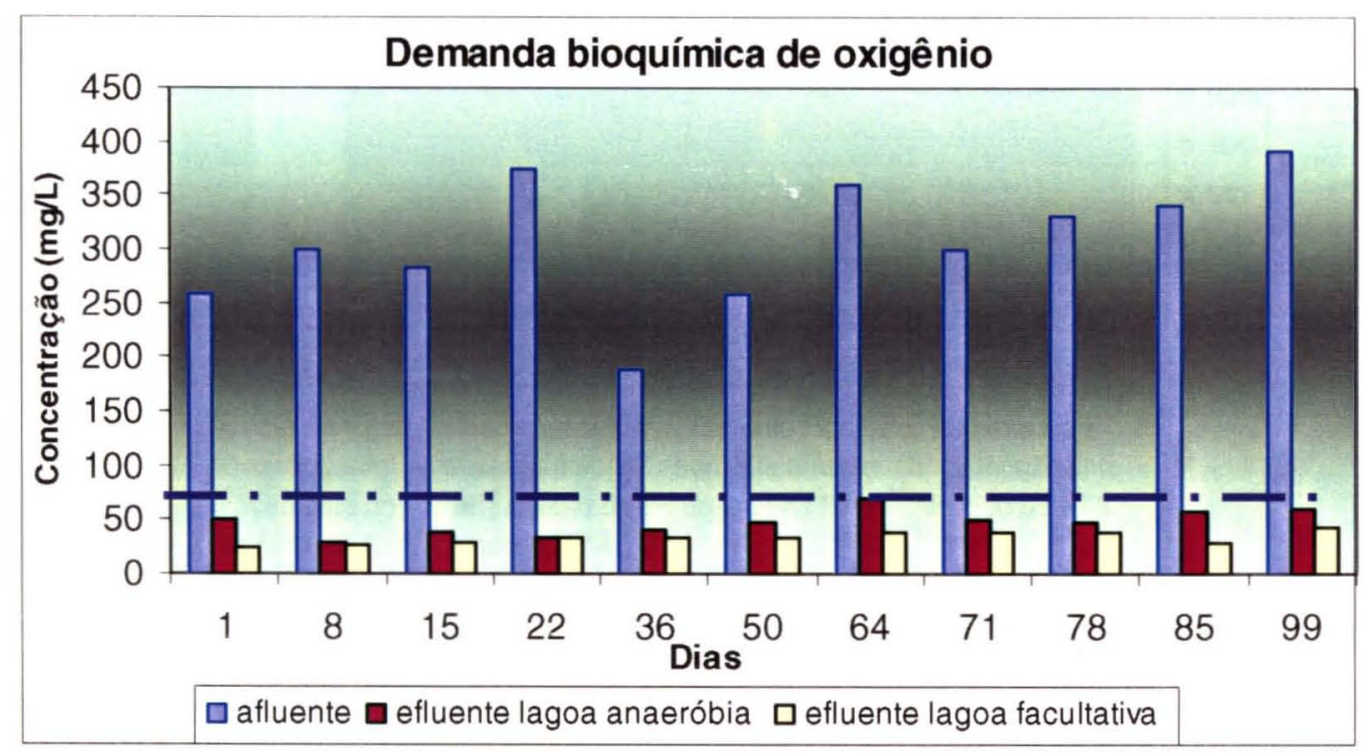

Figura 7.32 Concentração de DBO do esgoto à entrada e à saída das lagoas anaeróbia e facultativa. 


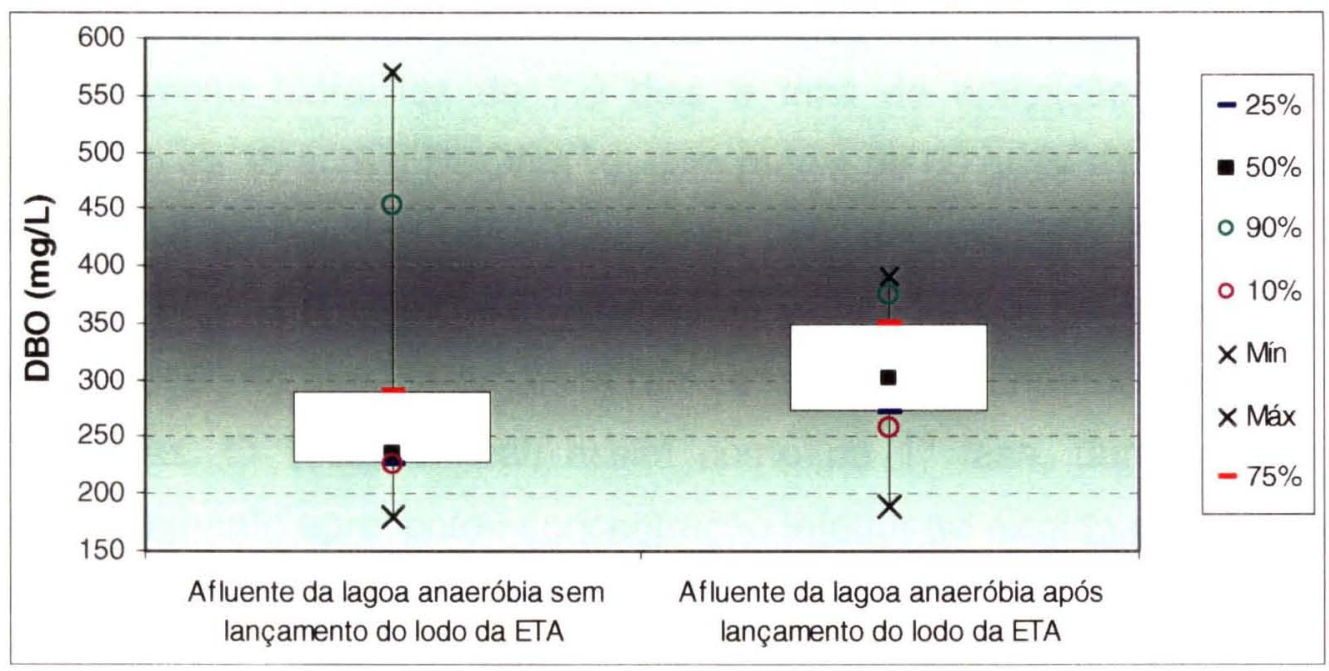

Figura 7.33 Diagramas tipo "boxplot" da concentração de DBO do esgoto à entrada da lagoa anaeróbia.

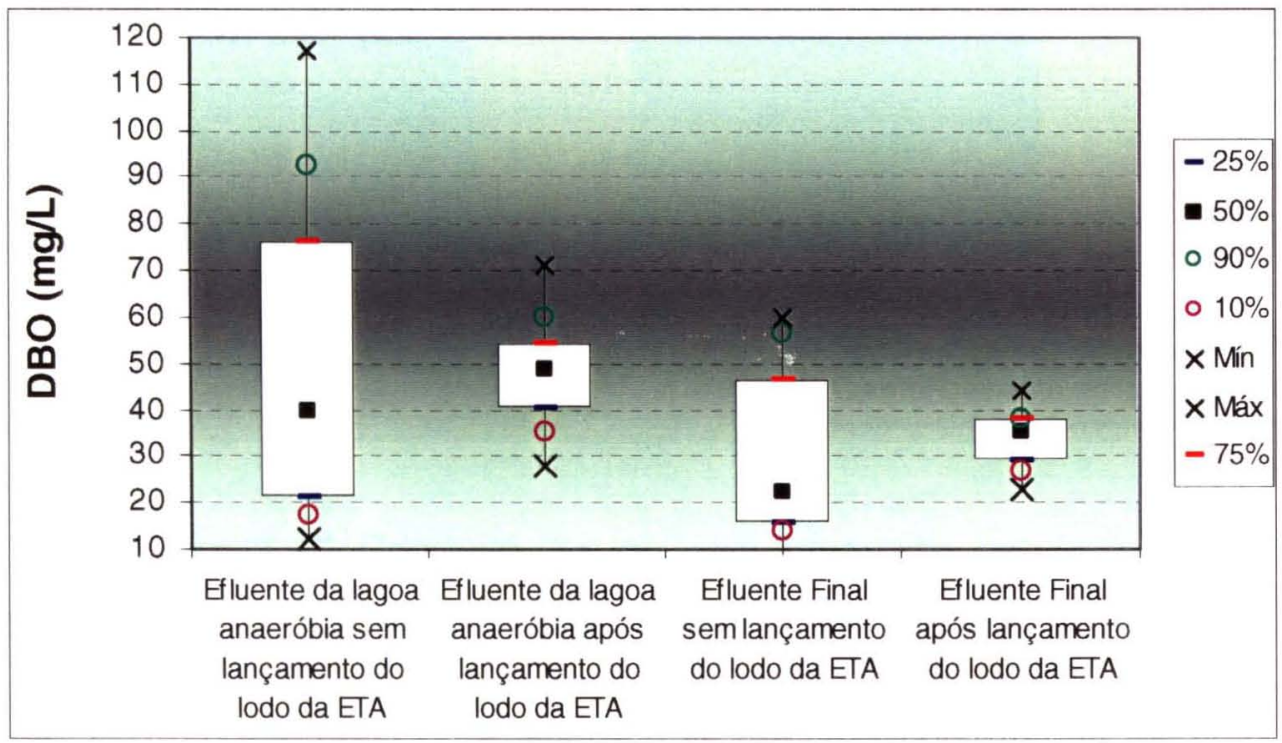

Figura 7.34 Diagramas tipo "boxplot" da concentração de DBO do esgoto à saída das lagoas anaeróbia e facultativa. 
Ao se comparar a $1^{\text {a }}$ fase e a $2^{a}$ fase (figura 7.35 ) pode ser observada que as eficiências do sistema e da lagoa anaeróbia também não apresentaram variações significativas. A lagoa anaeróbia nesta fase da pesquisa apresentou em média uma eficiência de $88,8 \%$ com tempo de detenção hidráulica de 7,0 dias e taxa de aplicação volumétrica variando de 36 a $75 \mathrm{~g} \mathrm{DBO} / \mathrm{m}^{3}$.d, com média de $60 \mathrm{gDBO} / \mathrm{m}^{3}$.d. A lagoa facultativa apresentou nesta fase, uma taxa de aplicação superficial de $70 \mathrm{~kg} \mathrm{DBO} /$ /ha.d, valor relativamente baixo, em função da boa eficiência de remoção de matéria orgânica realizada na lagoa anaeróbia e TDH de 25,5 dias. O efluente final, assim como na $1^{\text {a }}$ fase, durante todo 0 monitoramento apresentou concentração inferior ao exigido pelo Decreto 8468/76 (60mg/L).

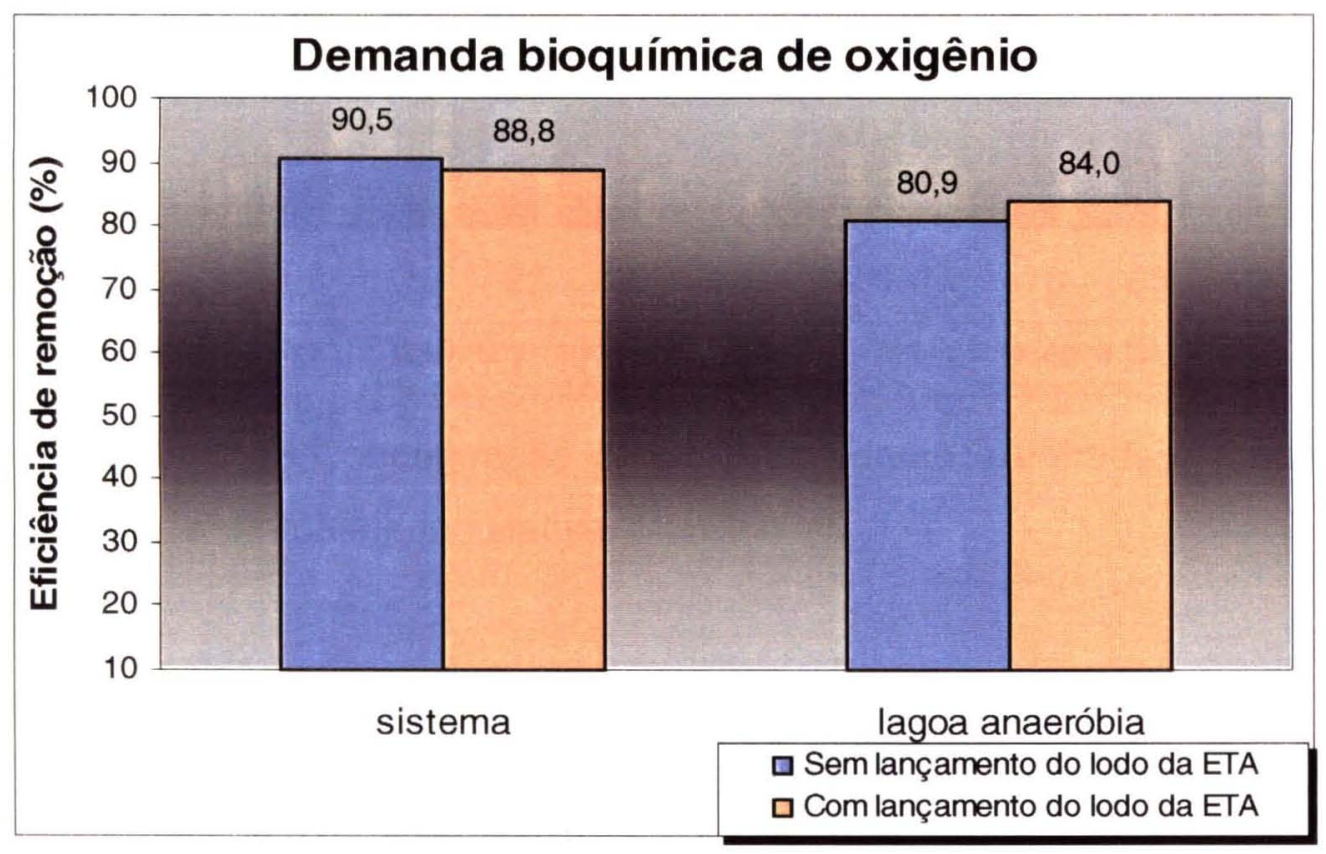

Figura 7.35 Comparação de eficiências de remoção de DBO do sistema e da lagoa anaeróbia antes e após lançamento do lodo da ETA.

\subsubsection{Demanda química de oxigênio (DQO)}

A DQO do esgoto bruto apresentou valor médio de $517 \mathrm{mg} / \mathrm{L} \mathrm{com}$ valores mínimos e máximos de 350 e $820 \mathrm{mg} / \mathrm{L}$, respectivamente. O 
efluente da lagoa anaeróbia e facultativa apresentou concentrações médias de 235 e 172 mg/L. Nesta fase do experimento, a relação DQO/DBO em média do esgoto bruto apresentou valor de 2/1 e do efluente final relação de 6/1, no efluente da lagoa anaeróbia foi observada relação de 5/1. As eficiências do sistema e da lagoa anaeróbia se mantiveram próximas às apresentadas na $1^{\text {a }}$ fase com valores de remoção respectivamente de $67,9 \%$ e 55,7\% (figuras 7.36 a 7.39 ).

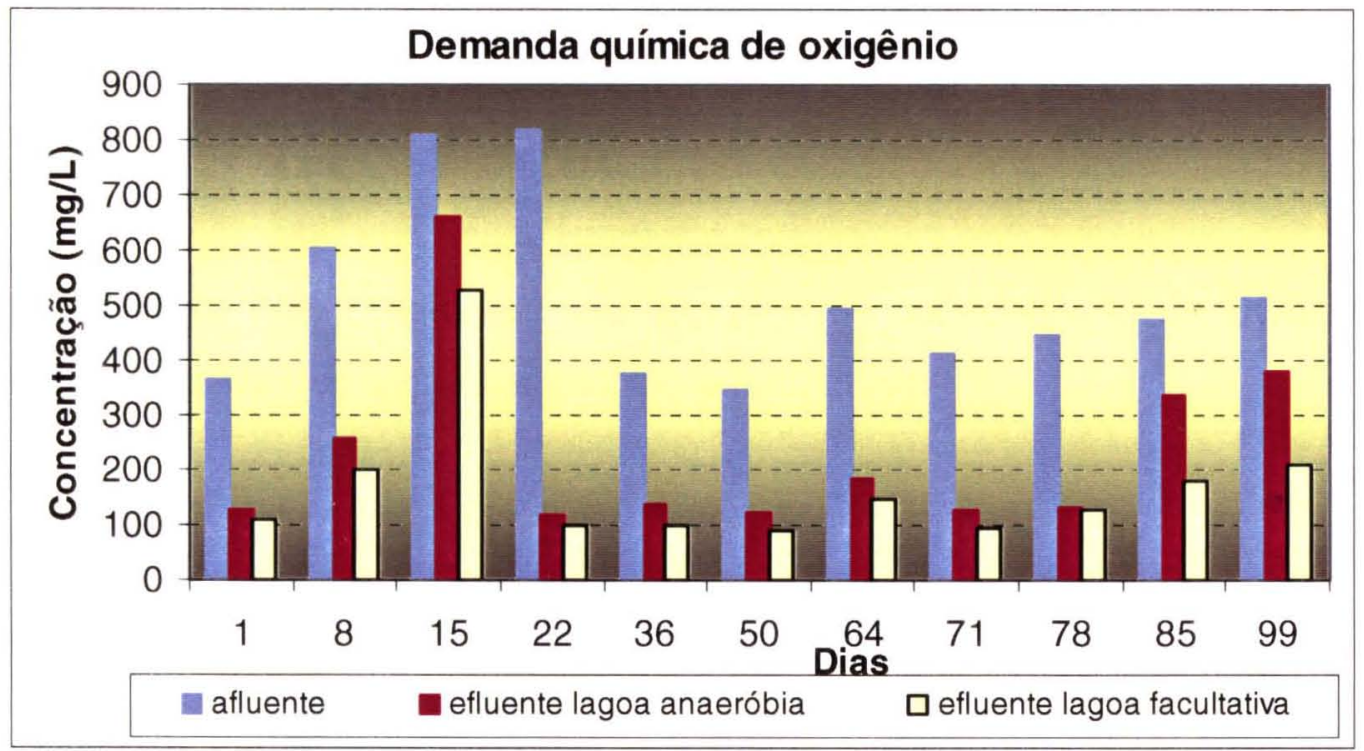

Figura 7.36 Concentração de DQO do esgoto à entrada e à saída das lagoas anaeróbia e facultativa.

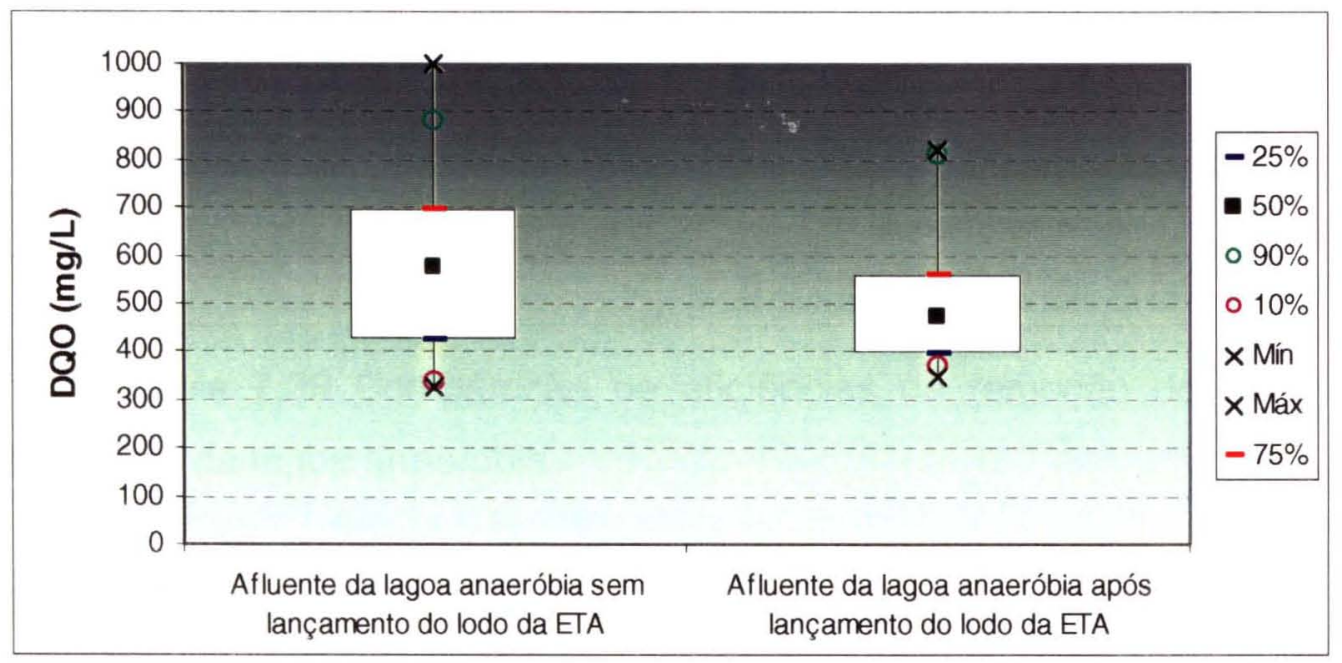

Figura 7.37 Diagramas tipo "boxplot" da concentração de DQO do esgoto à entrada da lagoa anaeróbia. 


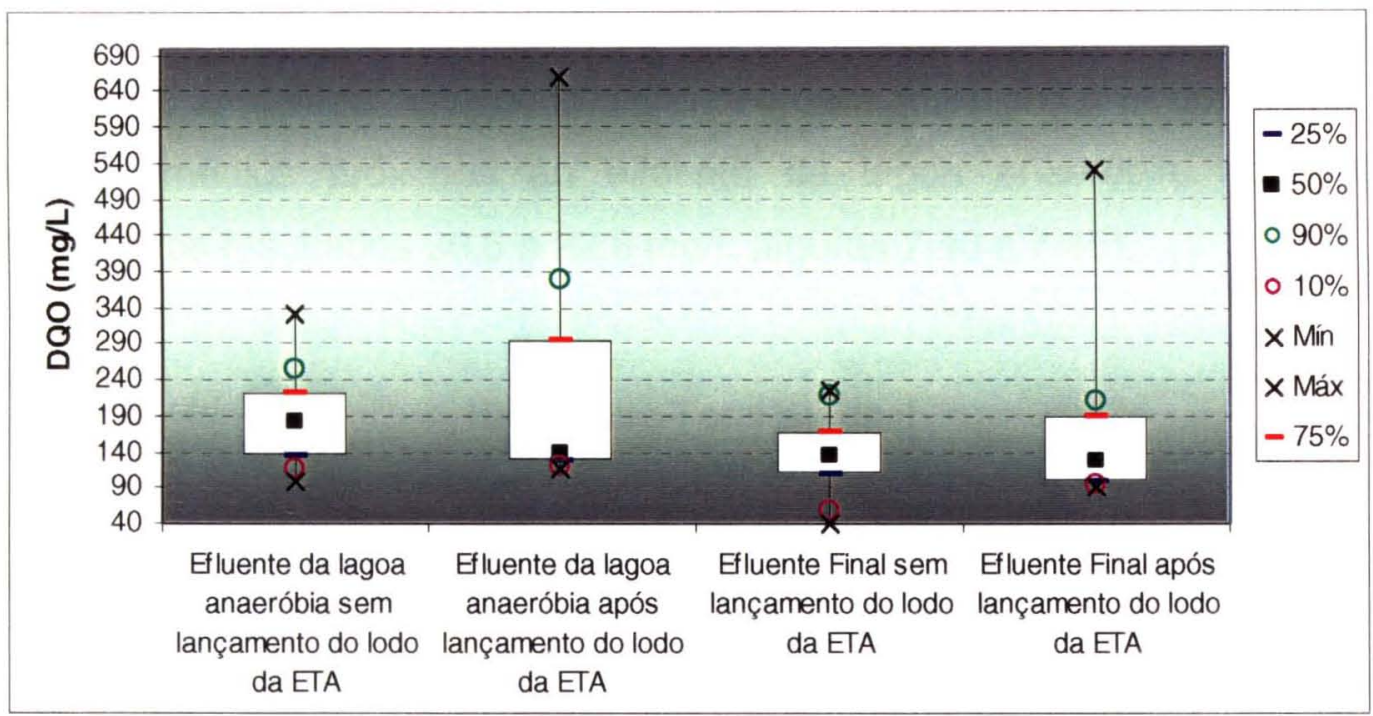

Figura 7.38 Diagramas tipo "boxplot" da concentração de DQO do esgoto à saída das lagoas anaeróbia e facultativa.

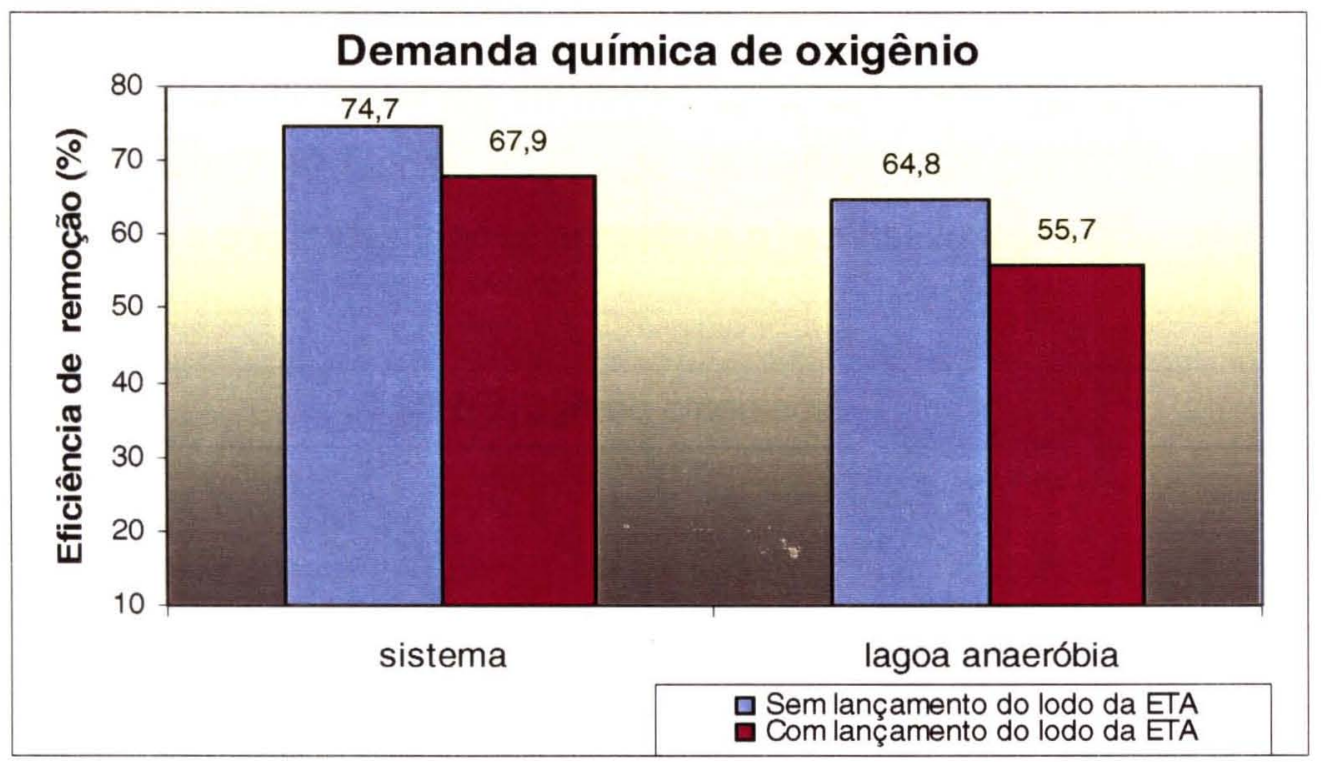

Figura 7.39 Comparação de eficiências de remoção de DQO do sistema e da lagoa anaeróbia.

\subsubsection{Nitrogênio Total Kjedhal (NKT) e Nitrogênio Amoniacal}

Nesta fase do projeto, o esgoto bruto apresentou concentrações médias de 55,2 mg/L de Nitrogênio Total Kjedhal e 35,1 mg/L de 
Nitrogênio amoniacal. O efluente da lagoa anaeróbia apresentou concentrações médias de $39,4 \mathrm{mg} / \mathrm{L}$ para NKT e $24,3 \mathrm{mg} / \mathrm{L}$ para nitrogênio amoniacal, enquanto o efluente da lagoa facultativa apresentou valores médios próximos ao efluente da lagoa anaeróbia, com os respectivos resultados 36,5 e $22,6 \mathrm{mg} / \mathrm{L}$ (figuras 7.40 a 7.45 ).

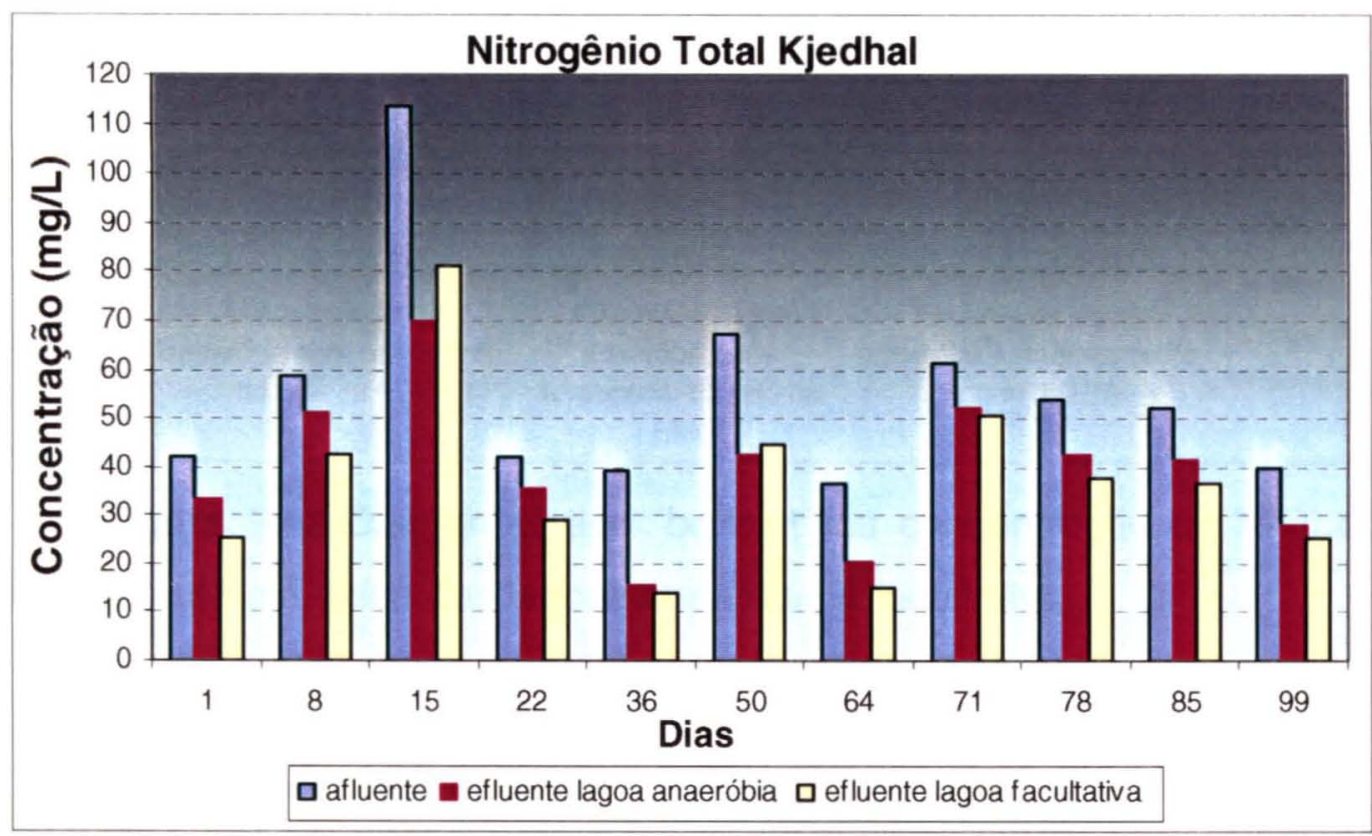

Figura 7.40 Concentração de Nitrogênio total (NKT) do esgoto à entrada e à saída das lagoas anaeróbia e facultativa.

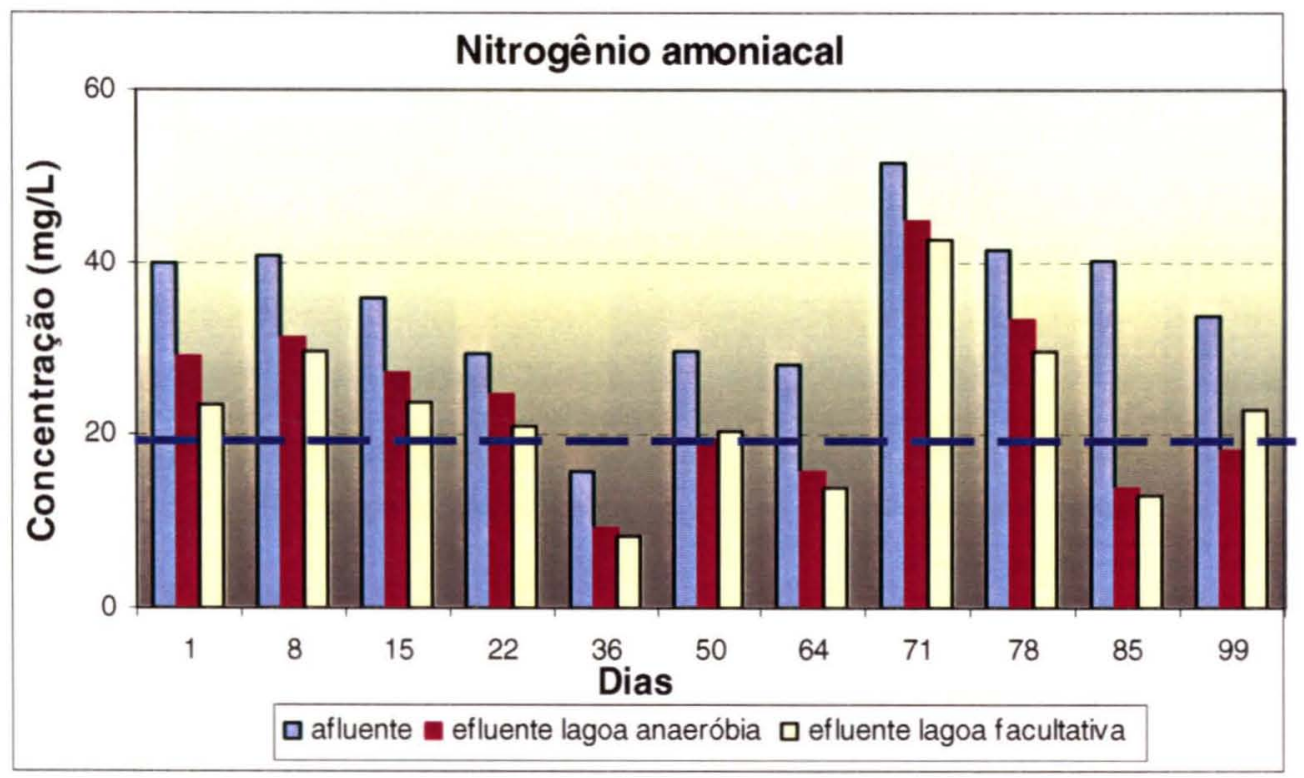

Figura 7.41 Concentração de Nitrogênio amoniacal do esgoto à entrada e à saída das lagoas anaeróbia e facultativa. 


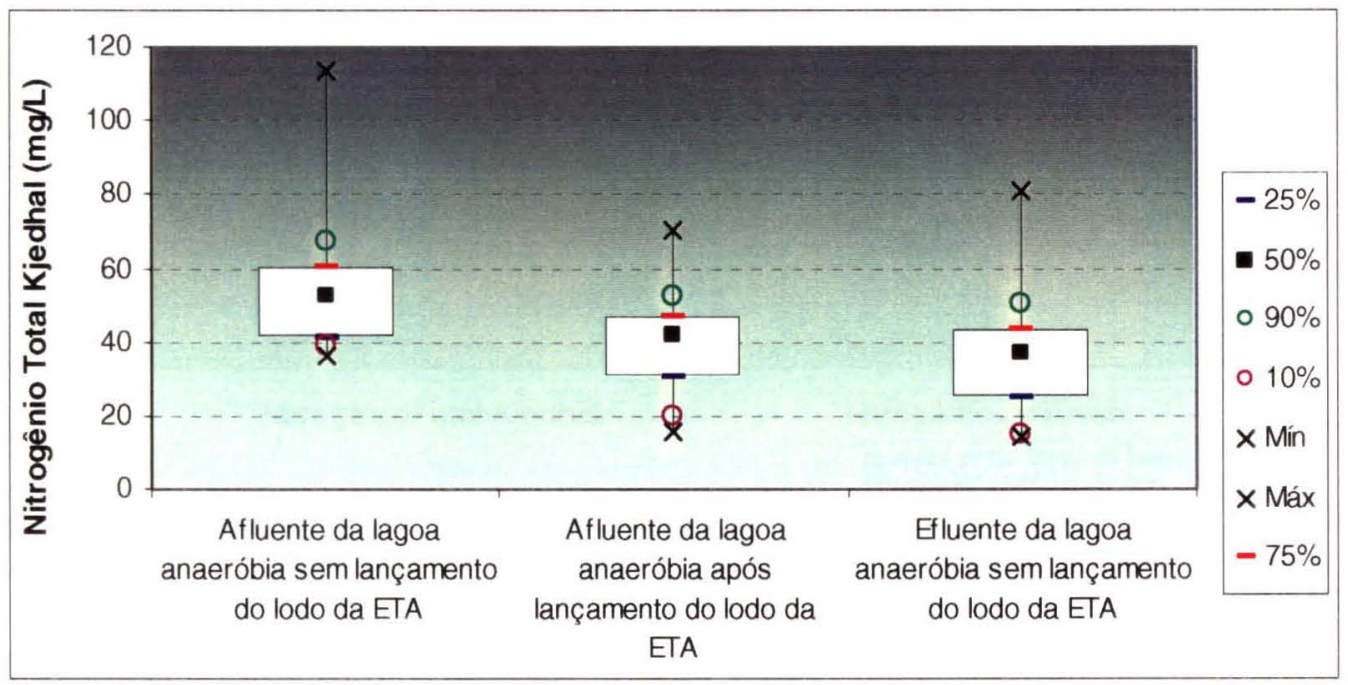

Figura 7.42 Diagramas tipo "boxplot" da concentração de NKT do esgoto bruto e à saída das lagoas anaeróbia e facultativa.

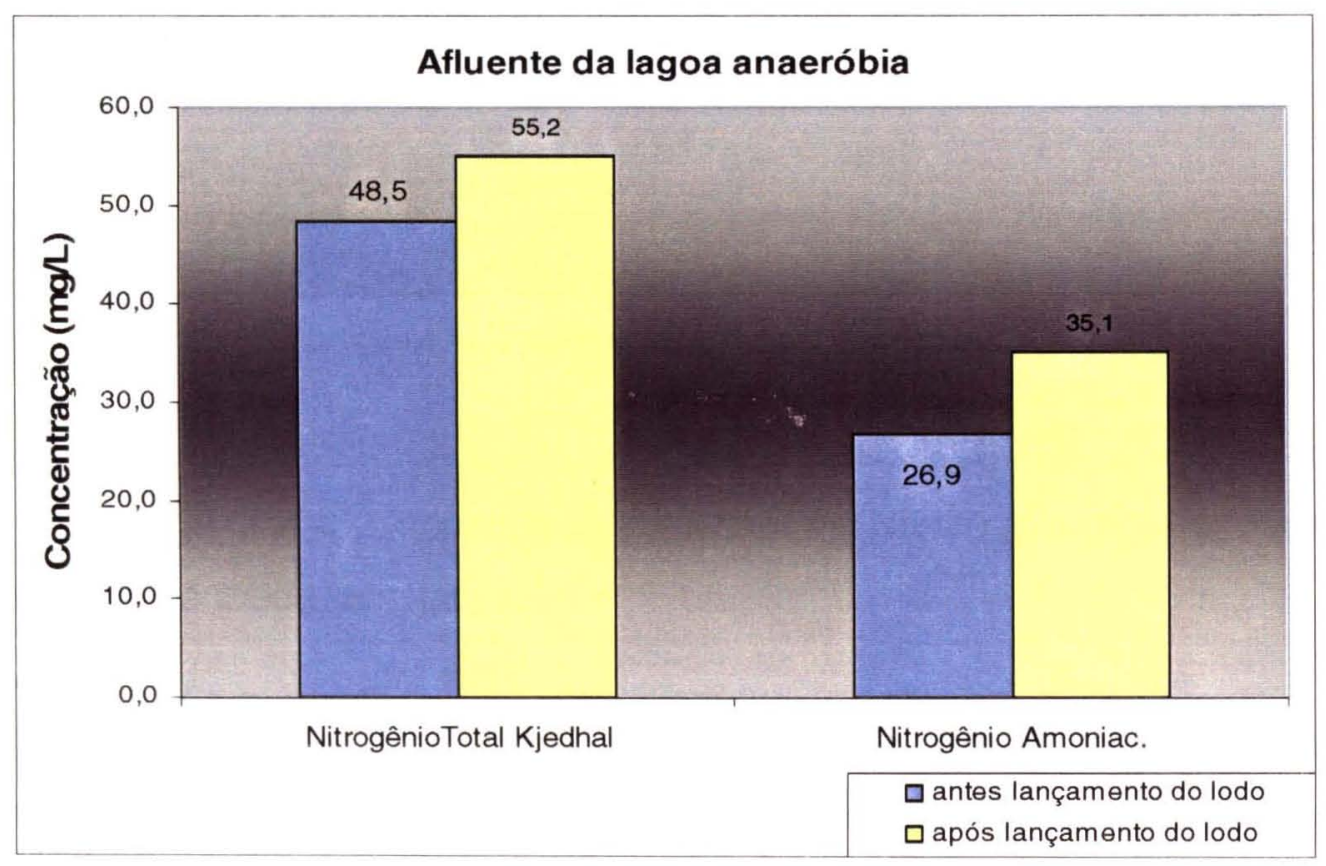

Figura 7.43 Concentrações médias de NKT e nitrogênio amoniacal à entrada da lagoa anaeróbia. 


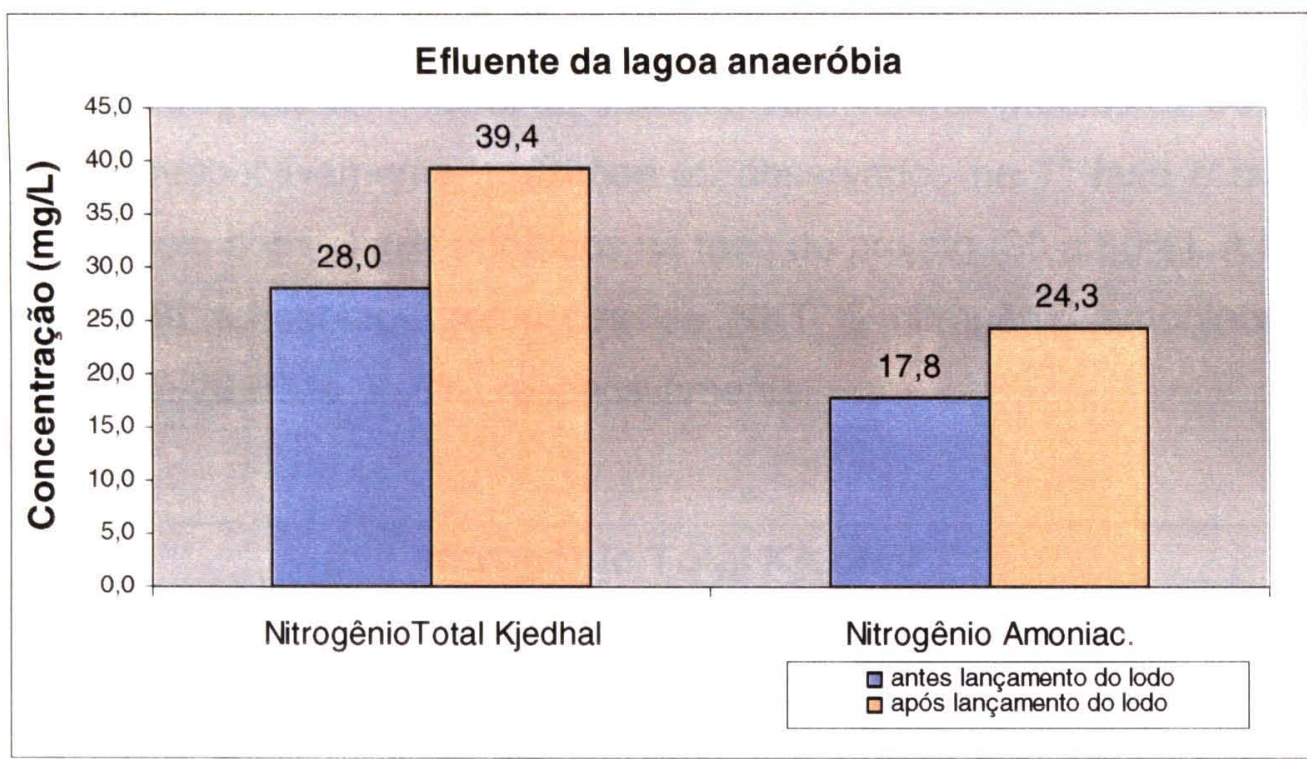

Figura 7.44 Concentrações médias de NKT e nitrogênio amoniacal à saída da lagoa anaeróbia.

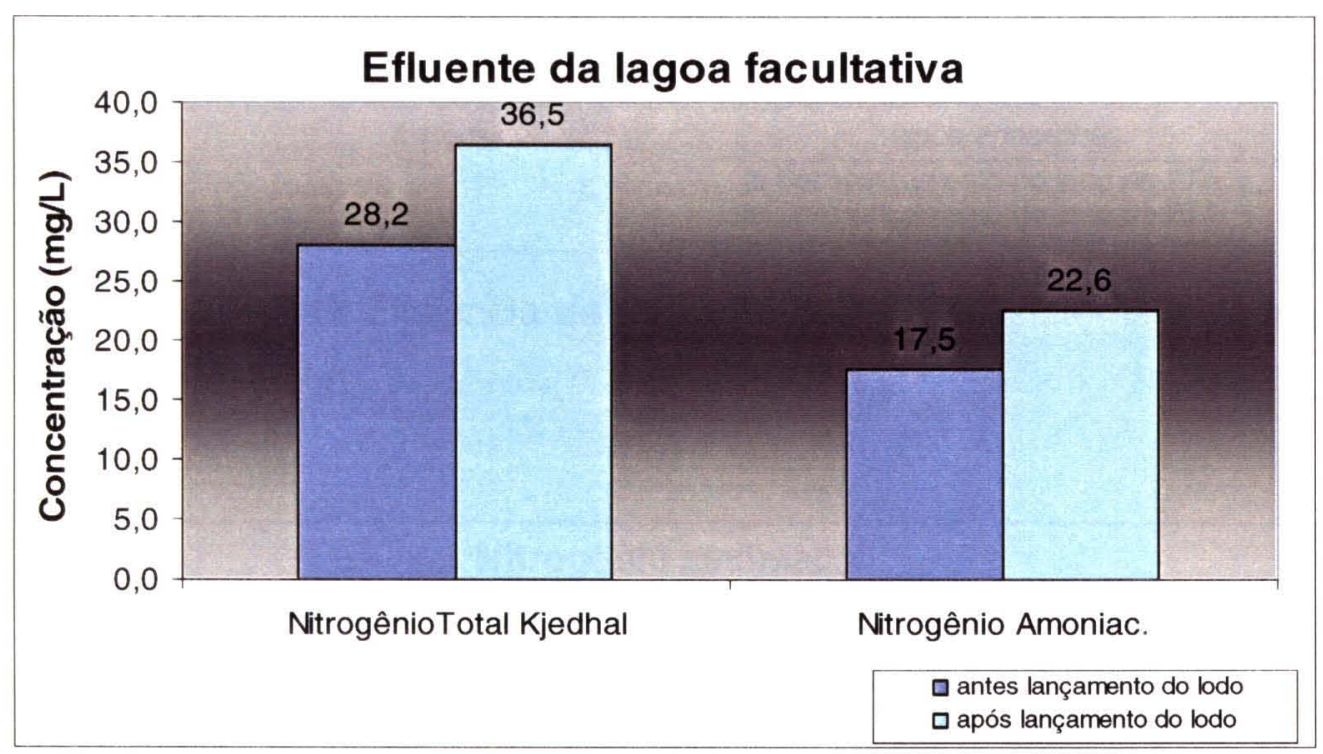

Figura 7.45 Concentrações médias de NKT e nitrogênio amoniacal à saída da lagoa facultativa.

Segundo GOMES (2002), o processo de nitrificação não ocorre de maneira acentuada em lagoas de estabilização e para remoção da amônia são necessários fatores importantes como: alto $\mathrm{pH}$ combinado com altas temperaturas e efeito da radiação solar. 
As figuras 7.46 e 7.47 apresentam as eficiências de remoção de NKT e nitrogênio amoniacal do sistema, com valores médios de $36,2 \%$ e $28,6 \%$, respectivamente, próximos ao observados na $1^{\text {a }}$ fase e que se enquadram aos valores adotados na fase de projeto (30 a 50\%). A lagoa anaeróbia apresentou remoções de NKT e nitrogênio amoniacal na ordem de $28,6 \%$ e $30,8 \%$, respectivamente.

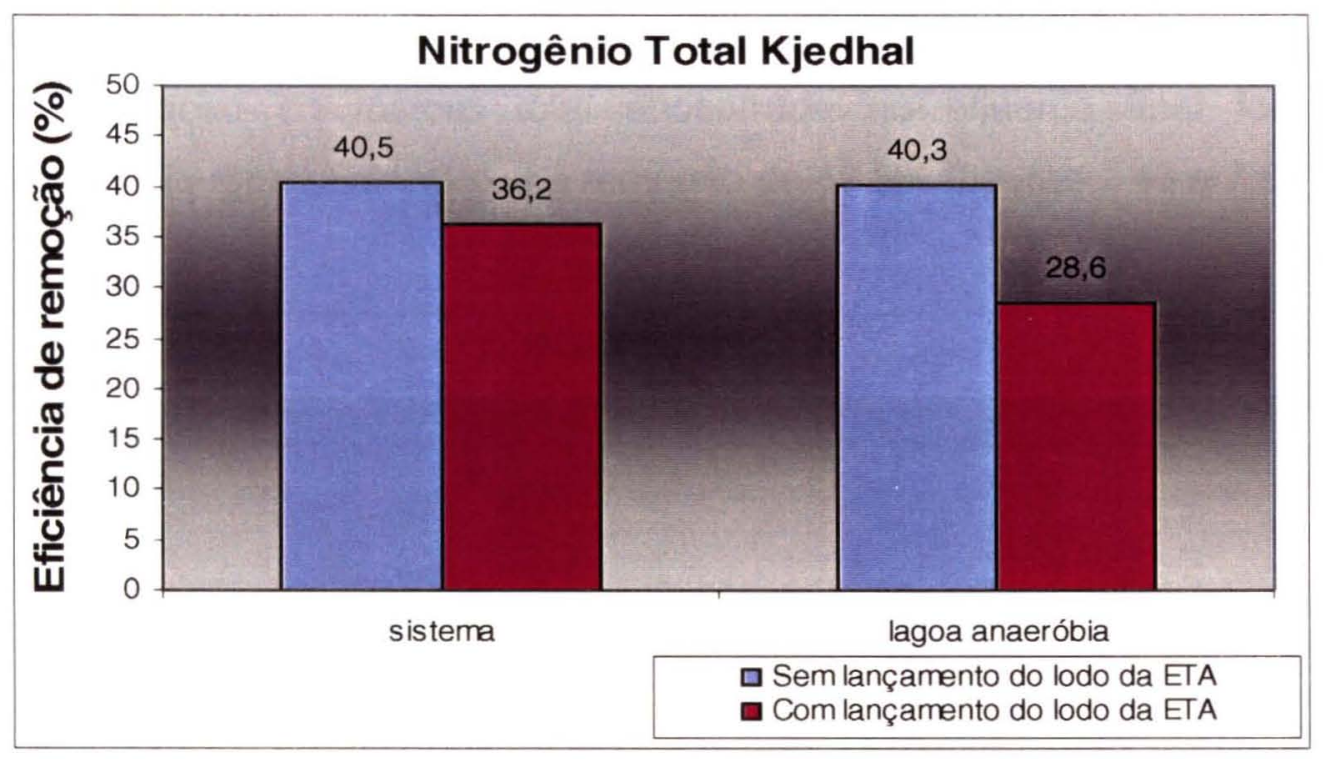

Figura 7.46 Eficiência de remoção de NKT do sistema e da lagoa anaeróbia.

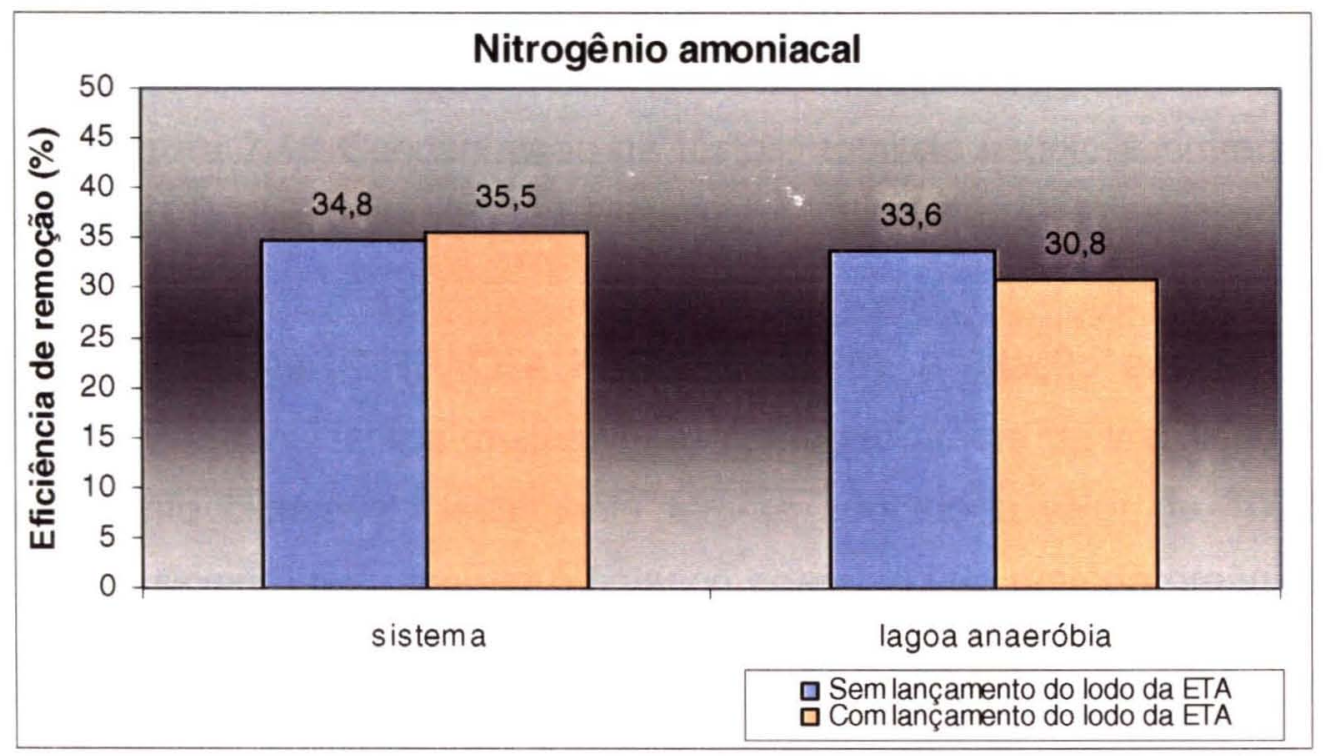

Figura 7.47 Eficiência de remoção nitrogênio amoniacal do sistema e da lagoa anaeróbia. 


\subsubsection{Fósforo Total}

SILVA et al (1991), atribuem a maior parte de remoção de fósforo total em lagoas primárias ao efeito da sedimentação. A concentração média de fósforo total do esgoto bruto foi de $6,4 \mathrm{mgP} / \mathrm{L}$, valor próximo ao encontrado na $1^{\text {a }}$ fase que foi de $5,8 \mathrm{mgP} / \mathrm{L}$. No efluente da lagoa anaeróbia foi encontrado valor de concentração de fósforo total em média de $3,7 \mathrm{mgP} / \mathrm{L}$, representando uma redução $42,4 \%$ e, a concentração do fósforo total encontrada no efluente final foi de $3,3 \mathrm{mgP} / \mathrm{L}$, representando uma remoção de $47,6 \%$ (figuras 7.48 a 7.51 ).

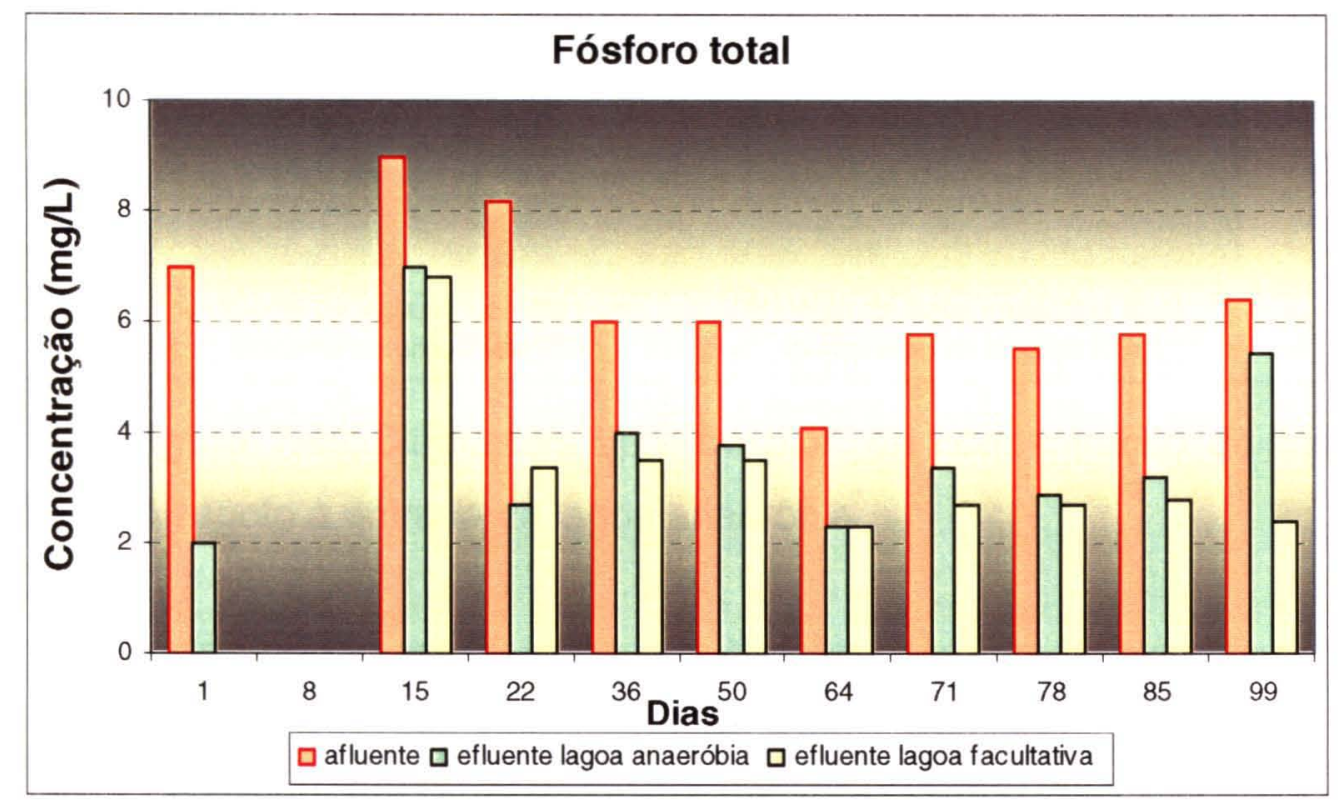

Figura 7.48 Concentração de fósforo total do esgoto à entrada e à saída das lagoas anaeróbia e facultativa.

Conforme JORDÃO e PESSOA (1995), a relação em peso de $\mathrm{DBO} / \mathrm{N} / \mathrm{P}$ é considerada muitas vezes como indicadora da viabilidade do tratamento biológico. Usualmente tem-se adotado o valor de 100:5:1 como suficiente para manter o balanço adequado de matéria orgânica e nutrientes para o tratamento biológico.

$\mathrm{Na} 1^{\text {a }}$ fase do projeto chegou-se a relação de $50: 8: 1$, nesta $2^{\mathrm{a}}$ fase foi observada relação de 48: 8:1. As relações DBO/N/P encontradas nas 
$1^{\text {a }}$ e $2^{\text {a }}$ fases não apresentaram variação significativa, porém, em estudos realizados pela CETESB (1981) em lagoas primárias, os afluentes apresentaram relação de $\mathrm{N}: \mathrm{P}$ de $7: 1$, valor próximo ao encontrado neste trabalho. De acordo com CETESB (1981), essa variação poderia estar relacionada à quantidade de detergentes presentes nos afluentes.

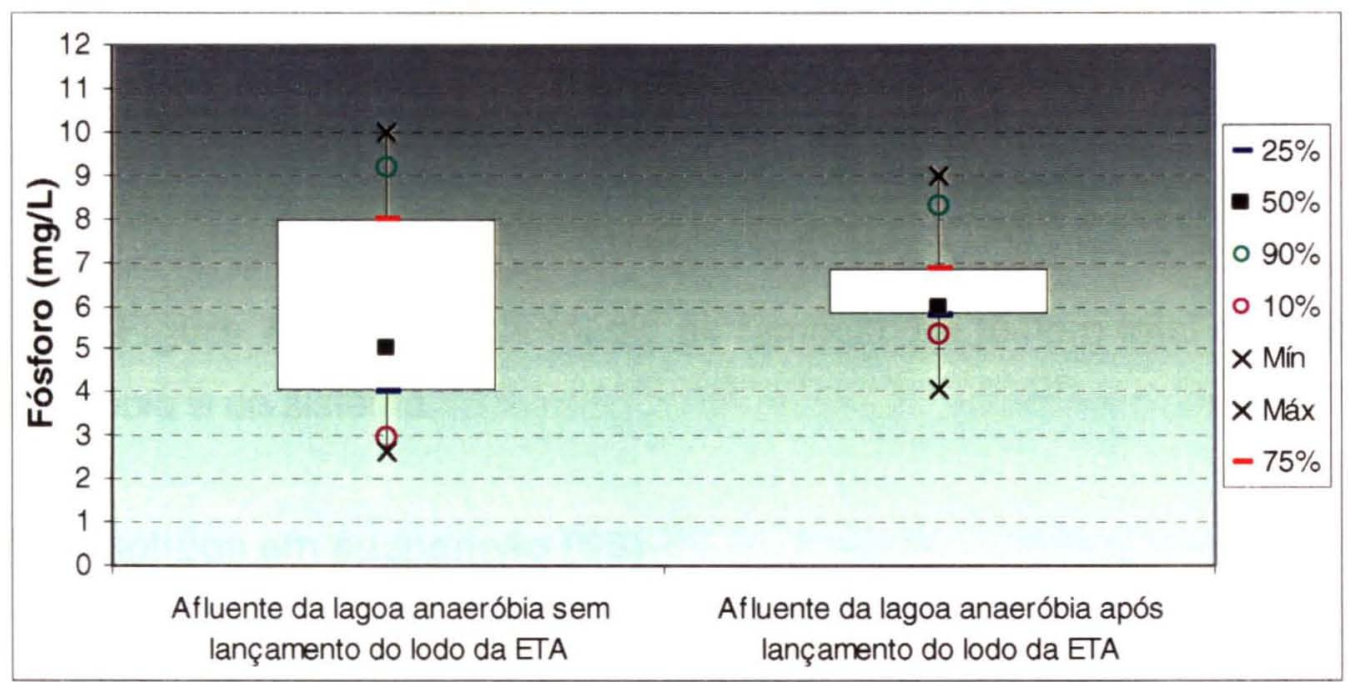

Figura 7.49 Diagramas tipo "boxplot" da concentração de fósforo total do esgoto à entrada da lagoa anaeróbia.

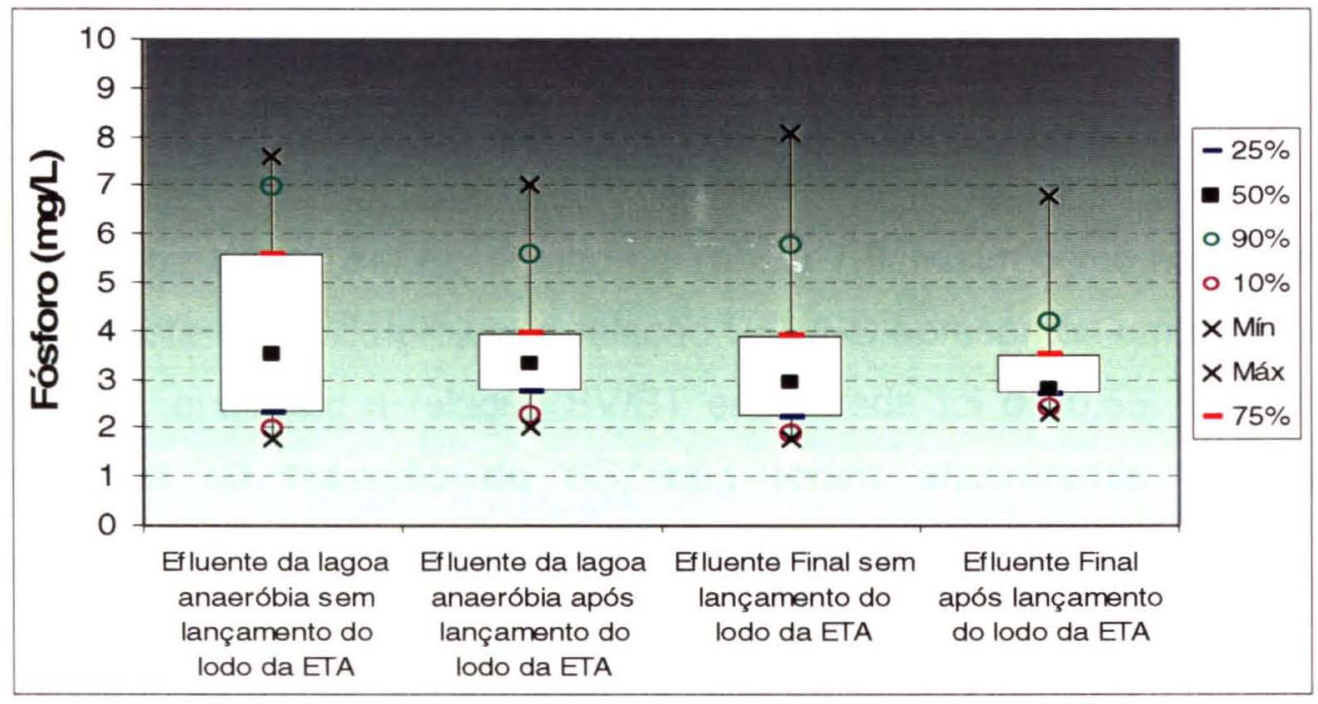

Figura 7.50 Diagramas tipo "boxplot" da concentração de fósforo total à saída das lagoas anaeróbia e facultativa. 


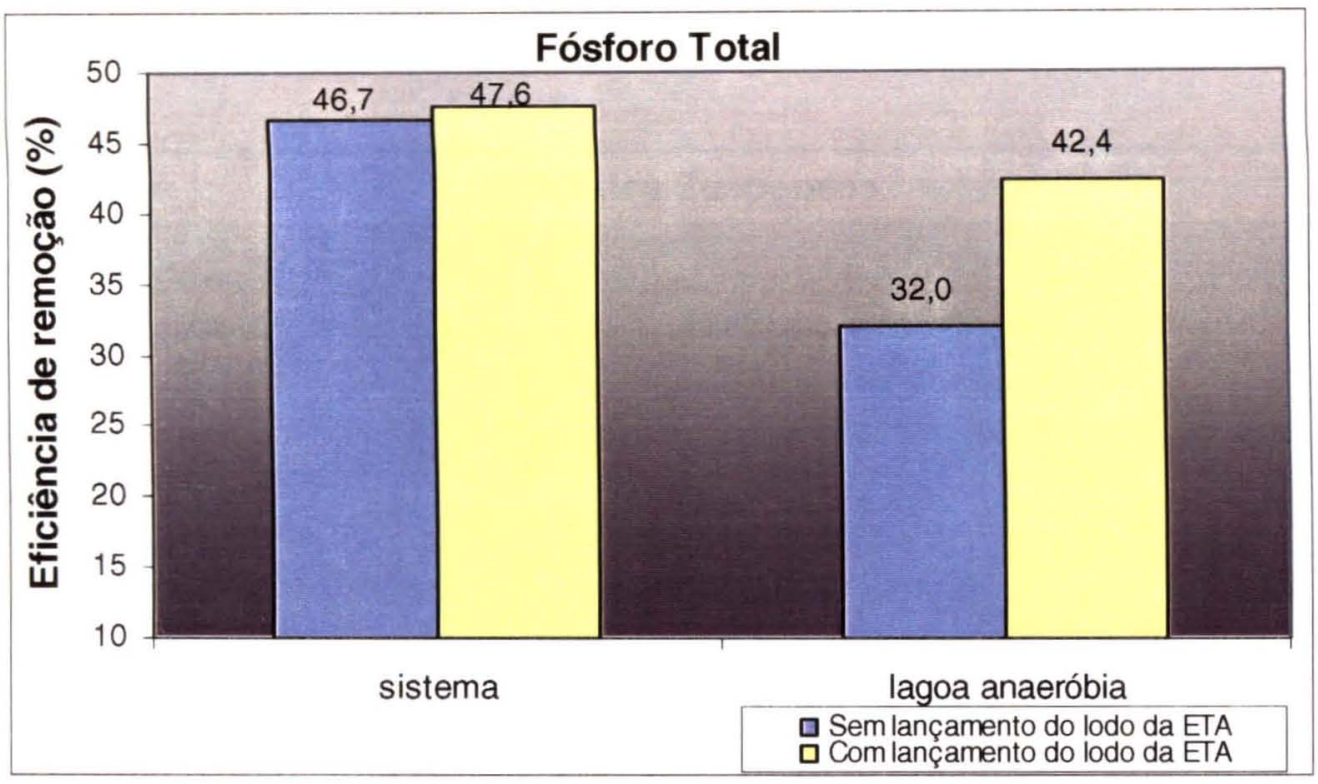

Figura 7.51 Eficiência média de remoção de fósforo total da lagoa anaeróbia e do sistema.

\subsubsection{Sólidos em suspensão (SS)}

Nas figuras 7.52 a 7.54 podem ser verificadas as variações de concentração de SS no esgoto bruto com valor médio de $243 \mathrm{mg} / \mathrm{L}$ e SSV de $163 \mathrm{mg} / \mathrm{L}$, o efluente da lagoa anaeróbia apresentou variações de concentração de SS na faixa de 56 a $253 \mathrm{mg} / \mathrm{L}$ com valor médio de $102 \mathrm{mg} / \mathrm{L}$ e o efluente final apresentou concentração média de $88 \mathrm{mg} / \mathrm{L}$ de SS e $73 \mathrm{mg} / \mathrm{L}$ de SSV.

Como pode ser observado na Tabela 7.6, assim como na primeira fase, nesta etapa do projeto a relação SSV/SS apresentou um resultado de 0,66, enquanto a relação SV/ST encontrada foi de 0,55. Quanto a eficiência de remoção de SS, não foram encontradas variações significativas entre as duas fases do projeto, conforme figura 7.55.

Durante o monitoramento, os resultados de sólidos sedimentáveis se mantiveram dentro dos padrões exigidos pelo CONAMA 357 e Decreto 8468/76. 


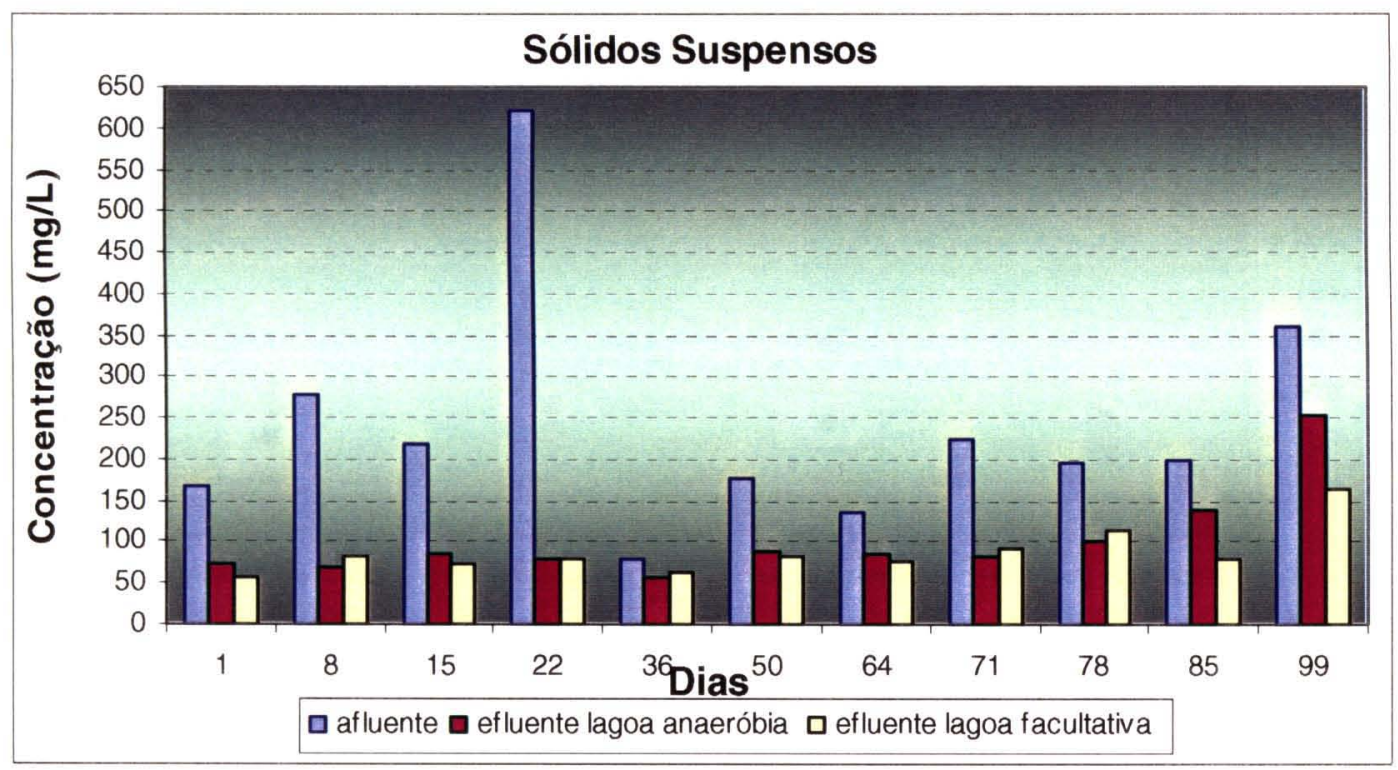

Figura 7.52 Concentração de sólidos suspensos do esgoto à entrada e à saída das lagoas anaeróbia e facultativa.

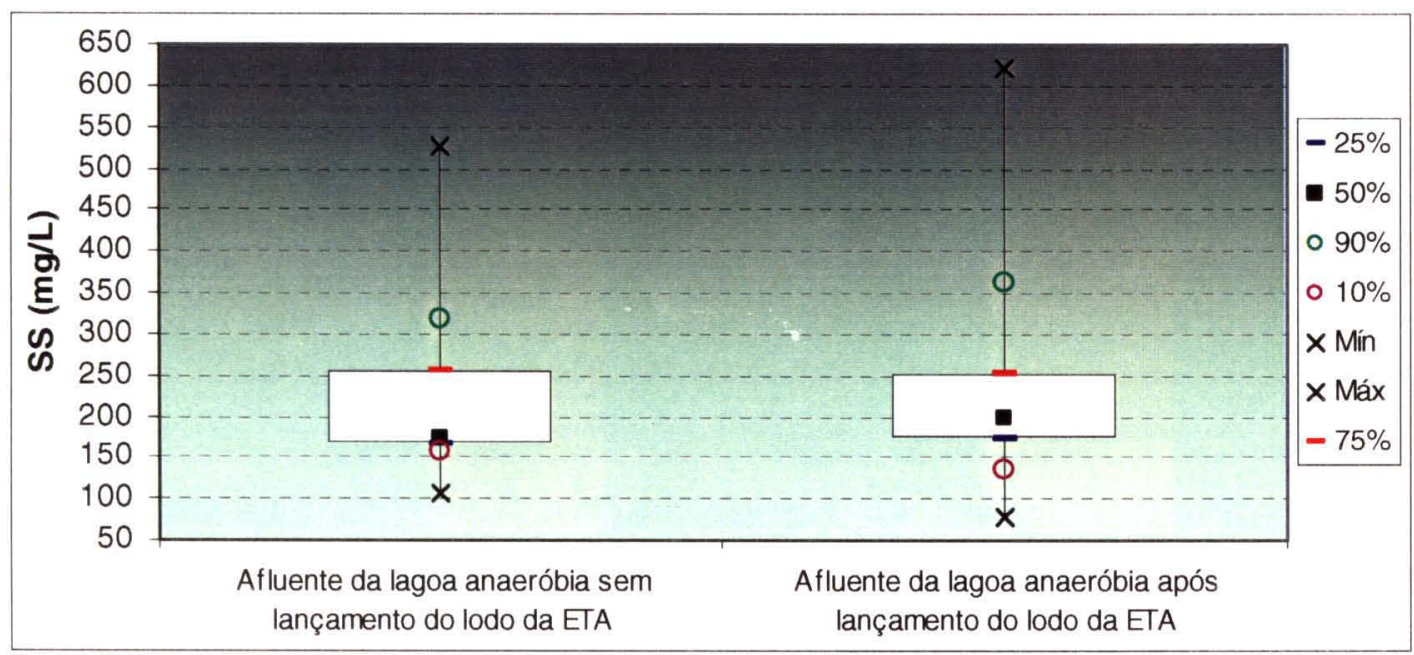

Figura 7.53 Diagramas tipo "boxplot" da concentração de sólidos suspensos do esgoto à entrada da lagoa anaeróbia. 


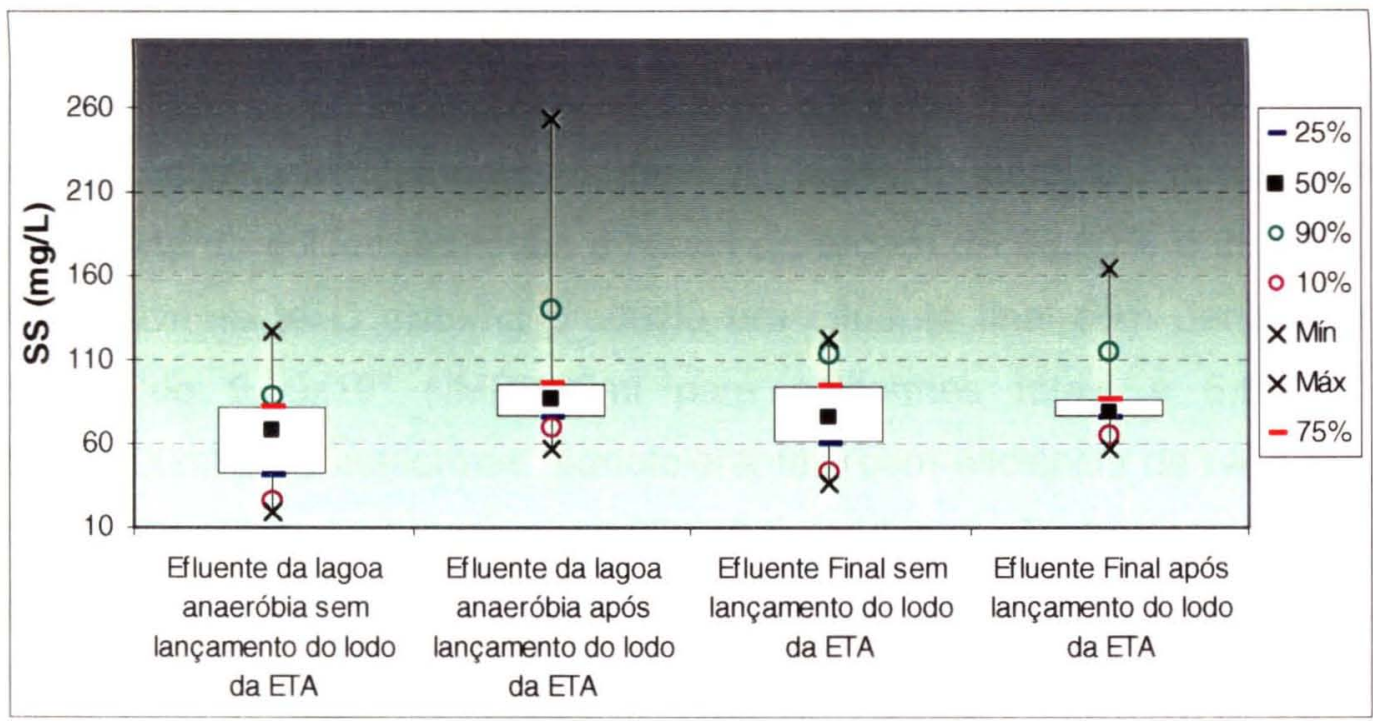

Figura 7.54 Diagramas tipo "boxplot" da concentração de sólidos suspensos do esgoto à saída das lagoas anaeróbia e facultativa.

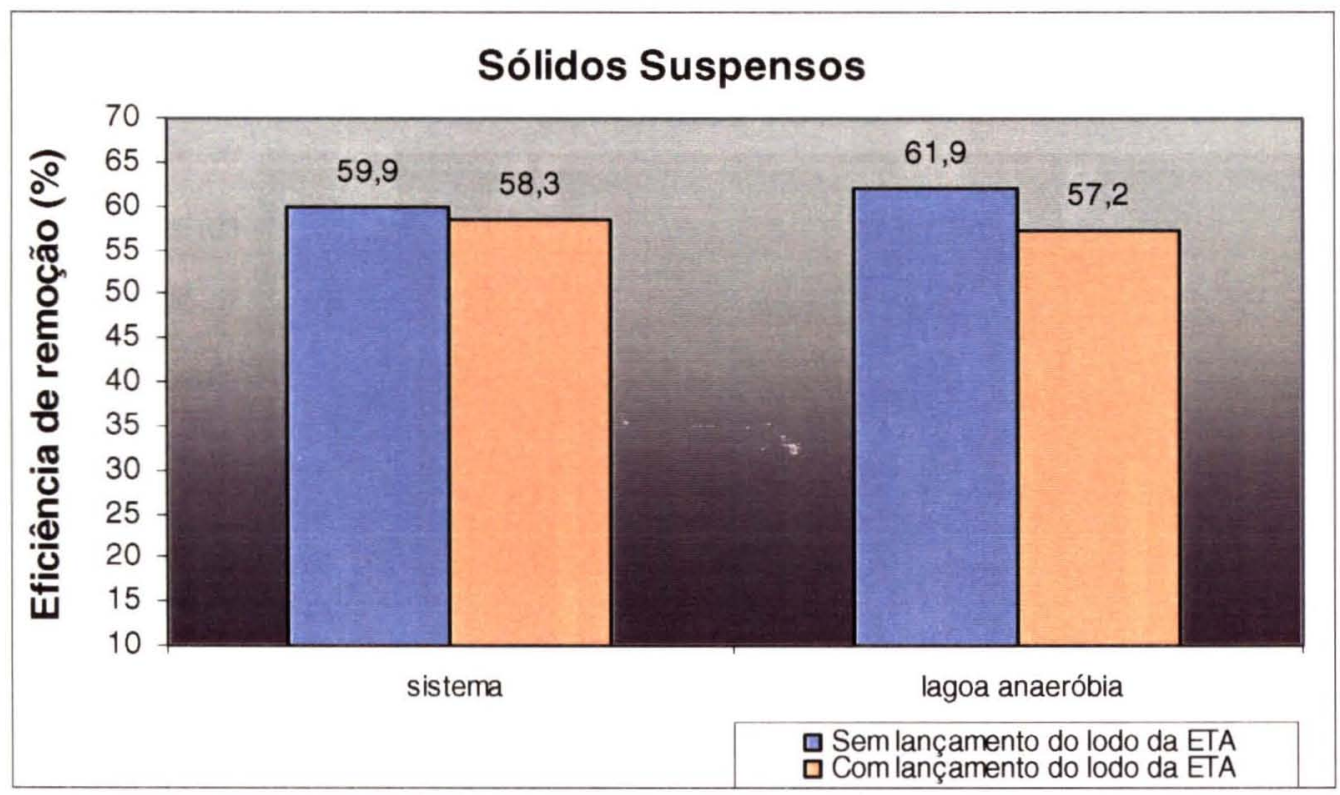

Figura 7.55 Eficiência média de remoção de sólidos suspensos da lagoa anaeróbia e do sistema. 


\subsubsection{Coliformes totais e coliformes termotolerantes}

Nesta fase do projeto, o esgoto bruto apresentou uma densidade média de $5,29 \times 10^{7} \mathrm{NMP} / 100 \mathrm{ml}$ de coliformes totais e $1,29 \times 10^{7} \mathrm{NMP} / 100$ $\mathrm{ml}$ de coliformes termotolerantes. A lagoa anaeróbia apresentou remoções de coliformes totais e fecais da ordem de $98,80 \%$ e $98,82 \%$, respectivamente $\mathrm{O}$ sistema produziu um efluente final com densidade média de $2,09 \times 10^{5} \mathrm{NMP} / 100 \mathrm{ml}$ para coliformes totais e $5,80 \times 10^{4}$ $\mathrm{NMP} / 100 \mathrm{ml}$ para coliformes termotolerantes, com eficiência de remoção de $99,6 \%$ (2,5 unid. log) e 99,6\% (2,5 unid log). Embora o projeto considerasse remoção da ordem de 60-99,9\%, o sistema apresentou baixa remoção de coliformes totais e termotolerantes ao se comparar com a primeira fase (figuras 7.56 a 7.63 ).

Tanto na primeira quanto na segunda fase do projeto, o sistema não atendeu os valores exigidos pelos órgãos ambientais, sendo necessária à aplicação de processos de desinfecção do efluente final.

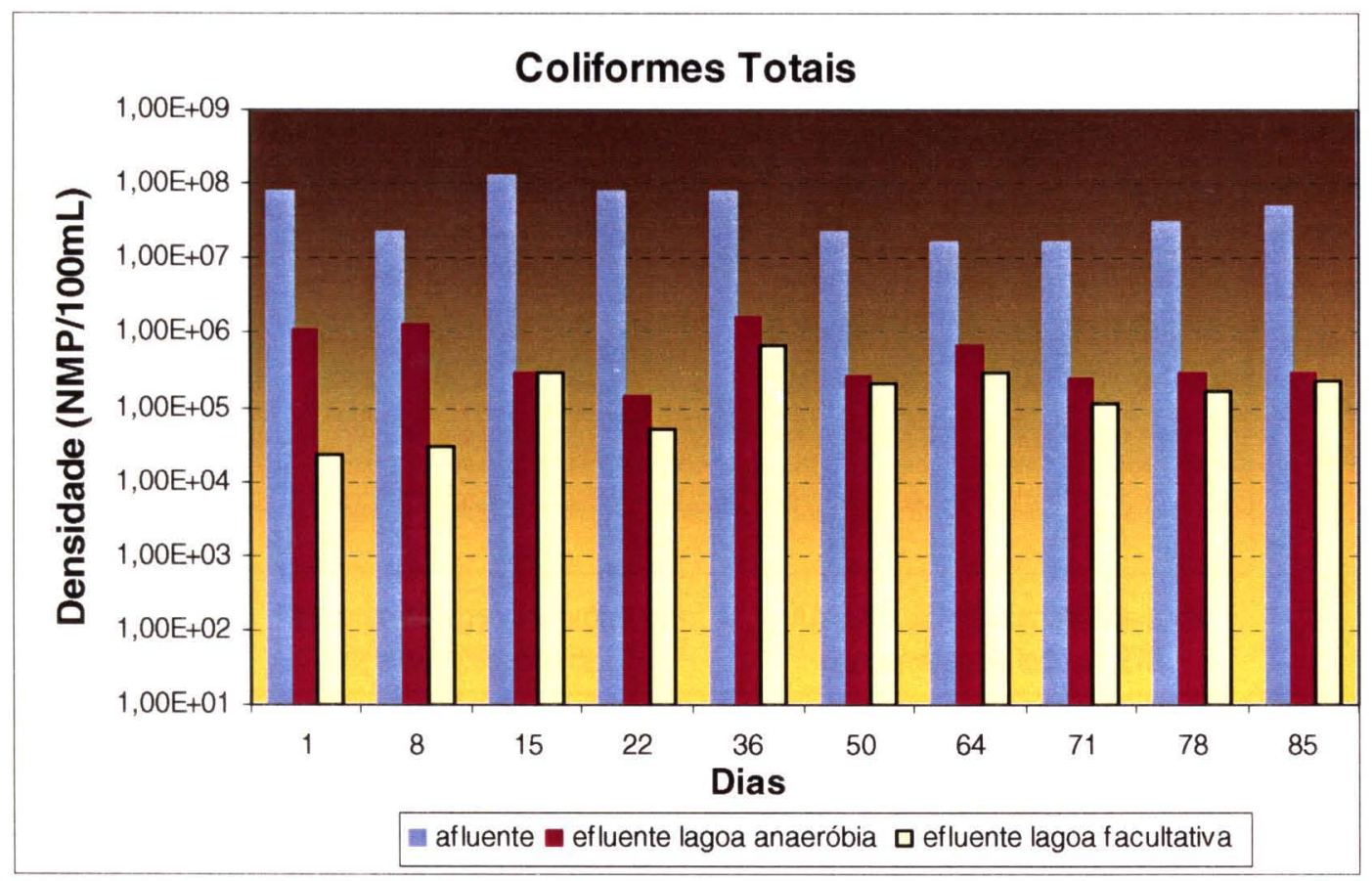

Figura 7.56 Densidade de coliformes totais do esgoto à entrada e à saída das lagoas anaeróbia e facultativa. 


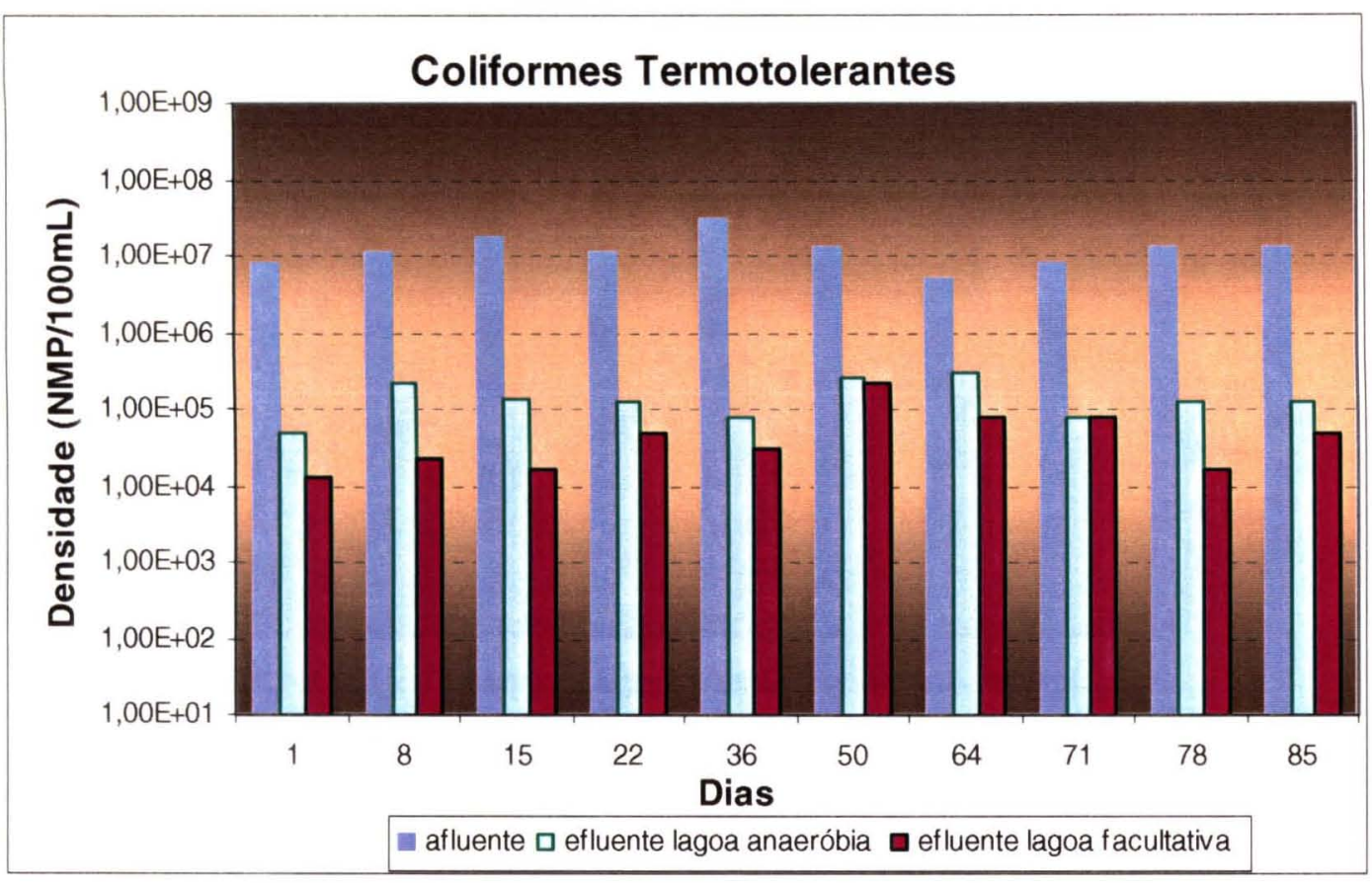

Figura 7.57 Densidade de coliformes termotolerantes (NMP/100ml) do esgoto à entrada e à saída das lagoas anaeróbia e facultativa.

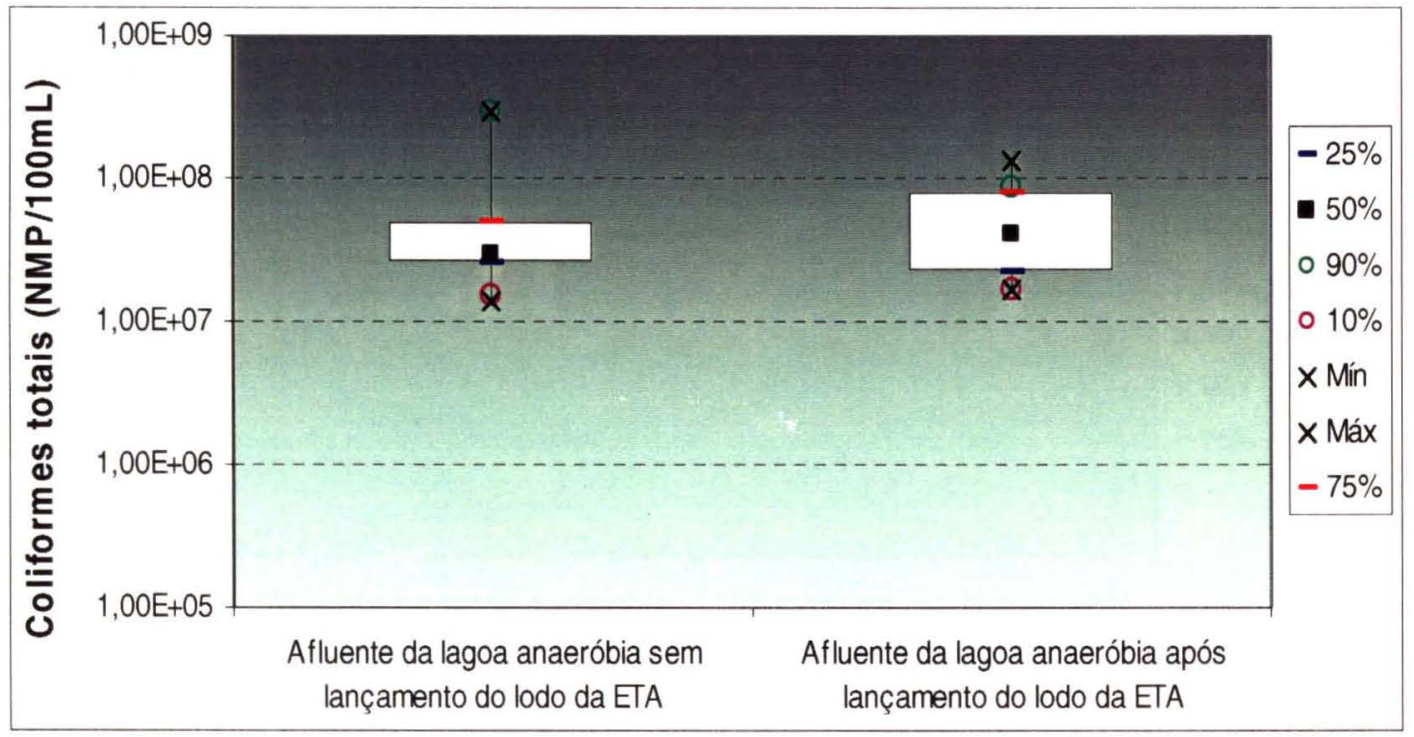

Figura 7.58 Diagramas tipo "boxplot" da densidade de coliformes totais do esgoto à entrada da lagoa anaeróbia. 


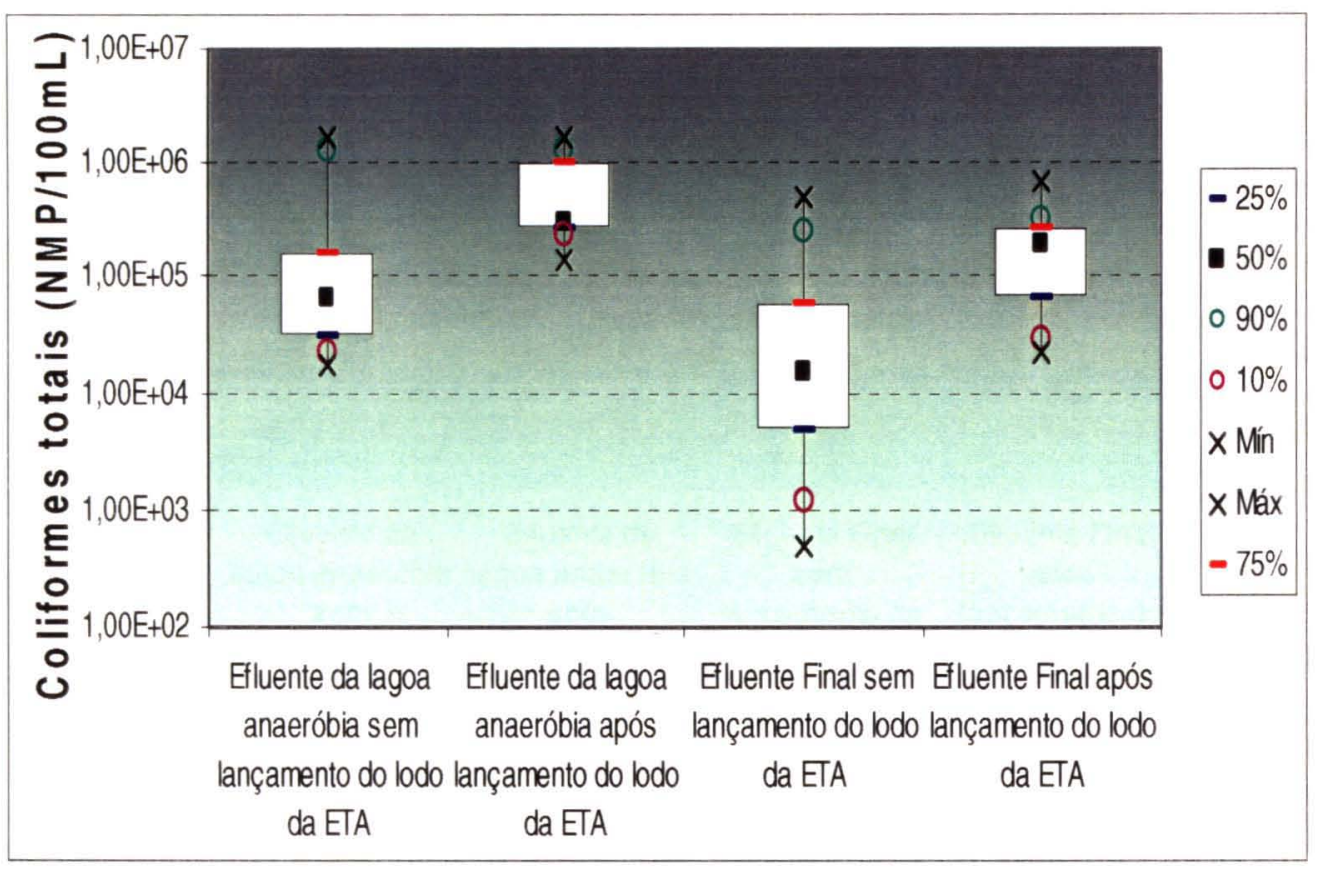

Figura 7.59 Diagramas tipo "boxplot" da densidade de coliformes totais do esgoto à saída das lagoas anaeróbia e facultativa.

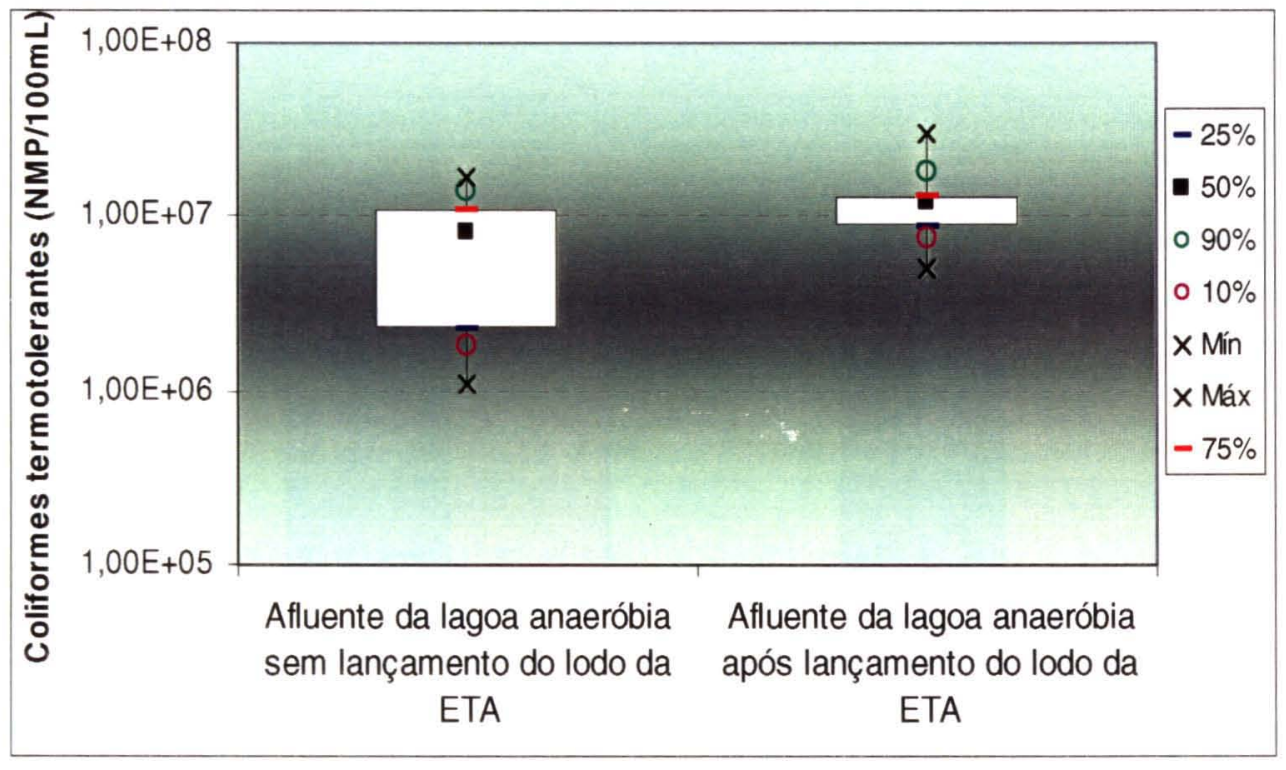

Figura 7.60 Diagramas tipo "boxplot" da densidade de coliformes termotolerantes do esgoto à entrada da lagoa anaeróbia. 


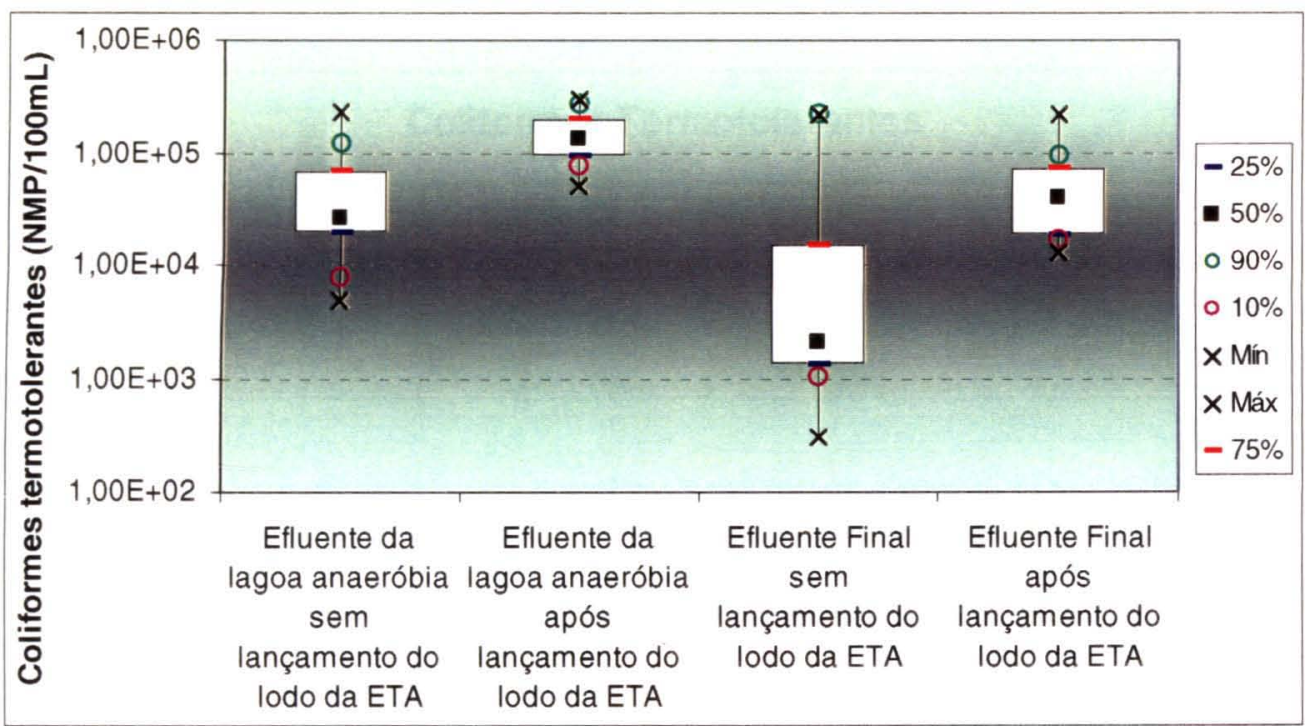

Figura 7.61 Diagramas tipo "boxplot" da densidade de coliformes termotolerantes do esgoto à saída das lagoas anaeróbia e facultativa.

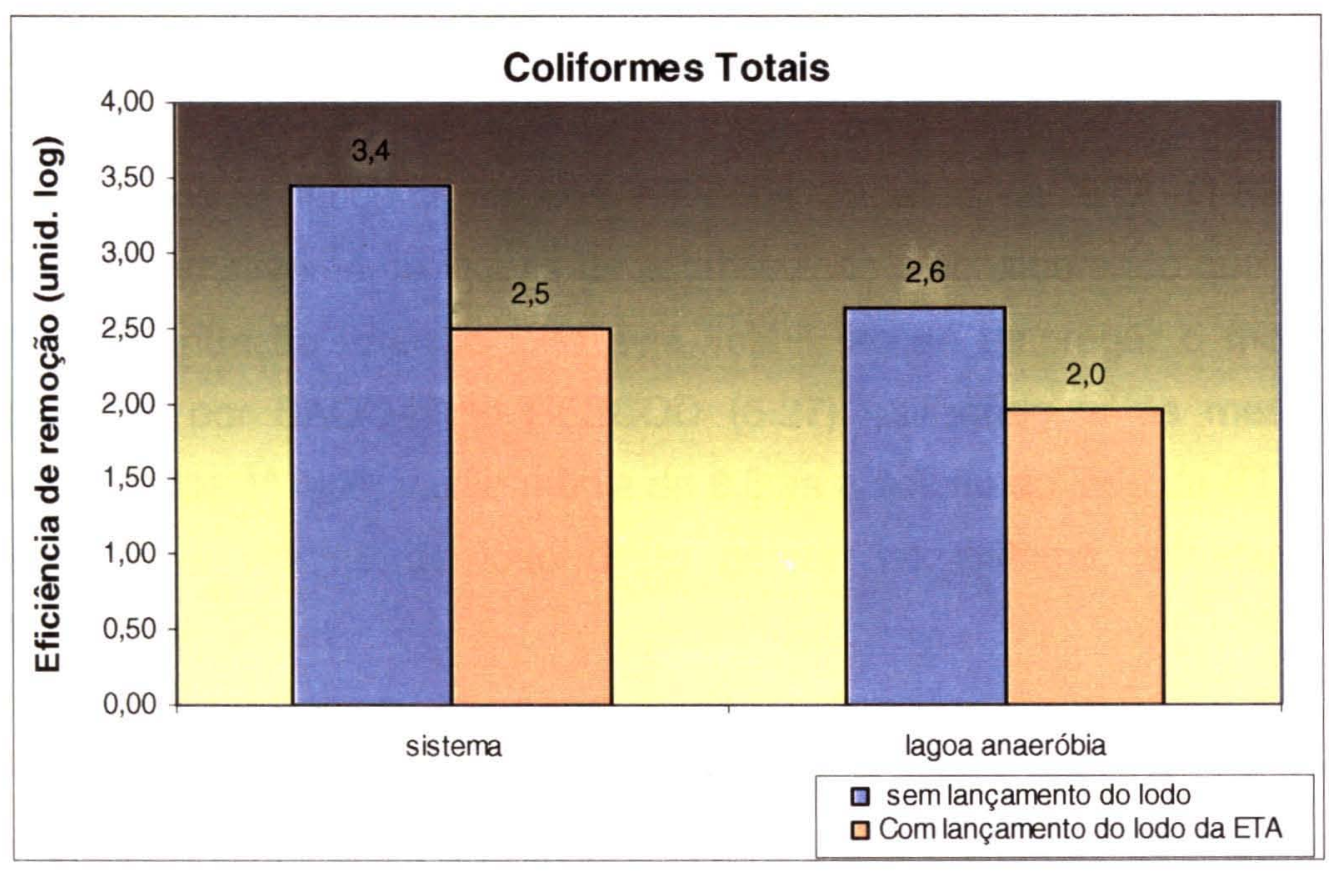

Figura 7.62 Eficiência de remoção de coliformes totais do sistema e da lagoa anaeróbia. 


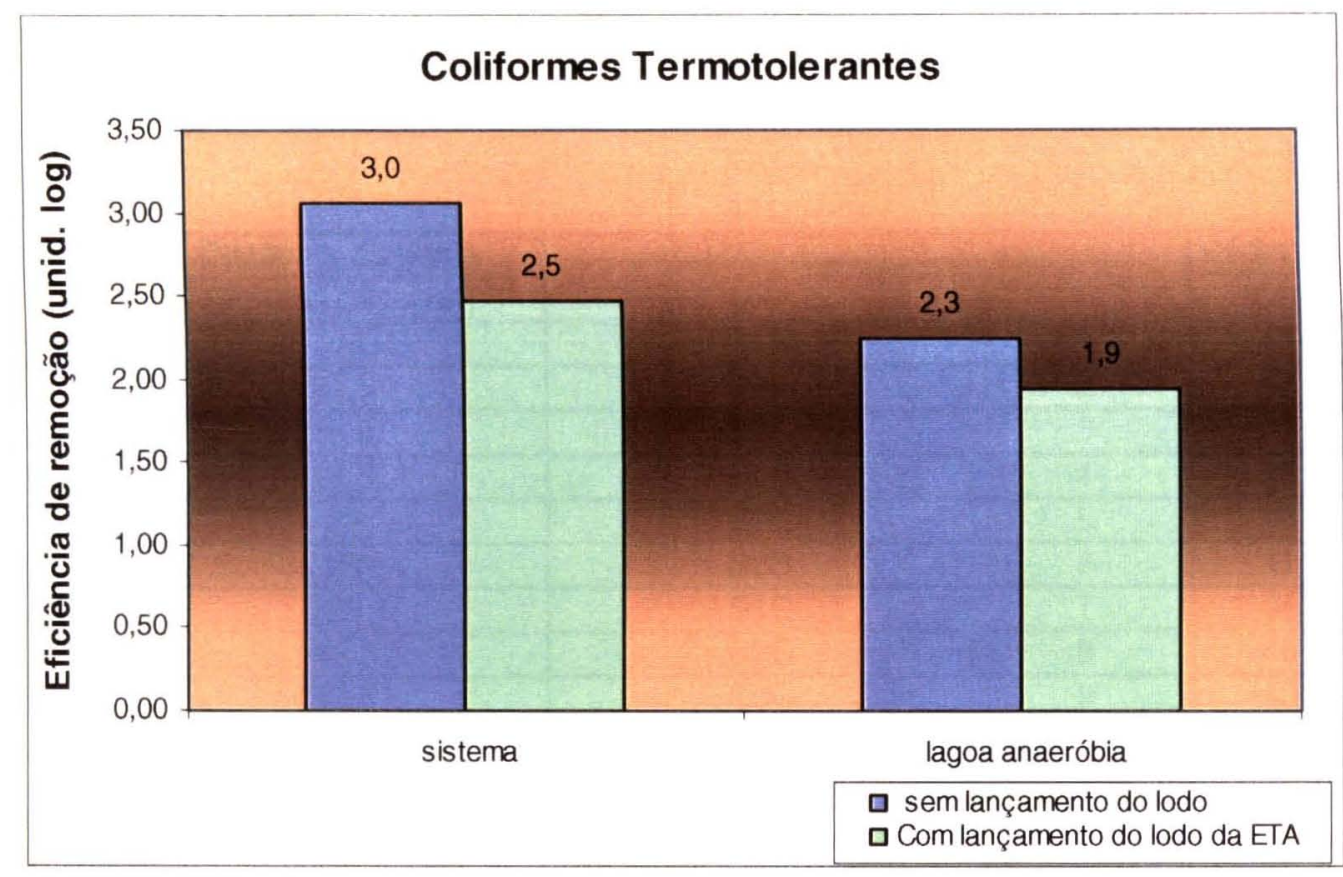

Figura 7.63 Eficiência de remoção de coliformes termotolerantes do sistema e da lagoa anaeróbia.

\subsubsection{Estimativa da Produção de Lodo em Lagoas Anaeróbias}

Após o lançamento dos resíduos gerados na ETA $(1.682,29$ $\mathrm{kg} / \mathrm{mês}$ ) no sistema de lagoas de estabilização e considerando que $10 \%$ da concentração total do lodo seja volátil, ao se empregar o modelo proposto por SAQQAR e PESCOD (5.27), utilizando-se as mesmas variáveis da $1^{\text {a }}$ fase, vazão média de $8,5 \mathrm{l} / \mathrm{s}$ e adição do lodo da ETA na estação, o volume de lodo diário gerado no sistema resultou em $0,39 \mathrm{~m}^{3} / \mathrm{d}$.

A taxa média anual de lodo calculada nesta fase da pesquisa resultou em $15 \mathrm{~cm} /$ ano. Após a realização de ensaios batimétricos, conforme tabela 7.7 e figura 7.64 , foram encontrados os seguintes valores de espessura da camada de lodo nos 9 pontos da lagoa anaeróbia: 
Tabela 7.64 Resultado de ensaio batimétrico na lagoa anaeróbia.

\begin{tabular}{|c|c|c|c|}
\hline Distância da borda & \multicolumn{2}{|c|}{ Ponto } & Média \\
\cline { 3 - 4 } (entrada da lagoa) & \multicolumn{2}{|c|}{$(\mathrm{cm})$} \\
\hline$(\mathrm{m})$ & S1A & 1 & 53 \\
\hline 14,5 & S2A & 2 & 57 \\
\hline 14,5 & S3A & 3 & 51 \\
\hline 14,5 & S1B & 4 & 45 \\
\hline 29 & S2B & 5 & 48 \\
\hline 29 & S3B & 6 & 41 \\
\hline 29 & S1C & 7 & 34 \\
\hline 43,5 & S2C & 8 & 43 \\
\hline 43,5 & S3C & 9 & 40 \\
\hline 43,5 & & Média total & 46 \\
\hline
\end{tabular}

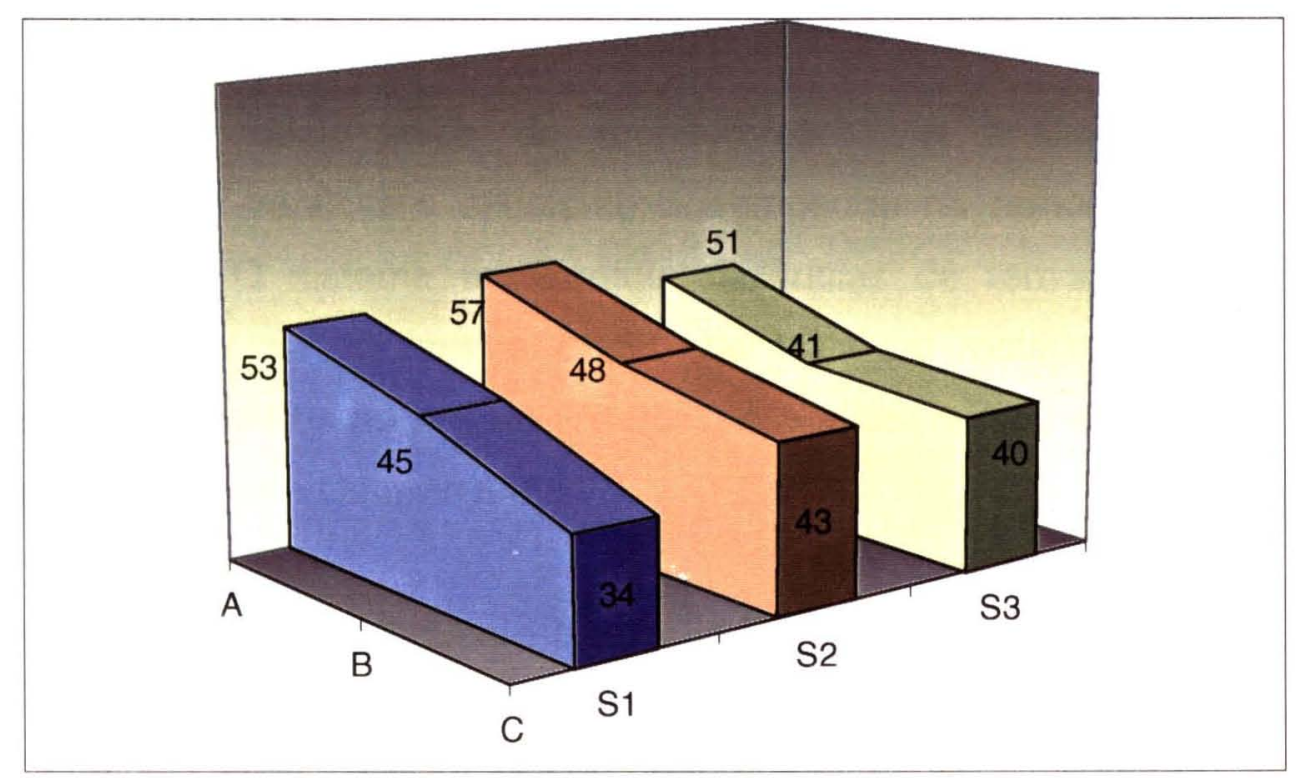

Figura 7.64 Espessura da camada de lodo na lagoa anaeróbia. 


\section{CONCLUSÃo}

Foi verificado que a lagoa anaeróbia em diversos momentos do monitoramento apresentou características semelhantes à lagoa facultativa, principalmente na saída, com florações de algas e efluente com cor esverdeada. KAWAI (1981) chegou à conclusão que lagoas anaeróbias tendem a funcionar como facultativa com TDH superior a 6,0dias. $\mathrm{Na} 1^{\text {a }}$ fase e $2^{\mathrm{a}}$ fase do projeto, foram observados TDH de 7,5 e 7,0 dias respectivamente.

MARA (1976) também ressalta que para manter a anaerobiose da lagoa, a taxa de aplicação volumétrica $\left(\lambda_{v}\right)$ deve ser superior a $100 \mathrm{~g} \mathrm{DBO} / \mathrm{m}^{3 *} \mathrm{~d}$. No presente trabalho as duas fases apresentaram em média taxas de aplicação volumétrica de 38 e $60 \mathrm{~g} \mathrm{DBO} / \mathrm{m}^{3 *} \mathrm{~d}$, respectivamente.

Durante as duas fases do monitoramento, a análise dos resultados permitiu verificar o excelente desempenho na remoção de material orgânico. O sistema apresentou eficiências de remoção de $\mathrm{DBO}_{5,20}$, de $90,5 \%$ na $1^{\mathrm{a}}$ fase e $88,8 \%$ na $2^{\mathrm{a}}$. Tais resultados se enquadram aos previstos no projeto (70-90\%) e o efluente final atendeu os valores exigidos pelo Decreto $8468 / 76$.

Os resultados obtidos quanto à relação $\mathrm{DQO} / \mathrm{DBO}$ demonstraram também a ótima eficiência do sistema na remoção da matéria orgânica, uma vez que, nas duas fases, a relação encontrada no esgoto bruto foi de $2 / 1$ e no efluente final foi observada relação de $5 / 1$ ( $1^{a}$ fase $)$ e $6 / 1\left(2^{a}\right.$ fase).

A eficiência de remoção de nutrientes apresentou-se dentro dos parâmetros de projeto, tanto para os compostos nitrogenados (30 a $50 \%$ ), quanto para o fósforo (20 a $60 \%$ ). Durante a $1^{a}$ fase do projeto foi 
constatada uma eficiência média de remoção de fósforo de $46,7 \%$, ou seja, a concentração de fósforo do esgoto bruto passou de $5,8 \mathrm{mgP} / \mathrm{L}$ para $3,5 \mathrm{mgP} / \mathrm{L}$ no efluente final. $A 2^{\mathrm{a}}$ fase não apresentou grandes variações nas concentraçōes do esgoto bruto, do efluente da lagoa anaeróbia e do efluente final. A concentração média de fósforo no esgoto bruto observada foi de $6,4 \mathrm{mg} / \mathrm{L}$ e no efluente final foi $3,7 \mathrm{mgP} / \mathrm{L}$, representando uma eficiência média de remoção de $47,6 \%$. Foi verificada uma remoção significativa de fósforo apenas em algumas coletas devido a elevação do $\mathrm{pH}$ do sistema. No efluente da lagoa anaeróbia as concentrações médias encontradas na $1^{\mathrm{a}}$ fase e na $2^{\mathrm{a}}$ fase foram 4,1 mgP/L e 3,7 mgP/L, respectivamente.

Quanto ao nitrogênio, foram observadas eficiências de remoção de $40,5 \%$ para NKT e $34,8 \%$ para nitrogênio amoniacal na $1^{a}$ fase $e$, $36,2 \%$ para NKT e $35,5 \%$ para nitrogênio amoniacal na $2^{\mathrm{a}}$ fase. As concentrações médias de NKT e nitrogênio amoniacal, respectivamente, do esgoto bruto $(48,5 \mathrm{mg} / \mathrm{L} ; 26,9 \mathrm{mg} / \mathrm{L})$, do efluente da lagoa anaeróbia $(28,0 \mathrm{mg} / \mathrm{L} ; 17,8 \mathrm{mg} / \mathrm{L})$ e do efluente final $(28,2 \mathrm{mg} / \mathrm{L} ; 17,5 \mathrm{mg} / \mathrm{L})$ da $1^{\mathrm{a}}$ fase se mantiveram próximas às verificadas na $2^{a}$ fase, com os seguintes resultados: no esgoto bruto $(55,2 \mathrm{mg} / \mathrm{L} ; 35,1 \mathrm{mg} / \mathrm{L})$, no efluente da lagoa anaeróbia (39,4mg/L; 24,3mg/L) e no efluente final (36,5mg/L; 22,6mg/L). Quanto à concentração de nitrogênio amoniacal, em algumas fases do monitoramento, o efluente final das duas fases atendeu os valores exigidos pelo CONAMA 357/05.

Apesar dos altos resultados de remoção de patógenos encontrados para coliformes totais e fecais na $1^{\text {a }}$ fase $(99,9 \%$ e $99,9 \%)$ respectivamente, na $2^{\mathrm{a}}$ fase $(99,60 \%$ e $99,5 \%)$, o efluente final não atendeu os valores exigidos pelo decreto 8468/76 e CONAMA 357/05. Para o perfeito enquadramento da legislação o efluente final precisa passar por um processo de desinfecção antes do lançamento no corpo receptor. 
Ao se comparar os resultados obtidos nas duas fases do projeto, utilizando o modelo proposto por SAQQAR e PESCOD na determinação do volume de lodo gerado em lagoas de estabilização $\left(14 \mathrm{~cm} / \mathrm{ano}\right.$ na $1^{\mathrm{a}}$ fase e $15 \mathrm{~cm} /$ ano na $2^{\mathrm{a}}$ fase), pode-se verificar que a quantidade de resíduo gerado na ETA e lançado na lagoa anaeróbia não alterou consideravelmente o volume do material sólido resultante das atividades biológicas dos microrganismos (diferença entre as duas fases de $1 \mathrm{~cm} / \mathrm{ano}$ ). Após ensaios batimétricos observou-se que tanto na $1^{\mathrm{a}}$ quanto na $2^{\mathrm{a}}$ fase do projeto, a média da taxa de acumulação anual de lodo se manteve próxima a 10,0 e $11,4 \mathrm{~cm} / \mathrm{ano}$, respectivamente.

Como visto anteriomente, até o presente momento do monitoramento, o lançamento dos resíduos gerados na ETA no sistema de lagoas de estabilização do município de São Lourenço, que utiliza sulfato de alumínio como coagulante, não alterou de maneira significativa as características físico-químicas e biológicas do esgoto bruto e não interferiu nos processos biológicos verificados neste tipo de tratamento, mantendo o desempenho da estação dentro dos valores estimados na fase de dimensionamento.

\section{CONSIDERAÇÕES FINAIS}

Se houver interesse em dispor resíduos gerados na ETA em ETE's, independente do tipo de coagulante ou tecnologia empregada na $E T E$, que sejam realizados estudos das características físico-químicas e bacteriológicas (turbidez, Sólidos em suspensão, coliformes totais e termotolerantes, $\mathrm{pH}$, temperatura, etc.) desse material.

Antes de se lançar resíduos de ETA em estações de tratamento de esgoto, é preciso que sejam verificadas as condições de operação da ETE com possiveis intervenções, para que após o lançamento, os resíduos da ETA não interfiram nos processos de tratamento de esgoto, alterando a qualidade do efluente final. 
É importante ressaltar que os sistemas de lagoas de estabilização apesar de não exigirem mecanismos sofisticados e dispendiosos para sua manutenção, necessitam atenção especial quanto à remoção de material grosseiro no gradeamento e limpeza dos resíduos nas caixas de areia.

Sejam efetuados, após receber os resíduos da ETA, levantamentos de custos $\theta$ avaliações do lodo gerado na ETE, verificando as vantagens e desvantagens da disposição final desse material, com possibilidades de aplicação na agricultura. 


\section{REFERÊNCIAS BIBLIOGRÁFICAS}

Aisse MM, Van Haandel AC, Von Sperling M, Campos JR, Couracci Filho B, Além Sobrinho P. Tratamento e destino final do lodo gerado em reatores anaeróbios. In: Programa de Pesquisa em Saneamento Básico. Tratamento de esgotos sanitários por processos anaeróbios e disposição controlada no solo. Rio de Janeiro: ABES; 1999. p. 271299

Arceivala SJ. Wastewater tratment and disposal: In:Engineering and Ecology in Pollution Control. New York: Marcel Dekker; 1981

AWWA - American Water Works Association. Standard methods for the examination of water and wastewater. $18^{\text {th }}$ ed. Wasington (DC); 1993.

Azevedo Netto JM. Técnica de abastecimento de água. São Paulo: $3^{a}$ ed. CETESB/ASCETESB; 1986. v. 2. Considerações gerais sobre projetos de tratamento de água.

Azevedo Netto JM. Lagoas de estabilização, generalidades desenvolvimento - histórico - bibliografia. In: Universidade de São Paulo: Faculdade de Higiene e Saúde Pública; Lagoas de Estabilização. São Paulo: 1967. p. 1-6.

Babbitt HE, Dolland JJ, Cleasby JL. Abastecimento de água. São Paulo: Edgard Blucher; 1976.

Barnes D, Bliss PJ, Gould BW; Vallentine HR. Water treatment. In: Water and wasterwater engineering systems. Massachusetts: Pitman; 1981. p.296-367. 
Braga B, Hespanhol I, Spencer Milton, Porto M, Nucci N, Eiger S et al. O meio aquático. In: Universidade de São Paulo. Escola Politécnica. Departamento de Engenharia Hidráulica e Sanitária. Introdução à engenharia ambiental. $2^{\mathrm{a}}$ ed. São Paulo: Prentice Hall; 2003. p.72-122.

Branco SM. Hidrologia ambiental. São Paulo: Edusp; 1991. v. 3. A água e o homem. p-3-25.

Branco SM. Hidrobiologia aplicada à engenharia sanitária. $3^{\mathrm{a}}$ ed. São Paulo: CETESB/ASCETESB; 1986.

Branco SM. Conceito, definições, classificação. In: Universidade de São Paulo: Faculdade de Higiene e Saúde Pública; Lagoas de Estabilização. São Paulo: 1967. p. 9-13.

Bratby, JR; Ambrose, WA. Design and control of flotation thickeners. J Water Sci and Technol 1995; 31 (3-4): 247-261.

[CETESB] Companhia de Tecnologia de Saneamento Ambiental. Avaliação de desempenho de lagoas de estabilização. São Paulo: 1990.

[CETESB] Companhia de Tecnologia de Saneamento Ambiental. Operação e manutenção de lagoas anaeróbias e facultativas. São Paulo: 1989.

[CETESB] Companhia de Tecnologia de Saneamento Ambiental. Relatório de qualidade das águas interiores do estado de São Paulo 2003. São Paulo: 2004.

Cordeiro JS. Importância do tratamento e disposição adequada dos lodos de ETA's. In: Programa de Pesquisa em Saneamento Básico. Noções gerais de tratamento e disposição final de lodos de estaçōes de tratamento de água. Rio de Janeiro: ABES; 1999 p. 1-20. 
Cornwell DA, Koppers HMN. Slib, schlamm, sludge. Denver: AWWA Research Foundation; 1990.

Cornwell DA. Water treatment plant management. Denver: AWWA Research Foundation; 1987.

Di Bernardo L, Di Bernardo A, Centurione Filho PL. Ensaios de tratabilidade de água e dos resíduos gerados em estações de tratamento de água. São Carlos: RIMA; 2002.

Di Bernardo L. Métodos e técnicas de tratamento de água. Rio de Janeiro: ABES, 1993 v 1.

Ferreira Filho SS, Lage Filho. Comportamento químico do alumínio e do ferro em meio aquoso e implicações no tratamento de água. Rev Sanare 1996; 6:.50-58.

Ferreira Filho SS. Determinação dos mecanismos de coagulação para águas com baixa turbidez: estudo experimental. In: $17^{\circ}$ Congresso Brasileiro de Engenharia Sanitária e Ambiental; 1993 Set 19-23; Natal, Brasil. Rio de Janeiro: ABES; 1993. p.588-612.

Femandes NA. Balanço de massa e produção de lodo da estação de tratamento de água Alto da Boa Vista - SABESP. São Paulo; 2002. [Dissertação de mestrado - Escola Politécnica da Universidade de São Paulo]

Gloyna EF. Waste stabilization ponds. Genebre: World Health Organization, 1971.

Gonçalves RF. Introdução ao gerenciamento do lodo de lagoas de estabilização In: Programa de Pesquisa em Saneamento Básico. Gerenciamento do lodo de lagoas de estabilização não mecanizadas. Rio de Janeiro: ABES; 1999 p. 1-5. 
Grandin SR. Desidratação dos lodos produzidos nas estações de tratamento de água. São Paulo; 1992. [Dissertação de mestrado Escola Politécnica da Universidade de São Paulo]

Heller L, Libânio M. Projeto e operação de estações de tratamento de água - Módulo 1: fundamentos teóricos e operacionais. Belo Horizonte: Universidade Federal de Minas gerais, Convênio ASSEMAEFNS; 1996. p.100.

[IBGE] Instituto Brasileiro de Geografia e Estatística. Pesquisa nacional de saneamento básico 2000. Departamento de População e Indicadores Sociais. Rio de Janeiro: 2002. p.431

[ICMFS] International Comission on Microbiological Specification For Foods - Ecologia microbiana de los alimentos 1 - factores que afectan a la supervivencia de los microrganismos en los alimentos. Zaragoza (España): Editorial Acribia; 1980. p. 332.,

Ito LY, Tsutiya MT. Características de biossólidos gerados em estações de tratamento de esgoto. In Biossólidos na agricultura. $2^{a}$ ed. São Paulo: ABES; 2002. p.89-132.

Jordão EP, Pessôa CA. Tratamento de esgotos domésticos. $3^{\text {a }}$ ed. São Paulo: ABES; 1995.

Kawai H, Yano T, Rocha MJM, Scheneiderman B. Estabelecimentos de critérios para dimensionamento de lagoas de estabilização. Rev DAE 1981; (127): 37-45.

Kawamura S. Integrated and design of water treatment facilities. New York: John Wiley; 2000.

Kellner E, Pires EC. Lagoas de estabilização: projeto e operação Rio de Janeiro: ABES; 1998. 
König A. Biologia das lagoas: algas. In: Mendonça SR. Lagoas de estabilização e aeradas mecanicamente: novos conceitos. João Pessoa: 1990. p. 57-87.

Macedo JAB. Águas \& águas. $2^{\mathrm{a}}$ ed Belo Horizonte: Conselho Regional de Química, 2004.

Mancuso PCS, Santos HF. A escassez e o reuso de água em âmbito mundial. In: Reuso de Água. Barueri: Manole; 2003. p. 1-19.

Mendonça SR. Sistemas de lagunas de estabilización. Santa Fé de Bogotá: 2000.

Mendonça SR. : Lagoas de estabilização e aeradas mecanicamente: novos conceitos. João Pessoa: 1990. Lagoas de Estabilização; p. 235277.

Metcalf \& Eddy. Wastewater engineering: treatment and reuse. $4^{\text {th }} \mathrm{ed}$. New York: Mc Graww Hill; 2003.

Montgomery, JM. Water treatment principles and design. New York: Jonh Wiley; 1985.

Naval LP, André CMG, Souza LA. Aplicação de modelo probabilístico em um sistema de lagoas de estabilização de Palmas - TO. [CD Rom]. In: $21^{\circ}$ Congresso Brasileiro de Engenharia Sanitária e Ambiental; 2001 Set 16-21; João Pessoa, Brasil. Rio de Janeiro: ABES; 2001.

Nelson KL, Cisneros BJ, Tchobanoglous G, Darby JL. Sludge accumulation, characteristics and pathogen inactivation in four primary waste stabilization ponds in Central México. Water Res 2004; 38: 111127. 
O'Connor JT. Management of water treatment plant residues. In: Water quality and treatment. New York: Mc Graw Hill; 1971. p625-646.

O'Melia CR, Stumm W. Aggregation of silica dispersions by iron (III). $\mathbf{J}$ Coloid Sci. 1967; 23: 437-447.

Paganini WS. Disposição de esgoto no solo: escoamento à superfície. $2^{\mathrm{a}}$ ed. São Paulo: Fundo Editorial SABESP;1997. p. 19-29.

Pavanelli G, Eficiência dos diferentes tipos de coagulantes na coagulação, floculação e sedimentação de águas com cor ou turbidez elevada. São Carlos; 2001 [Dissertação de mestrado - Escola de Engenharia de São Carlos - USP].

Pearson et al. Water column sampling as a rapid and eficient method of determining efluent quality and the performance of waste stabilization ponds J Water Sci Technol 1987; 19 (12): 109-113.

Piveli, RP. Qualidade das águas. [Apostila] In: Universidade de São Paulo: Faculdade de Higiene e Saúde Pública, 1996.

Povinelli J; Campos JR. Coagulação e floculação In: Azevedo Netto JM. Técnica de abastecimento de água. $3^{\mathrm{a}}$ ed. São Paulo: CETESB/ASCETESB; 1986. v2. p. 91-130.

[PROSAB 3]. Programa de Pesquisa em Saneamento Básico 3. Tratamento de água para abastecimento por filtração direta. Rio de Janeiro: ABES; 2003.

Reali MAP. Principais características quantitativas e qualitativas do lodo de ETA's. In: Programa de Pesquisa em Saneamento Básico. Noções gerais de tratamento e disposição final de lodos de estações de tratamento de água. Rio de Janeiro: ABES; 1999 p. 21-39. 
Scalize PS. Disposição de resíduos gerados em estações de tratamento de água em estações de tratamento de esgoto. São Carlos; 2003 [Tese de doutorado - Escola de Engenharia de São Carlos - USP].

Scalize OS, Di Bemardo L, Carvalho EH. Disposição de resíduos líquidos de ETA's em ETE's. In: Programa de Pesquisa em Saneamento Básico. Noções gerais de tratamento e disposição final de lodos de estaçōes de tratamento de água. Rio de Janeiro: ABES; 1999 p. 169202.

Shreve RN, Brink Jr JA. Indústrias de processos químicos. Rio de Janeiro: Guanabara Dois; 1977.

Silva AS. On the treatment of domestic sewage in waste stabilization ponds in North East Brazil. Dundee; 1982 [ Phd thesis - University of Dundee, Scotland].

Sobrinho PA, Grandin SR, Garcia Jr AD. Desidratação de lodos produzidos em estações de tratamento de água. In: $17^{\circ}$ Congresso Brasileiro de Engenharia Sanitária e Ambiental; 1993 Set 19-23; Natal, Brasil. Rio de Janeiro ABES; 1993. p.324-343.

Stumm W; O'Melia CR. Stoichiometry of coagulation. J AWWA 1968; 514-539.

Teixeira LCGM. Adensamento por gravidade de lodos produzidos em estações de tratamento de água. São Paulo; 1999 [Dissertação de mestrado - Escola Politécnica da Universidade de São Paulo].

Tsutya MT, Hirata AY. Aproveitamento e disposição final do lodo das estações de tratamento de água do Estado de São Paulo. [CD Rom]. In: $21^{\circ}$ Congresso Brasileiro de Engenharia Sanitária e Ambiental; 2001 Set 16-21; João Pessoa, Brasil. Rio de Janeiro: ABES; 2001. 
Van Haandel A, Marais G. O comportamento do sistema de lodo ativado: teoria e aplicações para projeto e operações. Campina Grande: Universidade Federal da Paraíba, 1999:

Victoretti BA. Contribuição ao emprego de lagoas de estabilização como processo para depuração de esgotos domésticos. São Paulo; 1964. Tese de livre docência - Escola Politécnica da Universidade de São Paulo]

Von Sperling M. Introdução á qualidade das águas e ao tratamento de esgotos. $2^{\mathrm{a}}$ ed. Belo Horizonte : DESA-UFMG; $1996 \mathrm{v} 1$.

Von Sperling M. Lagoas de Estabilização. $2^{\mathrm{a}}$ ed Belo Horizonte: DESAUFMG; 1996 v 3.

Von Sperling M. Lodo de esgotos: tratamento e disposição final. Belo Horizonte: DESA-UFMG; 2001 v6, p.17-67

Yánez FC. Lagunas de estabilizacion - teoria, diseño, evaluacion y mantenimiento. Cuenca (Equador): Monsalve; 1993.

Yuzhu W. Condicionamento de lodo de estação de tratamento de água: estudo de caso. São Paulo; 1996. [Dissertação de mestrado Escola Politécnica da Universidade de São Paulo]. 
Caracterização das amostras do esgoto bruto e do efluente das lagoas anaeróbia e facultativa ( $1^{\mathrm{a}}$ Fase).

\begin{tabular}{|l|c|c|c|}
\hline Data & \multicolumn{3}{|c|}{$16 / 8 / 2004$} \\
\hline Pontos & 1 & 2 & 3 \\
\hline pH & 12 & 7 & 7 \\
\hline Temp. ar (o C) & 17 & 17 & 19 \\
\hline Temp. água (o C) & 18 & 18 & 19 \\
\hline DBO5d (mg/L) & 235 & 94 & 57 \\
\hline DBO5d filtrada(m g/L) & 121 & 42 & 56 \\
\hline DQO (m g/L) & 617 & 172 & 132 \\
\hline DQO filtrada(m g/L) & 253 & 162 & 120 \\
\hline NitrogênioTotal Kjedhal & nd & nd & nd \\
\hline Nitrogênio Amoniac. & nd & nd & nd \\
\hline Fósforo Total & nd & nd & nd \\
\hline Ortofosfato & nd & nd & nd \\
\hline ST (m g/L) & nd & nd & nd \\
\hline SF (m g/L) & nd & nd & nd \\
\hline SV (mg/L) & nd & nd & nd \\
\hline SST (m g/L) & nd & nd & nd \\
\hline SSF (m g/L) & nd & nd & nd \\
\hline SSV (m g/L) & nd & nd & nd \\
\hline Sólidos sedimentáveis & nd & nd & nd \\
\hline Ctotais & $3,00 E+08$ & $1,10 E+05$ & $5,00 E+05$ \\
\hline Cterm otolerantes & $5,30 E+06$ & $1,10 E+05$ & $2,20 E+05$ \\
\hline
\end{tabular}

\begin{tabular}{|l|c|c|c|}
\hline Data & \multicolumn{3}{|c|}{$30 / 8 / 2004$} \\
\hline Pontos & 1 & 2 & 3 \\
\hline pH & 7 & 7 & 7 \\
\hline Temp. ar (o C) & 19 & 19 & 19 \\
\hline Temp. água (o C) & 17 & 17 & 17 \\
\hline DBO5d (m g/L) & 251 & 75 & 54 \\
\hline DBO5d filtrada(m g/L) & 144 & 58 & 47 \\
\hline DQO (m g/L) & 516 & 331 & 227 \\
\hline DQO filtrada(m g/L) & 317 & 289 & 238 \\
\hline NitrogênioTotal Kjedhal & nd & nd & nd \\
\hline Nitrogénio Amoniac. & nd & nd & nd \\
\hline Fósforo Total & nd & nd & nd \\
\hline Ortofosfato & nd & nd & nd \\
\hline ST (m g/L) & 540 & 508 & 311 \\
\hline SF (m g/L) & 248 & 256 & 115 \\
\hline SV (m g/L) & 292 & 252 & 196 \\
\hline SST (mg/L) & 172 & 127 & 36 \\
\hline SSF (m g/L) & 31 & 17 & 4 \\
\hline SSV (m g/L) & 141 & 110 & 32 \\
\hline Sólidos sedimentáveis & nd & nd & nd \\
\hline Ctotais & $3,00 E+08$ & $1,30 E+06$ & $2,20 E+05$ \\
\hline Cterm otolerantes & $8,00 E+06$ & $2,30 E+05$ & $2,20 E+05$ \\
\hline
\end{tabular}


Caracterização das amostras do esgoto bruto e do efluente das lagoas anaeróbia e facultativa ( $1^{\mathrm{a}}$ Fase $)$.

\begin{tabular}{|l|c|c|c|}
\hline Data & \multicolumn{3}{|c|}{$13 / 9 / 2004$} \\
\hline Pontos & 1 & 2 & 3 \\
\hline pH & nd & 7 & 7 \\
\hline Temp. ar (o C) & nd & 22 & 22 \\
\hline Temp. água (o C) & nd & 20 & 20 \\
\hline DBO5d (m g/L) & nd & 68 & 44 \\
\hline DBO5d filtrada(m g/L) & nd & 52 & 40 \\
\hline DQO (m g/L) & nd & 221 & 131 \\
\hline DQO filtrada(m g/L) & nd & 121 & 120 \\
\hline NitrogênioTotal Kjedhal & nd & 18,2 & 21,3 \\
\hline Nitrogénio Amoniac. & nd & 13,9 & 7,4 \\
\hline Fósforo Total & nd & 6,88 & 8,08 \\
\hline Ortofosfato & nd & 4,68 & 3,5 \\
\hline ST (m g/L) & nd & 298 & 331 \\
\hline SF (m g/L) & nd & 163 & 183 \\
\hline SV (m g/L) & nd & 135 & 148 \\
\hline SST (mg/L) & nd & 20 & 64 \\
\hline SSF (m g/L) & nd & 2 & 6 \\
\hline SSV (mg/L) & nd & 18 & 58 \\
\hline Sólidos sedimentáveis & nd & nd & nd \\
\hline Ctotais & nd & $5,00 E+04$ & $1,10 E+04$ \\
\hline Ctermotolerantes & nd & $2,30 E+04$ & $9,00 E+03$ \\
\hline
\end{tabular}

\begin{tabular}{|l|c|c|c|}
\hline Data & \multicolumn{3}{|c|}{$27 / 9 / 2004$} \\
\hline Pontos & 1 & 2 & 3 \\
\hline pH & 6 & 7,5 & 7 \\
\hline Temp. ar (o C) & 21 & 20 & 22 \\
\hline Temp. água (o C) & 21 & 21 & 21 \\
\hline DBO5d (mg/L) & 452 & 47 & 29 \\
\hline DBO5d filtrada(m g/L) & nd & nd & 21 \\
\hline DQO (m g/L) & 1000 & 222 & 141 \\
\hline DQO filtrada(mg/L) & $n d$ & $n d$ & 60 \\
\hline NitrogénioTotal Kjedhal & 42,1 & 32 & 28,8 \\
\hline Nitrogénio Amoniac. & 32,7 & 22,7 & 21,9 \\
\hline Fósforo Total & 10 & 4 & 3,2 \\
\hline Ortofosfato & 6,1 & 3,5 & 2,8 \\
\hline ST (mg/L) & 1221 & 293 & 304 \\
\hline SF (mg/L) & 538 & 176 & 184 \\
\hline SV (mg/L) & 683 & 117 & 154 \\
\hline SST (m g/L) & 246 & 88 & 84 \\
\hline SSF (m g/L) & 84 & 65 & 67 \\
\hline SSV (mg/L) & 162 & 23 & 23 \\
\hline Sólidos sedimentáveis & nd & nd & nd \\
\hline Ctotais & $3,00 E+07$ & $1,70 E+06$ & $1,30 E+03$ \\
\hline Cterm otolerantes & $2,30 E+06$ & $8,00 E+04$ & $1,10 E+03$ \\
\hline
\end{tabular}


Caracterização das amostras do esgoto bruto e do efluente das lagoas anaeróbia $\theta$ facultativa $\left(1^{\mathrm{a}}\right.$ Fase $)$.

\begin{tabular}{|l|c|c|c|}
\hline Data & \multicolumn{3}{|c|}{$18 / 10 / 2004$} \\
\hline Pontos & 1 & 2 & 3 \\
\hline pH & 5,5 & 6 & 6,5 \\
\hline Temp. ar (o C) & 24 & 24 & 23 \\
\hline Temp. água (o C) & 23 & 23 & 23 \\
\hline DBO5d (m g/L) & 180 & 79 & 60 \\
\hline DBO5d filtrada(m g/L) & nd & nd & 20 \\
\hline DQO (m g/L) & 325 & 165 & 79 \\
\hline DQO filtrada(m g/L) & nd & nd & 67 \\
\hline NitrogénioTotal Kjedhal & 29,4 & 23,1 & 20,3 \\
\hline Nitrogénio Amoniac. & 25 & 17,4 & 20,7 \\
\hline Fósforo Total & 9 & 7,6 & 5,5 \\
\hline Ortofosfato & 3,39 & 2,98 & 2,7 \\
\hline ST (mg/L) & 418 & 366 & 371 \\
\hline SF (m g/L) & 201 & 181 & 206 \\
\hline SV (mg/L) & 217 & 185 & 165 \\
\hline SST (m g/L) & 195 & 67 & 122 \\
\hline SSF (m g/L) & 114 & 32 & 33 \\
\hline SSV (m g/L) & 81 & 35 & 89 \\
\hline Sólidos sedimentáveis & $<0,1$ & 1,5 & $<0,1$ \\
\hline Ctotais & $1,40 E+07$ & $1,80 E+05$ & $1,70 E+04$ \\
\hline Cterm otolerantes & $1,10 E+06$ & $2,80 E+04$ & $2,30 E+03$ \\
\hline
\end{tabular}

\begin{tabular}{|l|c|c|c|}
\hline Data & \multicolumn{3}{|c|}{$2 / 3 / 2005$} \\
\hline Pontos & 1 & 2 & 3 \\
\hline pH & 6 & 6,5 & 6 \\
\hline Temp. ar (o C) & 22 & 22 & 22 \\
\hline Temp. água (o C) & 21 & 21 & 21 \\
\hline DBO5d (m g/L) & 570 & 22 & 19 \\
\hline DBO5d filtrada(m g/L) & nd & nd & nd \\
\hline DQO (m g/L) & 881 & 116 & 57 \\
\hline DQO filtrada(m g/L) & 345 & 96 & 38 \\
\hline NitrogénioTotal Kjedhal & 32 & 27,2 & 24,7 \\
\hline Nitrogênio Amoniac. & 28,5 & 23,1 & 20 \\
\hline Fósforo Total & 8 & 5,6 & 4 \\
\hline Ortofosfato & 3,75 & 1,3 & 1,4 \\
\hline ST (m g/L) & 1016 & 240 & 233 \\
\hline SF (mg/L) & 455 & 143 & 147 \\
\hline SV (m g/L) & 561 & 97 & 86 \\
\hline SST (m g/L) & 165 & 42 & 42 \\
\hline SSF (m g/L) & 56 & 2 & 4 \\
\hline SSV (m g/L) & 109 & 40 & 38 \\
\hline Sólidos sedimentáveis & nd & nd & nd \\
\hline Ctotais & $2,60 E+07$ & $3,00 E+04$ & $2,60 E+03$ \\
\hline Cterm otolerantes & $2,00 E+06$ & $1,80 E+04$ & $1,40 E+03$ \\
\hline
\end{tabular}


Caracterização das amostras do esgoto bruto e do efluente das lagoas anaeróbia e facultativa ( $\left.1^{\mathrm{a}} \mathrm{Fas} \theta\right)$.

\begin{tabular}{|l|c|c|c|}
\hline Data & \multicolumn{3}{|c|}{$7 / 3 / 2005$} \\
\hline Pontos & 1 & 2 & 3 \\
\hline pH & 6 & 6,5 & 8,5 \\
\hline Temp. ar (o C) & 23 & 23 & 23 \\
\hline Temp. água (o C) & 23 & 23 & 23 \\
\hline DBO5d (m g/L) & 301 & 117 & 26 \\
\hline DBO5d filtrada(mg/L) & 148 & 18 & 9 \\
\hline DQO (mg/L) & 346 & 192 & 134 \\
\hline DQO filtrada(m g/L) & 288 & 96 & 38 \\
\hline NitrogénioTotal Kjedhal & 39,9 & 24,1 & 17,2 \\
\hline Nitrogénio Amoniac. & 30 & 15 & 13,7 \\
\hline Fósforo Total & 2,65 & 2,35 & 1,8 \\
\hline Ortofosfato & 2,05 & 1,5 & 0,5 \\
\hline ST (mg/L) & 667 & 225 & 316 \\
\hline SF (mg/L) & 317 & 144 & 153 \\
\hline SV (mg/L) & 350 & 81 & 163 \\
\hline SST (m g/L) & 320 & 40 & 114 \\
\hline SSF (mg/L) & 234 & 1 & 1 \\
\hline SSV (m g/L) & 86 & 39 & 113 \\
\hline Sólidos sedim entáveis & nd & nd & nd \\
\hline Ctotais & $1,60 E+07$ & $3,10 E+04$ & $2,30 E+04$ \\
\hline Ctermotolerantes & $1,10 E+07$ & $2,50 E+04$ & $1,80 E+03$ \\
\hline
\end{tabular}

\begin{tabular}{|l|c|c|c|}
\hline Data & \multicolumn{3}{|c|}{$14 / 3 / 2005$} \\
\hline Pontos & 1 & 2 & 3 \\
\hline pH & 6 & 7,5 & 8,5 \\
\hline Temp. ar (o C) & 24 & 24 & 24 \\
\hline Temp. água (o C) & 24 & 26 & 26 \\
\hline DBO5d (mg/L) & 279 & 22 & 14 \\
\hline DBO5d filtrada(m g/L) & 186 & 12 & 12 \\
\hline DQO (mg/L) & 654 & 218 & 182 \\
\hline DQO filtrada(mg/L) & 327 & 145 & 90 \\
\hline NitrogénioTotal Kjedhal & 70,7 & 52 & 35 \\
\hline Nitrogénio Amoniac. & 37,2 & 33 & 31 \\
\hline Fósforo Total & 5 & 2 & 2,2 \\
\hline Ortofosfato & 4,85 & 1,2 & 1,5 \\
\hline ST (mg/L) & 547 & 261 & 368 \\
\hline SF (mg/L) & 253 & 141 & 245 \\
\hline SV (mg/L) & 294 & 120 & 123 \\
\hline SST (mg/L) & 168 & 70 & 66 \\
\hline SSF (mg/L) & 44 & 0 & 2 \\
\hline SSV (mg/L) & 124 & 70 & 64 \\
\hline Sólidos sedimentáveis & 2,5 & $<0,1$ & $<0,1$ \\
\hline Ctotais & $3,00 E+07$ & $1,70 E+04$ & $1,30 E+04$ \\
\hline Ctermotolerantes & $1,30 E+07$ & $8,00 E+03$ & $1,30 E+03$ \\
\hline
\end{tabular}


Caracterização das amostras do esgoto bruto $\Theta$ do efluente das lagoas anaeróbia $\Theta$ facultativa ( $1^{\mathrm{a}}$ Fase).

\begin{tabular}{|l|c|c|c|}
\hline Data & \multicolumn{3}{|c|}{$21 / 3 / 2005$} \\
\hline Pontos & 1 & 2 & 3 \\
\hline pH & 7 & 7 & 10 \\
\hline Temp. ar (o C) & 26 & 26 & 26 \\
\hline Temp. água (o C) & 23 & 24 & 25 \\
\hline DBO5d (m g/L) & 225 & 17 & 15 \\
\hline DBO5d filtrada(m g/L) & 150 & 8 & 7 \\
\hline DQO (m g/L) & 739 & 259 & 222 \\
\hline DQO filtrada(m g/L) & 79 & 52 & 36 \\
\hline NitrogénioTotal Kjedhal & 25,5 & 14 & 10 \\
\hline Nitrogénio Amoniac. & 14,8 & 9 & 8 \\
\hline Fósforo Total & 6,2 & 5,5 & 3,5 \\
\hline Ortofosfato & 5,4 & 2,9 & 5,4 \\
\hline ST (m g/L) & 547 & 270 & 431 \\
\hline SF (mg/L) & 244 & 120 & 182 \\
\hline SV (m g/L) & 303 & 150 & 249 \\
\hline SST (m g/L) & 158 & 69 & 69 \\
\hline SSF (mg/L) & 30 & 2 & 6 \\
\hline SSV (m g/L) & 128 & 67 & 63 \\
\hline Sólidos sedim entáveis & 2 & $<0,1$ & $<0,1$ \\
\hline Ctotais & nd & nd & nd \\
\hline Ctermotolerantes & nd & nd & nd \\
\hline
\end{tabular}

\begin{tabular}{|l|c|c|c|}
\hline Data & \multicolumn{3}{|c|}{$28 / 3 / 2005$} \\
\hline Pontos & 1 & 2 & 3 \\
\hline pH & 5,5 & 6 & 6,5 \\
\hline Temp. ar (o C) & 20 & 20 & 20 \\
\hline Temp. água (o C) & 22 & 22 & 24 \\
\hline DBO5d (mg/L) & 225 & 20 & 18 \\
\hline DBO5d filtrada(mg/L) & 123 & 14 & 12 \\
\hline DQO (mg/L) & 500 & 100 & 40 \\
\hline DQO filtrada(mg/L) & 176 & 36 & 32 \\
\hline NitrogênioTotal Kjedhal & 56,4 & 32 & 38 \\
\hline Nitrogénio Amoniac. & 28,6 & 22 & 18 \\
\hline Fósforo Total & 4 & 2,3 & 1,9 \\
\hline Ortofosfato & $n d$ & 3,3 & 2 \\
\hline ST (mg/L) & 709 & 300 & 316 \\
\hline SF (mg/L) & 320 & 146 & 136 \\
\hline SV (mg/L) & 389 & 154 & 180 \\
\hline SST (mg/L) & 266 & 81 & 103 \\
\hline SSF (mg/L) & 58 & 8 & 5 \\
\hline SSV (m g/L) & 208 & 73 & 98 \\
\hline Sólidos sedimentáveis & 2,75 & $<0,1$ & $<0,1$ \\
\hline Ctotais & $3,00 E+07$ & $8,00 E+04$ & $7,00 E+04$ \\
\hline Ctermotolerantes & $1,70 E+07$ & $3,00 E+04$ & $1,70 E+04$ \\
\hline
\end{tabular}


Caracterização das amostras do esgoto bruto e do efluente das lagoas anaeróbia e facultativa ( $1^{\mathrm{a}}$ Fase $)$.

\begin{tabular}{|l|c|c|c|}
\hline Data & \multicolumn{3}{|c|}{$6 / 4 / 2005$} \\
\hline Pontos & 1 & 2 & 3 \\
\hline pH & 6 & 7 & 7,5 \\
\hline Temp. ar (o C) & 22 & 22 & 22 \\
\hline Temp. água (o C) & 23 & 25 & 25 \\
\hline DBO5d (m g/L) & 235 & 33 & 16 \\
\hline DBO5d filtrada(m g/L) & 173 & 12 & 7 \\
\hline DQO (m g/L) & 335 & 138 & 118 \\
\hline DQO filtrada(mg/L) & 216 & 79 & 39 \\
\hline NitrogénioTotal Kjedhal & 70,7 & 42 & 45 \\
\hline Nitrogenio Amoniac. & 26,432 & 20 & 16 \\
\hline Fósforo Total & 3 & 2 & 2 \\
\hline Ortofosfato & nd & 1,5 & 1,55 \\
\hline ST (mg/L) & 393 & 274 & 274 \\
\hline SF (mg/L) & 224 & 201 & 149 \\
\hline SV (mg/L) & 169 & 73 & 126 \\
\hline SST (mg/L) & 106 & 82 & 83 \\
\hline SSF (m g/L) & 34 & 7 & 14 \\
\hline SSV (m g/L) & 72 & 75 & 69 \\
\hline Sólidos sedimentáveis & 1 & $<0,1$ & $<0,1$ \\
\hline Ctotais & nd & nd & nd \\
\hline Ctermotolerantes & nd & nd & nd \\
\hline
\end{tabular}

\begin{tabular}{|l|c|c|c|}
\hline Data & \multicolumn{3}{|c|}{$11 / 4 / 2005$} \\
\hline Pontos & 1 & 2 & 3 \\
\hline pH & 6 & 8,5 & 9 \\
\hline Temp. ar (o C) & 23 & 23 & 23 \\
\hline Temp. água (o C) & 23 & 25 & 26 \\
\hline DBO5d (mg/L) & 225 & 12 & 9 \\
\hline DBO5d filtrada(mg/L) & 111 & 13 & 7 \\
\hline DQO (mg/L) & 577 & 173 & 135 \\
\hline DQO filtrada(mg/L) & 231 & $n d$ & $n d$ \\
\hline NitrogénioTotal Kjedhal & 53,2 & 26 & 32 \\
\hline Nitrogenio Amoniac. & 29,12 & 14 & 19 \\
\hline Fósforo Total & 4 & 3 & 3 \\
\hline Ortofosfato & 3 & 1,2 & 1,2 \\
\hline ST (mg/L) & 613 & 270 & 286 \\
\hline SF (mg/L) & 329 & 174 & 158 \\
\hline SV (mg/L) & 284 & 96 & 128 \\
\hline SST (mg/L) & 170 & 67 & 91 \\
\hline SSF (mg/L) & 63 & 10 & 27 \\
\hline SSV (mg/L) & 107 & 57 & 64 \\
\hline Sólidos sedimentáveis & 8 & $<0,1$ & $<0,1$ \\
\hline Ctotais & $5,00 E+07$ & $2,30 E+04$ & $5,00 E+02$ \\
\hline Ctermotolerantes & $1,10 E+07$ & $5,00 E+03$ & $3,00 E+02$ \\
\hline
\end{tabular}


Caracterização das amostras do esgoto bruto e do efluente das lagoas anaeróbia e facultativa ( $2^{\mathrm{a}}$ Fase).

\begin{tabular}{|l|c|c|c|}
\hline Data & \multicolumn{3}{|c|}{$25 / 4 / 2005$} \\
\hline Pontos & 1 & 2 & 3 \\
\hline pH & 6 & 7 & 6,5 \\
\hline Temp. ar (o C) & 23 & 23 & 23 \\
\hline Temp. água (o C) & 24 & 24 & 23 \\
\hline DBO5d (mg/L) & 258 & 51 & 23 \\
\hline DBO5d filtrada(m g/L) & 147 & 3 & 5 \\
\hline DQO (mg/L) & 369 & 129 & 111 \\
\hline DQO filtrada(mg/L) & 166 & 92 & 74 \\
\hline NitrogênioTotal Kjedhal & 42 & 33,5 & 25,2 \\
\hline Nitrogênio Amoniac. & 39,8 & 29,2 & 23,4 \\
\hline Fósforo Total & 7 & 2 & $n d$ \\
\hline Ortofosfato & 4,3 & 2 & 2 \\
\hline ST (mg/L) & 508 & 369 & 319 \\
\hline SF (mg/L) & 280 & 221 & 178 \\
\hline SV (mg/L) & 228 & 148 & 141 \\
\hline SST (mg/L) & 168 & 72 & 56 \\
\hline SSF (mg/L) & 61 & 16 & 5 \\
\hline SSV (mg/L) & 107 & 56 & 51 \\
\hline Sólidos sedimentáveis & 3,5 & $<0,1$ & $<0,1$ \\
\hline Ctotais & $8,00 E+07$ & $1,10 E+06$ & $2,30 E+04$ \\
\hline Ctermotolerantes & $8,00 E+06$ & $5,00 E+04$ & $1,30 E+04$ \\
\hline
\end{tabular}

\begin{tabular}{|l|c|c|c|}
\hline Data & \multicolumn{3}{|c|}{$2 / 5 / 2005$} \\
\hline Pontos & 1 & 2 & 3 \\
\hline pH & 6,5 & 7 & 7 \\
\hline Temp. ar (o C) & 19 & 19 & 19 \\
\hline Temp. água (o C) & 22 & 21 & 20 \\
\hline DBO5d (mg/L) & 301 & 28 & 27 \\
\hline DBO5d filtrada(mg/L) & 145 & 8 & 6 \\
\hline DQO (mg/L) & 607 & 257 & 202 \\
\hline DQO filtrada(m g/L) & 165 & 129 & 122 \\
\hline NitrogênioTotal Kjedhal & 58,8 & 51,3 & 42,7 \\
\hline Nitrogénio Amoniac. & 40,9 & 31,1 & 29,7 \\
\hline Fósforo Total & $n d$ & $n d$ & $n d$ \\
\hline Ortofosfato & 4,5 & 4,1 & 4 \\
\hline ST (mg/L) & 671 & 152 & 383 \\
\hline SF (mg/L) & 405 & 53 & 206 \\
\hline SV (mg/L) & 266 & 99 & 177 \\
\hline SST (m g/L) & 280 & 70 & 82 \\
\hline SSF (mg/L) & 113 & 11 & 11 \\
\hline SSV (mg/L) & 167 & 59 & 71 \\
\hline Sólidos sedim entáveis & 4,5 & $<0,1$ & $<0,1$ \\
\hline Ctotais & $2,20 E+07$ & $1,30 E+06$ & $3,00 E+04$ \\
\hline Ctermotolerantes & $1,10 E+07$ & $2,20 E+05$ & $2,30 E+04$ \\
\hline
\end{tabular}


Caracterização das amostras do esgoto bruto e do efluente das lagoas anaeróbia e facultativa ( $\left(2^{\mathrm{a}}\right.$ Fase $)$.

\begin{tabular}{|l|c|c|c|}
\hline Data & \multicolumn{3}{|c|}{$9 / 5 / 2005$} \\
\hline Pontos & 1 & 2 & 3 \\
\hline pH & 6,5 & 7,5 & 7,5 \\
\hline Temp. ar (o C) & 21 & 21 & 21 \\
\hline Temp. água (o C) & 20 & 20 & 19 \\
\hline DBO5d (mg/L) & 284 & 39 & 30 \\
\hline DBO5d filtrada(mg/L) & 113 & 8 & 8 \\
\hline DQO (mg/L) & 811 & 660 & 528 \\
\hline DQO filtrada(m g/L) & 528 & 189 & 170 \\
\hline NitrogénioTotal Kjedhal & 113,4 & 70 & 81,2 \\
\hline Nitrogénio Amoniac. & 35,8 & 27,2 & 23,9 \\
\hline Fósforo Total & 9 & 7 & 6,8 \\
\hline Ortofosfato & 4 & 2 & 2,3 \\
\hline ST (mg/L) & 634 & 394 & 376 \\
\hline SF (mg/L) & 404 & 224 & 240 \\
\hline SV (mg/L) & 230 & 170 & 136 \\
\hline SST (mg/L) & 220 & 87 & 74 \\
\hline SSF (mg/L) & 79 & 22 & 22 \\
\hline SSV (m g/L) & 141 & 65 & 52 \\
\hline Sólidos sedimentáveis & 6,5 & $<0,1$ & $<0,1$ \\
\hline Ctotais & $1,30 E+08$ & $3,00 E+05$ & $2,80 E+05$ \\
\hline Ctermotolerantes & $1,70 E+07$ & $1,40 E+05$ & $1,70 E+04$ \\
\hline
\end{tabular}

\begin{tabular}{|l|c|c|c|}
\hline Data & \multicolumn{3}{|c|}{$16 / 5 / 2005$} \\
\hline Pontos & 1 & 2 & 3 \\
\hline pH & 6,5 & 8 & 7,5 \\
\hline Temp. ar (o C) & 21 & 21 & 21 \\
\hline Temp. água (o C) & 20 & 20 & 20 \\
\hline DBO5d (mg/L) & 374 & 35 & 34 \\
\hline DBO5d filtrada(mg/L) & 70 & 10 & 8 \\
\hline DQO (mg/L) & 820 & 117 & 98 \\
\hline DQO filtrada(mg/L) & 469 & 55 & 39 \\
\hline NitrogénioTotal Kjedhal & 42 & 35,7 & 28,8 \\
\hline Nitrogénio Amoniac. & 29,5 & 24,7 & 21,1 \\
\hline Fósforo Total & 8,2 & 2,7 & 3,4 \\
\hline Ortofosfato & 6 & 1,1 & 1,2 \\
\hline ST (mg/L) & 1114 & 397 & 411 \\
\hline SF (mg/L) & 538 & 62 & 96 \\
\hline SV (mg/L) & 576 & 335 & 315 \\
\hline SST (mg/L) & 621 & 79 & 79 \\
\hline SSF (mg/L) & 253 & 7 & 10 \\
\hline SSV (mg/L) & 368 & 71 & 69 \\
\hline Sólidos sedimentáveis & 15 & $<0,1$ & $<0,1$ \\
\hline Ctotais & $8,00 E+07$ & $1,40 E+05$ & $5,00 E+04$ \\
\hline Ctermotolerantes & $1,10 E+07$ & $1,30 E+05$ & $5,00 E+04$ \\
\hline
\end{tabular}


Caracterização das amostras do esgoto bruto e do efluente das lagoas anaeróbia e facultativa ( $2^{\mathrm{a}}$ Fase).

\begin{tabular}{|l|c|c|c|}
\hline Data & \multicolumn{3}{|c|}{$30 / 5 / 2005$} \\
\hline Pontos & 1 & 2 & 3 \\
\hline pH & 6 & 7 & 7,5 \\
\hline Temp. ar (o C) & 22 & 22 & 22 \\
\hline Temp. água (o C) & 20 & 19 & 19 \\
\hline DBO5d (m g/L) & 189 & 42 & 35 \\
\hline DBO5d filtrada(mg/L) & 108 & 9 & 7 \\
\hline DQO (mg/L) & 378 & 140 & 101 \\
\hline DQO filtrada(mg/L) & 189 & 47 & 34 \\
\hline NitrogénioTotal Kjedhal & 39,2 & 15,4 & 14 \\
\hline Nitrogénio Amoniac. & 15,7 & 9,2 & 8,4 \\
\hline Fósforo Total & 6 & 4 & 3,5 \\
\hline Ortofosfato & 4 & 2 & 2 \\
\hline ST (mg/L) & 421 & 303 & 308 \\
\hline SF (mg/L) & 245 & 164 & 166 \\
\hline SV (mg/L) & 176 & 139 & 142 \\
\hline SST (mg/L) & 79 & 56 & 64 \\
\hline SSF (mg/L) & 27 & 11 & 9 \\
\hline SSV (mg/L) & 52 & 45 & 55 \\
\hline Sólidos sedimentáveis & 1,5 & $<0,1$ & $<0,1$ \\
\hline Ctotais & $8,00 E+07$ & $1,70 E+06$ & $7,00 E+05$ \\
\hline Ctermotolerantes & $3,00 E+07$ & $8,00 E+04$ & $3,00 E+04$ \\
\hline & & & \\
\hline & & & \\
\hline
\end{tabular}

\begin{tabular}{|l|c|c|c|}
\hline Data & \multicolumn{3}{|c|}{$13 / 6 / 2005$} \\
\hline Pontos & 1 & 2 & 3 \\
\hline pH & 6 & 6,5 & 7 \\
\hline Temp. ar (o C) & 21 & 21 & 21 \\
\hline Temp. água (o C) & 19 & 20 & 20 \\
\hline DBO5d (m g/L) & 259 & 49 & 35 \\
\hline DBO5d filtrada(mg/L) & 177 & 13 & 12 \\
\hline DQO (mg/L) & 350 & 122 & 91 \\
\hline DQO filtrada(mg/L) & 175 & 34 & 27 \\
\hline NitrogênioTotal Kjedhal & 67,2 & 42,6 & 44,5 \\
\hline Nitrogénio Amoniac. & 29,6 & 19,5 & 20,3 \\
\hline Fósforo Total & 6 & 3,8 & 3,5 \\
\hline Ortofosfato & 4,2 & 2,4 & 2 \\
\hline ST (mg/L) & 618 & 339 & 338 \\
\hline SF (mg/L) & 304 & 155 & 165 \\
\hline SV (mg/L) & 314 & 184 & 173 \\
\hline SST (mg/L) & 178 & 90 & 83 \\
\hline SSF (mg/L) & 74 & 8 & 7 \\
\hline SSV (mg/L) & 104 & 82 & 76 \\
\hline Sólidos sedimentáveis & 2,5 & $<0,1$ & $<0,1$ \\
\hline Ctotais & $2,30 E+07$ & $2,60 E+05$ & $2,20 E+05$ \\
\hline Ctermotolerantes & $1,30 E+07$ & $2,60 E+05$ & $2,20 E+05$ \\
\hline
\end{tabular}


Caracterização das amostras do esgoto bruto e do efluente das lagoas anaeróbia $\Theta$ facultativa ( $2^{\mathrm{a}}$ Fase).

\begin{tabular}{|l|c|c|c|}
\hline Data & \multicolumn{3}{|c|}{$27 / 6 / 2005$} \\
\hline Pontos & 1 & 2 & 3 \\
\hline pH & 7 & 6,5 & 6,5 \\
\hline Temp. ar (o C) & 17 & 17 & 17 \\
\hline Temp. água (o C) & 19 & 18 & 18 \\
\hline DBO5d (m g/L) & 361 & 71 & 38 \\
\hline DBO5d filtrada(mg/L) & 102 & 11 & 7 \\
\hline DQO (mg/L) & 496 & 184 & 148 \\
\hline DQO filtrada(mg/L) & 224 & 84 & 52 \\
\hline NitrogênioTotal Kjedhal & 36,4 & 20,2 & 15,1 \\
\hline Nitrogénio Amoniac. & 28 & 15,7 & 14 \\
\hline Fósforo Total & 4,1 & 2,3 & 2,3 \\
\hline Ortofosfato & 3,4 & 2 & 1,9 \\
\hline ST (mg/L) & 519 & 345 & 328 \\
\hline SF (mg/L) & 249 & 185 & 178 \\
\hline SV (mg/L) & 270 & 160 & 150 \\
\hline SST (mg/L) & 136 & 87 & 77 \\
\hline SSF (mg/L) & 31 & 9 & 12 \\
\hline SSV (mg/L) & 104 & 78 & 65 \\
\hline Sólidos sedimentáveis & 2 & $<0,1$ & $<0,1$ \\
\hline Ctotais & $1,70 E+07$ & $7,00 E+05$ & $2,80 E+05$ \\
\hline Ctermotolerantes & $5,00 E+06$ & $3,00 E+05$ & $8,00 E+04$ \\
\hline
\end{tabular}

\begin{tabular}{|l|c|c|c|}
\hline Data & \multicolumn{3}{|c|}{$4 / 7 / 2005$} \\
\hline Pontos & 1 & 2 & 3 \\
\hline pH & 7 & 6,5 & 6,5 \\
\hline Temp. ar (o C) & 17 & 17 & 17 \\
\hline Temp. água (o C) & 19 & 18 & 18 \\
\hline DBO5d (m g/L) & 301 & 50 & 38 \\
\hline DBO5d filtrada(mg/L) & 179 & 10 & 9 \\
\hline DQO (mg/L) & 414 & 128 & 95 \\
\hline DQO filtrada(m g/L) & 215 & 38 & 32 \\
\hline NitrogênioTotal Kjedhal & 61,6 & 52,4 & 50,6 \\
\hline Nitrogênio Amoniac. & 51,5 & 44,8 & 42,6 \\
\hline Fósforo Total & 5,8 & 3,4 & 2,7 \\
\hline Ortofosfato & 4,6 & 2,5 & 2,2 \\
\hline ST (mg/L) & 665 & 347 & 331 \\
\hline SF (mg/L) & 284 & 173 & 170 \\
\hline SV (mg/L) & 381 & 174 & 161 \\
\hline SST (m g/L) & 226 & 84 & 91 \\
\hline SSF (mg/L) & 51 & 10 & 8 \\
\hline SSV (m g/L) & 174 & 74 & 83 \\
\hline Sólidos sedimentáveis & 2 & $<0,1$ & $<0,1$ \\
\hline Ctotais & $1,70 E+07$ & $2,40 E+05$ & $1,10 E+05$ \\
\hline Ctermotolerantes & $8,00 E+06$ & $8,00 E+04$ & $8,00 E+04$ \\
\hline
\end{tabular}


Caracterização das amostras do esgoto bruto e do efluente das lagoas anaeróbia e facultativa ( $2^{\mathrm{a}}$ Fase).

\begin{tabular}{|l|c|c|c|}
\hline Data & \multicolumn{3}{|c|}{$11 / 7 / 2005$} \\
\hline Pontos & 1 & 2 & 3 \\
\hline pH & 7 & 6,5 & 6,5 \\
\hline Temp. ar (o C) & 16 & 16 & 16 \\
\hline Temp. água (o C) & 17 & 16 & 16 \\
\hline DBO5d (m g/L) & 331 & 48 & 38 \\
\hline DBO5d filtrada(m g/L) & 193 & 11 & 11 \\
\hline DQO (m g/L) & 450 & 133 & 129 \\
\hline DQO filtrada(m g/L) & 155 & 34 & 23 \\
\hline NitrogênioTotal Kjedhal & 53,8 & 42,5 & 37,7 \\
\hline Nitrogênio Amoniac. & 41,4 & 33,5 & 29,7 \\
\hline Fósforo Total & 5,5 & 2,9 & 2,7 \\
\hline Ortofosfato & 4,3 & 2,2 & 2,1 \\
\hline ST (m g/L) & nd & nd & nd \\
\hline SF (m g/L) & $n d$ & $n d$ & $n d$ \\
\hline SV (mg/L) & nd & nd & nd \\
\hline SST (mg/L) & 198 & 100 & 115 \\
\hline SSF (m g/L) & 44 & 32 & 43 \\
\hline SSV (mg/L) & 154 & 68 & 72 \\
\hline Sólidos sedimentáveis & 3 & $<0,1$ & $<0,1$ \\
\hline Ctotais & $3,00 E+07$ & $3,00 E+05$ & $1,70 E+05$ \\
\hline Ctermotolerantes & $1,30 E+07$ & $1,30 E+05$ & $1,70 E+04$ \\
\hline
\end{tabular}

\begin{tabular}{|l|c|c|c|}
\hline Data & \multicolumn{3}{|c|}{$18 / 7 / 2005$} \\
\hline Pontos & 1 & 2 & 3 \\
\hline pH & 6,5 & 7 & 6,5 \\
\hline Temp. ar (o C) & 15 & 15 & 15 \\
\hline Temp. água (o C) & 19 & 18 & 18 \\
\hline DBO5d (mg/L) & 340 & 58 & 28 \\
\hline DBO5d filtrada(m g/L) & 138 & 18 & 9 \\
\hline DQO (m g/L) & 475 & 336 & 180 \\
\hline DQO filtrada(m g/L) & 204 & 80 & 56 \\
\hline NitrogênioTotal Kjedhal & 52,4 & 41,7 & 36,8 \\
\hline Nitrogénio Amoniac. & 40,2 & 14 & 12,9 \\
\hline Fósforo Total & 5,8 & 3,2 & 2,8 \\
\hline Ortofosfato & 4,7 & 2,3 & 2 \\
\hline ST (mg/L) & $\mathrm{nd}$ & $\mathrm{nd}$ & $\mathrm{nd}$ \\
\hline SF (mg/L) & $\mathrm{nd}$ & $\mathrm{nd}$ & $\mathrm{nd}$ \\
\hline SV (m g/L) & $\mathrm{nd}$ & $\mathrm{nd}$ & $\mathrm{nd}$ \\
\hline SST (m g/L) & 200 & 140 & 78 \\
\hline SSF (mg/L) & 43 & 14 & 1 \\
\hline SSV (mg/L) & 157 & 126 & 77 \\
\hline Sólidos sedimentáveis & 4 & $<0,1$ & $<0,1$ \\
\hline Ctotais & $5,00 E+07$ & $3,00 E+05$ & $2,30 \mathrm{E}+05$ \\
\hline Ctermotolerantes & $1,30 \mathrm{E}+07$ & $1,30 \mathrm{E}+05$ & $5,00 \mathrm{E}+04$ \\
\hline
\end{tabular}


Caracterização das amostras do esgoto bruto e do efluente das lagoas anaeróbia e facultativa ( $2^{\mathrm{a}}$ Fase).

\begin{tabular}{|l|c|c|c|}
\hline Data & \multicolumn{3}{|c|}{$1 / 8 / 2005$} \\
\hline Pontos & 1 & 2 & 3 \\
\hline pH & 6,5 & 7 & 7 \\
\hline Temp. ar (o C) & 22 & 22 & 22 \\
\hline Temp. água (o C) & 20 & 21 & 21 \\
\hline DBO5d (mg/L) & 391 & 60 & 44 \\
\hline DBO5d filtrada(m g/L) & 147 & 22 & 14 \\
\hline DQO (mg/L) & 515 & 380 & 210 \\
\hline DQO filtrada(m g/L) & 274 & 92 & 75 \\
\hline NitrogénioTotal Kjedhal & 39,9 & 28 & 25,2 \\
\hline Nitrogénio Amoniac. & 33,6 & 18,2 & 23 \\
\hline Fósforo Total & 6,4 & 5,4 & 2,4 \\
\hline Ortofosfato & 5 & 2,1 & 1,5 \\
\hline ST (m g/L) & nd & nd & nd \\
\hline SF (mg/L) & nd & nd & nd \\
\hline SV (mg/L) & nd & nd & nd \\
\hline SST (mg/L) & 363 & 253 & 165 \\
\hline SSF (m g/L) & 93 & 30 & 35 \\
\hline SSV (m g/L) & 270 & 223 & 130 \\
\hline Sólidos sedimentáveis & nd & nd & nd \\
\hline Ctotais & nd & nd & nd \\
\hline Cterm otolerantes & nd & nd & nd \\
\hline
\end{tabular}

